\title{
WestVirginiaUniversity
}

THE RESEARCH REPOSITORY @ WVU

Graduate Theses, Dissertations, and Problem Reports

2015

\section{What Shadows We Pursue: Death, Democracy, and Disunion in Antebellum America}

Joseph M. Rizzo

Follow this and additional works at: https://researchrepository.wvu.edu/etd

\section{Recommended Citation}

Rizzo, Joseph M., "What Shadows We Pursue: Death, Democracy, and Disunion in Antebellum America" (2015). Graduate Theses, Dissertations, and Problem Reports. 6510.

https://researchrepository.wvu.edu/etd/6510

This Dissertation is protected by copyright and/or related rights. It has been brought to you by the The Research Repository @ WVU with permission from the rights-holder(s). You are free to use this Dissertation in any way that is permitted by the copyright and related rights legislation that applies to your use. For other uses you must obtain permission from the rights-holder(s) directly, unless additional rights are indicated by a Creative Commons license in the record and/ or on the work itself. This Dissertation has been accepted for inclusion in WVU Graduate Theses, Dissertations, and Problem Reports collection by an authorized administrator of The Research Repository @ WVU.

For more information, please contact researchrepository@mail.wvu.edu. 


\title{
What Shadows We Pursue: Death, Democracy, and Disunion in Antebellum America
}

\author{
Joseph M. Rizzo
}

\author{
Dissertation submitted to \\ the Eberly College of Arts \& Sciences \\ at West Virginia University \\ in partial fulfillment of the requirements \\ for the degree of
}
Doctor of Philosophy
of
History
Brian Luskey, Ph.D., Chair
Jason Phillips, Ph.D.
Ken Fones-Wolf, Ph.D.
Melissa Bingmann, Ph.D.
Aaron Sheehan-Dean, Ph.D

Department of History

Morgantown, West Virginia

2015

Keywords: Eulogy; Democracy; Memory; Political Culture

Copyright 2015 Joseph Rizzo 


\title{
ABSTRACT \\ What Shadows We Pursue: Death, Democracy, and Disunion in Antebellum America
}

\author{
Joseph M. Rizzo
}

This dissertation examines the ways Americans registered concerns about antebellum democratic political culture through their mourning of national leaders. A "eulogizing class" consisting of clergymen, politicians, lawyers, and educators was especially prominent in shaping how contemporaries remembered the dead. As a class, the eulogists were conflicted about democracy and partisanship, and conveyed their concerns through the potentially demagogic form of the eulogy — the practice of glorifying the "great man." Through an examination of eulogies, sermons, and newspaper editorials after the deaths of William Henry Harrison, Andrew Jackson, John Quincy Adams, John Calhoun, Henry Clay, and Daniel Webster, this dissertation reveals the tensions inherent in the cultural act of eulogy. Eulogists crafted a cultural narrative that promoted republican virtue and antidemocratic ideals and sought to convince their audiences - "the people" in democratic parlance - to reject a highly partisan democratic political culture. And yet, they realized that they could only communicate their antidemocratic beliefs through the means of democratic political culture, and their efforts illuminate how eulogists helped to shape democratic politics in antebellum America. Eulogists nostalgically looked backward to past political events in order to shape conversations about presidential elections and the political controversies of the day. During the secession crisis, Americans continued this trend, mourning the death of the nation by turning nostalgically toward the republican past as they sought the surest way to protect and promote their vision for the nation's future. However, eulogists mourning for the Union also showed greater acceptance of democracy and urged their listeners to act in virtuous ways. 


\section{ACKNOWLDGEMENTS}

I was cautioned when I began working on this dissertation that it could be a lonely and frustrating process. In many ways, that warning proved accurate. However, the last five years have shown me that no one can complete such a project without support from many people. This dissertation has benefited from a number of colleagues, friends, and family members who helped make its completion possible with their advice, patience, and encouragement. No words can fully convey my gratitude for all of those who helped in numerous ways.

This project started as a seminar paper in Dr. Brian Luskey's antebellum America course at West Virginia University in 2009. His advice and enthusiasm for the topic and my potential as a historian convinced me to stay at WVU for my doctorate. He has gone above and beyond the duties of an advisor while I have been in the program. I greatly appreciate his willingness to look over drafts or discuss the various challenges that emerged during the process, and I would not have been able to finish this project without his guidance. He helped this dissertation in immeasurable ways, with both refining its argument and improving its prose. I could not have asked for a better mentor throughout graduate school. I am also lucky to have had Dr. Melissa Bingmann's friendship and mentorship throughout my time in graduate school. Melissa's expertise and passion for public history has shaped me into the historian I am today. She is a terrific historian, mentor, and friend. Dr. Jason Phillips, Dr. Aaron Sheehan-Dean, and Dr. Ken FonesWolf have also brought their expertise to this project. Each showed interest in my research and a constant willingness assist with any of the challenges along the way. I am grateful to have had such a tremendous committee. 
I have had the privilege of meeting some great people during my time at WVU. Brandon Williams, Cara Snider, David Goldberg, and Lauren Thompson have helped me grow as a scholar and person in many ways. They have given me many great memories from my time in Morgantown and I am certain more to come in the future. Josh and Karina Esposito have also provided a tremendous amount of support. It would be hard to imagine surviving the rigors of the writing process without their friendship and frequent trips to Varsity Club. I would also like to thank Joel Christenson, Adam Zucconi, and Jake Ivey for always offering their assistance (and for discussing football). Sabre Wood provided much needed encouragement and support. Her faith in my ability to finish this project was a true inspiration. Jason and Lindsey Hedrick, Angie Sirna, and Jamie Blake also deserve recognition. I am lucky to have made such good friends during my time in Morgantown.

I am thankful to have had lifelong friends provide support while researching and writing. Russell Bermel, Philip Bermel, and John DeCarlo not only are incredible friends, but also offered places to stay while going on research trips over the last few years. Although Augie Lococo and Patrick Occhiuto have (admittedly) minimal knowledge of my research, they nonetheless deserve a great deal of credit for this dissertation. Whether through group messages or weekend trips to get away from writing, they provided me with much needed support. I am truly grateful to have so many great friends. Each has excelled in their respective careers and inspired me to do my best. I would also like to thank my friends at Manassas National Battlefield Park. Working at the park during the summers provided me with excellent experience as a public historian and introduced me to terrific friends and colleagues. In particular, I wish to thank and recognize Hank 
Elliott, Ray Brown, Mandie Sayers, Joe Phillips, and Mike Burns. I look forward to more bonfires at Quarters 9!

A family camping trip to Gettysburg sparked my interest in history. Little did Al and Jeanne Kick know that I would force them to take me back to Gettysburg multiple times. Despite having no interest in historic sites, my sister, Julie Lewis, went along (I am certain she complained at the time). Since then, she has provided helpful career advice and encouragement. Ralph and Joan Klicker have always shown interest in and been supportive of my education, and I appreciate their trips to visit me while in graduate school. Of course, I wish to thank my parents. From the beginning, they encouraged me to pursue the career I desired. From an early age, they instilled in me the value of hard work and the confidence to be successful at whatever I chose to study. I would not have made it through school without their love and support, and I would not be the person I am today without them. 


\section{Table of Contents}

Abstract...............................................................

Acknowledgements.................................................... iii

Chapter 1:

Introduction: "The Shadow of It Has Lain Heavily Upon the Land".................. 1

Chapter 2:

"It...Corrodes the Vitals of the Body Politic": Antipartyism and the Remembrance of

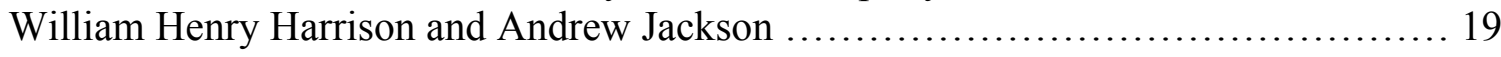

Chapter 3:

"Thought Governs, Not Numbers": Minority Rights and the Commemoration of John Quincy Adams and John C. Calhoun ...................................... 68

Chapter 4:

"The Last Has Been Gathered to the Tomb of His Fathers": The Memory of the Great Triumvirate and its Influence on 1850s Political Culture......................... 116

Chapter 5:

"The Blind See It, and the Deaf Hear It": Sermonizing Secession and the Threats to the Republic............................................................ 176

Chapter 6:

Conclusion:.......................................................... 222

Bibliography:......................................................... 229 


\section{Chapter 1:}

\section{Introduction}

\section{"The Shadow of It Has Lain Heavily Upon the Land"}

In November 1852, Roswell Hitchcock delivered a eulogy for Daniel Webster in front of the students of Bowdoin College. Webster's death was a terrible loss to the nation, Hitchcock lamented. But it was also a teaching moment: remembering Webster's legacy and service to the country was a valuable lesson for his young audience. "Human greatness, as an abstract conception, is not easily defined," asserted Hitchcock, but "truly great men, when they do actually appear, make their own way into history, and cannot fail to be recognized." Hitchcock compared Webster to heroes of the Revolution such as George Washington, Thomas Jefferson, and John Adams, and encouraged students to learn from the past in order to become virtuous republican citizens themselves. To Hitchcock, Webster represented the characteristics of what a republican statesman should be- a defender of liberty and the constitution who transcended the demagogic nature of democratic politics during the antebellum era. ${ }^{1}$ The ways Hitchcock brought Webster into the fold of "great men" who had made the nation highlighted the distinctions between “Godlike Daniel" and the current generation of political leaders. Hitchcock used his eulogy as an opportunity to extol Webster's statesmanship and nonpartisan credentials and condemn the political parties_-Democrats and Whigs - that had failed to inspire the American public during the recent presidential election. The loss of Webster defined the election, according to Hitchcock: "The shadow of it has lain heavily upon the land."

\footnotetext{
${ }^{1}$ Roswell D. Hitchcock, A Eulogy on Daniel Webster, Delivered Before the Students of Bowdoin College, on Friday, Nov. 12 $2^{\text {th }}, 1852$ (Brunswick: J. Griffin, 1852), 6-7.
} 
Hitchcock and his eulogy are representative of the eulogists' commemoration of national political leaders in the Early American Republic. In the period between 1840 and the Civil War, men of influence used their prominent positions in society to warn against the dangers threatening American politics and culture. In particular, a "eulogizing class" of clergymen, politicians, lawyers, writers, and educators displayed an antipathy to democracy and conveyed their concerns through the potentially demagogic form of the eulogy — the practice of glorifying the "great man." Hitchcock's social background and position resembled that of other eulogists: he was white, a graduate of Amherst College and Andover Theological Seminary, and was Professor of Religion at Bowdoin. His eulogy of Webster, like others in the genre, served as a vehicle to fight against the currents of an increasingly democratic political culture in which partisanship and egalitarianism, and not the disinterested republican virtue of powerful white men, ruled. ${ }^{2}$

And yet, in spite of their distrust of democracy, eulogists also helped to shape democratic political culture. This dissertation examines the ways that eulogists called "the people" into being, as pawns in their own efforts to establish power through a cultural narrative that registered their concerns with aspects of democracy and the apparent lessening of the importance of "great men." Even eulogists who held concerns about democracy took part in democratic culture by speaking to "the people" in order to convey their concerns. Democracy's dissenters often are overlooked in the making of democracy, yet through their orations they helped make American democracy. Between the Jacksonian era and the Civil War, eulogists participated in an unresolved struggle for American politics and culture. Eulogizing was an important political act during the antebellum era. Eulogists, not surprisingly, stressed that significance during their orations

\footnotetext{
${ }^{2}$ Ibid., 13.
} 
and connected their act of eulogy with the importance of eulogies to the ancient republics of Greece and Rome. ${ }^{3}$ Eulogists contended that their speech acts were crucially important in preserving the spirit of patriotism and republicanism in the nation. Historians have largely neglected the political significance of eulogies. As Mark Neely, Jr. observes in his study of Abraham Lincoln's eulogy on Henry Clay, eulogies tell more about the mourner than the mourned. He argues that eulogists revealed their broad national visions filtered through the lives of those they eulogized, and that their eulogies indicate what Americans most valued in their culture. ${ }^{4}$ Antebellum eulogies for dead political leaders illuminate the tensions with which their authors were grappling-how to condemn democratic political culture while also employing that culture's strategies and practices to reshape it. Eulogists considered themselves protectors of the republic and believed that their oratory fulfilled their duties as republican statesmen. They connected themselves not just to predecessors in ancient Greece and Rome, but also to other elite thinkers from the more recent past. A common connection made by eulogists was with Edmund Burke, the eighteenth century British orator and Whig politician. Burke's famous "Speech at Bristol Declining the Poll," delivered in 1780, received attention from American eulogists, since

\footnotetext{
${ }^{3}$ The connection between America's republic and the ancient republics of Greece and Rome was an important point of emphasis for eulogists. Up until the 1970s, historians generally disregarded the connection between the classics and the founding era. Historians Clinton Rossiter and Bernard Bailyn, for example, downplayed the influence. Following the rise of the New Left, however, more studies made the significant connection between the two. Gordon Wood, Joyce Appleby, Lance Banning, Caroline Winterer, and Meyer Reinhold have given valuable insight into this topic. In particular, Carl Richard's The Founders and the Classics: Greece, Rome, and the American Enlightenment, (Cambridge: Harvard University Press, 1994) and Caroline Winterer's The Culture of Classicism: Ancient Greece and Rome in American Intellectual Life 1780-1910 (Baltimore: Johns Hopkins University Press, 2002) have been helpful for understanding the importance of classics throughout the Early Republic.

${ }^{4}$ Mark E. Neely, Jr., "American Nationalism in the Image of Henry Clay: Abraham Lincoln's Eulogy on Henry Clay in Context," Register of the Kentucky Historical Society 73, 1 (January 1975), 31-34. The memory of a politician has important political ramifications beyond eulogies. For an example of a study that looks at the power of remembrance, see: Sarah Bischoff Paulus, "America's Long Eulogy for Compromise: Henry Clay and American Politics, 1854-1858," The Journal of the Civil War Era 4, (March 2014). While Neely examines eulogies of Clay, Paulus shows that the legacy and remembrance of deceased politicians has significant ramifications on politics and the conceptualization of past events.
} 
the speech partly served as a eulogy in addition to a political speech. Just before the first day's polling for elections at Bristol, Richard Combe, a candidate against Burke, died unexpectedly. During Burke's speech withdrawing from consideration, he touched upon Combe's life, lamenting that his death taught them "what shadows we are and what shadows we pursue. ${ }^{55}$ Eulogists throughout the antebellum era referenced Burke's words of eulogy. In a eulogy for John Quincy Adams, for example, Timothy Walker questioned the meaning of Burke's quotation for Adams's career. He stressed the importance of using Adams's life to teach citizens the characteristics of a "great man," and spent much of his eulogy touting Adams's nonpartisanship and his "republican simplicity." Walker, a distinguished lawyer from Ohio, graduated from Harvard and founded the Cincinnati Law School and the Western Law Review. ${ }^{6}$

The connection to Edmund Burke went beyond the quotation reiterated by several eulogists. The eulogizing class shared his incertitude about democracy. Throughout Burke's career, especially in the latter stages, he held an aversion for democracy and politics more generally. Although he held contempt for absolutism and supported constitutional principle, which of course had a democratic element, he nonetheless was skeptical of the usefulness of popular discussion and the opinions of the majority. ${ }^{7}$ The eulogizing class held similar concerns about democracy throughout the United States. Eulogists did not praise the increasingly egalitarian society for white men; rather, they were often conservative, antidemocratic memorialists of a republican past. Eulogists

\footnotetext{
${ }^{5}$ David Bromwich, The Intellectual Life of Edmund Burke: From the Sublime and Beautiful to American Independence (Cambridge: Harvard University Press, 2014), 445-446.

${ }^{6}$ Timothy Walker, An Oration on the Life and Character of John Quincy Adams: Delivered Before the Citizens of Cincinnati, On the Twenty-second day of March, 1848 (Cincinnati: J.F. Desilver, 1848), 19, 13.

${ }^{7}$ Bromwich, The Intellectual Life of Edmund Burke, 421-422.
} 
promoted a nostalgic interpretation of America's history that reaffirmed the need for great men and promoted their vision for the political culture.

This dissertation examines multiple forms of eulogy, including sermons and newspaper editorials. Orators delivering sermons or eulogies are termed "eulogists." Sermons are not always eulogies, but after the deaths of national leaders, clergymen delivered sermons on the deceased, which often took the form of a eulogy. Lawyers, politicians, and educators, often at the behest of an institution or committee, typically delivered traditional eulogies. Eulogies often maintained a consistent format despite the varied content within the eulogies depending on the particular orator. Eulogists usually began by explaining the importance of the act of eulogy for republics, and then touched upon the magnitude of the nation's loss. Eulogists chose particular aspects of the life and career of the deceased politician for their biographical sketches that fit into the narrative that they hoped to convey to their listeners. Eulogists intended to be adulatory since it would be in poor taste to criticize the deceased, yet their speeches nonetheless provided a platform for biting critiques about democratic political culture and became a vehicle for cultural persuasion. Eulogists could depict the culture they desired by evoking nostalgic memories of the past. ${ }^{8}$

Clergymen delivered sermons after the deaths of national politicians in which they focused on the career of the man and the lessons that congregants should heed.

\footnotetext{
${ }^{8}$ The power of memory is an important aspect of this dissertation. The memories created by eulogies influenced public perception of political events in the past, present, and future. In particular, this dissertation shows the ways that elite Americans during the antebellum era created memories in order to exert influence. It also shows the combativeness over memories during the era and the debates over memories and their meanings. A few studies in particular have helped shape this dissertation and its use of memory. For more on memory, see: Fitzhugh Brundage, ed. Where These Memories Grow: History, Memory, and Southern Identity (Chapel Hill: University of North Carolina Press, 2000); Michael Kammen, Mystic Chords of Memory: The Transformation of Tradition in American Culture (New York: Alfred A. Knopf, Inc., 1991); Alon Confino, "Collective Memory and Cultural History: Problems of Method," The American Historical Review 102, 5, (December 1997): 1386-1403.
} 
Clergymen often did not consider themselves eulogists when giving tribute to the deceased. They similarly saw the importance of their act, but they differentiated their sermons from political eulogies in order to appear more objective and apolitical. Ministers used sermons on national leaders to address contemporary political and cultural issues under the cloak of religious concern and nonpartisanship. Examining sermons delivered for deceased politicians also adds to our understanding of how religion and politics intertwined. Some historians contend that religious Americans avoided politics because of its secular and corrosive nature, yet this study supports other historians who argue that religious Americans were actively engaged in politics. Many religious citizens viewed their role in society through "Christian republicanism," which wedded Protestantism and republicanism throughout the mid-eighteenth century, and continued during the antebellum era leading evangelicals to let their faith shape public discourse. Christian republicanism, as explained by Mark Noll, had ambiguities that allowed Americans to place several republican and Christian ideals under "virtue" and to define the role of "the people" in republican institutions. Flexible republican and Christian loyalties accommodated varying attitudes toward democratic culture. ${ }^{9}$ Regardless of the denomination or region of the clergy, sermons provided a religious platform to speak of national sins and warn Americans of the political dangers threatening the nation unless democratic political culture was reformed. Clergy often claimed their sermons were not political in order to differentiate their act from the demagogic and partisan nature of politics that they censured. Clergymen, who claimed to be nonpartisans, used their sermons on dead politicians to speak to their congregants about political and partisan

\footnotetext{
${ }^{9}$ Mark A. Noll, America's God: From Jonathan Edwards to Abraham Lincoln (New York: Oxford University Press, 2002), 90-91.
} 
issues. ${ }^{10}$ Newspapers also eulogized deceased politicians, whether through republications of eulogies and sermons, or through editorials discussing the impact of the death on politics. While newspapers were fiercely partisan during the era, they nonetheless offered insight into the ways people chose to remember national leaders. They also provided a national forum to debate and discuss the content of eulogies. Newspapers democratized the inherently antidemocratic form of the eulogy by allowing for discussion and debate about the words of tribute. ${ }^{11}$

Historiographical developments over the last few decades have broadened the definition of politics and thus have made this type of historical analysis possible. Until the 1970s, political studies were typically confined to traditional approaches toward voting and debates among politicians inside the halls of Congress. Since then, however, the examination of "political culture" has led to a myriad of valuable studies that show the beliefs and attitudes that Americans and politicians held regarding politics. Examining newspapers, campaign paraphernalia, or petitions and rallies in which those ineligible vote participated, has broadened the definition of politics and expanded our understanding of what politics was to Americans throughout the antebellum era and the

\footnotetext{
${ }^{10}$ Noll, America's God, 73-92. Religion and politics heavily influenced each other during the antebellum period. For a pivotal study of the political influence of the evangelical movement, see: Richard J. Carwardine, Evangelicals and Politics in Antebellum America (Knoxville: The University of Tennessee Press, 1997). In understanding the role of religion on southern culture, this dissertation has been heavily influenced by: Mitchell Snay, Gospel of Disunion: Religion and Separatism in the Antebellum South (New York: Cambridge University Press, 1993). For a study on northern clergy, particularly during the Civil War, see: Sean A. Scott, A Visitation from God: Northern civilians Interpret the Civil War (New York: Oxford University Press, 2011). Another religious study that has influenced this dissertation is: Nathan O. Hatch, The Democratization of American Christianity (New Haven: Yale University Press, 1989). Many historians have used William Lloyd Garrison and his followers as an example of religious disengagement with politics. That has recently been challenged by W. Caleb McDaniel, who argues that Garrisonians defended democracy in a transatlantic region that still favored aristocracy. He contends that Garrisons in fact were politically savvy individuals. W. Caleb McDaniel, The Problem of Democracy in the Age of Slavery: Garrisonian Abolitionists \& Transatlantic Reform (Baton Rouge: Louisiana State University Press, 2013).

${ }^{11}$ On the role of newspapers before the Civil War, see: Jeffrey L. Pasley, "The Tyranny of Printers": Newspaper Politics and the Early American Republic (Charlottesville: University of Virginia Press, 2001).
} 
"evolving system of beliefs" that motivated citizens to participate politically in nontraditional ways. The use of political culture to examine American politics has framed my approach to studying the importance of eulogies delivered for national politicians. Through the supposedly innocuous form of eulogy, orators spoke openly about politics, elections, and the need for reform. The debates about democracy that occurred with the death of national leaders influenced elections. Contemporary political events also shaped how eulogists perceived the loss of a "great man," and often eulogists looked at the nation's republican past nostalgically, and used their orations to deliver screeds against the highly partisan and demagogic nature of politics. ${ }^{12}$

Members of the "eulogizing class" had varying societal visions and intentions in their eulogies, yet they had general similarities in how they perceived politics and what they wanted to advocate to their audiences. Eulogists were elite white men. While the increase in studies of political culture has enriched our understanding of the roles that women and minorities played in shaping political beliefs, elite white men still controlled the public space for official ceremonies eulogizing national leaders. The targeted

\footnotetext{
${ }^{12}$ The quotation for political culture comes from Daniel Walker Howe's study on the political culture of the Whig Party. His study has shaped this dissertation both in terms of defining "political culture" and for understanding the beliefs and motivations of the Whig Party. Daniel Walker Howe, The Political Culture of the American Whigs (Chicago: The University of Chicago Press, 1979), 2. Rachel Shelden's study of Washington D.C.'s social circles and the how lawmakers socialized with one another similarly sees Howe's definition of political culture as a framework and Shelden provides an excellent example of a study of the culture of politics. Rachel A. Shelden, "Washington Brotherhood: Friendship, Politics, and the Coming of the Civil War," Ph.D. diss., University of Virginia, 2011. For other examples that have been influential to this dissertation in understanding the study of political culture, see: Mark E. Neely, Jr., The Boundaries of American Political Culture in the Civil War Era (Chapel Hill: University of North Carolina Press, 2005); Ronald Formisano, The Transformation of American Political Culture: Massachusetts Parties, 1790s1840s (New York: Oxford University Press, 1983); Elizabeth Varon, Disunion! The Coming of the American Civil War 1789-1859 (Chapel Hill: University of North Carolina Press, 2008); David Waldstreicher, In the Midst of Perpetual Fetes: The Making of American Nationalism, 1776-1820 (Chapel Hill: University of North Carolina Press, 1997); Michael A. Morrison, Slavery and the American West: The Eclipse of Manifest Destiny and the Coming of the Civil War (Chapel Hill: University of North Carolina Press, 1997); Jean H. Baker, Affairs of Party: The Political Culture of Northern Democrats in the MidNineteenth Century (Ithaca: Cornell University Press, 1983); and Mary P. Ryan, Civic Wars: Democracy and Public Life in the American City during the Nineteenth Century (Berkeley: University of California Press, 1997).
} 
audiences of the eulogies also were typically elite and middle class citizens. The

rhetorical appeals to audiences showed concern about whether uneducated and lower

class Americans had the republican virtue to be active citizens in a democratic republic.

This dissertation examines cartoons, poems, and commemorations in addition to eulogies, and at times, those forms of political memory, which often contained ribald humor, targeted an audience that the eulogizing class detested. ${ }^{13}$

European observers travelling throughout the country noted the rise of American democracy, and many Americans lauded and eventually fought to protect that form of government. The democratization of American society during Andrew Jackson's presidency forever changed the United States and had ramifications beyond just the ballot box. ${ }^{14}$ While some hailed the movement toward a more egalitarian form of representative government, others looked at the changing culture of politics with skepticism and believed it was taking the nation down a path toward destruction. Many elite Americans

\footnotetext{
${ }^{13}$ Recent studies have provided an excellent look into the role of women in antebellum politics. For some examples, see: Lori D. Ginzberg, Untidy Origins: A Story of Woman's Rights in Antebellum New York (Chapel Hill: University of North Carolina Press, 2005); Elizabeth Varon, We Mean to Be Counted: White Women and Politics in Antebellum Virginia (Chapel Hill: University of North Carolina Press, 1996).

${ }^{14}$ For more on the rise of democracy during the Jacksonian Era, see: Sean Wilentz, The Rise of American Democracy: Jefferson to Lincoln (New York: W. W. Norton \& Company, 2005). For a collection of essays that cover issues of democracy and American Politics, see: Byron E. Shafer and Anthony J. Badger, eds., Contesting Democracy: Substance and Structure in American Political History, 1775-2000 (Lawrence: University of Kansas Press, 2001). In particular, essays by Ronald P. Formisano, David Waldstreicher, Joel Silbey, and Michael F. Holt are useful for understanding politics during the Early Republic and antebellum era. For a viewpoint questioning the idea of the nineteenth century being a "golden age" of participatory democracy, see: Glenn C. Altschuler and Stuart M. Blumin, Rude Republic: Americans and Their Politics in the Nineteenth Century (Princeton: Princeton University Press, 2000). On the paradox throughout the United States between democracy and the continued power of the "ruling class," see: Steve Fraser and Gary Gerstle, eds., Ruling America: A History of Wealth and Power in a Democracy (Cambridge: Harvard University Press, 2005). On concerns regarding issues of "pure democracy" during the antebellum era, see: Kyle G. Volk, "The Perils of 'Pure Democracy': Minority Rights, Liquor Politics, and Popular Sovereignty in Antebellum America," Journal of the Early Republic 29, (Winter, 2009), 641-679. On the issue of antislavery forces defending democracy within a slaveholding nation, see: McDaniel, The Problem of Democracy in the Age of Slavery.
} 
believed politics was degraded by political parties that employed electioneering tactics to trick the masses to cast uninformed votes. ${ }^{15}$

The eulogizing class, consisting of elite and college-educated men in respected positions, saw the rise of parties and the increased egalitarian nature of society as a threat to their authority and influence. In their orations for national leaders, they were able to eulogize one of their own - a man of education and republican virtue. Eulogists used the memories their orations made to speak of the need for Americans to rely on "great men" and warn about the nation's dangerous future unless great men again rise up to prevent the country from crumbling from within. Whether great men could rise up amid a democratic political culture remained a concern for eulogists. Indeed, through the secession crisis in 1861, eulogists could point to the impending crisis as a product of all that they had warned about throughout the previous two decades - partisanship, demagoguery, corruption, uniformed voters, and unqualified politicians jeopardized the republican nation that the Founding Fathers secured. While this dissertation does not directly focus on Civil War causation, it does continue a recent historiographical trend to move beyond the debate between fundamentalists and revisionists regarding whether the war was an irrepressible conflict over slavery or that other ethnocultural factors ushered in a war that was not inevitable. This dissertation examines the beliefs and ideas that citizens held about democracy, political parties, Union, slavery, republicanism, and

\footnotetext{
${ }^{15}$ This dissertation contends that antiparty spirit continued to pervade the political culture throughout the antebellum era. Historians typically believe that antiparty spirit waned by the Election of 1840. Ronald Formisano rightfully argues that antiparty spirit was still existent, as indicated by William Henry Harrison's Inaugural Address, but does not look at antipartyism into the 1840s. See: Ronald P. Formisano, "Political Character, Antipartyism and the Second Party System," American Quarterly 21, 4, (Winter, 1969): 683709. For more on antipartisanship in the North, in particular through the rise of the Know Nothing Party, see: Mark Voss-Hubbard, Beyond Party: Cultures of Antipartisanship in Northern Politics before the Civil War (Baltimore: Johns Hopkins University Press, 2002). On northern antipartyism, see: Baker, Affairs of Party, 108-140.
} 
nationalism, and how conflicts about these issues influenced perceptions about the secession crisis. Understanding the various definitions of democracy is critical for understanding why the Civil War occurred. ${ }^{16}$

Northern and southern eulogists shared many of the same values and ideals, even amid the sectional tensions during that antebellum era. Orations in both sections from 1841 to 1861 displayed a common antipathy toward political parties and democratic culture more broadly. Eulogists in both sections praised the idea of the "great man" and stressed the religious and political aspects of republicanism. ${ }^{17}$ While contemporary

\footnotetext{
${ }^{16}$ Edward Ayers has called for Civil War historians to move beyond the fundamentalist and revisionist interpretive camps. Elizabeth Varon echoes a similar sentiment and gives a detailed description of the differences between the two interpretive camps. Fundamentalists argue that slavery was the primary cause of disunion, and furthered the economic interpretation of disunion begun by Charles and Mary Beard that the war was inevitable due to the differences between northern and southern society. Historians like James M. McPherson, Eric Foner, Sean Wilentz, and John Ashworth have been leaders of this fundamentalist interpretation. Revisionists like Michael F. Holt, William E. Gienapp, and William H. Freehling have continued David Potter's argument that the North and South shared many of the same values. They argue that it was not just slavery that caused the Civil War and focus on intrasectional debates for explanation of why the Civil War happened when it did. Edward L. Ayers, What Caused the Civil War: Reflections on the South and Southern History (New York: W.W. Norton \& Company, 2005), 131-144; Elizabeth Varon, Disunion!: The Coming of the American Civil War, 1789-1859 (Chapel Hill: University of North Carolina Press, 2008), 14. For examples of Fundamentalist studies, see: James M. McPherson, Battle Cry of Freedom: The Civil War Era (New York: Oxford University Press, 1988); Eric Foner, Free Soil, Free Labor, Free Men: The Ideology of the Republican Party Before the Civil War (New York: Oxford University Press, 1970); Wilentz, The Rise of American Democracy; John Ashworth, Slavery, Capitalism, and Politics in the Antebellum Republic: Volume 2, The Coming of the Civil War 1850-1861 (New York: Cambridge University Press, 2007. For the earlier economic interpretation, see: Charles Beard and Mary Beard, The Rise of American Civilization (New York: Macmillan, 1927). For examples of revisionist studies, see: Michael F. Holt, The Political Crisis of the 1850s (New York: W.W. Norton \& Company, 1978); William E. Gienapp, The Origins of the Republican Party, 1852-1856 (New York: Oxford University Press, 1986); William W. Freehling, The Road to Disunion, Volume I: Secessionists at Bay, 1776-1854 (New York: Oxford University Press, 1990); William W. Freehling, The Road to Disunion, Volume II: Secessionists Triumphant (New York: Oxford University Press, 2007); David Potter, The Impending Crisis: 1848-1861 (New York: Harper and Row, 1976). There has been an abundance of scholarship examining various aspects of Civil War causation. For articles covering the vast historiography, see: Frank Towers, "Partisans, New History, and Modernization: The Historiography of the Civil War's Causes, 1861-2011," The Journal of the Civil War Era 1, (June 2011): 237-264; and Michael E. Woods, "What Twenty-First-Century Historians Have Said about he Causes of Disunion: A Civil War Sesquicentennial Review of Recent Literature," The Journal of American History 99, (September 2012): 415-439. For an excellent study of both the historiography of the secession crisis and of the crisis itself, see: Shearer Davis Bowman, At The Precipice: Americans North and South During the Secession Crisis (Chapel Hill: University of North Carolina Press, 2010).

${ }^{17}$ There are various definitions of republicanism and its use in studying political ideals during the era. Steven J. Ross, for example, argues that there was no single republican ideology, and that republicanism
} 
politics caused eulogists to voice concern, they similarly looked backward to the Founding generation's republican characteristics for guidance and examples of virtuous statesmen independent from political factions and not swayed by the whims of the masses. Divisions, however, largely came over the views of slavery, the meaning of the constitution, and the extent of antidemocratic thought. Slavery was inextricably linked with democracy. Defenders and critics of slavery advocated their positions through democratic means. Southern eulogists spoke out in unison over the dangers that democracy's majority rule meant for the South's social structure. Political parties and majority rule threatened the influence of elite white southern men and placed the institution of slavery at risk. Eulogists warned of these dangers in order to fight against the popular currents of democracy and to argue that the constitution was a proslavery compact of sovereign states created by the Founding Founders and sanctioned by God. Reverend James Henley Thornwell, for example, had considerable influence throughout the South and his sermons had a national audience. Thornwell, who was educated at South Carolina College, was influential both inside and outside of his Presbyterian church. He was a leading voice in a conservative and antidemocratic movement that sought to maintain the South's slave society and social hierarchy. He used his sermons after the death of John C. Calhoun and during the secession crisis to warn about the dangers of democracy to the South's vision for the Union. By 1861, he had become a

was a malleable series of beliefs and ideas. He contends that over time republicanism was interpreted, refashioned, and used by different classes and groups in different ways. See: Steven J. Ross, “The Transformation of Republican Ideology," Journal of the Early Republic 10, (1990): 324. Also see: Marc W. Kruman, "The Second American Party system and the Transformation of Revolutionary Republicanism," Journal of the Early Republic 12, (1992). 
leading southern nationalist, fearing that the northern democratic majority posed a grave threat to the South's society and to the constitution envisioned by the Founders. ${ }^{18}$

Northern eulogists shared many of the antidemocratic beliefs of their southern counterparts, though they differed on slavery's place in the nation's republican past and future. Northern eulogists were divided over slavery, and by the time of the secession crisis, conservative eulogists typically promoted sectional compromise and criticized northern antislavery factions as being a product of the hyper-partisan age that threatened the Union. Conservatives tried to return the nation to its republican heritage, thus obscuring slavery within democratic debate. Where northern and southern eulogists ultimately differed, however, was on conceptions of the Union and the surest way to secure the republican government they tried to protect. ${ }^{19}$ Of course, not all eulogists fit into an antidemocratic and conservative mold. Unitarian minister and activist Theodore Parker, for example, championed democracy and the abolitionist movement during his sermons. He used his sermon on Daniel Webster to criticize Webster's conservatism and acquiescence to proslavery interests. Through his sermons on deceased national politicians, though, he still spoke out against party factions and promoted his vision of the nation while looking backward to the revolutionary era for guidance. Throughout his public career, Parker was concerned that fellow northerners had lost their revolutionary spirit and his sermons after the deaths of John Quincy Adams and Daniel Webster were

\footnotetext{
${ }_{10}^{18}$ Snay, Gospel of Disunion, 83.

${ }^{19}$ Several excellent studies have examined the importance of Revolutionary ideology on the antebellum political culture. For more on that connection, see: Michael A. Morrison, Slavery and the American West: The Eclipse of Manifest Destiny and the Coming of the Civil War (Chapel Hill: University of North Carolina Press, 1997).
} 
attempts to reinvigorate northerners to take action and fight against forces trying to subvert the Revolution's legacy. ${ }^{20}$

Eulogists at times exuded the demagoguery against which they warned their listeners, and they used the strategies and means of democratic political culture even as they railed against it. Eulogists had a contradictory relationship with democracy. Conflicting ideologies espoused by eulogists like Thornwell and Parker, were emblematic of the tensions eulogists struggled with in their attempts to reshape democracy. Eulogists continuously framed their commemorations as declarations about democracy, about "the people," about political parties, and about democratic culture. While eulogists often used their commemorations to voice dissent about democratic culture, they nonetheless were critical voices in the making of democracy during the antebellum era.

This dissertation is organized chronologically and traces the perceptions of important political events through the orators' memories of particular deceased national leaders. While the deaths of revered politicians like George Washington, Thomas Jefferson, and John Adams caused an outpouring of public grief, I begin in 1841, with the death of William Henry Harrison and the period that is often viewed as the beginning of the two-party system's heyday. Chapter One examines the antiparty complexion of the political culture during the 1840s. The sermons and eulogies after Harrison's death highlight the pervasiveness of antipartyism in early 1840 s political culture. The problem of political parties, however, was also understood as a problem with democracy, and eulogists for Harrison used their orations to warn Americans about the dangers of political parties and of the corroded political system and its stunting of respectable

\footnotetext{
${ }^{20}$ Michael Fellman, "Theodore Parker and the Abolitionist Role in the 1850s," The Journal of American History 61, 3, (December 1974), 672-673.
} 
politics. Four years after Harrison's death, Democrats, whose party had most clearly shaped the political culture that Harrison's eulogists hated, nevertheless used similar antiparty rhetoric in their eulogies for Andrew Jackson. Democrats used such rhetoric in an attempt to absolve Jackson of his partisan career and to establish the Democratic Party as the party of "the people" that also carried on the republican tradition of the Founding generation.

The ways with which eulogists championed the advocates of minority rights in the antebellum era is the focus of Chapter Two. Orations following the deaths of John Quincy Adams and John C. Calhoun illuminated a complex political culture shaped by divisive issues of war, slavery, and territorial expansion. The orations for Adams and Calhoun demonstrated concern for the democratic political culture and the two-party system that seemed to produce demagoguery and a movement away from republican virtue. Calhoun's eulogists throughout South Carolina spoke steadfastly in antidemocratic language. Northern eulogists, however, illuminated a struggle over what constituted democracy in their eulogies for Adams. Orators for both Adams and Calhoun touted their republican virtue and defense of minority rights, yet offered contrasting visions over political ideology. While southerners used Calhoun's death to define slavery as a national institution and prepared their listeners for the possibility of disunion amid the Compromise of 1850, Adams's eulogists used his career to promote human rights and speak out against concessions to slaveholders that went against the tenets of republicanism.

Chapter Three looks at the influence the memories of Daniel Webster, Henry Clay, and John C. Calhoun - "The Great Triumvirate"- had on the political culture of the 
early 1850s. Eulogists for the Great Triumvirate cleansed Webster, Clay, and Calhoun of their faults and established them as nonpartisan national statesmen who sacrificed for the common good in order to do what was best for the nation. The nostalgic memories of the Great Triumvirate distorted accounts of the Nullification Crisis and the Compromise of 1850 and influenced perceptions of the future by raising concerns about whether democratic politics enabled statesmen to rise up amid a partisan and demagogic culture. The memories of a nostalgically crafted conservative past promoted in eulogies for Webster, Clay, and Calhoun in 1852 altered conceptualizations of current politicians who appeared to lack the virtue and manly characteristics of the Triumvirate. Doubt about current politicians made citizens skeptical of the ability of those politicians to guide the country during contentious events like the Kansas-Nebraska Act and destabilization of the party system.

The final chapter of this dissertation examines how eulogists, in particular ministers, adopted the language of mourning during fast day sermons to argue about democracy's influence in the secession crisis. Secession in many ways was the culmination of the fears, warnings, exultations, and ideals conveyed through the remembrance of national leaders and then ultimately of the Union during the previous two decades. Ministers in both sections used nationalism to promote their vision of the Union. ${ }^{21}$ Southern ministers commented on the dangers of democracy more than northern

\footnotetext{
${ }^{21}$ This dissertation's view of nationalism is influenced by Susan-Mary Grant's North over South: Northern Nationalism and American Identity in the Antebellum Era (Lawrence: University of Kansas Press, 2000), which argues that two alternative national ideologies emerged in the antebellum era, and that northern ideology was not necessarily "truly national" and that southern ideology was not "wholly sectional and destructive" (page 6). She also argues that northern nationalism formed as an expression of opposition against the South. Americans viewed Unionism similarly to nationalism. The study of nationalism by historians largely focuses around issues of disunion and the Civil War. On the use of nationalism as a historical tool, see: David Potter, "The Historian's Use of Nationalism and Vice Versa," American Historical Review 67, (1962), 924-950. Several excellent studies have influenced the analytical approach to
} 
ministers, who often obscured democracy altogether by focusing on issues of slavery, patriotism, and the constitution. Southern eulogists for the Union claimed in unison that the northern majority threatened proslavery republicanism and their belief that the United States was a slaveholding nation. Northern eulogists, particularly conservatives, shared many of those antidemocratic beliefs. Yet, the secession equated to anarchy to northern eulogists, who became reluctant democrats in order to prevent disunion and the breakdown of law and order.

This project utilizes the published eulogies and sermons that, at times, were widely circulated throughout the nation in pamphlet and book form. The publication and sale, as well as the debates over the content of the orations in newspapers were emblematic of the important act of eulogizing during the antebellum era. In a rapidly changing culture that was becoming increasingly more democratic, a "eulogizing class" of elite white orators spoke during times of national loss in an attempt to pigeonhole "the people" to fit within a cultural narrative that resisted threats to their authority. The eulogies illuminate the tensions the eulogizing class struggled with as they tried to reshape democratic political culture. The memories created throughout the eulogies influenced how citizens viewed legislation, politicians, and elections. The highly partisan democratic culture endangered the cherished traits of republicanism and the political order created by the founding generation. Eulogists helped make democracy with their orations that debated and defined it. The complex understanding of the changes wrought

nationalism throughout this dissertation. For a focus on northern nationalism, see: Earl J. Hess, Liberty, Virtue, and Progress: Northerners and their War for the Union (New York: Fordham University Press, 1997); Melinda Lawson, Patriot Fires: Forging a New American Nationalism in the Civil War North (Lawrence: University Press of Kansas, 2002). For issues of nationalism, particularly throughout the South, see: Paul Quigley, Shifting Grounds: Nationalism and the American South, 1848-1865 (New York: Oxford University Press, 2014). 
by democracy, detailed through the cultural act of eulogy, drove perceptions of political events and disunion as Americans sought the surest way to protect and promote their vision for the nation's future. 


\section{Chapter 2:}

\section{"It...Corrodes the Vitals of the Body Politic": Antipartyism and the Remembrance of William Henry Harrison and Andrew Jackson}

"For fifty-two years death was commanded to respect that chair," Presbyterian Pastor Ichabod Spencer asserted during a sermon in Brooklyn on the Sabbath following President William Henry Harrison's death. "The Lord God has begun to deal with us in a new way. We have little anticipated it." Since the country's founding, Americans believed that "Providence" had played a significant role in the creation and development of the Early Republic and had always, supposedly, respected the office of the presidency, allowing its occupants to retire from public office and depart the earthly world as private citizens. Never had American citizens experienced the death of a president while holding office. "The respect and affections of a grateful people followed their retiring magistrates to the walks of private life; and when, from time to time, their decease was announced, a nation put on the emblems of an unaffected sorrow," observed Spencer. Indeed, the country had mourned the loss of iconic figures before. George Washington's passing resulted in an outpouring of grief; the deaths of both Thomas Jefferson and John Adams on the jubilee of American independence suggested heavenly intervention and a blessing on the young republic. Following Harrison's death, however, the country had to come to terms with the calamity of losing a president just as he entered office. While the previously perceived signs from God bestowing His approval suggested exceptionalism, eulogists, in particular those of evangelical faith, tried to identify reasons for His 
condemnation. ${ }^{1}$

Eulogists viewed Harrison's passing as having greater significance than merely a coincidence of poor health; rather, it was a clear message from God that the country's sins needed correction. Sermons and eulogies delivered soon after his death illuminated the concerns of a eulogizing class over the subsequent social and political changes that occurred with the rise of democracy. National sins such as intemperance, antiSabbatarianism, economic greed, and "idolatry" of rulers received attention in the multitude of orations delivered soon after Harrison's passing. ${ }^{2}$ Most telling, however, was the moral urgency with which eulogists condemned party strife and debated the role of slavery in America. Eulogists used Harrison's passing in order to argue these national sins had spurred God's vengeance and left Him no choice but to take away the president whom many hoped would finally govern above the partisan fray. ${ }^{3}$

The sermons and eulogies for Harrison illuminated how apprehensive members of the eulogizing class had become. From their perspective, the demagogic and partisan political culture that democracy produced appeared to stunt respectable debate and corrode traditional republicanism. Harrison's death affirmed the sinful nature of the second party system that arose with Jacksonian democracy. The emergence of mass parties such as the Whigs and Democrats had infused electioneering tactics and political humbuggery into American political culture, and evangelical eulogists viewed this

\footnotetext{
${ }^{1}$ Ichabod S. Spencer, The National Warning: A Sermon, Preached on the Sabbath After the Death of General WM. H. Harrison, Late President of the United States (New York: John S. Taylor \& co., 1841), 910.

${ }^{2}$ William Sprague, Voice of the Rod: A Sermon, Delivered at Albany, May 14, 1841, The Day of the National Fast, Occasioned by the Death of the Late William Henry Harrison, President of the United States (Albany: C. Van Benthuyser, 1841), 14.

${ }^{3}$ Richard J. Carwardine, Evangelicals and Politics in Antebellum America (Knoxville: University of Tennessee Press, 1997), 68-69. Carwardine examined sermons after Harrison's death and argues for the important role that evangelical religion had on politics during the second party system. In his opinion, "Even more in death than in life was Harrison the herald of a new dawn" (page 70).
} 
development as a threat to the moral conscience of the country. ${ }^{4}$ Some members of the Whig Party and politicians who formed third parties tried to reshape a political system that fostered national sins by employing antiparty rhetoric. Even the second party system faced strong resistance from those who depended upon it. The concerns illuminated through the remembrance of Harrison continued into the mid-1840s with the rise of the Liberty Party, which combined antiparty sentiment with growing frustration about the conciliatory nature of the political parties regarding slavery.

A year after the Democratic Party regained the Executive Branch in the Election of 1844, its patriarch, Andrew Jackson, passed away at his home, the Hermitage. After his death, Democrats sought to soothe anxieties about the transforming political culture through the memory of Jackson by asserting that their partisan platforms - and leadersmost clearly represented "the people" and as a result were not partisan. In fact, the party best protected the nation's liberty. Since their party's formation, Democrats desired to convince voters that their values were in harmony with the country's republican ideals. Jackson's supporters compared his personal attributes to those held by the Founding Fathers and used his character to align the Democratic Party with America's republican roots and muffle anxiety over an increasingly partisan democratic culture created during Jackson's presidency. ${ }^{5}$ Lawyers, clergymen, military officials, and politicians eulogizing

\footnotetext{
${ }^{4}$ Michael Morrison, Slavery and the American West: The Eclipse of Manifest Destiny and the Coming of the Civil War (Chapel Hill: University of North Carolina Press, 1997). Morrison uses the term "humbug" to describe the feelings of Americans concerning late 1850s politics. During that time, P.T. Barnum popularized humbuggery and fraud; those sorts of sentiments were incorporated into the understanding of the political culture leading up to the Civil War.

${ }^{5}$ Richard Hofstadter's The Idea of a Party System examines antipartyism and the concept of American exceptionalism during the first party system. Hofstadter sees the period of 1797-1801 as being critical to the party system because of the peaceful transfer of power from the Federalists to the Republicans. Thomas Jefferson and the Republicans were effective in using antiparty sentiment to form a party that had a conciliatory response to the Federalists that helped weaken their base. Following Jefferson, James Monroe promoted antiparty or one-party sentiment by promoting American exceptionalism. This chapter argues
} 
Jackson found the tenets of republicanism useful in the hyper-partisan political culture of the 1840s. "While a nation bedews with tears the green turf where he sleeps, it is not sorrow without hope," argued Levi Woodbury, a friend of Jackson and Democratic politician. "For who can doubt that the same guardian power which has shielded us heretofore through the Washingtons and Jacksons, the Jeffersons and Franklins, that crowd the bright galaxy of our history, will raise up other worthies, and train them suitably to meet every peril which may menace us?" Rather than acknowledge Jackson's divisive personality that helped initiate the coming of the second party system, Woodbury's words of tribute placed Jackson above partisan squabbling and the perceived corruption of factions. By doing so, Jackson's death permitted Democrats to promote America's exceptionalism and the promising future of the country rather than politics or parties, while simultaneously advocating the Democracy as the guardian of the republic. In paying tribute to Jackson's manly characteristics, devotion to country, selflessness, and Christianity, eulogists attempted to shape the Democratic Party's image in the political culture through Jackson's death. While the newly formed Liberty Party and antislavery Whigs struggled to combat Democratic initiatives for territorial expansion in the mid1840 s, the Democrats, as the majority party, could exploit antiparty sentiment by exhibiting Jackson as a symbol of republicanism and the Democratic Party as the progeny of his patriotic efforts. ${ }^{7}$

that the Democratic Party similarly used such sentiment in the 1840s. See Richard Hofstadter, The Idea of a Party System: The Rise of Legitimate Opposition in the United States, 1780-1840 (Berkeley: University of California Press, 1969).

6 "Eulogy Delivered at Portsmouth, New Hampshire, July 2, 1845, by the Hon. Levi Woodbury, in B.M. Dusenbery, ed., Monument to the Memory of General Andrew Jackson (Philadelphia: Walker and Gillis, 1846), 85 .

${ }^{7}$ Connecting the Democratic Party to patriots of the past was not unique to Jackson's death. Jean H. Baker shows how Jackson and Martin Van Buren would attempt to link their party to those who first fought against the English and then opposed the Federalists. As in the eulogies of Jackson, Old Hickory and Little 
Rather than view parties as antagonistic to republicanism, Democrats promoted their party as the salvation of the republic. Scholarship on the antebellum era largely concludes that political organizations proved effective at soothing old republican fears that partisan politics would lead to despotism and corruption, and assumes that antiparty sentiment diminished with the emergence of the second American party system. ${ }^{8}$ Examination of the remembrance of national leaders, however, indicates that various approaches to republican antipartyism defined the political culture during the early 1840 s. Some sought the formation of third parties, like the Liberty Party, which condemned both parties on the issue of slavery. The nebulous nature of the Whig Party and the reasons why it should be viewed as an antiparty coalition are made plain through reactions to Harrison's death, as eulogists warned of national sins and lamented the loss of serious republicanism in politics. Conversely, ministers, politicians, and citizens more generally tried to obscure the party system during Jackson's passing to sustain Democratic dominance, portray American democracy as cohesive, and define it as the party of the Union that carried the mantel of the Founding generation, ultimately assisting it in pushing through the annexation of Texas, war with Mexico, and a divisive expansionist program.

For many, William Henry Harrison's candidacy represented an opportunity for the nation to move beyond the increasingly partisan style of government that arose in the 1830s. Although Whig politicos created an effective political machine to generate support

\footnotetext{
Van attempted to promote political parties by avoiding the contentious issues of political strife and promoting themselves as patriotic defenders of the nation. Jean H. Baker, Affairs of Party: The Political Culture of Northern Democrats in the Mid-Nineteenth Century (Ithaca: Cornell University Press, 1983), 112.

${ }^{8}$ Marc W. Kruman, "The Second American Party system and the Transformation of Revolutionary Republicanism," Journal of the Early Republic 12, (1992): 519-521.
} 
for Harrison and foment anger toward Van Buren, Harrison's supporters separated him from democratic culture and depicted him as being above this partisan fray. His lack of political experience, military record, speeches against partisanship, and promise to serve but one term convinced many Americans that he would govern above party platforms in a fashion similar to how George Washington was supposed to have governed during his presidency. The antiparty message delivered by Washington in his Farewell Address remained in public consciousness. His warnings of the dangerous and divisive tendencies of party strife resonated with a public still grounded in republican suspicions of political parties. ${ }^{9}$

Political satire before the 1840 election had tapped into strong sentiments for George Washington in order to demonstrate how current politicians competed with each other to claim his antiparty mantle for themselves. One 1836 cartoon places a statue of Washington on top of a mountain among the clouds, with Andrew Jackson as a snapping turtle descending the mountain. The cartoon also depicts Harrison as an eagle, flying above a snake (Van Buren), insinuating that Harrison was rising above the undesirable and disrespected figures and joining Washington (Figure 3). Cartoons such as this one represent more than mere support for Harrison. They connect Harrison to the memory of the Founding generation and to an era before organized political parties. Harrison “flying" above Democratic icons such as Jackson and Van Buren suggests Harrison's ability to be the second coming of Washington. ${ }^{10}$ These cartoons allude to the desire of Whig Party spokesmen to elect "a president of the nation, not a president of a party."

\footnotetext{
9 George Washington, "Farewell Address," in Messages and Papers of the Presidents, ed. James D. Richardson (20 vols., Washington, D.C., 1897-1917), I, 209-210.

10 "High Places in Government like Steep Rocks only Accessible to Eagles and Reptiles" (New York:

Published by H.R. Robinson, 1836).
} 
Doing so would not only be in tune with the interests of Whig constituents, but would also provide a stark contrast to Van Buren, whom many viewed as the architect of the party system. $^{11}$

The cartoon also has religious undertones, depicting the symbol of antiparty rhetoric, Washington, in a god-like fashion. In the late 1830s, evangelicals attempted to reshape the political arena by using practices and symbols that evoked the religious revivals of the Second Great Awakening. ${ }^{12}$ For many evangelicals throughout the North, the 1840 presidential election had a "profound religious significance," as Richard Carwardine argues. ${ }^{13}$ Increasing concern over unsavory aspects of democracy and the tactics employed by politicians caused evangelicals to turn to Harrison for political salvation from political strife. While some still rejected politics and viewed electioneering tactics as being antagonistic to serious republicanism, many others viewed Harrison's candidacy as an opportunity to save America's republic. This antiparty sentiment paradoxically led to evangelicals joining the Whig coalition and seeing Harrison as a religious symbol. Whigs skillfully used the emotional style of evangelical revivals to promote Harrison as the religious candidate and the Whig Party as the Christian Party. Abolitionist William Lloyd Garrison's condemnation of politics as inherently corrupt has led some historians to assume evangelicals did not participate in

\footnotetext{
${ }^{11}$ Major Wilson, "Republicanism and the Idea of Party in the Jacksonian Period," Journal of the Early Republic 8, (1988): 425. As Wilson notes on page 427, during the 1836 election Whigs warned that Van Buren was a despot who was handpicked by Jackson to be his successor, and that Van Buren would continue to govern for what was best for the party and not the country.

${ }^{12}$ Historians William Brock and Richard P. McCormick view the 1840 s as the decade when the presidential election, having incorporated much of the enthusiasm previously associated with the revivalism, came to supersede religion as the principal source of popular excitement. Richard Carwardine finds some truth in this argument, and came to that opinion by looking at the decrease of religious revivals and church growth. William R. Brock, Parties and Political Conscience: American Dilemmas 1840-1850 (Millwood: KTO press, 1979); Richard P. McCormick, The Second American Party System: Party Formation in the Jacksonian Era (Chapel Hill: University of North Carolina Press, 1966).

${ }^{13}$ Richard Carwardine, "Evangelicals, Whigs and the Election of William Henry Harrison," Journal of American Studies 17, (1983): 49.
} 
politics, but studying commemorations and other cultural acts of politics shows active evangelical engagement in the political arena. ${ }^{14}$

Despite running a "hard cider" campaign, Whigs portrayed Harrison as a model of sobriety, highlighted his Sabbatarianism, and even attempted to convince voters of "Old Tippecanoe's" supposed kindness to Indians. Campaign paraphernalia emblazoned the Whig campaign slogan "Harrison and Reform," which held religious connotations in addition to its secular meanings (Figure 1). ${ }^{15}$ Paraphernalia such as ribbons allowed for Whigs to incorporate religious symbols with emblems of Harrison's patriotism and military service. One particular campaign ribbon had the words "Our Country's Hope" with rays of light above Harrison's picture to potentially conjure heavenly projections, along with a $\log$ cabin below Harrison's picture to evoke the motto "Log Cabin and Hard Cider." These emblems signify the Whigs' ability to incorporate religious and antiparty sentiments with their campaign strategy of relating to the common man in the wake of the Panic of $1837 .{ }^{16}$ This allowed evangelicals to go to the polls believing that a vote for the Whig Party was not an endorsement of the two-party system; rather, they viewed their vote as a fulfillment of their duties as "Christian patriots" and an effort to restore religion to their republican government. ${ }^{17}$

Harrison, in his inaugural address, gave further proof of his vision to bring religion into government and rise above the partisan strife. He referenced Providence's

\footnotetext{
${ }^{14}$ W. Caleb McDaniel argues Garrisonian abolitionists preached that dissent was a critical component to the making of democracy in the United States. For more on the relationship between abolitionism and democracy, see: W. Caleb McDaniel, The Problem of Democracy in the Age of Slavery: Garrisonian Abolitionists \& Transatlantic Reform (Baton Rouge: Louisiana State University Press, 2013).

${ }^{15}$ Ronald P. Formisano, The Birth of Mass Political Parties: Michigan 1827-1861 (Princeton: Princeton University Press, 1971), 129-131; Carwardine, "Evangelicals, Whigs and the Election of William Henry Harrison," 64.

16 "Our Country's Hope," (Baltimore: J.S. Horton, 1840).

${ }^{17}$ Richard J. Carwardine, Evangelicals and Politics in Antebellum America (Knoxville: University of Tennessee Press, 1997), 57-58.
} 
role in society and government, and he was the first president to acknowledge the "Beneficent Creator" in an inaugural address since George Washington did so. ${ }^{18}$ Evangelicals had their belief in Harrison's piety reinforced by his recognition of God. As Ron Formisano observes, Harrison's speech also displayed the vitality and breadth of antiparty sentiment throughout the country. Harrison warned of the dangers of party strife and how it could become destructive to public virtue. Though Formisano sees antiparty spirit beginning to wane by the 1840 s, events one month into Harrison's presidency showed how deeply antiparty spirit ran through sections of the country. ${ }^{19}$ Many eulogists considered Harrison's death, one month after delivering an inaugural address that supposedly began a new era of American republicanism, as a fearful omen for the country. Following the president's unexpected passing, men of the cloth across the North mourned his loss, yet also perceived his death to be a clear message from God regarding the national sins of the country. "Never before, since the first organization of our government, has He spoken to us, as a nation, so emphatically," observed Horatio Potter, an Episcopalian priest speaking in front of the New York legislature. ${ }^{20}$ Ministers hoped that congregants who listened and citizens who read their words would heed God's warning and proactively try to correct these sins. ${ }^{21}$

\footnotetext{
18 “The Inaugural Address: Of gen. William Henry Harrison, March 4, 1841," Niles' National Register, March 6, 1841.

19 “The Inaugural Address: Of Gen. William Henry Harrison, March 4, 1841," Niles' National Register; Ronald P. Formisano, "Political Character, Antipartyism, and the Second Party System," American Quarterly 21, (1969): 686.

${ }^{20}$ Horatio Potter, A Discourse on the Death of William Henry Harrison, Late President of the United States; Delivered Before the two Houses of the Legislature of the State of New-York, On the $25^{\text {th }}$ Day of April, 1841 (Albany, New York, 1841), 19.

${ }^{21}$ For similar sentiments, see: George Putnam, A Discourse, On the Occasion of the Death of William Henry Harrison, Ninth President of the United States: Delivered at Roxbury, April 16, 1841 (Boston: William Crosby and co., 1841), 25-27. Throughout his sermon, Putnam warned of the negative aspects of political parties within politics. The deception, pageantry, and songs "appealed to the highest interests and to the lowest motives," and distracted Americans from their Christian duties to their government by making
} 
Many northern evangelicals found themselves supporting the Whig Party in spite of the unpleasant attributes of some party leaders. Although the Whigs grew out of opposition to Andrew Jackson's supposed tyrannical presidency, the Whig Party evolved into more than merely a Party of opposition. ${ }^{22}$ Whigs took strong stands for Clay's American System, a national bank, and higher tariffs, but the Whigs lacked the party foundation and patronage system that made the Democrats the majority party in the antebellum period. For many Whigs — and evangelical Whigs in particular-ideology came before party. Historian Daniel Walker Howe correctly argues that the Whigs should be studied as a culture rather than just as a party, because the culture was more powerful than the party itself. The Whigs emphasized a broad scope of social issues and their supporters used the party as a vehicle to voice frustration with the demagoguery and partisanship that seemed to define democratic political culture. ${ }^{23}$

The Second Great Awakening played a significant role in the formation of northern Whiggery, and in many local governments, there were connections between the Whig Party and the evangelical movement. ${ }^{24}$ With evangelicals, anti-masons, and antiJacksonians coming together under the Whig banner, strong antiparty sentiment ran through the party from its origins until its dissolution. The strong ideological foundations within northern Whiggery meant that Whigs, unlike Democrats, did not regard party

\footnotetext{
them more concerned with partisan politics, he asserted. In his opinion, the fate of the country depended on it doing so and adhering to these instructions from Providence.

${ }^{22}$ Daniel Walker Howe, "The Evangelical Movement and Political Culture during the Second Party System," Journal of American History 77, (1991): 1233; for more on the history of the American Whig Party, see: Michael F. Holt, The Rise and Fall of the American Whig Party: Jacksonian Politics and the Onset of the Civil War (New York: Oxford University Press, 1999).

${ }^{23}$ Daniel Walker Howe, The Political Culture of the American Whigs (Chicago: The University of Chicago Press, 1979), 3.

${ }^{24}$ Paul E. Johnson, A Shopkeeper's Millennium: Society and Revivals in Rochester, New York, 1815-1837 (New York: Hill and Wang, 1978). Johnson studied the religious revivals in Rochester and saw a close connection between evangelicals and the Whig Party in the city. According to Johnson, the rise of the Whig Party became a vehicle for promoting legislation against sinful behavior.
} 
loyalty as a supreme virtue. In this regard, the Whig Party should be viewed as an antiparty coalition just as much as a culture or party. The combative and sometimes contradictory attitudes about political parties are indicative of the tensions at the heart of democratic political culture. The Antiparty faction within the Whigs condemned aspects of the political culture even as they sought power through it. ${ }^{25}$

Eulogists understood the religious and political significance of the words they spoke. In particular, Whigs tended to place great emphasis on orations and orators. As Howe suggests, orators during this era felt compelled to guide "the people" in understanding their own interests. Although Southern Baptist Minister William Crane viewed himself as nonpartisan he believed the pulpit could give greater meaning to political and national events. "As a minister and a Christian," asserted Crane, "I trust I shall never desecrate my office by an association of the mere demagogue with the care of a flock who are all equally the objects of attention and solitude." Crane believed he had a religious and political responsibility to explain that Harrison was not a mere party officer- he was the president of and for the people of the country, and his death was a time of mourning for all. Crane's words are characteristic of many eulogists who viewed themselves as being above the demagoguery they railed against. The act of delivering a sermon gave them a literal and figurative pulpit in which they could speak of political issues while appearing apolitical. Often, eulogists attempted to rise above demagoguery through the act of demagoguery. ${ }^{26}$

Sermons delivered in the weeks following Harrison's death reverberated

\footnotetext{
${ }^{25}$ Formisano, "Political Character, Antipartyism, and the Second Party System," 684, 700.

${ }^{26}$ William Carey Crane, A Discourse Occasioned by the Death of William Henry Harrison President of the United States, delivered May 2, 1841, in the Baptist Church (Montgomery: Montgomery Advertiser, 1841), 5.
} 
strikingly similar warnings and condemnations about national sins. The ability to raise these concerns afforded itself after President John Tyler called for a "day of Fasting and Prayer" on May 14 in honor of Harrison. ${ }^{27}$ This national day of fast allowed eulogists to bring attention to God's judgment and to show the important role evangelicals must have in saving their heavenly ordained republic. Reverend Jacob Douglass of Philadelphia echoed concerns about the negative influence that the electioneering tactics of political parties posed. "By the death of President Harrison, the Lord rebukes the exacerbations of party spirit," he warned. In Douglass's opinion, the party spirit was degrading, injurious, and corroded republican institutions. "It is like the canker-worm. It frets and gnaws and corrodes the vitals of the body politic," he lamented. No longer were politics and political debate respectful. The partisanship and exaggerations of the parties led to maliciousness and the disrespect of political leaders' private lives. ${ }^{28}$

The fierce partisanship of democratic culture that appeared to erode respectable politics created a tenuous relationship between evangelicals and politics. The sermons after Harrison's death, however, indicate a strong desire by evangelicals to have an active role in democracy and help return Christianity into public institutions. Ministers contended that it was God's message, not individual desires in politics, which gave them justification for entering into the political arena. The New Hampshire Sentinel reprinted an extract of the sermon by antislavery Reverend Heman Humphrey, President of Amherst College, in which he displayed concerns over discussing political matters at the

\footnotetext{
27 “Official. To the People of the United States. A Recommendation," Portsmouth Journal of Literature and Politics, April 17, 1841.

${ }^{28}$ Jacob M. Douglass, A Discourse on the Death of General Harrison, Late President of the United States, Preached in St. Mathews Church, Francisville, Philadelphia, on Sunday, $18^{\text {th }}$ April 1841 (Philadelphia: printed by H. Probasco, 1841), 8. For similar sentiments against partisanship and "recklessness of party violence," see: John C. Rudd, Forgetfulness of God: A Sermon, Preached in Trinity Church Utica, on Friday, May 14, 1841, Being the Day Recommended by the President of the United States, as a Day of National Humiliation and Prayer (Utica: Horbart Press, 1841), 14-15.
} 
pulpit. "You have, my friends, known my manner of life," stated Humphrey, who maintained he did not get involved with politics publicly, but that "as a patriot, a lover, of my country, I have never been indifferent to the character and policy of our public men." Although he claimed to avoid publicly discussing political matters, he did precisely that. Harrison's Sabbatarianism and inaugural address showed that it was possible for Christianity to play an active part in shaping the American political process. ${ }^{29}$ For Democrat and Dutch Reformed Church pastor George Bethune, a graduate from Dickinson College and Princeton University, the nation needed to move past partisan squabbling, create an environment for honest men to debate, and discuss issues without bitterness and "sneering suspicion.” God's message through Harrison's death called for an end to this resentful style of politics that arose from democratic culture. Bethune saw it as his duty to God and to his country to speak out against the current political environment and put the country past petty partisanship. ${ }^{30}$

By the 1840 s, many evangelicals who allegedly rejected political participation because of partisan strife were more willing to engage in democratic political culture to correct national and individual sins in order to make the country worthy of God's eventual earthly return. To educator and Reverend Benjamin Labaree, President of Middlebury College, those who had the ability to vote had a responsibility to "engage in

\footnotetext{
29 "Discourse on the Death of President Harrison, delivered on the morning of the Annual State Fast by Heman Humphrey, D.D., President of Amherst College," New-Hampshire Sentinel, April 28, 1841. 30 "A Discourse on the Death of William Henry Harrison, Late President of the United States" The New World, May 1, 1841. For more on the life of George W. Bethune, see: Alexander Ramsay Thompson, $A$ Tribute to the Memory of the Rev. George W. Bethune, D.D., Pastor of the Reformed Dutch Church, Twenty-First Street, New-York (Cambridge: Harvard University Press, 1882). For similar sentiments on Christians having an active roll in politics, see: Douglass, A Discourse on the Death of General Harrison, 4; Alexander T. McGill, The Presence of God a People's Prosperity: A Sermon Preached on Sunday Morning, April 11, 1841, in the Presbyterian Church, at Carlisle, PA (Philadelphia: William S. Martin, 1841), 6-7.
} 
the work." ${ }^{31}$ The country needed to understand the message Providence sent by taking Harrison from the nation. Labaree noted that Harrison's death was a warning to calm the "angry surges of political strife," and to teach them "“what shadows we are, and what shadows we pursue." ${ }^{32}$ Voting became a way to purify democracy with Christian conscience. Labaree called for voters to let their consciences inform their decisions at the ballot box. "How many now feel constrained to vote for men whose character they cannot approve, merely by the force of party dictation," asked Labaree. "Of all the tyrants, that have warred against personal liberty, he concluded, "none is more relentless and unappeasable than party." Larabee urged for a reform of democratic political culture by diminishing the role of political parties. He asserted that America's founding showed divine blessing and enforced beliefs about the virtues of republicanism. In order for God's blessing of the country to reemerge, citizens had to "break their manacles, emancipate themselves from political masters, and prove themselves the noble sons of those noble sires" who governed for the good of the country and not for a particular political party. ${ }^{33}$ The dependency on and deferment to political parties was akin to slavery in the minds of some northern eulogists. They called for active engagement in democratic politics to break the figurative chains of sin. Evangelical democratic participation is indicative of the tension within democracy during the antebellum era. Many evangelicals were not democrats, and at times they acted as demagogues, but they encouraged active democratic participation to reform democracy. This resistance and the contradictory

\footnotetext{
${ }^{31}$ Benjamin Labaree, A Sermon on the Death of General Harrison, Delivered in Middlebury, Vermont, on the Day of the National Fast (Middlebury: E. Maxham, 1841), 26.

${ }^{32}$ Ibid., 5 .

${ }^{33}$ Ibid., 26, 27.
} 
response over democratic political culture helped make American democracy. ${ }^{34}$

The commemoration of national leaders provided a teachable moment against the characteristics of democratic culture that could lead to other forms of corruption. Some observers worried that migration to cities would give demagogues greater ability to deceive young men. ${ }^{35}$ Urban growth led to prosperity for some, but it also opened avenues for sin and convinced concerned citizens of the need to use the Founding Fathers as beacons of morality, respectability, and republican virtue. ${ }^{36}$ University of Vermont President Reverend John Wheeler highlighted those concerns, trusting "that in the coming years men shall arise to bless the nation with a clearness of intellectual vision and a depth of conscientious feeling, which shall make them safe guards, not to a party, but to the nation." America's future depended on the rising generation avoiding selfish temptations and not falling victim to acts of pageantry and deception. The stability of the country's social and political order — threatened by urban capitalism and democracywould come through "the people" putting aside party bickering and animosity and humbling themselves to God. The ability to do so relied on restoring the honorable and

\footnotetext{
${ }^{34}$ Jean Baker notes that while describing the evil effect of political parties, Americans often employed slavery as a metaphor to express the fears that parties had on republican virtue. Baker, Affairs of Party, 116. Several sermons about Harrison's death confirm Baker's assessment and use slavery as a metaphor for national sins and party strife.

${ }^{35}$ For information on the fears and reactions to deception and hypocrisy in northeastern cities in the antebellum era, see: Karen Halttunen, Confidence Men and Painted Women: A Study of Middle-Class Culture in America, 1830-1870 (New Haven: Yale University Press, 1982). There are many similarities between the anxieties over conmen and hypocrisy and the antiparty sentiment over demagogues and corruption in antebellum politics.

${ }^{36} \mathrm{~J}$. Abbott references the increased sin in cities during his sermon on Harrison. "The growing profanity and indifference to restraint on the part of the young - the pollutions and vices of our great cities - and the shocking scenes of assassination and cold blooded murder," stated Abbott about the types of national sins that the cities generated. See J. Abbott, A Sermon Preached on the National Fast, May 14, 1841:

Occasioned by the Death of William Henry Harrison (Salem: WM. Ives \& Co., 1841), 17.
} 
republican traits of the Founding generation. ${ }^{37}$

Harrison's military record, religious references in public addresses, skepticism of political parties, and perceived disinterestedness in public gain, made him well suited to be an antidote to demagoguery. Eulogists emphasized that record and its similarities to the Founding Fathers. "Like that of Washington, his whole character is unintelligible, except on the supposition of a deep and home-felt piety," argued Wheeler. Public men such as Washington and Harrison did not have their interests devoted to a party, but rather "they sought to advance the public interests in such a way as truth and justice demanded, and thus to carry society on towards its perfection. ${ }^{38}$ In order for the millennium to arrive, the country's politicians needed to rise above party loyalties. Ichabod Spencer thought Harrison's reforms and his inaugural address seemed to be "bringing us back to the sentiments of the times in which he was cradled." ${ }^{39}$ Making connections to the Founding generation both soothed anxieties about the current condition of American culture and gave patriotic reasoning to argue for a change in the values of public leaders.

Connections made to past political leaders provided an opportunity to speak out against the moral downfall of certain politicians and the democratic political culture in which they thrived. Harrison's antidemocratic and respectable qualities contrasted with those of Andrew Jackson, the principal figurehead of the Democratic Party. In speaking about Harrison, John Wheeler noted, "there are no violations of moral obligation, no stains upon his moral character, no duels, no gusts of passionate feeling, no acts of

\footnotetext{
${ }^{37}$ John Wheeler, A Discourse Occasioned by the Death of Gen. William Henry Harrison, President of the United States, Delivered Before the Citizens of Burlington and Vicinity, April 23, 1841 (Windsor: Chronicle Press, 1841), 15-16, 26-27.

${ }^{38}$ Ibid., 27.

${ }^{39}$ Spencer, The National Warning: A Sermon, 21.
} 
sudden oppression." Wheeler's comments are as much a condemnation for the actions of Andrew Jackson and Whig leader, Henry Clay, as they are admiration for Harrison's character. Both Jackson and Clay embodied political partisanship and the moral qualities that fostered evangelicals' dismay about antebellum culture, since they shared commonalities such as southern slaveholding plantation owners who had a history of dueling and other unsavory moral behaviors that put them at odds with the northern evangelical base. ${ }^{40}$

The delicate nature of American politics hinged on whether republican citizens were aware of the dangers of corruption and demagoguery. The Bowdoin educated lawyer John H. Sheppard maintained that his eulogy was apolitical, thus excusing it from "party feelings" that might "excite conflicting emotions." At the request of a committee of Wiscasset citizens, Sheppard delivered a eulogy for Harrison on a state day of fast. He connected Harrison's character to George Washington and alluded to the deaths of Jefferson and Adams in 1826 when proclaiming the role of Providence in Harrison's death. His eulogy provided him a platform to speak out against the possibility of war with England over border disputes. He voiced concern that men of "fiery passions and rampant ambition" sought to plunge the nation into war. The current crisis of which Sheppard spoke fit more broadly into the problem of a degraded democratic political culture. $\mathrm{He}$ reminded his listeners that their republic was "exposed to intestine danger, inferior only to war and too often fatal to a Democratic government." Undeserving men in political positions threatened the republic's safety by risking war. He urged the study of former republics to understand the vices and dangers that loomed. Most significant was the risk of the "intrigues of artful demagogues and designing men of every party, and from the

\footnotetext{
${ }^{40}$ Wheeler, A Discourse Occasioned by the Death of Gen. William Henry Harrison, 25.
} 
violence of party spirit itself." The solution, according to Sheppard, was the work of intelligent and virtuous communities, which he asserted was the only true foundation of a republic. "We all have duties to perform," he reminded his listeners as he appealed to republican duty to fight off the corruption of the nation's democratic culture. ${ }^{41}$

Antislavery eulogists also used the nation's period of mourning to speak out against the institution of slavery and the need to cleanse the country of such a sin.

Antislavery evangelicals viewed the country's tolerance of slavery as a leading reason for God taking Harrison away from the nation, and saw themselves as active agents to spread Christianity and help free the country of national sins. "That our government has been and is guilty of wrong done to the red man, and the black man, must be admitted by all," lamented pastor Charles Porter, who, like many evangelicals, linked the country's sinful treatment of African Americans and Native Americans. Porter was no abolitionist, but he maintained that slavery's existence in the republic had "long been crying to heaven for vengeance." With Harrison's death, Porter asserted the wrongs of the country against minorities had finally forced God's hand in judgment and retribution. He believed it served as a reminder that God was mindful of the nation's sins. ${ }^{42}$

New England Presbyterian pastor William Sprague urged his congregation to take a more active role in speaking out, not just against slavery, but also against the tolerance

\footnotetext{
${ }^{41}$ John H. Sheppard, An Eulogy Pronounced at Wiscasset, in the Afternoon of the State Fast, April 22d, 1841 on William Henry Harrison, Late President of the U.S. Delivered and Published at the Request of a Committee of the Citizens of Wiscasset (Wiscasset: R.B. Caldwell, 1841), 5-6, 16, 20. For similar sentiments on Harrison's nonpartisanship, see: Hugh S. Carpenter, Eulogy on the Late William Henry Harrison, President of the United States; Delivered Before the Eucleian Society of the University of the City of New-York, May 28, 1841 (New York: Hopkins \& Jennings, 1841), 16.

${ }^{42}$ Charles S. Porter, A Discourse Occasioned by the Death of Wm. Henry Harrison, Delivered April $18^{\text {th }}$, Repeated by Request, April 25 $5^{\text {th }}, 1841$ (New York: Chatterton \& Crist, 1841), 17. For information on his views of slavery, see: Carwardine, Evangelicals and Politics in Antebellum America, 141. For similar sentiments regarding slavery, see: Abbott, A Sermon Preached on the National Fast, 16. Of course, not all antislavery ministers resided in the northeast. For an example of an antislavery sermon after Harrison's death from a border region, see: Joshua L. Wilson, A Sermon, In Memory of the Death of William Henry Harrison, the Late President of the United States (Cincinnati: The Republican Office, 1841), 11-13.
} 
of moderates who did not do enough to stop the institution. To the Yale and Princeton educated Sprague, the enforced "silence" of the notorious "gag rule" was equally as sinful as the institution of slavery and a leading reason for its perpetuation. The country could no longer remain inactive for their consciences and of God's will. Many in the country believed that the supposed instances of divine intervention that illuminated the early republic's history confirmed American exceptionalism, but Sprague believed that much of the exceptionalist rhetoric hid the nation's sins. From the time of the country's founding to Harrison's death, the nation's priorities had gone off course. In Sprague's opinion, citizens could no longer tout its exceptionalism while tolerating such an institution as slavery. ${ }^{43}$ Harrison's death brought abolitionist sensibilities to the surface of American politics and heightened fears about God's wrath if the institution remained intact. Benjamin Labaree sought an immediate solution to end the institution. "The perpetuity of our government demands it, the temporal and eternal interests of the ignorant, degraded slave demand it, and, shall I not add, the equity of God's law demands it," he exhorted. ${ }^{44}$ Indifference over slavery was no longer tolerable, according to Labaree. He believed that to foreigners, to Americans, and to God, all who witnessed the curse of slavery throughout the land knew it was evil. Harrison's death provided the occasion to promote antislavery opinions.

Antislavery Reverend William H. Furness announced that national sins would provoke the vengeance of God when he spoke in front of his Philadelphia congregation after Harrison's death. Furness had increasingly used the pulpit in his Unitarian Church to

\footnotetext{
${ }^{43}$ Sprague questioned, "But that with all our eulogies of freedom, and all our pretended abhorrence of slavery, we are, after all, willing that this sin should lie at our door?" as he urged citizens to become more active in democracy in order to fight against democratic culture. Sprague, Voice of the Rod, 25.

${ }^{44}$ Labaree, A Sermon, 20-21.
} 
speak out against the wrongs of slavery, which drew the ire of some of his congregants. ${ }^{45}$ In his estimation, it was now up to Christian Americans to answer God's call of repentance and end such sins. If not, it would be an "insult to the memory of the dead-it is an abomination in the sight of Heaven. ${ }^{, 46}$ Much of this sermon was devoted to speaking out against slavery and the North's penchant for confessing the evils of slavery but then falling victim to the South's paternalistic claims about the institution and the reasons for its continuation. In Furness's opinion, the toleration of slavery spoke poorly of the evangelicals' spirit. "But you will say, why agitate this subject here?” he asked. "Here in this part of the country are no slaves. I know it, and thank God. Still the influence of slavery is here. It has quenched the generous glow of freedom at the North. It has weakened and blinded our sense of justice.” Many evangelicals no longer viewed slavery as merely a sectional issue. It was a national concern, and God had sent a clear message with Harrison's death that condemned northern inaction on the subject. However, northerners were far from united on their opinions of slavery. As indicated by Furness's congregation, which voiced some disapproval with his antislavery sermons, citizens divided on the morality of slavery and the role of religion in discussing the institution. $^{47}$

By the 1840s, some northerners became increasingly fearful that northern inaction in the democratic system enabled a Slave Power in the South to take control of the federal government. Despite having abolished slavery in the North, northerners were complicit in the institution as well, in Furness's estimation. "Do not these things show, that although

\footnotetext{
${ }^{45}$ Elizabeth M. Geffen, "William Henry Furness: Philadelphia Antislavery Preacher," The Pennsylvania Magazine of History 82, (1958): 273.

${ }^{46}$ W.H. Furness, A Sermon Delivered May 14, 1841, on the Occasion of The National Fast Recommended by the President (Philadelphia: John C. Clark, 1841), 3.

${ }^{47}$ Ibid., 9.
} 
there are no slaves here, the spirit and power and influence of slavery prevails?" His answer was an emphatic yes, and Christians could no longer "remain silent and indifferent and be guiltless." For many northern evangelicals and abolitionists, that way was through the rejection of the two-party system that tolerated the institution, and through a political coalition that would agitate for the abolition of slavery. Paradoxically, for many of the abolitionists, they found their answer to the two-party system in the Liberty Party, which formed in 1840 to advocate for abolition. Over the next few years, the Liberty Party would witness its greatest influence.

Of course, not all eulogists for Harrison used his death to speak out against slavery. Ichabod Spencer, for example, did not discuss slavery during his sermon. Spencer disagreed with abolitionists and criticized them throughout his public career for endangering law and order. He condemned abolitionism as he did party strife. ${ }^{48}$ Southern eulogists not surprisingly disagreed that God's action by taking Harrison was in response to the wrongs of slavery, yet they agreed that it was a message about the excessive party strife throughout the nation. Methodist Reverend David Doggitt denounced the current state of democracy while speaking to students at Randolph Macon College. "This event triumphantly rebukes the folly of feverish and convulsive elections," he asserted in his sermon. He continued to stress the importance of obedience to the law and the government unless it violated the constitution of a state. ${ }^{49}$ Former Andrew Jackson cabinet member and Jacksonian Democrat John M. Berrien echoed Doggitt's view of

\footnotetext{
${ }^{48}$ Spencer, The National Warning, 17-18; Elizabeth Fox-Genovese, The Mind of the Master Class: History and Faith in the Southern Slaveholders' Worldview (New York: Cambridge University Press, 2005), 629.

${ }^{49}$ David S. Doggitt, A Sermon on the Occasion of the Death of General William Henry Harrison, Late President of the United States, Delivered in the Chapel of Randolph Macon College, April 18, 1841 (Richmond: The Christian Advocate, 1841), 22, 18. For similar antiparty sentiments from a southern eulogy, see: Benjamin Parsons, Eulogy on the Private and Public Character, and Public Services of the Late President Harrison (Pensacola, 1841), 10.
} 
obedience to the law, yet continued to specifically defend slavery in his eulogy of Harrison. He noted Harrison's unique experience as a man from a slaveholding state but who was a Representative from a state "where fanaticism was striving to exert its maddening sway," yet he defended the rights guaranteed in the constitution, Berrien contended. He used his eulogy to deliver a constitutional defense of slavery and to uphold the notion that the constitution was a compact of sovereign states. Like other eulogists, he viewed Harrison's death through an antiparty lens in order to exert his view of politics. He lauded those who threw off the "habiliments of party" and who purified "their hearts from its bitterness" in order to pay homage to Harrison. Although Berrien served in Jackson's administration, he was elected as a Whig to Congress in 1841 and eventually joined other extremist southern Democrats in the Southern Rights Party. ${ }^{50}$

Antipartyism proved unable to keep citizens within the Whig coalition when some northern Whigs viewed southerners as a "Slave Power" faction. Antislavery sentiment throughout the North and within their party forced Whig politicians to appeal to antislavery constituencies, promote "Northern rights," and identify the party more closely with antislavery goals. ${ }^{51}$ In order to stay viable nationally and keep southern Whigs within the party, Whig politicos had to tout their credentials as the surest guardians of the peculiar institution. ${ }^{52}$ Thus, the need for the Whigs to reconcile its northern and southern

\footnotetext{
${ }^{50}$ John MacPherson Berrien, Eulogy on the Life and Character of William Henry Harrison, Late President of the United States: Delivered Before the Citizens of Savannah, in the Independent Presbyterian Church, on Wednesday, May $12^{\text {th }}, 1841$ (Savannah: W.T. Williams, 1841), 15, 22. For information on Berrien, see: William W. Freehling, The Road to Disunion: Secessionists at Bay 17761854 (New York: Oxford University Press, 1990), 271, 436, 444-446.

${ }^{51}$ James Brewer Stewart, "Abolitionists, Insurgents, and Third Parties: Sectionalism and Partisan Politics in Northern Whiggery, 1836-1844," Crusaders and Compromisers: Essays on the Relationship of the Antislavery Struggle to the Antebellum Party System, ed. Alan M. Kraut (Westport: Greenwood Press, 1983): 30.

${ }^{52}$ William Cooper, The South and the Politics of Slavery 1828-1856 (Baton Rouge: Louisiana State University Press, 1978). In his study of politics in the South, Cooper argues that the intensity of 1840's
} 
members over slavery led to increased antiparty sentiment throughout the North, and a perception by both sections that the other subverted republicanism for political gain. Antislavery Whigs defected from the party and began joining the Liberty Party. The antiparty spirit and disapproval of the Whigs and Democrats ultimately led these factions to seek solutions to their concerns about democratic culture through democratic means, confirming historian James Brewer Stewart's characterization of the Liberty Party's actions as "political antipolitics.",53

The rise of the Liberty Party coincided with the largest test of slaveholders' control of politics since the Missouri Compromise in 1820, as volatile debates regarding possible Texas annexation raged from the floors of Congress to family parlors across the country. Texas annexation, many feared, would open new western land for the expansion of slavery and its power in politics. While Whigs, who largely opposed annexation, proved effective in holding together the differing factions within its party, they still lost members between Harrison's death and the presidential election in 1844, and the Liberty Party grew tenfold during those years. ${ }^{54}$ The fate of Texas, slavery, and the two-party system depended much on the outcome of the presidential election of $1844 .^{55}$

John Tyler's ascension to the presidency after Harrison's death put an end to the hopes of many Whig politicians for implementing Whig policies. Tyler proved to have

conflicts grew out of exploitation of the politics of slavery, as each party presented itself as the surer guardian of slavery, and not out of party differences in financial matters, even though these issues dominated state politics in the years beforehand.

${ }^{53}$ James Brewer Stewart, Holy Warriors: The Abolitionists and American Slavery (New York: Hill and Wang, 1976), 97; Alan M. Kraut, "Partisanship and Principles: The Liberty Party in Antebellum Political Culture," In Crusaders and Compromisers, 72.

${ }^{54}$ Stewart, "Abolitionists, Insurgents, and Third Parties: Sectionalism and Partisan Politics in Northern Whiggery, 1836-1844," in Crusaders and Compromisers, 35.

${ }^{55}$ For contrasting views over the nature of the Liberty Party, see: Richard Sewell, Ballots for Freedom: Antislavery Politics in the United States 1837-1860 (New York: Oxford University Press, 1976) and Ronald G. Walters, The Antislavery Appeal, American Abolitionism After 1830 (Baltimore: Johns Hopkins University Press, 1976). 
little in common with other leading Whigs. The Election of 1844 provided a new opportunity for the Whigs to control the Executive Branch, and the party nominated Henry Clay. The Democrats nominated James K. Polk, an expansionist and slaveholder from Tennessee, while the Liberty Party decided on James G. Birney. Despite agreement on Texas, evangelicals and abolitionists still saw Henry Clay as someone who did not uphold Christian attributes worthy of their support. Not until Clay's death in 1852 did evangelicals hail Clay's acceptance of Christianity toward the end of his life. Cognizant that Clay's habits did not align with northern evangelicals', Democrats seized the opportunity to highlight his moral liabilities and drive abolitionist Whigs into the arms of the Liberty Party. As Richard Carwardine shows, the Democrats portrayed Clay as a hypocritical slaveowner and asked whether "any Christian parent wishes his sons to follow Mr. Clay's example in gambling, duelling, and slave holding. ${ }^{, 56}$ Strategically, the Democrats did not have to convince voters of the merits of Polk, they just had to convince evangelicals that Clay was not a suitable choice and that they needed to look to a third party for their solution.

Liberty supporters were uncompromising on their platform and viewed the compromise and conciliation of the Whigs and Democrats as a leading reason for the perpetuation of national sins. While some northern evangelicals and abolitionists publicly claimed they disowned politics due to its corruption, others saw it as their duty as virtuous republican citizens to reform American politics and make it more respectable. Although Liberty men did not believe in the patronage of the other political parties, the Liberty Party did take on many of the same organizational structures and tactics of the

\footnotetext{
${ }^{56}$ Carwardine, Evangelicals and Politics in Antebellum America, 80.
} 
other parties. ${ }^{57}$ Antiparty Liberty supporters used the means of democratic culture in order to fight against it. Liberty songs, slogans, rallies, and celebrations reflected the party fighting democracy by employing some of the tactics of the democratic political culture used by the Democrats and Whigs, even as they also sought moral reform of the political and social order. ${ }^{58}$ The links between evangelical and abolitionist political involvement were evident in popular culture as well. The Hutchinson family, a wellknown abolitionist musical group, infused politics into their moral crusade against slavery. The sheet music for their song "Get Off the Track!" displays an allegorical picture of the triumph of abolitionism. The illustrated sheet music portrays two railroad cars, one named "Immediate Emancipation" and the other, "Liberty votes and Ballot Boxes" in front of a welcoming crowd. Beyond the cars is a church on the hillside with two locomotive trains with one marked "Van" and the other "Clay" crashing and causing their passengers to flee (figure 5). These cars, portraying the Democratic and Whig leaders, represent the strong connection between religion and antislavery politics in the early 1840 s, as Liberty supporters used antiparty rhetoric to fight for the return of republican virtue and against the sinful nature of the Whigs and Democrats. ${ }^{59}$

The three political parties understood the importance of using satire to reach a mass audience and employed political cartoons to sway opinion over Texas and religion for their own benefit. "Going to Texas after the election of 1844 " was a pro-Whig cartoon that predicted Whig victory in the election and showed Polk and Andrew Jackson dejectedly packing a donkey for a trip to Texas while Henry Clay watches from the

\footnotetext{
${ }^{57}$ Kraut, "Partisanship and Principles: The Liberty Party in Antebellum Political Culture," in Crusaders and Compromisers, 89.

${ }^{58}$ Ibid., 81.

59 "Get off the track! A song for emancipation, sung by the Hutchinsons,..." (Boston: Thayer \& Co's., 1841).
} 
White House (figure 4). ${ }^{60}$ Democratic cartoons, however, used Whigs and their positions to portray them as tyrants and the Democrats as defenders of liberty. Cartoons attempted to belittle Whig Vice Presidential candidate Theodore Frelinghuysen, whom Whigs touted as upholding the evangelical values that Clay lacked. They portrayed Clay as a fraud. Cartoons charged Frelinghuysen, along with Clay and Daniel Webster, with being demagogues who were merely agents for wealthy and religious interests (figure 2) ${ }^{61}$

James K. Polk won a close election, again placing the Democrats in the Executive office and the party in control over the issue of Texas. Whigs blamed the Liberty Party for costing them the Electoral College win by small margins of the popular vote in New York and Michigan. Historians still debate the influence that the Texas annexation had on Whigs defecting to the Liberty Party for the election. As Michael Holt contends, "Texas was a party, not a sectional issue in this election," yet historians have looked to Clay's waffling on the issue leading up to Election Day as a reason for his defeat. ${ }^{62}$ Other historians emphasize tariff and financial issues to show that Liberty Party supporters who hailed from Whig ranks arrived to the Liberty Party indirectly and not necessarily because of Clay's handling of Texas. While it only received 3.3\% of the national vote, the Liberty Party undoubtedly played an important role, not only on the 1844 election, but on the ideological positions of the Whig Party as well. ${ }^{63}$ The Liberty Party's influence

\footnotetext{
60 "Going to Texas after the election of 1844," (New York: James Baillie, 1844).

61 "The masked battery of Loco-Foco Strategy," (New York: James Baillie, 1844); “Tyrants prostrate liberty Triumphant," (New York: James Baillie, 1844).

${ }^{62}$ Stewart, "Abolitionists, Insurgents, and Third Parties: Sectionalism and Partisan Politics in Northern Whiggery, 1836-1844," in Crusaders and Compromisers, 35. Historians Ronald Formisano, Daniel Walker Howe, Richard P. McCormick, Robert Remini, and John Niven are some of the most well known supporters of this argument. For an example of a study that does not believe the 1844 election was not exclusively a referendum on Texas Annexation, see: Lee Benson, The Concept of Jacksonian Democracy: New York as a Test Case (Princeton: Princeton University Press, 1961).

${ }^{63}$ Lex Renda, "Retrospective Voting and the Presidential Election of 1844: The Texas Issue Revisited." Presidential Studies Quarterly 24, (1994): 837-838.
} 
in the early 1840 s is a testament to the antiparty nature of politics. Rather than a demonstration of support for the main political parties, the high voter turnout and amount of citizens actively engaged in public politics displayed the concerns that citizens had about the practice of democracy in political culture. Citizens sought ways of fighting against factions and demagoguery and lessening the hold of parties on politics by entering into the political arena to change it from within.

The Liberty Party helped sectionalize the issue of slavery during the Texas debates, forcing northern Whigs to take stronger anti-southern postures, and leading them increasingly to support "Northern rights" in opposition to the Slave Power and “doughfaces" who were soft on slavery. The Whig Party held together as a national force by reconciling southern slaveholders who largely voted Whig for economic issues with the increasingly antislavery northern Whigs who had to harden their positions against slavery in order to prevent its constituents from defecting to the Liberty Party. ${ }^{64}$ Yet, while Whigs were able to stay united over Texas annexation, the westward expansion of slavery made the Whig coalition untenable. The "political antipolitics" of the Liberty Party never gave them a realistic chance at winning power, but it did offer them the opportunity to play the role of spoiler in elections and raise questions about the virtue of the party system. As a result, the Liberty Party helped corrode the two-party system by encouraging more antiparty sentiment, pushing northern Whigs into stronger antislavery positions, and shifting the issue of slavery "from the pulpit to the stump.",65

Shortly after the Democratic triumph in the Election of 1844 and the perceived

\footnotetext{
${ }^{64}$ Stewart, "Abolitionists, Insurgents, and Third Parties: Sectionalism and Partisan Politics in Northern Whiggery, 1836-1844," in Crusaders and Compromisers, 35.

${ }^{65}$ Kraut, "Partisanship and Principles: The Liberty Party in Antebellum Political Culture," in Crusaders and Compromisers, 89-92.
} 
national endorsement of Texas annexation and Manifest Destiny, Democrats came together to mourn the loss of their party's retired leader, Andrew Jackson. Just months after Polk took office, Jackson passed away at his home in Tennessee. Although Jackson had retired from public office, his influence on the Democratic Party and conceptions of America's political culture lingered. Upon his death, ministers and Democratic supporters gave eulogies that shaped his memory to promote a Democratic vision of American republicanism and exceptionalism in order to soothe fears of expansionism. Democrats employed Jackson's legacy to promote cohesion in an increasingly oppositional style of American democracy in the mid-1840s. ${ }^{66}$ Supporters of Jackson and Democratic Party platforms reinforced “American” traits through panegyrics highlighting Jackson's altruism and reinforced the belief that Providence guided America by connecting Jackson to the supposed divine blessings bestowed upon the Founding generation. ${ }^{67}$

Those who paid tribute to Jackson attempted to transform perceptions of him from a highly partisan politician to a man who governed above partisanship in ways similar to George Washington. Orators resurrected the traits of Jackson that helped sweep him into the presidency. Campaign biographers during Jackson's bid for the presidency portrayed him as a political outsider, disconnected from political factions, and a military man who had sacrificed for the common good. ${ }^{68}$ After his death, eulogists again highlighted these traits to tap into antiparty and republican sentiment to show that the Democratic Party

\footnotetext{
${ }^{66}$ Historians increasingly view the growth of American democracy as a period of opposition and conflict. For a more in-depth analysis on this issue, see: Mary Ryan, Civic Wars: Democracy and Public Life in the American City during the Nineteenth Century (Berkeley, University of California Press, 1997).

${ }^{67}$ Andrew Burstein, "Immortalizing the Founding Fathers: The Excess of Public Eulogy" in Mortal Remains: Death in Early America, in Andrew Burstein and Nancy Isenberg, eds., (Philadelphia: University of Pennsylvania Press, 2003): 104. Burstein makes the argument that eulogists of national leaders selfconsciously produced a catalogue of "American" traits.

${ }^{68}$ Kruman, "The Second American Party system and the Transformation of Revolutionary Republicanism," $520-521$.
} 
was the party of "the people" and its leaders were the successors to the Founding generation.

In a similar fashion to sermons about Harrison, eulogies often compared Jackson to Washington militarily, personally, and politically. General Benjamin C. Howard, who served in Congress during part of Jackson's presidency, hoped God would someday give the country another warrior-statesman like Washington or Jackson. "The swords of these two men were drawn to oppose the same enemy, and may God, in his protecting Providence, grant that ... there may be found a third worthy to be associated with Washington and Jackson," he explained while making a direct comparison between the sacrifices both men gave for the sake of the country. ${ }^{69}$ Reverend Thomas Brainerd, who had Whig sympathies, asserted in his sermon that he believed "no president since the days of Washington ever carried to the presidential chair a more patriotic and honest heart." Gone were the days of bitter partisanship, he argued. Whether Brainerd truly felt this way about Jackson despite not being aligned with his politics is up for interpretation. However, Brainerd asserted that one of the objectives of his sermon was to promote national happiness, and one of the ways to do so was through " $a$ spirit of peace and order." He lamented the painfulness of party strife and his sermon provided a platform to obscure partisan feelings after the contentious 1844 election, even through the memory of a leading partisan in American politics. ${ }^{70}$

Jackson's supporters believed he saved the country from illegitimate factions and secured the continuation of democracy. Jackson's rhetorical worth to the Democrats now

\footnotetext{
69 "Eulogy Delivered at Baltimore, July 1, 1845, by Gen. Benj. C. Howard," in Monument to the Memory of General Andrew Jackson, 89.

70 "A Sermon, by the Rev. Thomas Brainerd, Preached to his Congregation in Pine Street Church, July 6, 1845." In Monument to the Memory of General Andrew Jackson, 365, 360; Carwardine, Evangelicals and Politics in Antebellum America, 122.
} 
rested in the republican virtue that Democrats asserted he possessed. Proponents saw Jackson as an ideal republican leader, cut from the same cloth as the Founding Fathers, even though he perfected the spoils system during his tenure as president and was portrayed as "King Andrew" by his opponents because they believed he misused executive power. Georgia Democratic politician and lawyer Herschel Johnson believed that republicanism still pervaded the American mind. He explained that America's republicanism was one of social and political equality, and that it protected the weak against the strong and shielded the laboring classes from associated wealth and privileged monopolies. "This is the Republicanism of America," he declared. "General Jackson was the embodiment, the personification, aye, the incarnation of this all pervading sentiment which fills the minds of the freemen of this land," he continued. Johnson believed that was what "enthralled him in the hearts of his countrymen." While some of the basic tenets of republicanism remained consistent throughout early American history, there was no single republican ideology. Visions of American republicanism took on many definitions, depending on the period and the individual. ${ }^{71}$ Johnson's description of republicanism displayed an egalitarian twist. American democracy developed during Jackson's two terms of office, and Johnson's understanding of the republican form of government incorporated that democratic influence and gave credit to Jackson for protecting the political ideals of "the people." 72

Eulogists highlighted attributes supposedly held by the Founding generation to strengthen "American" traits and connect Jackson to the founders and such attributes.

\footnotetext{
${ }^{71}$ Herschel V. Johnson, Oration on the Life and Character of Andrew Jackson, Delivered at the Request of the Citizens of Baldwin Co., in the Representative Chamber, at Milledgeville, GA., on the $16^{\text {th }}$ Day of July, 1845 (Milledgeville, 1845), 14.

${ }^{72}$ For more on views of republicanism, see: Steven J. Ross, “The Transformation of Republican Ideology," Journal of the Early Republic 10, (1990): 324.
} 
Levi Woodbury exhibited those sentiments during his eulogy delivered in front of an audience in New Hampshire. "His whole life [was] devoted to defend the liberties of his country, rather than like others to break them down," he asserted. He continued to note that Jackson, "like the humblest citizen, retiring to his farm, instead of striving, like many, to usurp authority, or prolong the pomp and pageantry of office." Woodbury did not just praise Jackson's republican virtue, but also did so by contrasting that virtue to the growing mistrust of others not sharing those traits in public office. ${ }^{73}$ Just as evangelicals viewed Harrison as being above Whig political electioneering in 1840, now Democrats sought to place Jackson in a similar light as someone who was above party strife. Thus, the attempt to portray Jackson in such a way confirms the acknowledgement of strong antiparty sentiment and the desire by Democrats to depict themselves as defenders of liberty.

Even for eulogists who did not align politically with Jackson, the public platform of delivering a eulogy displayed the contested memories of Jackson and enabled the opportunity to exert political desires. In referencing the domestic dangers that threatened the future of the country, prominent Boston attorney and Anti-Mason Pliny Merrick argued, "The great object which Andrew Jackson proposed to himself in his civil administration was to maintain and strengthen the republican institutions of his country," which reinforced anti-Masonic desires to uphold republicanism over the perceived corruption of government by Masons. Merrick spent much of his eulogy touting Jackson's military record, defense of republicanism, and commitment to upholding the

\footnotetext{
73 "Eulogy Delivered at Portsmouth, New Hampshire, July 2, 1845, by the Hon. Levi Woodbury," in Monument to the Memory of General Andrew Jackson, 85. For another example, see: Monument to the Memory of General Andrew Jackson, 145. Pennsylvania Democratic Governor Francis Shunk used "American" traits to connect Jackson to the founders. "Washington, Franklin, Adams, and Jefferson, and many others, are names distinguished for virtue, disinterestedness, and patriotism," he argued.
} 
law. "The supremacy of the law was therefore, with him, an inborn, ingrained, indwelling people," Merrick told his listeners. In particular, Jackson's defense of the law during the Nullification crisis provided a common link between him and Jackson. "It is of his glory to have practically exemplified the exhortations of Washington by an actual salvation of the Union," he claimed, continuing, "The hopes for its perpetual duration were never brighter than when his eye cast its last glance on the prosperity of the country." To Merrick, Jackson's ability to preserve the country after the Nullification crisis and other sectional tensions was akin to the legacy of Washington, and he did not let partisanship stop him from doing what was best for the country. ${ }^{74}$

General Howard, a Democrat, thought that even in death Andrew Jackson worked to unite the country. "Here are men of all political parties, gathering under the flag of the stars and stripes, to lay aside for a short time all differences of opinion, and in the name of their common country ... to pay a token of respect to the memory of the patriot and soldier," he claimed. Through memorialization, Democrats could mold Jackson's image and actively assert that paying tribute to Jackson was also paying tribute to the nation. Connecting Jackson with the Founders and to patriotism allowed Democrats to craft this understanding of American exceptionalism as a political tool to combat Whig claims that the Democrats were guilty of degrading America's republic through political ploys and partisanship. With Jackson dying soon after Democratic victory in the Election of 1844, Democratic eulogists used their orations to obscure the party's electoral partisanship

\footnotetext{
74 "Eulogy Delivered at Boston, Mass., July 9, 1845, by the Hon. Pliny Merrick," in Monument to the Memory of General Andrew Jackson, 176, 177, 181. For more on Anti-Masonry, see: Michael F. Holt, "The Antimasonic and Know Nothing Parties," in Arthur M. Schlesinger Jr., History of U.S. Political Parties, (New York: Chelsea House Publishers, 1973), I, 575-620.
} 
during the election. ${ }^{75}$

Jackson's death sparked an outburst of religious sentiment from Democrats who sought to ease evangelical concerns about their party. The Whigs had generally controlled much of the evangelical support, and Jackson's passing served as a way for Democrats to tout their party's credentials as the party best suited to defend Christianity. One way to do so was to show that Jackson, like Washington, was an instrument of God who saved and protected the country. "Jackson was early made conscious that he was an instrument, in the hands of God, for some great and wise purpose," asserted Virginia attorney Hugh Garland, who believed that Jackson was a "martyr spirit" whose "deep enthusiasm and benevolence of his heart, inspired him with a noble zeal for the good of his country and mankind." ${ }^{, 76}$ Eulogists, particularly those who were not members of the clergy, spoke of Jackson and the Founders as if they were "ordained" by God, just as church leaders were. Both appeared to receive mandates to be instruments of God, and both were part of God's Providential plan for America. Ministers warned against such idolatry in their sermons following Harrison's death, despite their hope that he would redeem politics. Although they might thank God for men such as Jackson or Harrison, they mostly preached that such worship of men was dangerous for the country and its salvation. Additionally, while evangelical eulogists for Harrison gave jeremiads touting reform, Jackson's advocates, who largely were Democrats, made general claims about Providence and sought to sustain Democratic dominance.

In an era of deception and fraud, Jackson supposedly upheld republican traits as

\footnotetext{
75 "Eulogy Delivered at Baltimore, July 1, 1845, by Gen. Benj. C. Howard," in Monument to the Memory of General Andrew Jackson, 87-88.

76 "Eulogy Delivered at Petersburg, Va., July 12, 1845, by Hugh A. Garland, Esq.," in Monument to the Memory of General Andrew Jackson, 207-208.
} 
an honest and Christian man who never put personal ambition above the interests of the country. To Herschel Johnson, God had blessed the country by creating someone with the character of Jackson, telling his listeners, "Whilst we commemorate the virtues of the departed patriot, let our hearts swell with emotions of sincere gratitude to the Giver of all good." ${ }^{, 77}$ With evangelical fears of political parties still elevated at the time of Jackson's death, Reverend D.D. Lore thought it imperative to show that Jackson was a Christian and that he died a Christian death. Doing so was important for both enhancing Jackson's legacy and showing evangelicals that the Democratic Party was a Christian coalition. Lore made certain to show that Jackson fulfilled all of the concepts of a "Good Death." In mid-nineteenth century, dying was an art, and the Good Death had long been at the core of Christian practice. ${ }^{78}$ Following the form of a Good Death, Jackson gave instructions to his family when he knew his death was near. He told his family to continue instructing the poor at the Sabbath School. According to Lore, Jackson believed it was important to blend the duties of religion with those of humanity. To show that Jackson always considered the Bible while making political decisions, Lore claimed that "[h]ere was a full-souled and intelligent Christian. He made the Bible the rule of faith and practice. He made the Bible the foundation of the liberties of his country." ${ }^{, 79}$ Connecting Jackson's politics with his religious faith sought to calm evangelical fears that the country's political sphere was becoming too secular. This correlation also helped in affirming that the Democratic Party was just as in-tune with evangelicals as the Whigs.

The emphasis on Jackson's Christianity in eulogies and sermons, particularly as

\footnotetext{
${ }^{77}$ Herschel V. Johnson, Oration on the Life and Character of Andrew Jackson, 14.

${ }^{78}$ Drew Gilpin Faust, This Republic of Suffering: Death and the American Civil War (New York: Alfred A. Knopf, 2008), 6-7.

79 "Eulogy Delivered at Pottsville, PA., July 10, 1845, by Rev. D.D. Lore," in Monument to the Memory of General Andrew Jackson, 340-342.
} 
he was on his deathbed, served a vital purpose beyond merely showing that the Democratic Party was friendly toward evangelicals. Eulogists Highlighted God's role in Jackson's life and how Jackson submitted to a Higher Power to affirm the Democratic Party's position on slavery. Slavery was always a contentious sectional issue, and sermons after Harrison's death illuminated the growing intensity of antislavery sentiments throughout the North. The election results in 1844 gave Democrats confidence in their expansionist and favorable policies toward slavery, and Jackson's death offered a chance to bring their positions on slavery and Christianity together to promote Democratic policies. Antiparty, republican, and exceptionalist rhetoric opened the way for partisan advocacy, displaying the tension at the heart of the political culture. Antidemocratic concerns played a critical role in the making of democracy. While some citizens resisted the democratic movement through democratic means, partisans used the rhetoric of democracy's dissenters to galvanize party support.

Throughout the South, a fusion between proslavery ideology and religion had already begun before Jackson's death. Slaveholders were fearful of the power of evangelicalism during the Second Great Awakening, in particular because of the apparent antislavery sentiment of the religious movement. In order to gain support, southern ministers had to provide a version of evangelicalism that proved the religion was safe for slavery. Southern congregations taught slaves the importance of being faithful servants that respected their stations in life. Thus, southern evangelicalism became a valuable tool for defending the institution. ${ }^{80}$ In the North, conversely, the evangelical movement altered northern politics. For northern evangelicals, politics gave them a platform to voice

${ }^{80}$ Stephanie McCurry. Masters of Small Worlds: Yeoman Households, Gender Relations, \& the Political Culture of the Antebellum South Carolina Low Country (New York: Oxford University Press, 1995), 142144. 
their concerns as Christianity's connection with politics widened beyond just the slavery issue.

Across the country, Americans read and heard about Jackson's deathbed scene in eulogies, sermons, and newspapers. Historian and Democrat George Bancroft discussed Jackson's deathbed scene to promote the party in the eulogy he delivered for the solemn occasion. After describing Jackson's interaction with his family, Bancroft depicted Jackson's last encounter with his "servants," a euphemism used for slaves. After referring to the slaves who gathered around the dying man, "some in his room, and some on the outside of the house, clinging to the windows, that they might gaze and hear," Bancroft detailed Jackson's last words. "My dear children, and friends, and servants, I trust to meet you all in Heaven - all, both white and black," said Jackson in his final message to his slaves. ${ }^{81}$ As Jean Baker reminds us, Bancroft used his profession as a historian to advocate for the Democratic Party. In his multi-volume history of the United States, Bancroft makes little explicit mention of political parties. "Unlike Washington, Jefferson, and Madison, Bancroft did not condemn parties so much as deny them a place in history," asserts Baker. Bancroft and other like-minded Democrats obscured the role of political parties during the era and yet sought to show that the Democrats were the defenders of the republic and not a political party. In describing Jackson's deathbed interaction with his slaves, Democrats also validated their party's stance on the slavery issue and more broadly declared their legitimacy as an organization in the antiparty political culture. ${ }^{82}$

\footnotetext{
81 "Eulogy Delivered at Washington City, June 27, 1845, by George Bancroft, Secretary of the Navy of the United States," in Monument to the Memory of General Andrew Jackson, 50.

${ }^{82}$ Jean H. Baker, Affairs of Party, 119-123. Baker's study of northern Democrats shows the strong sense of party spirit that they held, yet also their awareness of antiparty spirit. Aware of the negative connotation of
} 
As northerners intensified their fight against slavery, southerners strengthened their resolve to defend the institution. Eulogies and sermons delivered for Jackson are indicative of how politics was a part of the daily lives of Americans beyond election periods. Democratic Vice President George Dallas supported the party's stance on slavery in his eulogy of Jackson. In this way, the eulogies reinforced conceptions of paternalism and Christianity's sanctioning of the peculiar institution. ${ }^{83}$ Jackson's interaction with his slaves provided a vignette displaying the paternalistic nature of slavery and the affection that slaves had for their masters. "No master could be more certain of reciprocated fondness than he was, when, as expiring, he breathed the hope of hereafter meeting in the heaven to which he was hastening, the servants of his household, 'as well black as white,"” Dallas exclaimed ${ }^{84}$ Hugh Garland expressed similar sentiments regarding the relationship Jackson had with his slaves. He claimed that "Seeing his servants anxiously pressing about the doors and windows of his chamber,” Jackson urged their faith in religion so "they might insure their eternal salvation, and join him in Heaven." ${ }^{, 85}$ Now, defenders of slavery could portray Jackson's death as paternalistic justification for the perpetuation of the institution, and hoped religious American voters could be reassured of the values of Democratic leaders.

The re-modeling of Jackson's image through his deathbed scene by Democrats in

parties, Democrats referred to their party as the Democracy in order not to have to mention "party" (page 112).

${ }^{83}$ For more on the proslavery ideology, see: Drew Gilpin Faust, ed. The Ideology of Slavery: Proslavery Thought in the Antebellum South, 1830-1860 (Baton Rouge, Louisiana Sate University Press, 1981). Faust notes that proslavery thought from the 1830 s onward was "more systematic and self-conscious." According to Faust, the defense of slavery "invoked the most important sources of authority in their intellectual culture and associated slavery with the fundamental values of their civilization" (pages 4, 10).

84 "Eulogy Delivered at Washington City, June 27, 1845, by George Bancroft, Secretary of the Navy of the United States," in Monument to the Memory of General Andrew Jackson, 58.

85 "Eulogy Delivered at Petersburg, Va., July 12, 1845, by Hugh A. Garland, Esq.," in Monument to the Memory of General Andrew Jackson, 209. 
both the North and South demonstrated attempts to strengthen the party on the slavery issue by removing Jackson from the partisan battleground and highlighting his private life as a republican statesman. The reaction and description of Jackson's deathbed scene illuminated how Democrats were united on its meaning in regard to slavery. Ohio lawyer William Irvin added his own flare in his eulogy when recounting Jackson's deathbed scene. "His household were all assembled, and around him were gathered children and servants, who would have died for him, could they have thereby assuaged his pain," he declared. Reverend Lore's eulogy in Pottsville, Pennsylvania, made sure to emphasize Jackson's final comments to his servants. "My dear children, and friends, and servants, I trust to meet you all in Heaven, both white and black! Both white and black!!' Lore ended his eulogy by reaffirming his didactic purpose, stating, "Long may his memory live. Long may his virtues be cherished and practiced by American Citizens." 86 Jackson's deathbed scene revealed a paternalistic figure removed from the divisive partisanship that defined his political career.

Through eulogies and sermons, the story of Jackson speaking to his slaves on his deathbed received much attention. As with any quotation passed from person-to-person and newspaper-to-newspaper, what exactly Jackson said is still in question. The focus on his words to his slaves, however, exhibits how Democrats sought to strengthen the notion that the master-slave relationship was a paternalistic one. They also tried to obscure slavery's role in democratic debate. A re-printed first-hand account of Jackson's funeral, titled "General Jackson and His Slaves," in the New-Hampshire Patriot, discussed Jackson's relationship with his slaves. In regard to the funeral, the attendee wrote: "There

\footnotetext{
86 "Eulogy Delivered at Pottsville, PA., July 10, 1845, by Rev. D.D. Lore," in Monument to the Memory of General Andrew Jackson, 341-342.
} 
was one thing that struck me very forcibly; he has always been charged with being tyrannical; but if the evidence of his slaves is testimony to the contrary, I am a witness that there was sorrow, universal, among what I suppose must have been some seventy or eighty." The writer continues, "You would see them standing ... in silent grief, the tears rolling down their dark faces. ${ }^{97}$ Jackson's death again highlighted the centrality of the slavery issue in American culture. Democrats used Jackson's paternalist relationship with his slaves to indirectly fasten views of Christianity, republicanism, and paternalism into justification for support of the Democracy and expansionism. Focus on Jackson's private life and paternal nature deflected attention away from his role in democratic politics. Democrats redacted his connection to democratic political culture and highlighted the merits of a republican household and paternalism.

Both sides displayed keen awareness to the antiparty impulse that was still significant throughout a political culture that had lingering suspicions of democracy. The employment of nonpartisan and republican language demonstrates that eulogists believed such rhetoric still served a vital purpose, whether because they supposed they had a receptive audience, or because they desired to bestow their beliefs onto the public. The Democratic Party temporarily proved more efficient than the Whigs at exploiting concerns about party politics and attempted to delegitimize political opposition by connecting their organization to traditional conceptions of republicanism. ${ }^{88}$ Whigs never formed a patronage system like that of the Democrats to help create party cohesion and become the majority party. And while the Democrats demanded party loyalty, the Whigs never could create such devotion due to strong antiparty sentiments within their ranks.

\footnotetext{
87 “General Jackson and His Slaves," New-Hampshire Patriot, July 3, 1845.

${ }^{88}$ Wilson, "Republicanism and the Idea of Party in the Jacksonian Period," 420.
} 
The Whigs failed to turn antipartisan and exceptionalist rhetoric into political victories because they could not come together over the most pressing issue — slavery. As Democrats were in harmony during the early 1840 s over their position on the institution, especially during the Election of 1844, the Whigs were unable to promote a national position that would allow for both northern and southern supporters to rally behind the Whig banner while simultaneously not betraying their republican ideals. The sermons for Harrison reveal this division between the Whigs, and the party leaders struggled to promote a united vision due largely to the antiparty nature of the political culture in the 1840 s.

Northern ministers who were favorable toward the Whig Party generally did not use their sermons to denounce the Democrats. Whig and Methodist Chauncey Hobart told his mournful congregants that Jackson's death was proof that "the nation was really one at heart; that although party strife was now and then fierce and bitter, yet below this, there was a unity of sentiment which only needed a proper occasion to call it forth." ${ }^{\prime 89}$ Despite his conciliatory eulogy of Jackson, Thomas Brainerd still spoke out against slavery. While he did not criticize Jackson for his position on slavery, he did speak out against the institution, claiming, "May God open the way for their final and safe emancipation." It would be in poor taste to criticize a recently deceased person in their eulogy; however, it was still possible to instill beliefs into the eulogy while not tarnishing the legacy of dead. ${ }^{90}$ George Bethune delivered a sermon following Jackson's death that was much more benign than the one he delivered after Harrison's passing. "You, who listened to me with so much candour, when I paid, four years since, an [sic]humble

\footnotetext{
${ }^{89}$ Carwardine, Evangelicals and Politics in Antebellum America, 8, 125.

90 "A Sermon, by the Rev. Thomas Brainerd, Preached to his Congregation in Pine Street Church, July 6, 1845," in Monument to the Memory of General Andrew Jackson, 358.
} 
tribute to the merits of him who reached the height of authority to sink into the grave watered by a nation's tears," Bethune declared, that he would "not condemn my utterance of similar emotions now." ${ }^{" 91}$ His sermon lacked the national urgency to expunge the national sins of political strife. While the sins and dangers plaguing the nation were mentioned, Jackson's death, partly because he died in retirement rather than while in office, brought a conciliatory tone from his eulogists. Indeed, the reaction to Jackson's passing by his supporters is similar to that seen after the deaths of the Founding generation.

Some abolitionists did assail Jackson and his policies that went against their beliefs. The North American Daily Advertiser criticized eulogies and sermons of Jackson for promoting political falsehoods. "In common with tens of thousands of the most intelligent citizens of the republic, we deny to Jackson the virtues accorded to him by his panegyrists," argued the paper. Even though the publication held George Bethune in high regard, it disapproved of his sermon. "It is one thing to give partisan sympathy the license allowed in processions and eulogies ... [,] but upon any exhibition beyond that mark we claim the right to comment freely," stated the newspaper in response to his sermon for Jackson. ${ }^{92}$ The contested memories of Jackson are indicative of the tenuous relationships within the Whig coalition. In order to remain in the favor of many Americans, Whigs had to show a level of respect and acknowledgement for Jackson's patriotic attributes that Democrats extolled. Resentment within Whig ranks indicates that theirs was not a united response, and feelings of antipartyism and differing views about American

\footnotetext{
91 "A Discourse on the Duty of a Patriot, with some Allusions on the Life and Death of Andrew Jackson; Pronounced July 6, 1845, by George W. Bethune, Minister of the Third Reformed Dutch Church, Philadelphia," in Monument to the Memory of General Andrew Jackson, 353.

92 "A Discourse on the Duty of a Patriot," The North American and Daily Advertiser, July 23, 1845.
} 
exceptionalism left the Whigs more vulnerable to its supporters leaving the party.

The Democratic Party temporarily had success in exploiting their position as the majority party to further their political objectives. Democrats tapped into antiparty sentiments and touted their belief in American exceptionalism and their role as defenders of the Union. With Providence giving the country a man such as Jackson, whose patriotism and selfless service supposedly never waivered, the future of the nation seemed promising. Since Providence once again appeared to smile on the nation, Democrats could argue, the doctrine of Manifest Destiny should be implemented as political policy. The election results in 1844 appeared to show that Texas annexation, war with Mexico, and the expansionist mindset that benefitted slavery seemed to be aligned with the nation's divinely ordained future greatness and in tune with republican ideology. Ultimately, Jackson's supporters largely failed to place Jackson on a level with those of the founding generation. As historian Andrew Burstein notes, "as a prophet of national harmony Jackson failed because, unlike Adams and Jefferson, his partisan identity could never be shed. ${ }^{, 93}$ Indeed, Democratic initiatives could not completely overshadow historical memory. Despite the rise of American democracy under Jackson's tenure, citizens still sought "great men" who put the nation before political parties, and a political culture that was free from the demagoguery and factions that appeared to plague politics in the 1840s. Jackson's partisan battles remained fresh in public memories for those who were not members of the Democratic faithful.

Just four years after the perceived affirmation of Democratic initiatives, the Democrats came under attack by a reconstituted third party. By 1848, much of the Liberty Party had fused with disgruntled northern Democrats who wanted to prohibit

\footnotetext{
${ }^{93}$ Burstein, "Immortalizing the Founding Fathers: The Excess of Public Eulogy," in Mortal Remains, 106.
} 
slavery from entering western territory and advocated for a Free Soil movement. ${ }^{94}$

Though Democrats retained their base better than the Whigs, the signs of political

bloodletting for both parties became apparent as citizens continued to believe they were shackled by party leaders and not liberated by partisan politics.

The sermons and eulogies spoken and published in response to the deaths of William Henry Harrison and Andrew Jackson expose a dimension of antebellum politics not often examined through traditional approaches to political history. The commemoration of national leaders held an important role in sustaining and defining America's republican experiment. Harrison's unexpected death wrought a fissure in this process and brought antiparty and antislavery concerns about the nation's future to the forefront. The democratic system that fostered these sins, according to these evangelical eulogists, needed eradication, and many citizens paradoxically worked to do so through ideologically focused third parties. These concerns doomed the Whigs, who tried desperately to keep their party together despite having antiparty sentiments within the party. Democrats had greater comfort using democratic language. They proved savvier with antiparty rhetoric and used their majority position and the death of their leader to endorse their party through the promotion of exceptional rhetoric and a message of cohesion. Democrats played off antiparty sentiment and used memories created about Jackson to assuage fears and speak glowingly about America's future. In doing so, Democrats sought to undercut other parties as legitimate opposition and to garner support for their political positions that favored slavery. While Democrats were more successful

\footnotetext{
${ }^{94}$ For more on the Free Soil movement, see: Eric Foner, Free Soil, Free Labor, Free Men: The Ideology of the Republican Party before the Civil War (New York: Oxford University Press, 1970). Foner's work is a groundbreaking study focusing on Republican ideology in the 1850s, and in particular, their focus on economic reasoning for keeping slavery out of the western territories.
} 
than the Whigs at holding together party support, they would eventually face a reckoning, as increasing numbers of citizens no longer tolerated the ideals of any party that appeared to compromise the republican virtue of the nation.

Orations by the eulogizing class after the deaths of Harrison and Jackson illuminated the tensions in the cultural act of eulogy. Democracy was a constant struggle between political interests, and eulogists tried to influence democratic politics. Eulogists condemned democratic political culture even as sought power through it. The concerns that eulogists raised after Harrison's death appeared to be coming to fruition with Polk's election in 1844, and Democrats sought to calm those fears by making memories of Jackson that fit within the antiparty complexion of the political culture. When John Quincy Adams and John C. Calhoun died in 1848 and 1850, respectively, eulogists again reacted to contemporary political issues in their orations and sought to restrain the unsavory aspects of democratic culture that challenged the republican values they promoted. 


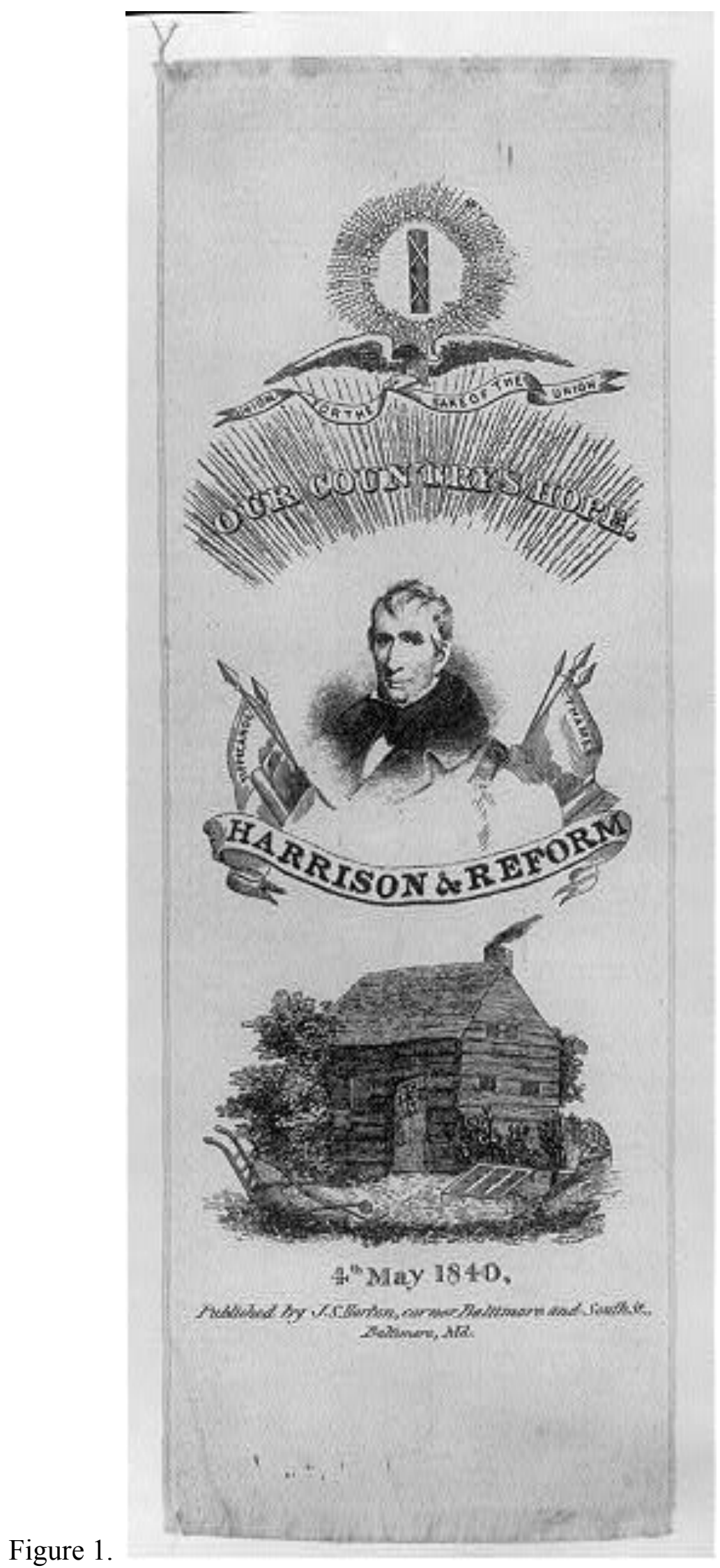


Figure 2

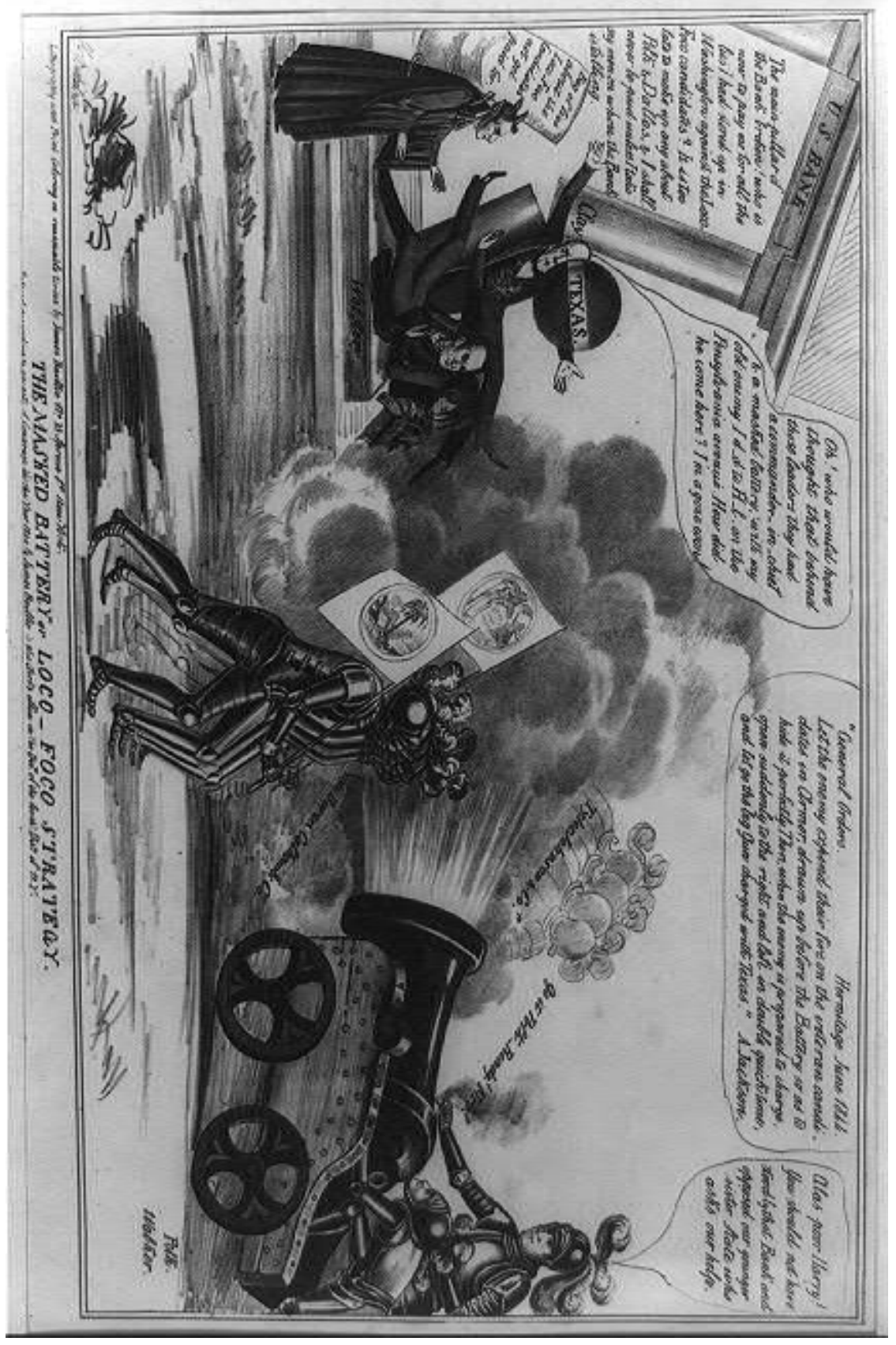


Figure 3

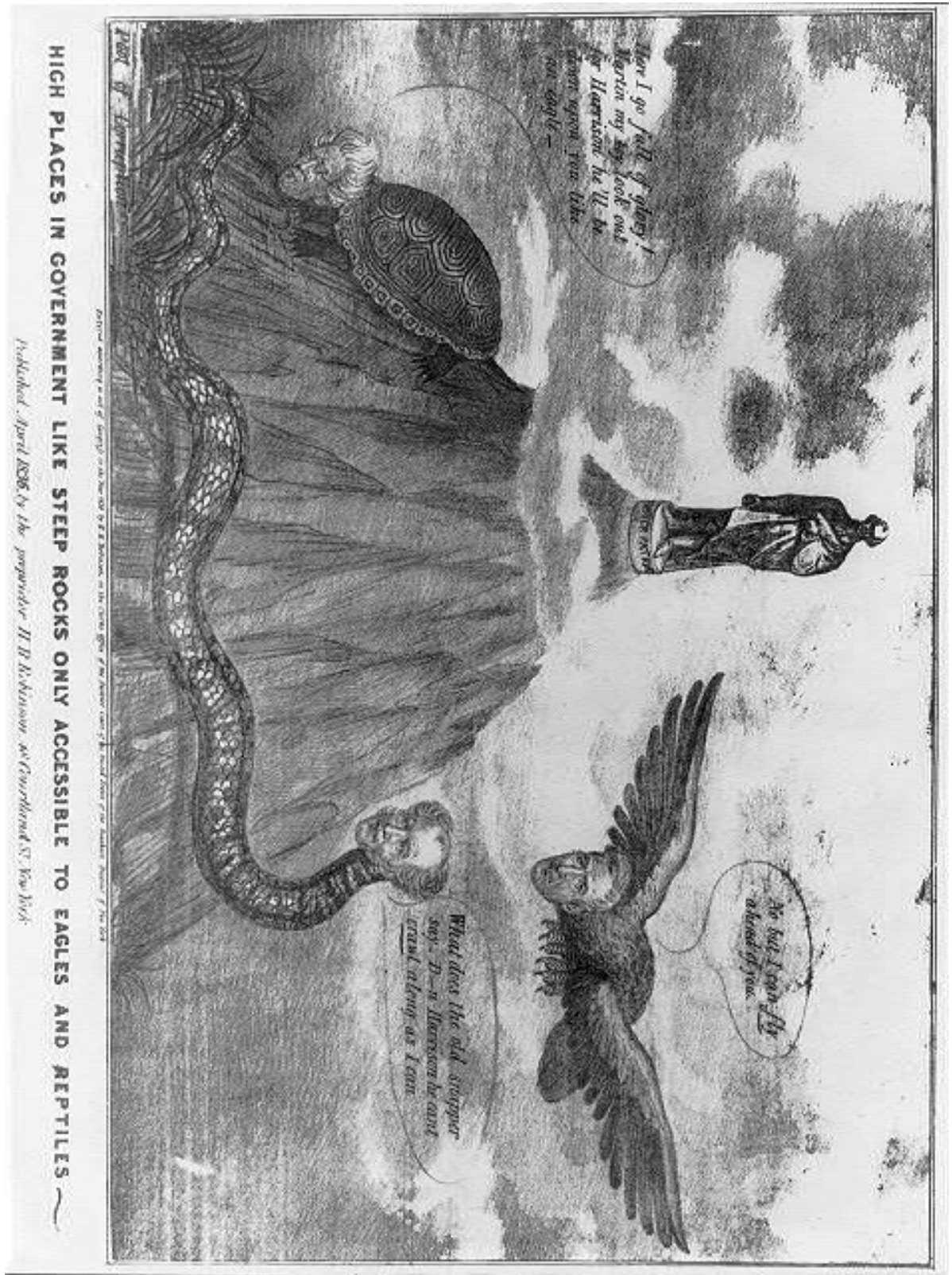


Figure 4.

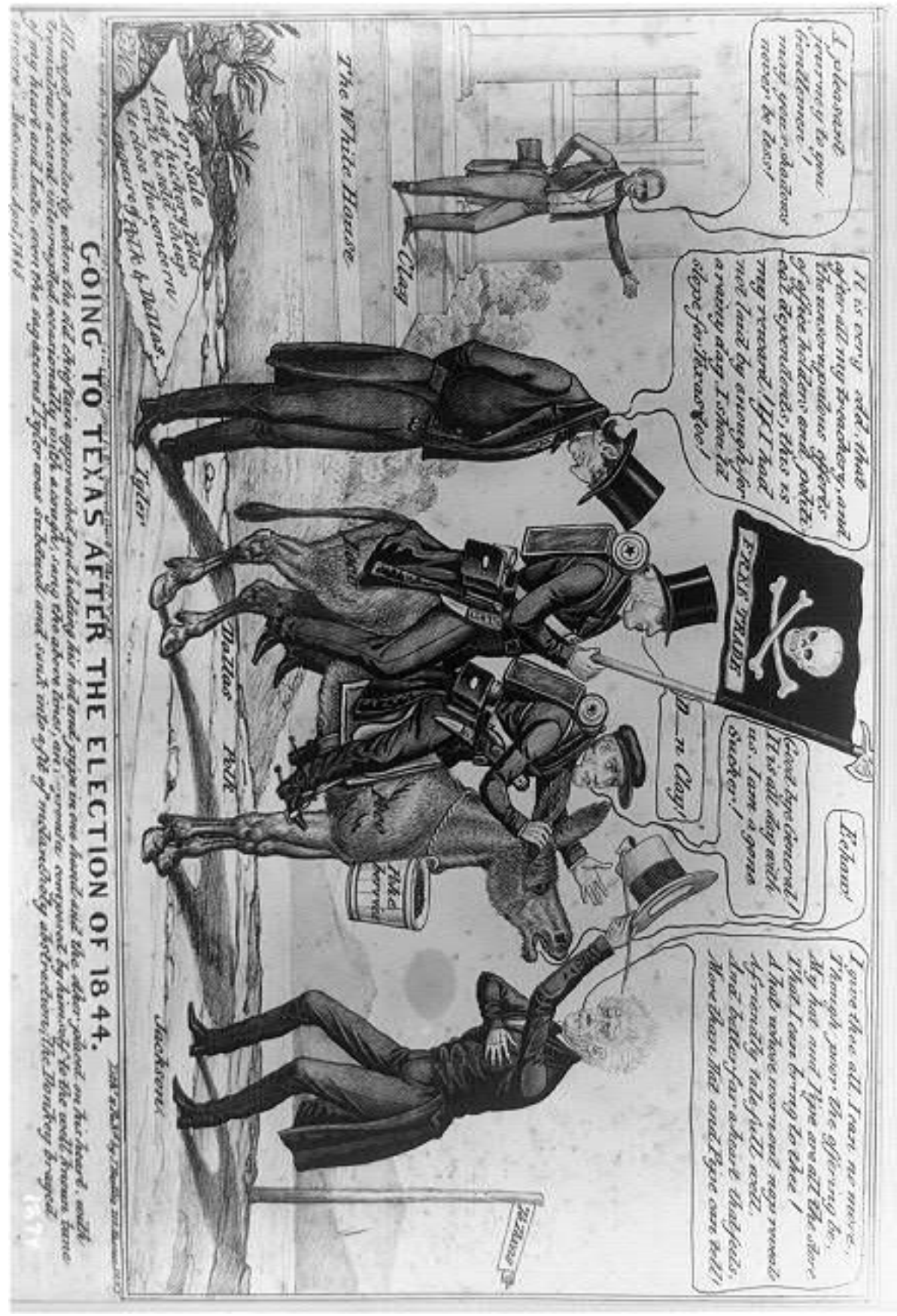


Figure 5.

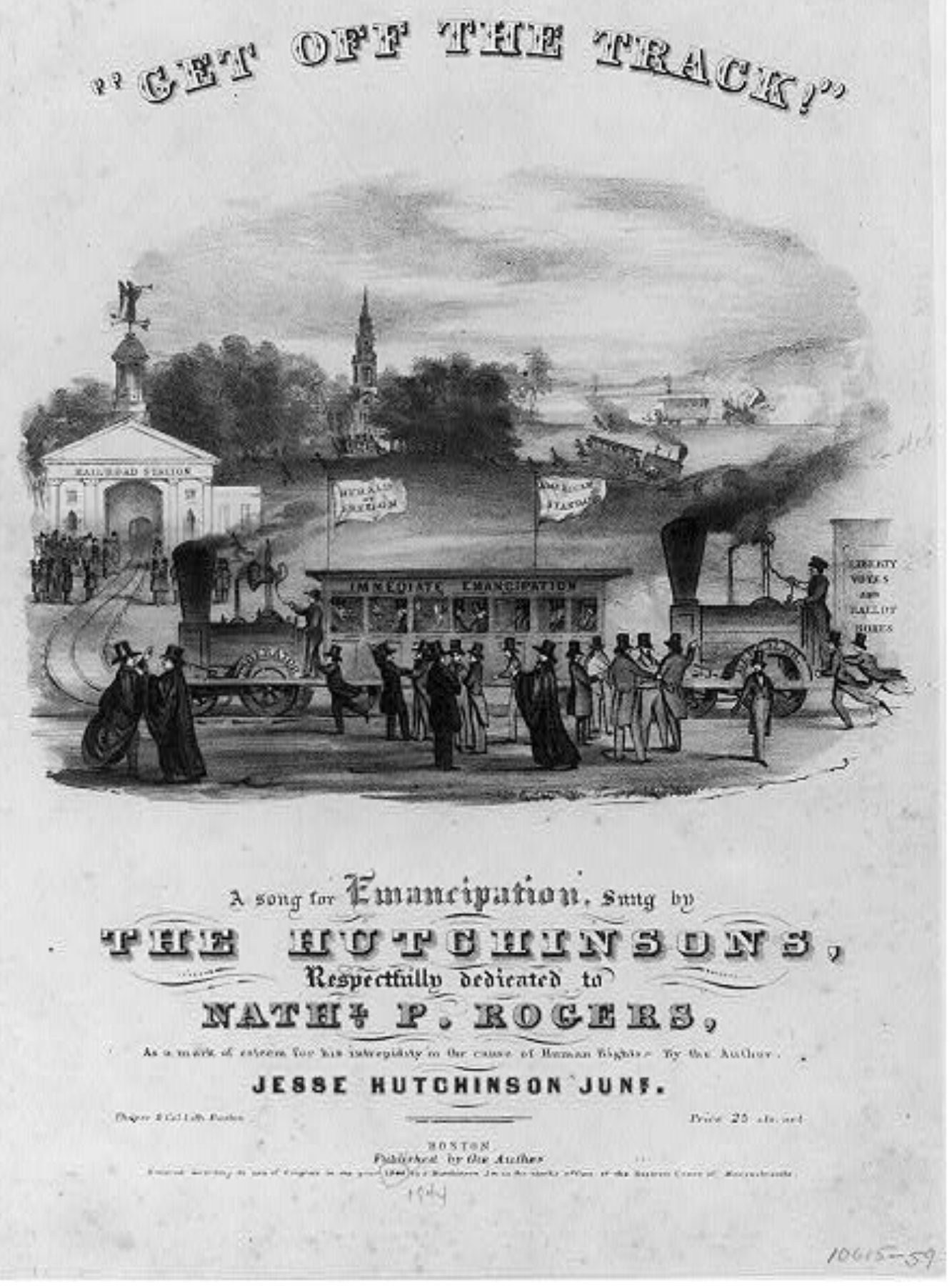




\section{Chapter 3:}

\section{"Thought Governs, Not Numbers": Minority Rights and the Commemoration of John Quincy Adams and John C. Calhoun}

As the war with Mexico concluded in February 1848, the House of

Representatives thought the time was appropriate to honor American generals for the victory. Amid an emphatic round of "ayes" throughout the House in support of the measure, a "no" emerged. In his last act of defiance, John Quincy Adams voiced his displeasure with Congress over the decision to go to war with Mexico. Soon after, Adams collapsed as he tried to stand at his desk, and congressmen quickly helped him to a couch that was brought onto the House floor. Adams slipped into a coma and passed away two days later on February 23, 1848. To many, Adams's death in the Capitol was a fitting end for a man who spent decades fighting political battles on the House floor; as had been the case throughout those years, his last course of action was standing up for his convictions despite going against the rest of Congress. Eulogists throughout the North remembered Adams as a nonpartisan defender of constitutional rights that increasingly came under threat by demagogues in the 1830s and 1840s. They highlighted his defense of the right of petition and connection to the Era of Good Feelings, a period that supposedly lacked political factions, in order to stress the necessity of republican virtue within the contentious political culture in the late 1840s that saw American expansion threaten the country's balance of power. ${ }^{1}$

\footnotetext{
${ }^{1}$ Harlow Giles Unger, John Quincy Adams (Boston: Da Capo Press, 2012), 308-310; William Lee Miller, Arguing About Slavery: John Quincy Adams and the Great Battle in the United States Congress (New York: Vintage Books, 1995), 458-459. For more detail on the Mexican War, the antiwar movement, and its broader influence on American politics, see: Amy S. Greenberg, A Wicked War: Polk, Clay, Lincoln and the 1846 U.S. Invasion of Mexico (New York: Knopff, 2013). For the viewpoint of the Mexican perspective
} 
The day after Adams's death, orations in Congress by Whigs and Democrats promoted national unity in an attempt to appear beyond partisan divisions caused by Texas annexation and the war with Mexico. Remembering Adams's long career and attachment with the Revolutionary era became a time for national mourning, especially as southerners in Congress gave passionate, yet generic, eulogies. However, beyond the walls of Congress, a eulogizing class of clergymen, lawyers, politicians, and educators in the North participated in a democratic process of public persuasion to offer multiple perspectives on Adams's legacy and to warn their listeners about the nation's future. The eulogizing class used Adams's passing not only to mourn his loss but also to obscure the complexity of Adams's politics in order to speak of the ill effects of democracy and to praise republican virtue.

To northern eulogists, John Quincy Adams stood in stark contrast to the democratic culture that changed the political landscape. His personality and demeanor represented an era that appeared to be fading away with the movement toward white manhood suffrage and the rise of the two-party system. Adams's death became an opportunity both to remind "the people" about what made a "great man" and to warn of demagoguery and partisanship that threatened respectable politics. Former president of Middlebury College and Chaplain of the Twenty-Sixth U.S Congress, Joshua Bates, used Adams's death to caution his contemporaries about their corrosive style of politics. "For the most elevated rank and the most honorable titles are often assumed by men of the lowest minds and vilest character," he bemoaned to his congregation in Dudley, Massachusetts, and continued to note, "not unfrequently [sic] the highest civil offices are

of the war, see: Timothy J. Henderson, A Glorious Defeat: Mexico and its War with the United States (New York: Hill and Wang, 2007). 
conferred on the weak and the wicked." While such rhetoric often denounced hereditary governments, Bates made sure to point out these flaws in democracies as well. He contended that in elective states selfish politicians and party spirit often produced the same results. Ultimately, Bates believed that men lacking moral and religious principles often filled high places in civil society. The lack of statesmen reflected negatively on the electors, and citizens needed to be conscious of unqualified individuals indulging the masses in order to gain votes. He believed Adams transcended this regression from republican virtue. Adams was a "great man" and used his moral and intellectual greatness for public good rather than becoming a "selfish demagogue" aspiring to power. ${ }^{2}$

Eulogists tried to shape public perception by promoting a political culture that had antidemocratic undertones and looked at political parties with skepticism. By valorizing Adams's attributes, eulogists emphasized that citizens must respect republican virtue, human rights, and protection of the constitution above all other considerations. Contemporary issues had a large influence on the contents of the eulogies. In particular, Adams's career in the House received a great deal of attention. His fight for the right of petition and support in favor of the Africans on the Amistad gave supporters an example of a man going against the current of popular thought in Congress and willing to take a principled stand. Eulogists obscured the democratic nature of petitioning in order to portray his actions as defending republican virtue rather than establishing a more democratic culture. Although eulogists promoted Adams as a nonpartisan, orations after his death had a partisan tone. Eulogists voiced frustration with the outcome of the

\footnotetext{
${ }^{2}$ Joshua Bates, A Discourse on the Character, Public Services, and Death, of John Quincy Adams (Worchester: Samuel Chism, 1848), 4, 7. Information regarding Joshua Bates can be found in: John J. Duffy, Samuel B. Hand, Ralph H. Orth, Vermont Encyclopedia (Hanover: University Press of New England, 2003), 50.
} 
Election of 1844 by criticizing Democratic President James K. Polk, the Mexican War, and the political pandering to slave owners. Yet, the orations were not simply just another partisan tool in the midst of bitter partisanship of the antebellum era. They also rejected what the Democrats, and to a lesser extent the Whigs, did to the nation. Eulogists against the war were not against the war and territorial expansion because they were Whigs; they were against it because it violated their values and was the result of a political system that had moved too far away from its republican origins.

Southern eulogists similarly warned of the culture's deviation from its republican roots when they mourned the loss of John C. Calhoun. His death on March 31, 1850 came at the height of sectional debates regarding territorial expansion and the future of slavery. Influential lawyers, politicians, educators, and clergymen delivered orations in South Carolina while citizens in the state contemplated the possibility of disunion. Eulogists attempted to prepare their audiences for future disunion by laying the groundwork for what would make it necessary. They used Calhoun's political ideology to deliver screeds against broader democratic participation in their orations. In doing so, they reinforced the righteousness of slavery as an American institution through their advocacy of the rights of the minority against the majority and through a conservative defense of the federal constitution.

Orators eulogizing Calhoun bolstered antidemocratic and nonpartisan impulses that ran particularly high throughout South Carolina. While concerns about democracy and partisan strife were prevalent throughout the country, they were extreme in South Carolina. Reverend James W. Miles had a warning for his listeners in St. Phillips Church in Charleston during his sermon after Calhoun's death. "The greatness of the Republican 
Statesman is not to be sought only in his high sense of national honor and his incorruptible devotion to the duties of the citizen," he proclaimed, while also acknowledging that those are common and lofty prerogatives of citizens. He contended that it was the distinction of a true statesmen to foresee dangers and corruption that threaten the national spirit. Miles, a professor at the College of Charleston and theological liberal, spent much of his sermon warning about the dangers of excessive democracy and articulating the reasons why republican citizens must consider disunion. ${ }^{3}$

In addition to the antidemocratic tone, eulogists promoted proslavery republicanism in order to make both moral and legal defenses of slavery as an American institution. They placed slavery in a context that would appeal to those in the state who did not own slaves. Eulogists argued that attacks on slavery from the North threatened a cherished institution sanctioned by God and the constitution, and heroically defended by Calhoun. Arguing for slavery as a national institution stressed the need for South Carolinians to embrace disunion if necessary. Disunion eulogists showed awareness for the importance of framing secession as patriotic. Calhoun's death enabled eulogists to praise him as a Union-saving man who understood the necessity of defending the rights of the South, and that disunion was a possibility in order to preserve the constitution. Calhoun's stance for Nullification, the Gag Order, and against Henry Clay's compromise of 1850 demonstrated his reputation as a statesman standing for what he perceived to be a noble purpose. While eulogists argued that Calhoun was a unionist, they also contended

\footnotetext{
${ }^{3}$ James. W. Miles, "The Discourse on the occasion of the Funeral of the Hon. John C. Calhoun, delivered under the appointment of the Joint Committee of the City Council and Citizens of Charleston, in St. Phillips Church, April 26, 1850," in John Peyre Thomas, ed., The Carolina Tribute to Calhoun (Columbia: Richard L. Bryan, 1857), 193. J.P. Thomas compiled a collection of Calhoun sermons and eulogies after his death in the hopes that it would "be accepted by them as a valued memento of a sad but cherished past." For more information on the religious beliefs of James W. Miles, see his collection of sermons published in 1849 titled: Philosophic Theology: or, Ultimate Grounds of All Religious Belief Based in Reason.
} 
that attacks on slavery threatened the federal constitution, thus northern threats to slavery justified disunion.

Orations following the deaths of John Quincy Adams and John C. Calhoun illuminate a complex political culture shaped by divisive issues of war, slavery, and territorial expansion. A eulogizing class attempted to use its societal influence to promote minority rights and form ideas about democracy through their orations. The orations for Adams and Calhoun demonstrate a common pattern of uneasiness with the rise of Jacksonian democracy and the two-party system that seemed to produce demagoguery and cultural decline. While southern eulogists more clearly spoke in antidemocratic tones, northern eulogists oscillated in their democratic beliefs, illuminating a struggle over what constituted democracy. Eulogists championed both men as advocates for minority rights who exemplified republican virtue. Yet, these two men offered contrasting visions for the future and a culture war over political ideology. Eulogists used Adams's plea for human rights and the freedom of speech to urge northerners to rally behind a set of attributes that would not tolerate morally bankrupt concessions to slaveholders. Eulogists for Calhoun defined slavery as a national institution and prepared their listeners for the possibility of disunion. They defended slavery by claiming its moral and social superiority over the North's "free society," highlighting protections for the institution in the federal constitution. They argued that vigilant southern citizens must defend the constitution against the tyrannical majority in the North and that disunion was a viable course of action to protect the proslavery document. Taken together, the deaths of Adams and Calhoun illuminate how present political developments caused a eulogizing class to look backward toward the Revolution and reinforce the concept of 
republican virtue, even though they disagreed about the ways that virtue manifested itself through Adams's and Calhoun's careers.

John Quincy Adams made history when he answered the call from his hometown and became a congressman after serving one term as President of the United States. Despite a long and distinguished career, it was in the post-presidential period in the House that he became a leading force and controversial figure in advancing a liberal vision of the constitution for human rights, freedom of speech, and internal improvements by the federal government. Adams championed democratic initiatives such as the right of petition not only for white men but also for women and minorities as well. While some of his policies promoted democratic rights, he also represented an age preceding the second party system. His presidency was the last before Andrew Jackson's two terms oversaw the growth of American democracy and the second party system. Adams's supposed republican leadership provided antiparty Whigs with an example of a man who did not hesitate to fight against party factions and who was not swayed by public clamor. For some in Congress, his passing represented an opportunity to mend the divisions caused by opposition to the war with Mexico. The day after his death, several congressmen delivered orations to cut against the democratic impulses of the political culture and silence the ideological battles that Adams had waged throughout his career. ${ }^{4}$

Southern Democrats passionately delivered eulogies for Adams, a man whom they previously tried to censure for his controversial positions. South Carolinian and Democrat Isaac Holmes spoke with grandeur, yet his eulogy consisted mostly of

\footnotetext{
${ }^{4}$ For more on the last sickness and death of John Quincy Adams, along with on the procession of his corpse to Boston and his funeral, see: The Adams Memorial; Containing a Sketch of John Adams, the Elder, Together With the Life, Character, Public Services, Last Sickness, Death, and Funeral Obsequies of the Late Venerable John Quincy Adams (Boston: J.B. Hall, 1848).
} 
platitudes about Adams's career and the mourning of his death. Holmes touched upon the commonalities and shared grief between South Carolina and Massachusetts. Ultimately, despite the splendor in which he spoke, Holmes's eulogy had little substance regarding Adams's career. At its core, Holmes's oration merely acknowledged Adams's various positions and that he had passed away. ${ }^{5}$ Southern Democrats James McDowell and Thomas Hart Benton also delivered brief orations that promoted national unity. Their words focused on summarizing Adams's career and praising his devotion to the country. Orators neglected to mention the multiple attempts to censure Adams, or his heated battles in the House, which usually were in opposition to southerners and Democrats. ${ }^{6}$ Fellow Massachusetts native and Speaker of the House of Representatives Robert C. Winthrop also spoke briefly in honor of Adams. Although he hailed from the same state and was a Whig, Winthrop and Adams often clashed on issues. As did many eulogists, Winthrop mentioned how Adams died almost on the same day as George Washington's birthday, and then he praised Adams for his long career and public service. Winthrop wielded his power in the House and chose not to call upon Joshua Giddings, Adams's close friend and protégé, to speak, nor did any antislavery advocates or abolitionists have a voice in the congressional orations. Winthrop's slight toward Giddings resulted from animosity between the two, which originated from ideological

\footnotetext{
${ }^{5}$ Token of a Nation's Sorrow. Addresses in the Congress of the United States, and Funeral Solemnities on the Death of John Quincy Adams, who died in the Capitol at Washington, on Wednesday Evening, February 23, 1848. Second Edition (Washington: J. and G.S. Gideon, 1848), 10. Holmes stressed that South Carolina shared in the mourning with Massachusetts. "The mingled tones of sorrow, like the voice of many waters, have come unto us from a sister state," he began, and stated that South Carolina also has mourned for their honored sons.

${ }^{6}$ The orations by James McDowell and Thomas Hart Benton can also be found in Token of a Nation's Sorrow. For an example of a eulogy delivered by a southerner not in Congress, see Judson's Crane's "Address: Delivered at the Request of the Military and Citizens of Richmond in Commemoration of the Life and Services of John Quincy Adams, March 21 ${ }^{\text {st }}$, 1848" which was reprinted in The Southern Literary Messenger on May 18, 1848. In his oration, Crane contends that Adams was not actually against slavery and that the accusation that he was remained a blemish on his career.
} 
wrangling over slavery while both were in the House. Winthrop still held political grudges when he appointed the congressional funeral entourage to return Adams's corpse to Boston, and he purposely excluded Giddings. Again, in an attempt to promote national unity, southerners and political adversaries such as John C. Calhoun, Roger B. Taney, and Isaac Holmes were a part of the Congressional Escort Committee. ${ }^{7}$

The tone of national unity continued as Adams's body reached Boston. Mayor Josiah Quincy welcomed the southern congressmen at a commemoration in Faneuil Hall, and pledged that if there came a time when the Union was weakened, they would "remember that our sister states sympathized with us in our grief as readily as their fathers rushed to our assistance in peril. ${ }^{18}$ The conciliatory nature of the commemoration continued after Quincy's speech sought to bind the sections together through a shared Revolutionary heritage. William P. Lunt, Unitarian Minister of United First Parish Church, where the Adams family attended, gave the sermon at Adams's funeral. He echoed the conciliatory nature of the eulogies in Congress and speech of the mayor. Lunt skipped over Adams's career in the House and left out Adams's fight for the right of petition, the Africans on the Amistad, and opposition to the Mexican War. He simply consigned Adams's seventeen years in the House by stating, "In 1831, he once more put on the harness, appeared before the country and the world in a new field of action, and commenced what, on many accounts, may well be regarded as the most remarkable period of his career." Much of what made Adams's career remarkable, however, was his

\footnotetext{
${ }^{7}$ Miller, Arguing About Slavery, 459-461; James Brewer Stewart, Joshua R. Giddings and the Tactics of Radical Politics (Cleveland: Case Western Reserve University, 1970), 150; Lynn Hudson Parsons, "The 'splendid Pageant': Observations on the Death of John Quincy Adams," The New England Quarterly 53 (1980): 471.

${ }^{8}$ Parsons, "The 'splendid Pageant,"” 471-472. Parsons also examines the meaning of eulogies delivered for John Quincy Adams. He similarly views a contrast between orations in Congress and those from clergymen. He argues Adams's death provided the opportunity to reaffirm both Puritan religion and Yankee culture.
} 
struggle against the southern politicians attending the funeral. ${ }^{9}$ At the end of his sermon, Lunt addressed the southerners who escorted Adams's body: "We thank you for your labor of love," he told the southern politicians. "From each State and Territory of our glorious Union, you have gathered here on this occasion, as if to fulfill to the letter, the language of one with whom you are associated in public duties," he declared. Lunt romantically looked back at the nation's history and marveled at the country that Adams witnessed develop. Indeed, Adams's career in the official orations told a story of national unity that rescued the regions and parties from the divisiveness of the Mexican War and the impending Election of 1848, yet it excluded the democratic nature of his politics that won him the admiration of many northerners. ${ }^{10}$

The ability of governing bodies to advance national unity by silencing sectional issues eroded after Adams's funeral. At the request of the Legislature of Massachusetts, Bay State native Edward Everett delivered a eulogy in Faneuil Hall, roughly a month after the funeral for Adams. Everett possessed many of the attributes of those within the eulogizing class. Harvard educated, he spent time as a minister, educator, writer, and politician. Known for his oratorical skills, he held a prominent position within New England politics and society. ${ }^{11}$ Everett acknowledged the national mourning that had preceded his eulogy and mentioned the respect and veneration that men of all parties gave Adams as they united in his honor. Everett noted the meaning of orations for future

\footnotetext{
${ }^{9}$ William P. Lunt, A Discourse Delivered in Quincy, March 11, 1848, at the Interment of John Quincy Adams (Boston: Dutton and Wentworth State Printers, 1848), 28.

${ }^{10}$ Lunt, A Discourse Delivered in Quincy, 40, 44

${ }^{11}$ For a biographical sketch of Edward Everett's life and career, see: Irving H. Bartlett, "Edward Everett Reconsidered," The New England Quarterly 69, (September 1996): 426-460.
} 
generations, and hoped they would learn from the laborious and eventful life Adams lived. $^{12}$

Everett acknowledged that his words of tribute could not deviate into controversial political topics. He recognized the legislature's desire to avoid rekindling political animosities. "I come, at your request, to strew flowers upon the grave of an illustrious fellow-citizen; not to dig there, with hateful assiduity, for roots of bitterness," he admitted while discussing the purpose of the occasion. He promised not to reignite controversial issues and gave further assurance not to "mingle ourselves in the party struggles of the day," in order to subdue the passion that would arise if he discussed contentious issues. ${ }^{13}$ Everett, however, could not overlook what many Americans saw as Adams's most worthy accomplishments in order to promote national conciliation. $\mathrm{He}$ preemptively warned, "I do not forget the limits prescribed to me by the circumstances under which I speak," yet believed that it would be an injustice to both Adams and future generations if he did not touch upon Adams's views on slavery. ${ }^{14}$

Everett reinforced Adams's stance on the institution of slavery to solidify his own antislavery credentials. Early in his career, Everett received criticism for a speech while in the House that appeared to endorse slavery. To squelch the criticism, Everett emphasized his opposition to the Atlantic Slave Trade. ${ }^{15} \mathrm{He}$ associated Adams's view on slavery with his own. After mentioning Adams's denouncement of the slave trade, Everett then remarked that while Britain was responsible for slavery in America, a

\footnotetext{
${ }^{12}$ Edward Everett, A Eulogy on the Life and Character of John Quincy Adams, Delivered at the Request of the Legislature of Massachusetts, in Faneuil Hall (Boston: Dutton and Wentworth, 1848), 9.

${ }^{13}$ Ibid., 10-11.

${ }^{14}$ Ibid., 46.

${ }^{15}$ Bartlett, "Edward Everett Reconsidered," 436-437; Paul Revere Frothingham, Edward Everett (Boston: Houghton Mifflin, 1925), 106-108.
} 
movement within Britain ended the institution without it threatening public peace. Yet, despite a growing movement to end slavery in the United States, Everett thought it important to state that Adams did not align with “organized agitation.” Adams's convictions for the right of petition made him a great statesman. "No strength or violence of opposition, or menaces of danger, deterred him from the office he had assumed," asserted Everett, who focused on Adams's belief in the sanctity of the rights given to citizens in the constitution. Adams never wavered in its defense, regardless of the opposition. ${ }^{16}$ Indeed, Everett's eulogy reads like a guidebook for northern politicians. While he brings up the right of petition, Everett stops short of denouncing slavery and those who support it, and instead focuses on Adams's legal defense of northern rights. To Everett, Adams's stance on petitioning was a sign of his republican virtue, rather than of his endorsement of democratic political culture. Adams embodied the moral courage needed to stand against political parties and to defend northerners against threats to their constitutional rights. Yet, Everett acknowledged that taking such a stand happens at a cost in democratic government and that exhibiting real independence in difficult times usually comes with great personal sacrifices and violent collisions. ${ }^{17}$

While national politicians largely silenced sectional and political disputes for the sake of national conciliation, some influential northerners disregarded attempts at national unity and used Adams's death to warn "the people" about the dangers awaiting the North unless an active citizenry regain their republican consciousness. Unitarian biblical scholar and Reverend Abiel Abbot Livermore believed he was taking part in an important act of remembrance during his sermon for Adams. When speaking to his

\footnotetext{
${ }^{16}$ Everett, A Eulogy on the Life and Character of John Quincy Adams 49.

${ }^{17}$ Ibid., 61.
} 
congregation in Keene, New Hampshire, Livermore did not believe the purpose of his sermon was to repeat the eulogies of others or glorify the dead, but rather to teach lessons through Adams's life and career. ${ }^{18}$ For Livermore, Adams's career stood in contrast to a political culture that was disreputable. "This is an age of associations and majorities; we must not overlook the rights or the power of the few or the one. Thought governs, not numbers," Livermore reminded his listeners. The increasingly democratic culture caused politicians to pander to the masses for votes. According to Livermore, though, despite these changes to the political culture, strong-willed and intellectual men could still overcome the nature of mass politics. He supposed that while occasionally men are products of the times, the times could also be produced by great men. ${ }^{19}$

Adams represented an age of politics that had eroded with the rise of democracy. While politicians resorted to electioneering tactics and put parties above the best interests of the nation, Adams was the symbol of an age fading away. Livermore touted Adams as a "bold, independent, original mind, that did its own thinking, stood upon its own basis, and asked no man's consent to exist or act." The individuality that Adams possessed made him unique in a period of fierce partisanship. With the temptation of corruption in democratic politics, one could look to Adams and be assured that as a Christian statesman

\footnotetext{
${ }^{18}$ Many sermons delivered for Adams similarly stress that their purpose was not to praise or give false information about the deceased. For another example, Theodore Parker noted, "I am not to praise Mr. Adams simply because he is dead; what is wrong before his death is wrong after death. It is no merit to die - shall we tell lies about him because he is dead?" Clergymen stressed their supposed desire to remain neutral in interpreting the deceased, yet as the sermons illustrate, they still use the memory of the individual for political and cultural purposes. Theodore Parker, A Discourse Occasioned by the Death of John Quincy Adams: Delivered at the Melodeon in Boston, March 5, 1848 (Boston: Bela Marsh, 1848), 27.

${ }^{19}$ A.A. Livermore, The Ancient and Honorable Man: A Discourse Preached on the Occasion of the Death of Hon. John Quincy Adams, to the Unitarian Church and Congregation, Keene, N.H. on Sabbath Afternoon, March 5, 1848 (Keene: J.W. Prentiss \& Co., 1848), 4, 8. For similar sentiments touting Adams's statesmanship that was not influenced by parties or at times public opinion, see: A.F Perry, Eulogy on the Life and Character of John Quincy Adams, Delivered Before the Citizens of Columbus, Ohio, April 8, 1848 (Columbus: Ohio Press, 1848), 14.
} 
he would never put a party or self-interest above the nation. ${ }^{20}$ Livermore's words reflect the more traditional aversion to democracy, which ushered in a new type of voter who was deemed ill-equipped to vote during the revolutionary era. Unworthy voters posed a threat to the republic, and eulogists intended to influence public understanding of democracy by giving instructions on the qualities to look for in politicians. Elite southerners, of course, had long shared this sentiment and used such republican rhetoric when resisting Adams's attacks on the Gag Order. Yet, Adams's fight against the Gag Order was an effort to give those deemed unworthy to vote the right of free speech under the First Amendment.

Not surprisingly, there was a partisan tone to the orations because the republican virtue they promoted had several parallels with Whig values. After all, Adams was a Whig and although he was hesitant to align with any political party for much of his career, he, in his later years, identified himself as a Whig. Adams also agreed with the Whig Party on important national issues such as internal improvements, opposition to Texas annexation, and the war with Mexico. Eulogists spoke of current "days of political degeneracy," and their criticisms were oblique attacks on the Democratic Party. ${ }^{21}$ The Whigs formed in response to Jacksonian democracy, so it is no surprise that the coalition had antidemocratic leanings. However, even for eulogists aligning with the Whigs, the

\footnotetext{
${ }^{20}$ Ibid., 9. For similar sentiments on the rise of partisanship with democracy, see: Charles King, Eulogy upon John Quincy Adams, Prepared at the Request of the Corporate Authorities of the Borough of Elizabeth, and Delivered Before Them, on Wednesday Evening, April $5^{\text {th }}, 1858$ (Elizabethtown: E.

Sanderson, 1848). King praised Adams's presidential administration for being a national, rather than party, administration, which alluded to the rise of the two party system once Andrew Jackson defeated Adams in the Election of 1828 . He also obliquely criticized the Democratic Party for making the presidency a partisan office and for their use of patronage for loyalty party men.

${ }^{21}$ Parson, "The 'Splendid Pageant,"” 474. The quotation is from a sermon delivered on Adams by William Furness in Philadelphia; Timothy Walker, An Oration on the Life and Character of John Quincy Adams: Delivered Before the Citizens of Cincinnati, on the Twenty-second day of March 1848 (Cincinnati: J.F. Desilver, 1848), 17. Walker also stressed Adams being immune from "modern degeneracy."
} 
party was more accurately an antiparty coalition than a political party. Like other Whigs, eulogists longed for a return to a nostalgic past in which politics was supposedly more respectable. Regardless of political reality, Adams became a symbol of that nostalgia. While partisan politics had an influence on the orations, eulogists placed supreme emphasis on the values Adams supposedly exhibited regardless of party loyalty. That Whiggery became an avenue for some to try to capture those values and place them into politics continues to misdirect historians from seeing the antiparty complexion of the antebellum era. $^{22}$

Eulogizing Adams provided an opportunity to speak against the partisanship of the time and to promote a restoration of republican ideals. Although he was a Whig, Adams was revered for his detachment from political ties and citizens looked back longingly at his career as a rare example of a man not tied to a party. Adams received admiration for serving the public good and not personal ambition. His republican bearing was supposedly reminiscent of the Revolutionary era, in which intelligent men with integrity answered the call of duty to serve the nation at personal expense. With the rise of democracy, that vision of a statesman appeared to be less frequent. Before the Bar of Hamilton County, Ohio, William Greene spoke in an antidemocratic tone during his eulogy on Adams. Greene, who was educated at Brown University, moved to Cincinnati, to practice law and became a prominent member in society as a leading advocate for public schools and internal improvements. ${ }^{23}$ His eulogy was as much a condemnation of

\footnotetext{
${ }^{22}$ As Daniel Walker Howe observes, Whigs tended to think of themselves as nonpartisan defenders of reason against the passions of crowds, and Whigs prided themselves on being a coalition for issues rather than a party based on political patronage and degrading serious republicanism with electioneering tactics. Daniel Walker Howe, The Political Culture of the American Whigs (Chicago: The University of Chicago Press, 1979), 52-53.

${ }^{23}$ Henry Edward Turner, The Greene's of Warwick in Colonial History: Read Before the Rhode Island Historical Society, February 27, 1877, (Newport: Davis \& Pitman, 1877), 70.
} 
the current state of politics as it was of praising Adams's legacy. According to Greene, party association in a democracy caused men to focus on party objectives rather than being of useful service to the country. ${ }^{24}$

To Greene, the rise of the two-party system and Jacksonian democracy overpowered the ability of virtuous citizens to do their republican duties. Powerful political factions rejected men who would govern above partisanship and not pander for votes. He bemoaned that demagogues were "often found in the highest trusts of power" and remained there "because their identity with the party system to which they owe their elevation, renders them indispensable to its support. ${ }^{.25}$ Greene supposed, however, that Adams was an exception to the virulence of partisanship and demagoguery. There was almost no escape from the maliciousness of political parties, which "spares no man, however exalted in purity who stands in the way of its success." Yet, despite the sad state of politics, Greene believed that death freed Adams's legacy from becoming a partisan ploy, and now he was able to receive proper appreciation for his efforts as a republican statesman. These concerns are similar to those discussed by eulogists after the death of William Henry Harrison. People respected Adams's and Calhoun's virtue and antiparty credentials, and eulogists continued to emphasize those qualities by other deceased politicians during the antebellum era. Beyond antipartyism, though, Adams and Calhoun also fought for minority rights against the powers of a majority, and eulogists saw that as a premier virtue of both men. ${ }^{26}$

\footnotetext{
${ }^{24}$ William Greene, An Oration on the Life and Character of John Quincy Adams, Delivered at Cincinnati, 25 March, 1848, Before the Bar of Hamilton County, at their Request (Cincinnati: Cincinnati Chronicle, 1848), 9.

${ }^{25}$ Ibid.

${ }^{26}$ Ibid., 12-13.
} 
His republican traits allowed for comparisons between him and George

Washington. Many of the eulogists noted the coincidence of Adams dying close to Washington's birthday and hinted at the Divine meaning behind it, similarly to when Thomas Jefferson and John Adams died on the same day. William Henry Furness continued the connection between John Quincy Adams and George Washington by using the coincidence to advocate for human rights. He contended that the images of Washington and Adams now seemed linked together "to be faithful to the great cause of Human Rights, for which they lived, and to put back into the scabbard the sword which is dripping with the blood of a poor and defenceless [sic] nation." Even though Adams was never in the military, eulogists stressed that Adams still fought a noble struggle similar to Washington's in order to promote human rights and liberty. Connecting Adams to Washington was an attempt to make Adams a national figure and a man who advocated for the benefit of the entire nation, not just the North. ${ }^{27}$

Eulogists voiced frustration with "the people" who failed at their republican duties and allowed themselves to be deceived by fraudulent statesmen. Eulogists hoped that in the future, citizens would remember the values that Adams possessed and not be fooled by electioneering tactics and political humbuggery. ${ }^{28}$ Reverend Stedman W.

Hanks stressed Adams's character and nonpartisanship as an example of what to look for

\footnotetext{
${ }^{27}$ William Henry Furness, The Memory of the Just. A Discourse, Delivered in the First Congregational Unitarian Church, in Philadelphia, February 27, 1848 (Philadelphia: Crissy and Markley, 1848), 9. Throughout his sermon, Furness continued to connect the character, attributes, and governing of Washington and John Quincy Adams. In particular, he emphasized the nonpartisan spirit of both men.

${ }^{28}$ Eulogists showed concern for the future generations growing up in the democratic era. Reminiscences of Adams stressed the importance of improving the abilities of the citizens who vote. The District School Journal of the State of New York reprinted a sketch on Adams's life from the Massachusetts Common School Journal, which lamented, "Elective rulers reflect the character of the electors, as a mirror in the face of him who looks upon it. Would we have purer and more copious streams, we must have purer and more copious fountains." Skeptical of the citizenry to elect the correct officials in a democratic government, the Journal continued to argue, "What we need then, is, a better and wiser people," and to train future sons and daughters to be a wiser generation. The quotations can be found in: "John Quincy Adams," The District School Journal of the State of New York May 1848.
} 
in politicians. "He did not find his way to office by any of those petty tricks by which small men are raised to great places," he exclaimed of Adams. According to Hanks, Adams was a man who could not be bribed and was fearless when it came to doing what was right for the nation. ${ }^{29} \mathrm{He}$ also applauded Adams's self-restraint. Hanks praised Adams's political independence and refusal to degrade his character with such acts as dueling was a valuable lesson to "the people." Hanks warned, "If horse-racing, gambling, Sabbath-breaking, duelling, $[$ sic $]$ and slave-trading, are carried on by men who are the chosen rulers of the country, the people will go and do likewise." Hanks delivered a clear shot at party leaders Henry Clay and Andrew Jackson, who participated in such activities. Rather than viewing them as role models, they represented the cultural decline that democracy produced. These warnings by eulogists also established their desired limits to democratic political culture. Citizens had a responsibility to elect men of moral courage and high character, like Adams, in order save the country from further degeneracy. Hanks, like other eulogists who promoted similar sentiments, hoped to shape society through the values they preached and actions they denounced. ${ }^{30}$

Adams transcended the democratic culture represented by partisanship and made him a revered figure throughout the North. Adams was the last president before Andrew Jackson's presidency altered the political landscape by ushering in the second party system and moving closer to universal white manhood suffrage. With these changes came a continued frustration with the move away from traditional republicanism and

\footnotetext{
${ }^{29}$ Stedman W. Hanks, A Sermon on the Occasion of the Death of the Hon. John Quincy Adams, Preached at the John Street Congregational Church, in Lowell, March 5, 1848 (Lowell: W.H. Waldron, 1848), 11; For similar sentiments, see: Nathan Lord, A Eulogy on the Honorable John Quincy Adams, Delivered March 24, 1848, at the Request of the Students of Dartmouth College (Hanover: Dartmouth Press, 1848), 15-16. Lord argued that it was imperative for educated young men to study Adams's character. Lord believed that the virtues of the Founding Fathers were fading away, and the future of the nation depended on young men restoring republican virtue to a declining political culture.

${ }^{30}$ Ibid., 6-7.
} 
uneasiness with loyalty to political organizations. Antiparty spirit persisted throughout the nation, and Americans still heeded George Washington's warnings about the challenges party strife posed to national harmony. Adams's death marked the passing of a statesman who looked out for the best interests of the nation regardless of party affiliation, and that was a lesson that eulogists hoped to instill in their listeners. Joshua Bates hailed Adams's independence and courage to not be swayed by both political parties and the masses. "He was too conscientious and independent to be held in the trammels of party," Bates asserted. Bates acknowledged that at certain times parties tried to claim him as a member, but that Adams never completely identified with any. ${ }^{31}$ William Greene echoed those sentiments, proclaiming, "The spirit of integrity that pointed him to the right as a lover of his country, spurned the trammels that would bind him to a wrong as the follower of a party." ${ }^{, 32}$ Of course, Adams did identify with the Whigs particularly during the latter part of his career during the 1840 s, yet eulogists hoped to look beyond that association and to elevate him to a position above the aspects of democracy they found objectionable.

Adams's life provided an example of what made a "great man" and eulogists hoped "the people" would still emulate such figures. Eulogists argued that great men were rare, and that citizens must appreciate and learn from men who fit the description they extolled. Republican virtue made a great man to members of the eulogizing class, which fit more within the nostalgic conceptions of the Revolution. Stedman Hanks believed that great men were scarce throughout the nation. "In the midst of surrounding corruption it is extremely hard for a good man to rise by the suffrages of the people," he

\footnotetext{
${ }^{31}$ Bates, A Discourse on the Character, Public Services, and Death, of John Quincy Adams, 13.

${ }^{32}$ Greene, An Oration on the Life and Character of John Quincy Adams, 15.
} 
regretted. Hanks believed that the removal of great and good men from high offices of influence was a national calamity, and that increasingly men of low intelligence and corruptible values were elected into prominent positions. ${ }^{33}$ Theodore Parker likewise believed that American politics demanded greatness. A successful republican government required true manhood and intelligence out of its leaders if the government could truly be "of all, for all, and by all."34 Bates reiterated similar sentiments about "great men." Whigs spoke about Adams in similar terms as the Democrats used about Andrew Jackson. Adams's moral prowess was certainly a reason, yet his independence from political parties truly made him a great man. Adams illustrated the "character of decision, firmness, and moral courage, which constitutes a great man, acting as an independent republican," according to Bates. ${ }^{35}$ During a time when democracy supposedly flourished throughout the nation, eulogists urged the need for "great men" and a rejuvenation of republican spirit throughout "the people" to resist aspects of the democratic culture that threatened it.

Eulogists used Adams's career in order to shape northern conversations over divisive political issues. Northern orators, unlike eulogists in Congress who ignored controversial aspects of his career, instead emphasized moments that bolstered northern rights and an intolerance of slavery's corrosive influence. Eulogists used examples of Adams's famous stands in support of human rights and freedom of speech as an example of his courage. A.A. Livermore spoke in a militant tone regarding Adams's fight against supporters of slavery. While party men fallaciously compromised and shrunk from taking a noble stand against slavery, Adams stood firm, he contended. Honor and everlasting

\footnotetext{
${ }^{33}$ Hanks, A Sermon on the Occasion of the Death of the Hon. John Quincy Adams, 4-5.

${ }^{34}$ Parker, A Discourse Occasioned by the Death of John Quincy Adams, 10.

${ }^{35}$ Bates, A Discourse on the Character, Public Services, and Death, of John Quincy Adams, 14.
} 
fame belonged to Adams, "who was the soldier of the right, and who fought for the right, though a whole country or a whole world might be up in arms against him!" He believed Adams was a Christian statesman who did not bow to a Slave Power or the whims of the public. He stood for republican virtue and fought an honorable war against the institution of slavery. ${ }^{36}$

Eulogists admired Adams's clashes with slavery as a constitutional and republican struggle. Regardless of the particular eulogist's moral opinion of slavery, orations highlighted Adams's position while differentiating it from the abolitionist cause so as not to discredit his opinions. His congressional battles were over fundamental rights, not the work of extremists within the abolitionist movement. Reverend Frederick A. Farley emphasized Adams's nonpartisanship and republican virtue before embarking on his positions on slavery. Promoting Adams's "unquestioned honesty and integrity" and freedom from all partisanship thus made his political positions more legitimate and sincere than if he merely promoted the position of a particular party or group. "I do not understand Adams to have, by any means, approved all the sentiments, much less all the measures of the Abolitionists, upon this question," noted Farley regarding the slavery question. Because eulogists wanted to sway public opinion, it was essential to differentiate Adams from extremist groups on the issue. ${ }^{37}$ Farley, a Harvard graduate, practiced law before studying at the Harvard Divinity School. He became a pastor for the First Congregational Unitarian Society and had a large congregation at his Brooklyn

\footnotetext{
${ }^{36}$ Livermore, The Ancient and Honorable Man, 17.

${ }^{37}$ Frederick A. Farley, A Discourse on the Life and Character of John Quincy Adams, Preached at the Church of the Saviour, on Sunday Evening, March 5, 1848 (Brooklyn: Lees \& Foulkes, 1848), 6-7.
} 
church. ${ }^{38} \mathrm{He}$ presented a rational and legalistic description of Adams's views, and asserted that no legal position of Adams was more heroic than his defense for the right of petition. He contended that Adams believed that "the people" had an inalienable right to be heard, and he insisted that remain upheld. Farley endorsed a critical component to democracy. Like other eulogists, he did not deliver a complete condemnation of democratic ideals. Rather, eulogists obscured aspects of democracy to fit within their desire for a republican government. Citizens had the right to free speech under the constitution, not because of a longstanding commitment to democracy. While many citizens viewed petitioning as a quintessential aspect of democracy, eulogists emphasized the republican virtue of Adams's stand for those rights. ${ }^{39}$

Adams's fight for the right of petition embodied a broader struggle over what constituted democracy. Texas annexation and debates about the spread of slavery instigated a surge in petitions to Congress. Abolitionist and antislavery groups signed petitions and urged Congress against supporting policies that facilitated the spread of slavery through Texas annexation. The House of Representatives, coaxed by southerners, responded to these petitions with a gag rule disallowing the discussion of petitions about slavery. Though he was not an abolitionist, Adams ardently supported the right of petitioners. Adams contended that the suppression of petitions regarding the annexation of Texas was a design of proslavery forces. ${ }^{40}$ Eulogists highlighted Adams's struggle in order to galvanize northerners to resist attempts by a Slave Power to take away

\footnotetext{
${ }^{38}$ Louis Ruchames, ed., The Letters of William Lloyd Garrison, Volume II: A House Dividing Against Itself, 1836-1840 (Cambridge: Harvard University Press, 1971), 131.

${ }^{39}$ Farley, A Discourse on the Life and Character of John Quincy Adams, 7; for similar sentiments, see: Lord, A Eulogy on the Honorable John Quincy Adams, 12-16.

${ }^{40}$ Elizabeth R. Varon, Disunion! The Coming of the American Civil War, 1789-1859 (Chapel Hill: University of North Carolina Press, 2008), 128.
} 
democratic rights guaranteed under the constitution. Interpretation of the gag rule became an ideological battleground over constitutional rights between supporters of property rights and of free speech. Farley commended Adams for fighting for those sacred rights despite pressure from Congress, and at times, the public. "He presented the petitionsand when he persisted in presenting them, the torrent of opposition came thundering down on his seemingly devoted head," Farley applauded about Adams's independence and courage. He believed that a "sublimer, more heroic spectacle, was never exhibited in the halls of Legislation of this or of any land." It was Adams who took the initiative in opposing Texas and upheld his republican duty to protect the common good and fundamental rights that increasingly came under threat by proslavery forces. ${ }^{41}$

The controversy over the right of petition paralleled the struggles of the American Revolution and the republican ideology that drove statesmen of that era. Eulogists focused on Adams's ideological battle against party factions rather than the democratic nature of petitioning. Just as Revolutionary heroes stood up for the rights of citizens, so did Adams who faced overwhelming opposition. Adams fought for minority interests against a congressional majority that favored the gag rule. Even though the First Amendment had democratic intentions, it still needed "great men" to protect those rights. Political parties' shying away from courageous stands was another example of how partisanship and the two-party system degraded politics. Eulogists argued Adams carried on the Revolutionary spirit throughout the struggle. Believing that Adams's defense of petition was the crowning moment of his career, William Greene asserted that it awoke the "Genius of the American Revolution" to renew its vows of liberty. He continued, "There was the Spirit of Seventy-Six, gone away awhile to Heaven with the

\footnotetext{
${ }^{41}$ Farley, A Discourse on the Life and Character of John Quincy Adams, 7-9.
} 
Revolutionary Fathers, now come back again to earth, to renew its battles in the cause of American Independence.” The growing sectional agitation between the North and South over slavery often led to both sides looking to the American Revolution for justification of their positions. Eulogists likewise used Adams's connection with the Revolutionary generation to give the ideological basis for his stance on slavery. ${ }^{42}$

Defense of the right of petition as a legal and moral right counteracted similar arguments by southerners and conservative northerners defending slavery. Eulogists argued that at the heart of Adams's struggles with Congress were northern ideals that he defended against demagogues on both of the ideological ends of the slavery issue. Not only did Adams defend liberty and human rights, but he also stood up for northerners who believed their rights were under attack by a democratic system tainted by proslavery influences. Although they had opposing views on slavery, Adams's eulogists echoed Calhoun's eulogists by voicing concerns that a majority had circumscribed the rights of minorities. While speaking at the Melodeon in Boston, Theodore Parker contended that Adams "was a Northern man with Northern habits, methods, and opinions." He continued to use Adams's death in order to contrast the political cultures in the North and South. In the North, he opined, prominent men did not seek out a career in politics, and northern politicians typically had previous careers as lawyers, mechanics, clergymen, farmers, and merchants. In the South, however, slavery shaped political quests for power. Because the South put emphasis on political control, southerners succeeded in hijacking the meaning of the Revolution in order to protect slavery. "The North made the Revolution, furnished the men, the money, the ideas, and the occasion for putting them into form," Parker

\footnotetext{
${ }^{42}$ Greene, An Oration on the Life and Character of John Quincy Adams, 16. For similar sentiments, see: R.C. Waterson, Discourse on the Life and Character of John Quincy Adams; Delivered the Sabbath after his Death, Feb. 27, 1848, at the Church of the Saviour (Boston: Freeman and Bolles, 1848), 16.
} 
argued, yet lamented that when making the Constitution, the southern demagogues "outtalked" the North, leaving the region to "not only consent to slavery, but allowed it to be represented in congress." Without educated citizens, a democratic government was doomed for failure, and slavery played a critical component in that. Both sides of the slavery issue perceived democracy as dangerous because of the institution. Parker bemoaned that the southern aristocracy ruled the "Northern masses" and both major political parties. Democracy was failing to protect the rights of northerners. ${ }^{43}$

Adams exhibited the rare qualities of a republican statesman in national politics who promoted northern rights. Parker believed that it was essential to look at the North's acquiescence to the South in national debates. He argued that the North allowed the South to promote a proslavery agenda by annexing Texas and initiating a war with Mexico - issues that Democrats believed their victory in the Election of 1844 sanctioned. As an outspoken critic, Adams showed that speaking out against such policies was not treasonous (as his opponents claimed); rather, it was courageous. Parker applauded Adams because he "sought the object of New England far more than the object of the South. ${ }^{\circ 4}$ Parker, an abolitionist who viewed the constitution as an unholy compromise on slavery and who criticized periods of Adams's career during the sermon, nonetheless focused on Adams's defense of human rights in order to show contrast between northern and southern values. "Love of human freedom in its widest sense is the most marked and prominent thing in his character," Parker proclaimed. Adams, unlike political parties that found ways to justify constitutional interpretations for various positions, stood firm in

\footnotetext{
${ }^{43}$ Parker, A Discourse Occasioned by the Death of John Quincy Adams, 13-14.

${ }^{44}$ Ibid., 15.
} 
support of the Declaration of Independence and human liberty. ${ }^{45}$ As northerners appeared complicit in letting southerners push forward with a national agenda favoring territorial expansion, eulogists for Adams indicated a northern commitment to a different vision of democracy, one in which ordinary petitioners and voters with republican virtue, rather than slaveholders and demagogues, ruled.

The Amistad crisis provided another opportunity to promote a form of democracy that cherished human rights. To impede the continued decline of northern culture, more citizens had to take heed of Adams's courageous stands for fundamental rights. Without great men doing so, a democratic republic would ultimately decay. When the Amistad case found its way to the Supreme Court, Adams championed the cause of the Africans held in Connecticut until a decision came deciding if they were enslaved or free. Adams, believing the Africans were robbed of their natural rights, skillfully won them their freedom despite receiving heavy political opposition for doing so. "With no prospect of reward, he came forward to the aid of those unhappy sons of Africa," Stedman Hanks reminded his listeners. He touted that Adams "was ready to do what could constitutionally and prudently be done for emancipation of the bondman. ${ }^{.47}$ Adams was not the "mad and mischievous" man that the southern press accused him of being. ${ }^{48}$ Eulogists argued he was a philanthropic and intelligent man who stood up to proslavery forces in order to preserve the integrity of the law. Livermore remembered that Adams

\footnotetext{
${ }^{45}$ Ibid., 19-20.

${ }^{46}$ Varon, Disunion!, 154-155.

${ }^{47}$ Hanks, A Sermon on the Occasion of the Death of the Hon. John Quincy Adams, 16-17. For similar sentiments on the Amistad, see: Farley, A Discourse on the Life and Character of John Quincy Adams, 9; Joseph Henry Allen, The Statesman and the Man. A Discourse on Occasion of the Death of Hon. John Quincy Adams, Delivered in Washington, Feb 27, 1848 (Washington: J. and G.S. Gideon, 1848), 14-15. ${ }_{48}$ Varon, Disunion!, 111. Varon notes that Adams received extreme criticism from southern presses after his stance in favor of the right to petition. She argues that the press charged Adams with recklessly sowing the seeds of disunion with his "madness."
} 
"stood forth voluntarily as their defender in the Supreme Court of the United States, and gained their cause by dint of the most powerful appeals to truth and right and law."49 To make a rational case for Adams's defense of the Amistad captives served several purposes. Politically, it shaped the debate over human rights and slavery as one in which the law and northern sensibility stimulated a heightened sense of republican duty to do what was best for the common good. In addition, raising awareness in the North would force the Whig Party, which had an antislavery faction within its ranks, to take a stronger stance on the slavery issue when future debates occurred. Rather than view any antislavery stance as toxic and abolitionist-inspired, the memory of the gag rule, the Mexican War, and Amistad that eulogists told laid out a strategy of defending northern rights and human liberty with mainstream appeal. Eulogies, as indicated by the discussions surrounding the "gag rule" and the Amistad, were tied to political controversies of the day. ${ }^{50}$

Eulogists highlighted southerners' attempts to censure Adams as a way to contrast politicians who defended slavery with Adams's advocacy in favor of those who needed protection. Adams's deathbed scene became a way to humanize the problem of slavery as an institution. Slaves needed the protection of republican statesmen such as Adams who looked out for the interest of the dispossessed who were unable to do so for themselves. Eulogies and sermons emphasized that free African Americans came to see Adams in the Capitol and showed their gratitude to him while he lay on his deathbed. "When lying in the cold majesty of death in the Representative Hall," Livermore detailed, "there came, too, the outcast race craving to take a last look at their hero and friend, and no homage to

\footnotetext{
${ }^{49}$ Livermore, The Ancient and Honorable Man, 16.

${ }^{50}$ For more on the political ramifications on the Whigs, see: Varon, Disunion!, 157-158. For similar sentiments, see: Lord, A Eulogy on the Honorable John Quincy Adams, 11.
} 
the mighty dead was more heartfelt than theirs, no tears well up from more grateful hearts. ${ }^{~} 51$ Adams, a man who exhibited traits from a generation fading away, reminded citizens of a statesman who still exemplified republicanism. Adams stood up for the rights of all people under the law, regardless of their sex or color. Eulogists displayed the necessity of great men for the public good, even for those who were not citizens.

Orations displayed the ebb and flow of democracy during the antebellum period, as often they obscured aspects of democracy in order to highlight republican virtue. Despite the antidemocratic tone during many of the orations, they nonetheless were part of a democratic process of public persuasion. By the nineteenth century, technological developments contributed to sermons and eulogies gaining thousands of readers beyond just those in attendance. Telegraph wires spread news quickly, and newspapers published and opined on the nature of the sermons and eulogies for thousands of readers. Walt Whitman, a young newspaperman and aspiring poet, took issue with the way the eulogists remembered Adams. Whitman, who at the time worked for the Daily Crescent in New Orleans, wrote a critical response to eulogists who argued that "the people" did not appreciate Adams's career and virtues. "Some of our Northern contemporaries are stepping entirely beyond the record in their eulogies of Mr. Adams," supposed Whitman. He disapproved of the condescending tone with which eulogists attempted to shape public perception not just of Adams, but also of the merits of democracy. He lamented that "the mass of people" were "brought up as before a tribunal, and treated with a sort of cynical sarcasm, because they did not attach themselves more closely to the ExPresident." Whitman deemed the narrative spun by eulogists to be excessive. He agreed

\footnotetext{
${ }^{51}$ Livermore, The Ancient and Honorable Man, 16. For similar sentiments, see: Farley, A Discourse on the Life and Character of John Quincy Adams, 27; "John Quincy Adams," Christian Recorder, March 4, 1848.
} 
that Adams "was a 'gentleman of the old school,' no doubt," yet he believed it was a positive that the nation was becoming more democratic and moving away from an old school that was "too near monarchy and nobility to be entirely free from their influence." Whitman, a strong advocate for democracy, took part in eulogists' debate about democracy to speak out against the notion that democracy was harmful and that the nation needed to reexamine the course in which politics was heading. ${ }^{52}$

Advocate groups also participated in the democratic process of remembrance with the accessibility of the printing age. The Liberator, an abolitionist newspaper, analyzed the handling of slavery in sermons and eulogies. The paper, aware of Edward Everett's self-censored eulogy, criticized his account of Adams's life. "Mr. Everett was afraid to utter, on the subject, what we have no doubt he felt in his heart," the paper claimed, continuing that "public sentiment is yet on the side of the oppressor, where there is power, and of that sentiment he stands in awe." The flawed nature of politics prevented Everett from speaking freely, according to the Liberator. The paper, which served as a mouthpiece for its founder, William Lloyd Garrison, also believed that Parker's sermon spoke of topics that Everett was afraid to broach. Regarding other orations, the paper stated that "It is no disparagement to any of them to say, that Mr. Parker's discourse throws them all into the shade, on the score of critical analysis of character, and eloquence of thought and expression," particularly because Parker, an influential abolitionist, spoke in detail about the wrongs of slavery. The Liberator, however, believed Parker gave too much credit to Adams as a champion for the slave and the paper

\footnotetext{
${ }^{52}$ Walt Whitman, The People and John Quincy Adams (Berkeley Heights, Oriole Press, 1961), 15-18. Whitman wrote the piece anonymously while working briefly for the Daily Crescent. It was not discovered that he was the author of the piece until the twentieth century. Whitman's editorial is also mentioned in: Parsons, "The 'Splendid Pageant,"” 472-473, and Miller, Arguing About Slavery, 461-462.
} 
opined that Adams never was a leader against slavery despite fighting for the right of petition and other legal positions opposing slavery. ${ }^{53}$

The dissemination of commemorations for John Quincy Adams was unparalleled for the time. The "communications revolution," as Lynn Parsons observes, made it possible for even more Americans to mourn for Adams. ${ }^{54}$ Eulogists used Adams's career and life to warn about the pitfalls of democracy. Adherence to political parties and the democratic election of James K. Polk in 1844, which appeared to lead to corruption involving proslavery politicians, propelled the country into territorial expansion and war for the sake of slavery. Although many of the orations were antidemocratic in tone, they nonetheless were part of a democratic process of public persuasion to make northerners more vigilant in defense of northern rights and the dangers of partisan politics.

While northern eulogists stressed the republican qualities of Adams, southerners voiced similar concerns about virtue, protection of minority rights, and the constitution after the death of John C. Calhoun. The South lost its greatest champion amid national debates concerning the future of western territories gained from the war with Mexico. As one of the foremost advocates for the institution of slavery, Calhoun led southerners in conceptualizing sophisticated ideological, legal, and moral defenses of slavery. His death occurred while Congress debated Henry Clay's compromise proposal in the spring of 1850 , and southerners understood the ways it marked a transitional moment in southern advocacy for slavery. In his home state of South Carolina, eulogists framed their commemorations of Calhoun within the context of broader national political concerns about the future of government and slavery. Eulogists used Calhoun's career to shape

\footnotetext{
53 “John Quincy Adams" Liberator, June 16, 1848.

${ }^{54}$ Parsons, "The 'Splendid Pageant,"” 465-466.
} 
public understanding of the political events that jeopardized the nation, just as orators did after Adams's death. While there were both unionists and secessionists who delivered orations, eulogies and sermons openly discussed the possibility of disunion and placed slavery, republicanism, and the constitution at the center of the debate. The eulogists established reasoning behind disunion, which propelled the rhetoric throughout the South for the next decade, until South Carolina began the wave of secession in 1860 .

Eulogists warned their listeners of the dangers that faced the South. The rise of democracy and party politics ushered in the possibility of social upheaval, which alarmed eulogists who used their prominent social standing to impress those concerns onto their listeners. While eulogies delivered in Congress for Calhoun, most notably by Daniel Webster and Henry Clay, received some admiration by southerners for praising Calhoun's statesmanship and devotion to the Union, they nonetheless avoided Calhoun's controversial beliefs and actions regarding slavery. ${ }^{55}$ In South Carolina, however, those controversial issues — his warnings about the majority trampling the rights of the minority, the attacks on the tariff and Force Bill, and the legal and moral arguments supporting slavery—gave eulogists rhetorical ammunition to attempt a process of cultural persuasion. Opinion on those issues differed drastically from those who eulogized Adams, yet they nonetheless echoed the same concerns about majorities silencing the rights of minority interests. As South Carolina debated secession due to the prospect of

\footnotetext{
${ }^{55}$ Webster and Clay struggled with the content of their eulogies for Calhoun. Particularly Webster attempted to give praise to Calhoun while simultaneously distancing himself from Calhoun's views. He mostly discussed Calhoun's personal qualities, yet in order to avoid criticism from northerners he withdrew his name from one of six chosen to escort Calhoun's body to South Carolina, believing that it would be carrying his "southern courtesy" too far. It is worth noting that Calhoun's political beliefs did cause some contentiousness in the senate after his death. Thomas Hart Benton declined to speak. "He is not dead, sir he is not dead. There may be no vitality in his body, but there is in his doctrines," objected Benton. Merrill D. Peterson, The Great Triumvirate: Webster, Clay, and Calhoun, (New York: Oxford University Press, 1987), 467.
} 
legislation hindering slavery, eulogists criticized the premises of democracy and promoted a proslavery version of republicanism. ${ }^{56}$

Eulogists spoke of a southern society under attack by forces trying to subvert the constitution. They argued that Calhoun, despite claims to the contrary from northerners, was one of the few who opposed attempts to undermine the true intentions of the Revolutionary era and was a guardian of constitutional rights. The Presbyterian minister and disunionist, John C. Coit, a self-professed disciple of Calhoun, praised Calhoun for vigilantly fighting for the interests of the South. ${ }^{57}$ Coit commended Calhoun's independence in Congress as always being "too high toned in honor, truth, and virtue" to be a leader of a political party. ${ }^{58} \mathrm{He}$ maintained that Calhoun stood in contrast to the demagoguery and dangers that democratic culture posed to republics. "That a majority have the right to govern, became the popular cry, east and west, and of a national party everywhere," Coit described as he then warned that majority rule threatened southern interests and the true intention of the constitution being a compact of states. The Founders, he extolled to his audience, intended to defend the rights of the minority from the encroachments of the majority. The rise of democracy and national parties only served to strengthen the control of the federal government and to oppress the rights of individual states. ${ }^{59}$

\footnotetext{
${ }^{56}$ For information on Calhoun's ideology on republicanism, slavery, and the economy in comparison to how it is depicted in orations, see: Lacy K. Ford, Jr. "Republican Ideology in a Slave Society: The Political Economy of John C. Calhoun" The Journal of Southern History 54, (August 1988).

${ }^{57}$ Richard J. Carwardine, Evangelicals and Politics in Antebellum America (Knoxville: The University of Tennessee Press, 1997), 186.

${ }^{58}$ J.C. Coit, "Eulogy on the Life, Character and Public Services of a Hon. John C. Calhoun, Pronounced by Appointment, before the Citizens of Cheraw and its Vicinity, on Wednesday, April 24, 1850" in The Carolina Tribute to Calhoun, 152.

${ }^{59}$ Ibid., 160.
} 
While the two-party system materialized, albeit with resistance nationwide, it received the most opposition in South Carolina, where the planter class sought to keep national parties out in order to further control state politics. Coit exhorted that the constitution defended the rights of states, and that the parties and masses threatened that protection. "The rights of the States can never be defended by federal or national parties," he argued, continuing to note that "These rights must be maintained by the States themselves, or their own people, where rights, honors, or liberties may be invaded by federal usurpation." To Coit, South Carolinians needed to defend the true intention of the constitution and resist the evolving democratic culture. If those changes continued to threaten South Carolina, then its citizens had a republican duty to defend the state by sword if necessary. ${ }^{60}$ Reverend James Mills echoed Coit's concerns by arguing that resisting democracy was the surest way to defend true equality. "If, then, a particular class who have not reached the intellectual, moral and political development which implies the fitness or right of self-government, be nevertheless admitted to full and equal citizenship in the commonwealth," maintained Miles, "it is evident that true political equality will be violated, and the perfect idea of a just, self-governing Commonwealth will be infringed." ${ }^{, 61}$ Eulogists resurrected similar concerns about self-government debated during the Revolutionary era. Through Calhoun's supposed statesmanship and rejection of the cultural changes unleashed by Jacksonian democracy, eulogists condemned the demagoguery that endangered the social and political structures intended by the Revolution.

\footnotetext{
${ }^{60}$ Ibid., 162-163.

${ }^{61}$ Miles, "The Discourse on the occasion of the Funeral of the Hon. John C. Calhoun," in The Carolina Tribute to Calhoun, 197.
} 
Democratic culture caused anxiety over whether or not men elected by "the people" would protect southern interests. More than just the concern of slaveholders, the democratic movement raised fears about untrustworthy politicians and an upheaval of the social structure in the South. Presbyterian theologian and influential South Carolinian James Henley Thornwell often spoke out against the ascension of egalitarianism in his sermons and writings. Thornwell, who detested the new power that the masses held, promoted a return toward traditional republicanism. ${ }^{62}$ As he did in other sermons, his oration on behalf of Calhoun cautioned about the dangers democracy posed amid the sectional tensions in 1850. According to Thornwell, the current crisis demanded statesmen instead of "jobbers and politicians." He lamented that "dwarfish politicians" could not see beyond narrow circles of sections, parties, or cliques in order to make manly and honorable decisions for the public good. "A statesman is a sublime character—a jobbing politician too little for contempt," he warned. ${ }^{63}$ Thornwell, as with other orators, believed Calhoun embodied the characteristics of a statesman, someone who was not swayed by public passions or narrow party interests. The public comments about Calhoun's attributes go further than simply praising their dead leader. The sermons and eulogies gave clear warnings to southerners about the dangers that democracy posed to social hierarchy. The type of politicians that democracy produced ran contrary to the values of republicanism, old school traditional theology, and southern culture.

\footnotetext{
${ }^{62}$ Mark J. Larson, "A Champion of the Original American Republic: The Political Thought of James Thornwell," The Journal of Presbyterian History 82, (winter 2004): 261.

${ }^{63}$ James H. Thornwell, "Thoughts Suited for the Present Crisis: A Sermon, on Occasion of the Death of Hon. John C. Calhoun, Preached in the Chapel of the South Carolina College, April 21, 1850," in The Carolina Tribute to Calhoun, 118-119. For more on Thornwell and his varying ideas on the issue of slavery and threats to the South's social system, see: William W. Freehling, "James Henley Thornwell's Mysterious Antislavery Moment" The Journal of Southern History 57, (August 1991): 383-406); and Charles C. Bishop, "The Pro-Slavery Argument Reconsidered: James Henley Thornwell, Millennial Abolitionist" The South Carolina Historical Magazine 73, (January 1972): 18-26.
} 
Calhoun's eulogists found antidemocratic thought useful as a rhetorical tool to both safeguard as well as destroy the Union. They argued that Calhoun was the type of independent and virtuous leader needed to defend southern culture, yet they worried that a new generation of virtuous men did not exist to take his place. Echoing the words of Thornwell, Benjamin M. Palmer, who was also a Presbyterian theologian who received a northern education and was a well-known member of society, spoke of these concerns during his sermon on behalf of Calhoun. In speaking of his apprehension over the country's political crisis, Palmer believed Calhoun offered a model of what kind of man could save the nation from ruin. ${ }^{64}$ Calhoun was not the reckless disunionist as some claimed in the North, Palmer argued, but rather was one of the few who offered the blueprint for preserving the Union and should serve as a lesson to those in Congress. Palmer desired the chance to speak in Congress about Calhoun, and told his listeners he would "dissuade them from that intense devotion to party which shuts the country out of view, and forestalls that conciliation and mutual concession, without which they can be neither statesmen nor patriots. ${ }^{, 65}$ The antiparty and antidemocratic tone of eulogies for Calhoun promoted the notion that several factors threatened society, and Calhoun's statesmanship provided an example of the type of figure that South Carolinians needed to emulate and vote for.

Eulogists believed democracy and party politics threatened slavery. As one of the most important proslavery clergyman in the South, Thornwell often spoke of the religious and social virtue of slavery in his sermons. He believed that democracy threatened slavery and thus the South's social hierarchy. To Thornwell, slavery's disruption would

\footnotetext{
${ }^{64}$ B.M. Palmer, "A Discourse on the Occasion of the Death of Hon. John C. Calhoun, Delivered April 21, 1850, in the Presbyterian Church of Columbia, South Carolina," in The Carolina Tribute to Calhoun, 244. ${ }^{65}$ Ibid., 245.
} 
mirror the harms that democracy wrought, and that to rise suddenly from despotism to freedom for slaves would bring "licentiousness, anarchy, and crime." ${ }^{96}$ Reverend Coit similarly defended the righteousness of the institution of slavery. "Under the gospel, slavery was treated, by our Saviour [sic], as an existing and lawful institution, and by his apostles he enforces the relative duties of masters and slaves," he reminded his listeners during his sermon. Coit spent a significant portion of his sermon justifying slavery. In addition to giving religious justification, he also defended the positive influences it had on the slaves. He reinforced the paternalistic notion that while they lacked political rights, slaves, like women and children, enjoyed the common protection and securities provided to them by republican masters. The focus on the paternalistic aspects of slavery in orations for Calhoun mirrored those delivered after Andrew Jackson's death. ${ }^{67}$

The defense of slavery in these orations is unsurprising considering the institution's importance to their society, yet it also begs the question, "why defend an institution that already had strong support?" The eulogists did not merely attempt to prove slavery was good; rather, they knit slavery into the fabric of the South's nationalist vision. With Calhoun dying in the midst of sectional crisis in the spring of 1850 , eulogists used his legacy to promote a nationalist vision of slavery and define the parameters of debate over slavery's position in politics and society. Eulogists vied for control over Calhoun's memory when debating the merits of disunion. Coit connected slavery and democracy. "As all our present troubles spring from the slavery and majority questions, and as the moral character of slavery is at the root of that matter, it may be pertinent to consider for a moment that question," he stated, and questioned, "what is the real value

\footnotetext{
${ }^{66}$ Thornwell, "Thoughts Suited for the Present Crisis," in The Carolina Tribute to Calhoun, 123.

${ }^{67}$ Coit, "Eulogy on the Life, Character and Public Services of a Hon. John C. Calhoun," in The Carolina Tribute to Calhoun, 179.
} 
and weight, politically and morally, of any numerical majority in our federal legislative government." For Coit, disunion seemed a likely course of action and felt that the respective states were the only real protection for "the people." Slavery made the prospects of a democratic society dangerous. ${ }^{68}$

Eulogists attempted to show that attacks on slavery were part of a broader danger posed by the federal government. Frederick Porcher, Professor of History at the College of Charleston and a proslavery intellectual, touted Calhoun's foresight to see disunion as a possibility if the South's minority rights became threatened. According to Porcher, Calhoun was one of the true unionists who always fought to preserve the Union. Yet, that Union increasingly looked different from the world that he fought to preserve. "For majorities in all popular government are apt to become despotic, and when the majority and the minority are to be found in different sections of the country," Porcher declared, "it is unreasonable to expect that the minority will quietly submit to be reduced to a state of colonial vassalage. ${ }^{\prime 69}$ Attacks on the democratization of government and the defense of slavery went hand-in-hand when defining the interests of the South. Calhoun's career defending minority rights served as a clear example of the necessity of a unified South. "That voice will cry aloud with irresistible eloquence, that without equality of rights the Union cannot continue to exist," Porcher stressed the importance of slaveholders' rights. ${ }^{70}$ Throughout his sermon, he warned about the future the South faced from a northern majority and from party politics. He believed that disunion was justifiable and in tune with Calhoun's beliefs in order to preserve racial hierarchy, elite rule, and the rights

\footnotetext{
${ }^{68}$ Ibid., 175.

${ }^{69}$ Frederick A. Porcher, "Eulogy on the Late Hon. John C. Calhoun, Delivered Before the Cliosophic and Chrestomathic Societies, of the College of Charleston, on Thursday, July $6^{\text {th, }} 1850$," in The Carolina Tribute to Calhoun, 276-277.

${ }^{70}$ Ibid., 280.
} 
of minority interests. ${ }^{71}$

Defining the constitution on the South's terms lay at the heart of eulogies of Calhoun. He fought for the Revolution's legacy when he opposed the tariff and Force Bill during Andrew Jackson's presidency, and continued to do so through his defense of minority rights. Highlighting these political events, which many northerners argued were unpatriotic and disunionist, provided a moment for eulogists to challenge that perception and argue that Calhoun always fought to preserve the constitution. Calhoun's work, however, was unfinished and orators maintained it was the responsibility of southern citizens to continue his cause. "Majorities do not rely on constitutions. Their reliance is on numbers and the strong arm," contended James Henry Hammond during his oration in honor of Calhoun. Hammond, a secessionist-leaning South Carolina politician, capitalized on the contentious political climate and focused on Calhoun's defense of minority interests and the constitution for much of his eulogy. "It has now become manifest, for the first time since the Constitution had gone into operation, that it might be so contrived as to oppress and ruin one section for the benefit of another," he warned to his Charleston audience. Hammond aggressively detailed the dangers of a democratic majority to the constitution and to the South. He expressed a grim future for southerners unless significant action was taken to secure rights against democratic despotism. Calhoun's career, Hammond explained, was one of justice and defense of the constitution. Calhoun's idea of Nullification was an admirable and legal attempt to avoid

\footnotetext{
${ }^{71}$ For more on the political, social, and racial ideology of Frederick Porcher, both before and in particular after the Civil War, see: Charles J. Holden, In the Great Maelstrom: Conservatives in Post-Civil War South Carolina, (Columbia: University of South Carolina Press, 2002).
} 
secession, not to initiate it, Hammond maintained. ${ }^{72}$ While northerners remembered Adams for his defense of the right of petition, Calhoun's eulogists praised his defense of the gag rule in order to halt a violent and unconstitutional crusade against the South. Hammond argued that the increasing majority in the North continued to subvert the constitution, as was the case with their desire to force petitions and use majorities to subjugate the South. ${ }^{73}$

Hammond's eulogy of Calhoun took place just days before the senatorial election in which he ran against the fire-eater R. Barnwell Rhett. ${ }^{74}$ Both Hammond and Rhett viewed the prospect of disunion favorably, but there were divisions among secessionists about whether or not secession could be viable for South Carolina if other southern states were not willing to join. ${ }^{75}$ Hammond viewed Rhett's stance on immediate action to be reckless. Although Hammond had a long and at times ambivalent relationship with Calhoun, he hoped that South Carolinians would see him as the true heir apparent, not Rhett. Hammond displayed his political maturity during his oration, and he attached his

\footnotetext{
${ }^{72}$ J.H. Hammond, "An Oration on the Life, Character, and Services of John Caldwell Calhoun, Delivered on the $21^{\text {st }}$ November, 1850 , Charleston, S.C., at the Request of the City Council," in The Carolina Tribute to Calhoun, 295. Hammond discussed the gag rule and petitioning issues on pages 313-314.

${ }^{73}$ For more on the topic of southern nationalism, see: Robert E. Bonner, Mastering America: Southern Slaveholders and the Crisis of American Nationhood, (New York: Cambridge University Press, 2009). Bonner argues that southerners attempted to nationalize slavery through proslavery republicanism, evangelism, memory, and domesticity.

${ }^{74}$ Hammond lost the election to Rhett, indicating the strong support that Rhett's immediate secessionist message had with the legislature.

${ }^{75}$ Secessionists were divided into separatists and cooperationist factions. Separatists pushed for secession regardless of whether other southern states were willing to follow suit. Cooperationists thought it necessary for other southern states to join and had some unionists within their ranks. For more on this issue see: Manisha Sinha, The Counter-Revolution of Slavery: Politics and Ideology in Antebellum South Carolina (Chapel Hill: University of North Carolina Press, 2000), 113-118; and William W. Freehling, The Road to Disunion: Secessionists at Bay 1776-1854 (New York: Oxford University Press, 1990), 528-533.
} 
own career and beliefs to those that Calhoun had exhibited. In addition, his eulogy reflected his desire for a united South when considering the prospect of secession. ${ }^{76}$

Hammond contended that a unified South was the only way to defend the constitution. Not surprisingly, he charged abolitionists with attempting to gain political power to enlarge their domain at slaveholders' expense and to poison the minds of nonslaveholders throughout the South. He claimed that abolitionists and the two national political parties conjured up disunion in order to denounce slavery and divide the South. For decades, the South had Calhoun, who proved incorruptible and unwavering in the face of public opinion. Hammond argued that Calhoun tried desperately to save the Union until his death. Yet, his long struggle for justice and the constitution remained unfinished, and Hammond used his eulogy to promote his policy of cooperative state secession due to the increasing power the North could obtain because of a democratic majority. The debate over disunion came down to whether secessionists could convince southerners of its necessity. Hammond contended that Calhoun "devoted all his talents and all his energy to arrest the march of usurpation and corruption, and to preserve the liberties and institutions inherited from our fathers," once he realized that central despotism remained a threat. ${ }^{77}$ Calhoun responded by becoming an expert on the constitution and lifted himself above all parties to become a philosophical statesman, according to Hammond. He believed that now was time for South Carolinians to follow through on Calhoun's vision for a united South. Disunion served as a possible remedy to the threats posed to southern states.

\footnotetext{
${ }^{76}$ Drew Gilpin Faust, James Henry Hammond and the Old South: A Design for Mastery (Baton Rouge, Louisiana State University Press, 1982), 300-303.

${ }^{77}$ Hammond, "An Oration on the Life, Character, and Services of John Caldwell Calhoun," in The Carolina Tribute to Calhoun, 324.
} 
The Compromise of 1850, recently passed, served as evidence that it was time for aggressive action by the southern states. Calhoun played the role of the martyr in Hammond's tragic tale. He argued that Calhoun tried valiantly to fix the problems of the constitution and government, but that the compromise bills ultimately showed that his efforts were in vain. "California has been admitted and the equilibrium of the Government has been destroyed forever," Hammond exclaimed to his audience. "The edict has gone forth that no new slaveholding State shall ever enter the Union: and the South, deprived at last, and finally of her equality in the Senate...is now condemned to a minority that can know no change, in every department of the Federal Government," he lamented. Hammond surmised that the slaveholding states had become provinces of a "great empire, ruled by a permanent sectional majority, unrelentingly hostile to them, and daring as it is despotic." ${ }^{, 78}$ Hammond utilized Calhoun's defense of slavery to convey that the North and South were two distinct social systems that could not be protected by one government. Hammond laid out the reasoning for why slave states needed to unite against the North before it reached a point of being too late. While men such as Hammond who actively spoke of disunion are often dismissed as radical and irrational, they articulated valid concerns about the future of slavery and the need to take drastic measures before the opportunity to do so was lost. As South Carolinians debated secession in 1850, men such as Hammond prophesized grave consequences due to the rise of democracy and the hostile advocacy groups supposedly trying to subvert the constitution and destroy the social fabric of the South.

Robert Barnwell Rhett was keenly aware of the urgency to win the battle for public opinion on secession before the sectional passions from the Compromise of 1850

${ }^{78}$ Ibid., 318. 
cooled. Rhett, appointed the official orator before the South Carolina assembly, portrayed Calhoun as a prophet of secession. ${ }^{79}$ In a similar vein as Hammond, Rhett used his eulogy for Calhoun to conjure up emotions of the Revolutionary era and to show his listeners why secession was a patriotic and necessary prospect. Yet, both the separatist and cooperationist factions (Rhett led the former) vied for Calhoun's legacy. Rhett focused on three aspects of Calhoun's career — the War of 1812, the tariff, and slavery—in order to make his case for disunion. He argued Carolina had a history of fighting for liberty, and discussed the War of 1812, or the "Carolina War," as one for independence. Calhoun championed the need to go to war because fundamental struggles for rights and liberty were at stake against oppression and power asserted Rhett. ${ }^{80}$ The tariff situation offered another example of South Carolina willing to fight for its basic liberties in the belief that the constitution was a compact of states and that secession was a legal remedy for an overreaching federal government. Rhett praised Calhoun for being the architect of nullification and the ideology of secession, both of which were on display during the tariff and Force Bill tensions. He credited Calhoun for not being a part of any national political party, but applauded him for being a Nullifier. While Whigs and Democrats made unconstitutional compromises and pandered to the masses for votes, Nullifiers believed in the threat of majorities to the constitution and an unwavering right to secede, stressed Rhett. He questioned the notion that the Union must be preserved. Rhett hailed Calhoun's efforts to do so, but he also acknowledged the danger posed to states if the Union was preserved by force. At the heart of the issue lay the belief that the constitution

\footnotetext{
${ }^{79}$ Merrill Peterson notes how Rhett argued Calhoun was a "prophet of secession" and that in his eulogy, Rhett suggested that if Calhoun had lived just one more hour to speak in the senate he would have advocated for disunion. Peterson, The Great Triumvirate, 476.

80 "Oration of the Hon. R. Barnwell Rhett, Before the Legislature of South Carolina, November 28, 1850," in The Carolina Tribute to Calhoun, 334, 338.
} 
consisted of a compact made by states, not by "the people." He believed Calhoun deserved praise for defending the true meaning of the constitution and the right of secession.

Rhett depicted Calhoun as a visionary who connected constitutional rights with a proslavery message. Calhoun defended slavery on legal grounds and developed a sophisticated argument for the institution as a positive good. Calhoun's refusal to consider slavery evil changed the debate and now southerners launched a vigorous defense of slavery. Rhett believed that it was time for slaveholding states to take any necessary measure to defend slavery from a growing antislavery movement. Rhett, like other secessionists, saw the impending crisis as inevitable. He repeated Calhoun's own words in his eulogy, reminding his listeners that Calhoun once declared, "Abolition and the Union cannot co-exist. As the friend of the Union, I openly proclaim it; and the sooner it is known the better." Rhett understood the merits of using patriotism to persuade the public to fight for slavery's protection. Promoting southern nationalism and a proslavery interpretation of the constitution provided a credible argument to sway public perception on the issue of disunion. ${ }^{81}$

Calhoun's defense of slavery and the restriction of petitions gave further proof that the time had come to secede. Rhett believed that Calhoun's failed struggle to keep petitions out of Congress was enough reason to leave the Union. The exclusion of petitions in Congress relating to slavery was the only way to safeguard the institution from the growing influence of the abolitionist movement in the North. He thought that the spirit of abolitionism "should have been met by a determination equally strong on the part of the South, to dissolve the Union the instant of its abrogation." He surmised that

81 "Oration of the Hon. R. Barnwell Rhett," in The Carolina Tribute to Calhoun, 361. 
had just two states withdrawn their representatives that they would have ultimately procured new guarantees for slavery's protection. ${ }^{82}$ The window to take effective action, however, was closing. The legacy of the Revolution, the constitution, and the survival of southern society depended on swift action by the South. Rhett crafted a eulogy that praised Calhoun for his proslavery republicanism and attempted to convince "the people" that the fanaticism in the North was only going to intensify due to the egalitarian mindset of that region's political culture, and that it would ultimately bring ruin for the South's cherished institutions and Revolutionary legacy. ${ }^{83}$

Eulogists differed on whether disunion was something that would be in the best interest of the South. There was consensus over the danger that a democratic government posed for its social systems but disagreement as to whether secession offered the surest protection. Although James Thornwell was one of the leading mouthpieces for the planter class, he was also a unionist who foresaw grave ramifications if South Carolina seceded. He recognized that the nation's existence was at stake during the debates over Clay's compromise measures in 1850. Dissolution of the Union, which was "consecrated by patriot blood," would be a catastrophe, believed Thornwell. Even more important than the destruction of the nation that the Revolution built, he prophesized an ominous future if the South chose to go that route. "To suppose that this confederacy can be dissolved without cruel, bloody, ferocious war, terminating in a hatred more intense than any which ever yet disgraced annals of any people — is to set at defiance all the lessons of history," he warned his audience during his sermon on Calhoun. He continued to caution that,

\footnotetext{
${ }^{82}$ Ibid., 363.

${ }^{83}$ For similar sentiments on Calhoun's position on the issue of petitions, see: Robert Henry, "Eulogy on the Late Hon. John Caldwell Calhoun, delivered at Columbia, South Carolina, on Thursday, May 16, 1850," in The Carolina Tribute to Calhoun, 235.
} 
"The consequences, civil, political, religious, which would result, not simply to us, but to mankind, from the destruction of this glorious confederacy, cannot be contemplated without horror," and that the present crisis was the most important the nation had faced. ${ }^{84}$ While some eulogists contended that northern and southern societies were too different for the Union's continuation, others believed that their similarities made peaceful separation impossible. Benjamin Palmer still thought disunion was an illconceived plan in 1850. "We amuse ourselves with the hope of a quiet and peaceful secession," he declared during his sermon for Calhoun. "What people sprung from a common ancestry, of our blood, having the same language, the same laws, and the same religion, enjoying a common inheritance of liberty and glory, ever separated without bloodshed into two rival nations?" he asked his listeners. Disunion would only lead to violence and continued agitation, Palmer believed. Eulogists against disunion in $1850 \mathrm{did}$ not discount the ability to do so or that someday such action would be necessary. Opinions on secession did not break along class lines as debate continued to intensify in South Carolina in 1850. While some fiery orations delivered in honor of Calhoun spoke of the necessity and positives of disunion, other eulogists looked to Calhoun's career to show why it was not the time to secede. ${ }^{85}$

Examining the orations for Calhoun sheds light on the mindset of South Carolinians who directed the South regarding disunion. Historians continue to debate if secession in South Carolina was a product of a cultural hegemony of the planter class over yeomen farmers, or if ultimately the yeoman population determined secession was necessary because of their strong beliefs in "country republicanism." As southerners

\footnotetext{
${ }^{84}$ Thornwell, "Thoughts Suited for the Present Crisis," in The Carolina Tribute to Calhoun, 108-110.

${ }^{85}$ Palmer, "A Discourse on the Occasion of the Death of Hon. John C. Calhoun," in The Carolina Tribute to Calhoun, 248-249.
} 
contemplated disunion in 1850, eulogists used Calhoun's legacy to instill amongst "the people" a fervent set of beliefs in the righteousness of slavery, the federal constitution, and liberty. In addition, eulogists attempted to incorporate antidemocratic ideals that showed the danger that majoritarian influence had on the South. There was not a consensus among eulogists on secession in 1850 , yet they hoped to implant a mindset within South Carolinians that linked antidemocratic language with the deeply rooted proslavery republicanism inherited from the Revolution. The protection of political institutions that defended slavery was paramount to southern elites, regardless of opinion on disunion in 1850. Eulogists understood that preaching an antidemocratic message was imperative to promoting proslavery republicanism and southern rights. ${ }^{86}$

John Quincy Adams and John C. Calhoun both passed away during a tumultuous time for the nation. The remembrances of the two men highlight the uneasiness and divided nature of the period in which the country became more egalitarian and grew due to territorial expansion and war. Adams and Calhoun similarly represented the republican virtue of an era that had seemed to fade away, causing eulogists to look back nostalgically at their careers. Both the North and South looked to their respective

\footnotetext{
${ }^{86}$ Two of the leading works on secession in South Carolina that have shaped the interpretation of Calhoun's eulogies are: Jr. Lacy K. Ford, Jr. Origins of Southern Radicalism: The South Carolina Upcountry, 1800-1860 (New York: Oxford University Press, 1988) and Manisha Sinha, The CounterRevolution of Slavery: Politics and Ideology in Antebellum South Carolina (Chapel Hill: University of North Carolina Press, 2000). Ford and Sinha disagree on the cause of secession in South Carolina. Ford contends that secession was possible because of the dominance of the "country-republican" ideal that placed personal independence and liberty as central to yeomen farmers. While he downplays the role of planters finally bringing secession, Sinha disagrees and argues the planter class exerted their influence to counter threats of democracy and that secession was the "last foray" of the planter class. Both arguments have merit. This dissertation chapter contends that eulogists combined antidemocratic rhetoric with advocacy of proslavery republicanism in order to mold public opinion on the issue. Ford argues that secession did not happen in 1850 because the planters could not sway yeomen farmers to believe that their liberty was threatened. Yet, eulogies for Calhoun indicate that the elite class in South Carolina still was divided on secession in 1850, and prominent members gave grave warnings about possible disunion. While republican ideology was significant to yeomen farmers, eulogists effectively demonstrated how democracy fit into the dangers that could threaten their liberty and republican ideals.
} 
statesmen for guidance during uncertain times. Eulogists used the careers of Adams and Calhoun to resist the political tide moving away from republicanism and to harden sectional ideology concerning legal rights and the institution of slavery. Northern eulogists used Adams's legacy to raise concerns about aspects of democratic political culture and restore traditional republicanism along with a call to defend northern rights against an increasingly influential Slave Power. South Carolinians similarly looked back at Calhoun's long career to rally southerners against the dangers of a democratic majority and to argue that defending slavery was a vital component to one's patriotism. Eulogists focused on the defense of minority rights by both Adams and Calhoun through their political independence from a demagogic orientation of political parties. The eulogies of the two men illuminate the continued fissures underneath a society that appeared to welcome the burgeoning democracy and party politics during the antebellum era. There was a conciliatory tone for Adams and Calhoun in Congress in the wake of sectional tensions over war, slavery, and territorial expansion, but orations in their respective regions did not follow suit. Instead, they displayed that these issues caused some to promote republican virtue and sectional solidarity for protection from an uncertain future. Eulogists debated democracy in their orations after the deaths of Adams and Calhoun. The eulogists' role in democratic political culture was full of contradiction as they often communicated antidemocratic beliefs through the means of democratic culture. Their definitions of democracy oscillated depending on their political objectives. The eulogizing class remained apprehensive about the intensely partisan political culture into the 1850s. After the deaths of Daniel Webster, Henry Clay, and John C. Calhoun, eulogists crafted memories of the "Great Triumvirate" that portrayed them as nonpartisan 
defenders of American republicanism. The memories made by eulogists had significant influence on how contemporaries viewed the Election of 1852 and the ability of new politicians to live up to the standards set by the memories of the Great Triumvirate. 


\section{Chapter 4:}

\section{"The Last Has Been Gathered to the Tomb of His Fathers": The Memory of the Great Triumvirate and its Influence on 1850s Political Culture}

When they heard church bells tolling on the Sabbath morning of October 24, 1852, the citizens of Marshfield, Massachusetts knew it was time to mourn their town's favorite son. The news of Daniel Webster's death spread quickly to towns across the United States, where countless Americans grieved the loss and celebrated the life of a man whom they considered the greatest statesman since the Founding generation. Indeed, Webster's death marked the passage of the Great Triumvirate from the political sceneJohn C. Calhoun had died in 1850 and Henry Clay died just months before Webster. ${ }^{1}$ "Calhoun, Clay and Webster are gone; the mighty pillars of the State are swept away" asserted the New York Express. ${ }^{2}$ Others lamented, "The departure of Mr. Webster closes the earthly career of that trio of statesmen who have conferred immortal honor on their country—Calhoun, Clay, Webster." Since their arrival onto the political scene in 1813, the lives and legacies of the three men remained linked. With Webster hailing from the North, Clay the West, and Calhoun the South, each gained a devoted following within

\footnotetext{
${ }^{1}$ Merrill Peterson, joint biographer of Webster, Clay, and Calhoun, cites 1832 for the beginning of the Great Triumvirate name for the three men. "In 1832, when they came together in the Senate for the first time and coalesced in opposition to the president, Andrew Jackson, the idea of 'The Great Triumvirate' was born." Merrill D. Peterson, The Great Triumvirate: Webster, Clay, and Calhoun (New York: Oxford University Press, 1987), 5. There were at times other names to connect Webster, Clay, and Calhoun. C.M. Butler, chaplain of the Senate during the deaths of the three, began his sermon for Webster by noting, "The Last of 'the three mighties' is no more." C.M. Butler, "A Wise Man is Strong." A Sermon on the Death of Daniel Webster, Delivered in Trinity Church, Washington, D.C., November 7, 1852 (Washington: W.M. Morrison \& Co., 1852), 3.

${ }^{2}$ Robert V. Remini, Daniel Webster: The Man and His Time (New York: W.W. Norton and Company, 1997). pp. 761-762; for more on the other members of the Great Triumvirate, see: Irving H. Bartlett, John C. Calhoun: A Biography (New York: W.W. Norton and Company, 1993); Robert V. Remini, Henry Clay: Statesman for the Union (New York: W.W. Norton and Company, 1991).

3 "Death of Mr. Webster" Gleason's Pictorial Drawing - Room Companion, November 6, 1852.
} 
their regions while also attaining national appeal as republican statesmen due in large part to their association with one another.

Although the words of Webster, Clay, and Calhoun no longer reverberated in the halls of Congress, the memories of these men were just beginning to coalesce in the contested arena of antebellum democracy. Eulogies solidified the cultural notion that these three constituted a "great triumvirate." Through eulogies, sermons, speeches, and newspapers, the political process of mourning cleansed Webster, Clay, and Calhoun of their faults and created a perception that all three rose above partisan strife and sacrificed their own personal gain for the good of the Union. Public mourning after their deaths revived political memories over the meaning of divisive issues such as the Nullification Crisis and the Compromise of 1850, and constructed an image of the Great Triumvirate to fulfill a longing for the country's return to its republican roots. Eulogists spoke nostalgically about the loss of the Great Triumvirate to cope with and warn of the undesired aspects of democratic political culture.

Americans keenly felt the loss of these men on the eve of 1852's presidential election. As supporters of Franklin Pierce and Winfield Scott grappled over questions regarding the masculinity and personal character of the candidates, citizens adopted the strategies of the eulogizing class, using cartoons, public commemorations, and newspapers to display uneasiness as to whether new politicians could replace their fallen heroes. Lacking trusted stalwarts such as Calhoun, Clay, and Webster for guidance and assurance in political matters, many citizens continued to deplore the fraud and deception of the democratic political culture. Citizens mourning the country's loss after the passing of each member of the Great Triumvirate furthered a belief that the Triumvirate, as heirs 
of the Founding generation, represented a golden age of republican leaders. While exalting the achievements of the Great Triumvirate, clergymen, writers, politicians, and lawyers obscured the contentiousness of past political debates in order to speak of the potential for national unity and an era of inspiring republican leadership. Even though Webster, Clay, and Calhoun often debated and disagreed with one another, a romanticized notion that they did so for the sake of the country increased after their deaths, which led to a greater acceptance of their past policies and continued anxieties about whether a future generation of politicians would fill the void when new issues arose. Eulogists denounced the demagogic condition of democratic culture even as they emulated those methods in order construct an unrealistic image of the Great Triumvirate.

Eulogists reminded Americans that they had experienced such a national loss before. Reverend Henry Bellows lamented that Webster's death concluded the procession of "giant statesmen and patriots," that began with the passing of George Washington. But Bellows tried to bolster Americans' courage. "What may not be hoped of a land," he intoned, "which in three years could lose such a triumvirate of patriots and statesmen as Calhoun, and Clay, and Webster! - which buried in one day Jefferson and Adams!"4 Bellows's words reflect the vital emotions of eulogists who simultaneously lionized these leaders' reputations and achievements of the previous decades, and obscured their partisan squabbling throughout political debates in the first half of the nineteenth century. Through personal sacrifice and devotion to the Union, men such as Webster, Clay, and Calhoun, along with the Founding Fathers, built the nation in which current citizens benefitted. With the "greatest of the Helmsmen" gone, Bellows called upon citizens on

\footnotetext{
4 “A Discourse on the Death of Daniel Webster," New York Daily Times, November 1, 1852. New York Daily Times hereafter cited as NYDT.
} 
the eve of the 1852 presidential election to put away selfishness and do their sacred duty to vote conscientiously. Only then, Bellows asserted, could they prove themselves worthy to avoid the "perils and evils which must otherwise follow our bereavement as a nation, or fit to perform the new duties which fall upon a people, for the first time thrown upon their own intelligence the impersonation of our national dignity." ${ }^{5}$ For Bellows, it was now time for citizens to prove themselves capable of sustaining a democratic republic by looking beyond partisan rancor and elevating a new generation of "great men." Whether they had the ability to do so remained uncertain.

Multitudes of political studies have documented the political debates and party positions surrounding national disputes such as the Nullification Crisis and Compromise of $1850 .{ }^{6}$ Yet, much of the scholarship lacks an adequate engagement with the remembrance of these contentious events and how those memories influenced the public's perception of the future. The act of reminiscing about the debates and speeches by Webster, Clay, and Calhoun solidified their image as statesmen who had the character, intellect, and virtue required for republican men. The memory of the Great Triumvirate had a significant effect on a public that looked backward toward republican ideology and revolutionary heritage for assurance and guidance for the future. The legacies of Webster, Clay, and Calhoun continued to permeate and influence how citizens conceptualized volatile issues of the 1850s such as the Kansas-Nebraska Act and the destabilization of

\footnotetext{
5 Ibid.

${ }^{6}$ For more on the Nullification Crisis, especially John C. Calhoun's conception of nullification on the grounds of states' rights, see: William W. Freehling, Prelude to Civil War: The Nullification Crisis in South Carolina, 1816-1836 (New York: Harper and Row, 1966). For information regarding Andrew Jackson's response to Nullification and the issue of states' rights, see: Richard E. Ellis, The Union at Risk: Jacksonian Democracy, States Rights and the Nullification Crisis (New York: Oxford University Press, 1987). For more on the Compromise of 1850, see: Holman Hamilton, Prologue to Conflict: The Crisis \& Compromise of 1850 (Lexington: University of Kentucky Press, 1964); John C. Waugh, On the Brink of Civil War: The Compromise of 1850 and How it Changed the Course of American History (Wilmington: Scholarly Resources, Inc., 2003).
} 
the party system. The nostalgic memories that solidified in the early 1850 s continued discontent with a new generation of politicians who failed to reach the supposed standards set by the "mighty pillars" of the second generation. Their deaths at the onset of the decade not only left the country in mourning, but also searching for new politicians with the manliness, patriotism, and courage to put their country ahead of political humbuggery and personal ambition. Ultimately, the idealized memories that formed were a product of the concerns over the rise of democracy. ${ }^{7}$

Concerns regarding the condition of democratic political culture surrounding the Election of 1852 did not just emerge from the minds of eulogists. The Election of 1852 , in which both parties focused heavily on concepts of manhood and character, exemplified what Americans feared - unqualified or weak-minded candidates who obtained their nominations by being merely "available" in the eyes of their parties. ${ }^{8}$ Dismay with democratic culture continued after Democrat Franklin Pierce won this uninspiring election over Whig nominee Winfield Scott. Citizens lamented the apparent lack of politicians who would put the country ahead of personal and party ambitions. The public's belief that a new generation of politicians broke from the country's republican past intensified with their unwillingness to remember that previous politicians held those

\footnotetext{
${ }^{7}$ There is a vast amount of scholarship focusing on the causes of disunion. Two of the most thorough studies done on the political crisis during the antebellum period are David Potter's The Impending Crisis 1848-1861 and William Freehling's two volumes The Road to Disunion. While both books give excellent overviews, both neglect sufficient attention to Franklin Pierce and his presidency. In Freehling's two volumes, he devotes only 10 pages to Pierce. With the significant policies that led to sectionalism occurring during Pierce's presidency, neglecting to give due attention to Pierce, and the public's mistrust of politicians due to his policies, is a critical error. Sean Wilentz's The Rise of American Democracy: Jefferson to Lincoln is also a good study of antebellum politics. Wilentz dedicates more attention to Pierce than the other two mentioned. While all three studies are fantastic political narratives, all fail to incorporate cultural implications to help explain the political culture during the antebellum period. They neglect gender identity, ideologies of ambition and character, and memory in understanding American politics. For more opinions on new approaches for political history, see: Jeffery L. Pasley, Andrew W. Robertson, David Waldstreicher, eds. Beyond the Founders: New Approaches to the Political History of the Early American Republic (Chapel Hill: University of North Carolina Press, 2004).

8 "Capability and Availability" (New York: Lith. \&. published by Nathaniel Currier, 1852).
} 
same ambitions. While eulogists and the public more generally nostalgically remembered past generations of national politicians who had earned their trust, trepidation continued as slavery's extension into the territories raised concerns about the corrosion of republican institutions and the lack of trustworthy statesmen to rise up from the demagogic political culture that democracy produced.

In the aftermath of their deaths, the public mourned the loss and exalted in the achievements of the Great Triumvirate. In particular, following the deaths of Clay and Webster just months apart in 1852 , eulogists across the country began a process of constructing an image of the triumvirate that emphasized the trust they had in them as a collective. While speaking at the request of the Clay Monumental Association of Ohio, Whig Charles Anderson, a lawyer and future governor of Ohio, used his oration to solidify Clay's connection with Webster and Calhoun. "They have been justly called the great triumvirate of American intellect," proclaimed Anderson, who proceeded to state, "for my judgment, three minds of equal eminence, and occupied in the same arena at the same time, could scarcely be found more unlike than these." Anderson, like many other eulogists, nostalgically promoted and linked the three men together. ${ }^{9}$

Eulogies, sermons, and newspapers reminiscing about the three often characterized their attributes in such a way so that each could be superior to the others in intelligence, eloquence, or charisma. The efforts by eulogists to promote Webster, Clay, and Calhoun in such an idealistic way was akin to the form of demagoguery they admonished during their memorials. While orators deplored the demagogic state of politics, they mirrored those tactics in praising the Great Triumvirate. Eulogists intended

\footnotetext{
${ }^{9}$ Charles Anderson, A Funeral Oration, on the Character, Life, and Public Services of Henry Clay. Delivered in Cincinnati, Nov. 2, 1852, at the Request of the Clay Monumental Association of Ohio (Cincinnati: Ben Franklin Office Print, 1852), 12-13.
} 
the public to see them as a "perfect contrast" to one another. ${ }^{10}$ During Anderson's funeral oration for Clay, he made certain to compare attributes and explain how each was superior to the others in some capacity to allow praise of them all without overshadowing the others. ${ }^{11}$ Eulogists argued that the public disagreements of Webster, Clay, and Calhoun did not lessen their importance to America's political past. "These three men have stood side by side for many years in the highest places," one Philadelphia journal eulogized, "and though differing in opinions, and contending for hostile policies, neither was thereby less great." ${ }^{12}$ According to Baptist Reverend G.W. Samson, "Mr. Webster alone was great in every department of intellectual power. There was Mr. Calhoun, the close, abstract logician" who "inspired with the earnestness of sincerity." Samson asserted that Clay was the "sagacious politician and winning orator." 13

Highlighting the differences between Webster, Clay, and Calhoun gave eulogists an opportunity to praise the Triumvirate's attributes in hope that they would transcend the current state of the political culture. At the request of the Select and Common Councils of the City of Philadelphia, William Allen, president of the Girard College for Orphans, delivered a eulogy for Daniel Webster in which he detailed how Clay's and Webster's personalities varied from one another. "In general intercourse with society there was a striking contrast between Mr. Webster and his illustrious, Mr. Clay" he proclaimed. Allen contended that Clay's personality made him the most popular man in Washington society, yet that was a distinction that Webster "never attained and never sought." He

\footnotetext{
10 "Miscellaneous" Christian Observer, July 1, 1854.

11 Anderson, A Funeral Oration, 12.

12 “John C. Calhoun; Henry Clay; Daniel Webster” Plough, the Loom and the Anvil. December 1852.

${ }^{13}$ G.W. Sampson, The Providence of God in Raising up under our Republican Institutions, Great and Good Men as our Rulers: A Discourse Delivered by Rev. G.W. Sampson, Pastor of the Baptist Church, Jamaica Plain, Mass., on Thanksgiving Day, Nov. 25, 1862 (Boston: Ticknor, Reed, and Fields, 1852 ), 8.
} 
proceeded to note the contrasting ways in which Webster and Clay went about dealing with important political issues. There was little of substance in terms of highlighting the actual contrast in style and personality of Webster, Clay, and Calhoun; rather, eulogists like Allen crafted nostalgic memories that obscured the personalities of the three men and their careers within democratic political culture. In doing so, eulogists resorted to demagogic tactics in order speak out against those very tactics. ${ }^{14}$

The acts of remembering the Great Triumvirate went beyond just the admiration of the characteristics held by Webster, Clay, and Calhoun. Examining this process of mourning also illuminates the stronghold of republican ideology that the eulogizing class still clung to in the early part of the 1850s. Public reaction to the deaths of William Henry Harrison in 1841, Andrew Jackson in 1845, and John Quincy Adams in 1848, illuminated a continued strain of antiparty spirit running through the nation well into the 1840 s. By the death of the Great Triumvirate, eulogists continued to look at the political establishment with concern. They opined that Webster, Clay, and Calhoun were not only brilliant orators with great intellect- they were men who put the nation above any political party or faction. Political parties by the 1850 s had gained greater acceptance as viable means to promote initiatives, but there remained a distrust and fear that political factions endangered the republican spirit of the Revolutionary era.

The loss of the Great Triumvirate and what it meant for America's republican government reached beyond the boundaries of the United States. Daniel Barnard, U.S. Minister to Prussia, lamented the loss of Webster and Clay for American democracy while at a memorial ceremony in Paris. "CALHOUN is dead. CLAY is dead. And now

\footnotetext{
${ }^{14}$ William H. Allen, Eulogy on the Character and Services of the Late Daniel Webster, Pronounced at the Request of the Select and Common Councils of the City of Philadelphia, January 18, 1853 (Philadelphia: Crissy \& Markley, Printers, Goldsmiths Hall, Library Street, 1853), 46-48.
} 
WEBSTER is dead also...the bride hath lost her husband; the children are fatherless!" he exclaimed at the service. Barnard's words illuminate the tense relationship between the American elite and democratic government. Eulogists still had concerns about whether "the people" could make wise decisions without great men to lead them, and doubt emerged whether the public could elevate future great men amid politics and party factions that encouraged demagoguery. ${ }^{15}$

Public mourning for the Great Triumvirate enhanced the antiparty sensibilities that had been persistent in the country since its inception. Reverend R.H. Richardson used his Thanksgiving sermon for his Chicago congregation in 1852 to lament the loss of Clay and Webster to the nation. "They are dead indeed, but only as dead as great men can only die," he observed while highlighting the gift of great leaders God had bestowed on the country. ${ }^{16}$ Although initially speaking of Clay and Webster, Richardson thought it important to bring Calhoun into the discussion as well. Together, the three men for decades put the nation above partisanship and personal ambition. "I speak not of them as partizans, but as patriots; as men whose services were no more limited by their political

\footnotetext{
${ }^{15}$ Daniel Barnard, Daniel Webster: Speech of Mr. Barnard [American Minister to Berlin] Delivered at A Meeting of Americans in Paris, on the $16^{\text {th }}$ of November 1852 (Berlin: C. \& F. Unger, 1853), 9. The speech is also cited in: Merril D. Peterson, The Great Triumvirate: Webster, Clay, and Calhoun (New York: Oxford University Press, 1987), 494. Copies of his speech in Paris became available across and United States and in Berlin for Americans mourning the loss abroad. Other countries felt the loss of the Great Triumvirate as well. The Boston Daily Atlas reprinted a eulogy delivered in the Greek House of Representatives for Henry Clay and Daniel Webster and sought ways to honor the two statesmen. "Among our benefactors, then, are numbered, since 1822, the ever-memorable D. Webster and H. Clay, whose death a whole nation-The people of the United States - this day lament," noted the Greek eulogist. She continued, "Let us therefore, honorable representatives of the Greek nation, unite our tears with those of our noble brother, the citizens of the United States, for this loss," and then urged the Representatives, in proof of their gratitude to, "inscribe on the walls of this peribolus [sic] the glorious names of the Philhellenes, Daniel Webster and Henry Clay." Webster's and Clay's influence and advocacy for democratic republics stretched beyond the borders of the United States, as their struggle for the form of government had global appeal. See: "Greek Eulogy on Clay and Webster" The Boston Daily Atlas, September 26, 1853.

${ }^{16}$ R.H. Richardson, National Bereavements. A Discourse, Delivered in the North Presbyterian Church, of Chicago, on Thanksgiving Day, Nov. 25, 1852 (Chicago: S.C. Griggs \& co., 1852), 6.
} 
relationships, than their frame is "hemmed in by state lines," he declared. "Carolina Kentucky - Massachusetts: these were but the homes from which they came from to bless the nation," he noted while stressing the importance of the three men to the nation, and not to a section or party. To Richardson, only party prejudices could cloak one's awareness of the recognition that Webster, Clay, and Calhoun deserved. To memorialize the three helped to create nostalgic memories that did not alienate a section of the country. ${ }^{17}$

High voter turnout and democratic participation in party parades, celebrations, and other gatherings has been the focus of historiographical interpretations of the twoparty system during the antebellum era. The large percentage of voter turnout does not equate to an acceptance of the two major political parties. Citizens sought candidates whom they could trust - men who were not enslaved to the demands of the political parties. In his eulogy of Webster delivered to the Albany Medical College, Augustus Rawlings made certain to emphasize Webster's status as a man above parties. "All men will feel his loss," he declared, while going on to note that "Party considerations are forgotten; for remember he was bound down by no party...he was sectional in nothing, national in all things." ${ }^{18}$ As sectional tensions escalated, the public looked back fondly at the political battles of the Great Triumvirate in the first few decades of the century. Just two years after politicians, who were viewed as extreme, pushed the country to the brink of disunion, the nostalgic memories of Webster, Clay, and Calhoun as nonpartisans gave citizens hope that future sectional tensions could also be thwarted. For Rawlings, the eulogy was also an appropriate moment to connect him to Henry Clay. In his estimation,

\footnotetext{
${ }^{17}$ Ibid., 7-8.

${ }^{18}$ Augustus Rawlings, Eulogy on Daniel Webster, Delivered before the Students and Friends of the Albany Medical College. Friday, Oct. $28^{\text {th }}, 1852$ (Albany: J. Munsell, 58 State Street, 1852), 11.
} 
Webster and Clay represented an age that cared more for the country than any political affiliation. "These two men, antagonists in partizans' eyes, admired each other's greatness," and he continued to state that "they belonged to the same party - their country." 19 To dismiss praise given in a funeral oration for a politician's patriotism as obligatory admiration overlooks the deeper meaning of remembrance. The words and intentions of the orations illuminate a eulogizing class still grappling with the loss of trusted "great men" and what it meant for a republican government operating in a democratic political culture. Eulogists understood that orations for deceased politicians should give praise, but it does not mean these sources lack insight into the political culture of the antebellum period. As historian Mark Neely observes, eulogies tell us more about the mourners than the mourned. In the antebellum era, eulogists crafted rosy stories about their deceased political leaders to obscure the realities of democracy. ${ }^{20}$

The remembrance of national leaders provided a way for eulogists to participate politically in nontraditional ways. To memorialize such men as Webster, Clay, and Calhoun was not simply a time to reminisce about a golden age of politics, but of characteristics and attributes that were essential for all citizens in a republican government. Unitarian Reverend Orville Dewey, an educator for the Lowell Institute, believed that too many Americans neglected their roles as republican citizens. "There is a class of persons in this country, and I fear it is an increasing class, who, disgusted with politics, or fastidiously averse from free mingling with the people, or engrossed with

\footnotetext{
${ }^{19}$ Ibid., 13. For similar sentiments regarding Clay as a patriot who transcended party spirit and was a national statesman, see: John S. Chadbourne, The Mortal and the Immortal: A Sermon, Preached in St. James; Church, Baton Rouge, in Improvement of the Character and Death of the Hon. Henry Clay (New Orleans: Picayune, 1852), 10-11.

${ }^{20}$ Mark E. Neely, Jr. "American Nationalism in the Image of Henry Clay: Abraham Lincoln's Eulogy on Henry Clay in Context," Register of the Kentucky Historical Society 73, 1, (January 1975): 34.
} 
business, are shrinking from their duties as citizens," lamented Dewey. ${ }^{21}$ He proceeded to reminisce about the memory of past national statesman and a lost era of politics, noting how the memory of politicians changed over time. He observed that public perception had changed after the Triumvirate's death in a similar way that it did after the deaths of Thomas Jefferson and John Adams. According to Dewey, even the Triumvirate's opponents acknowledged that the Triumvirate "loved their country; and that in the circumstances in which they were placed, they did what they thought was right." To Dewey, the constructed memories formed should be a message to citizens to distrust party clamor and to be active republican citizens. Dewey used his sermon to preach his own political desires to his listeners. Like other eulogists, he raised concerns about citizens doing their duties and having the virtue to properly elect the right men to public office. $^{22}$

Multitudes of orations concealed the partisanship of Webster, Clay and Calhoun in order to elevate them into a position above party politics. To do so was not simply an attempt to simplify the past, but to keep the memories of deceased national leaders from becoming pawns in the designs of political factions. "The great men of our land, belong not to a party, but to the nation, and that for them a nation will mourn," claimed Maryland Reverend F.R. Anspach in a sermon on Henry Clay after his death. ${ }^{23}$ He made certain to remove the party label from Clay and portray him as a national man rather than a party leader. For Anspach, Clay's death was akin to the reaction after the deaths of

\footnotetext{
${ }^{21}$ Orville Dewey, On Patriotism: The Condition, Prospects, and Duties of the American People, a Sermon delivered on Fast Day at Church Green, Boston (Boston: Ticknor and Fields, 1859), 6.

${ }^{22}$ Ibid., 11.

${ }^{23}$ F.R. Anspach, A Discourse Pronounced on Sabbath Evening, July 4, 1852, in the Lutheran Church of Hagerstown, on the Death of Henry Clay (Hagerstown: Mittag \& Sneary, 1852), 4. For similar sentiments, see: Isaac N. Shannon, Divine Providence in American History and Politics: A Discourse Delivered in the Second Presbyterian Church, New-Brunswick, N.J., July 4, 1852 (New-Brunswick: A. Ackerman, Publisher, 1852), 23.
} 
George Washington and Andrew Jackson. As with public reaction to the two former generals and presidents, Anspach believed Clay's grave "will be a hallowed spot, a shrine for pilgrims, and around it, will the children of the nation gather, and unborn generations will tread softly" when they "seek the tomb of a patriot." Only death could obscure the political differences between Clay and Jackson for a new narrative of national heroes above petty partisanship. ${ }^{24}$

Thomas Davis, a lawyer in Syracuse at the time of Webster's death, delivered a eulogy that separated Webster from the destructive nature of partisanship. Davis wanted to speak of Webster, "not as a Massachusetts man, not as a Northern man, but as AN AMERICAN." In his estimation, Webster's career on the national stage elevated him above political squabbling. He desired to "bury in the deep obscurity of the tomb," any party feeling or local prejudice, and hoped Webster's life could teach about the "immeasurable superiority of genuine patriotism to the evanescent claims of party or sectional interests." It was up to citizens to learn from Webster's example and to look beyond political parties when making decisions. Davis's eulogy, as with other orations for members of the Great Triumvirate delivered by citizens not in or associated with Congress, did not ignore party politics. Rather, Davis's oration intentionally referenced the harm that party politics can inflict on a republic without great leaders to rise above the highly partisan democratic culture. Whigs and Democrats speaking about lessening the hold of political parties in orations for Clay and Webster was not necessarily an attempt by Whigs to obliquely promote the party through the remembrance of their careers, or of Democrats giving false admiration to a foe who no longer posed a threat. Public displays of remembrance allowed eulogists to confront a political system that had moved away

${ }^{24}$ Ibid., 5. 
from the republican spirit of the Revolution. Public reminders of national politicians who supposedly put the country and the constitution first gave hope that republican ideals could triumph over the political and sectional extremism fostered by democracy.

Public mourning for the loss of the Great Triumvirate renewed a process of constructing a memory of not only their careers but also the political events of which they stood at the forefront. Two volatile debates potentially led to disunion: the Nullification Crisis in the early 1830s and the Compromise of 1850 . Citizens reconsidered the meaning of those divisive debates since Webster, Clay, and Calhoun were leading figures during those tumultuous periods. Although the three men, especially Calhoun, had an important role to play in the controversy, many eulogists remembered the debates as a clash among giants who sought what they believed was best for the country. The nostalgic memorialists of the debates questioned if the country could again overcome issues that endangered the nation.

Eulogists who highlighted nonpartisan moments in the careers of the Great Triumvirate illuminated the present concern about political factions controlling politicians and enabling demagoguery. Ira Perley dedicated much of his eulogy for Daniel Webster to discuss his ability to look beyond the wants of sections and political parties and do what was best during trying times. Perley did not believe Webster was a "party man." That did not mean that Webster did not respect the basic tenets of his party. "He broke no party pledge, he abandoned no maxim or principle of the party to which he belonged," he claimed. Perley portrayed Webster as a man who always put the Union first, and understood that the constitution originated from concession and compromise. For this reason, he was ready to sacrifice sectional, personal, and party interests. 
According to Perley, a true display of Webster's devotion to the Union came during the Nullification Crisis when he worked with party adversary, Andrew Jackson. Webster and Jackson, despite being leaders of the two major parties, embodied the character needed to find compromise for the benefit of the nation. Webster and Jackson put aside their differences and guided the country to safety as John Calhoun and other states' rights advocates promoted the Doctrine of Nullification. ${ }^{25}$

Webster became a leading voice of a nationalist criticism of the idea of nullification as the debate raged in the early $1830 \mathrm{~s}$. He rejected the premise of compact theory and argued that the constitution was created for "the people" and that states were subordinate to the federal government. ${ }^{26}$ His most celebrated advocacy of the nationalist interpretation regarding nullification came during a debate with Robert Y. Hayne of South Carolina. William Allen's eulogy described the battle of nullification as a "war of giants. ${ }^{27} \mathrm{He}$ reminded his listeners that Andrew Jackson intended to implement the Force Bill, and the reaffirmation by Hayne and Calhoun of the South Carolina Doctrines. It was Webster's response to the latter that Allen considered, "the most perfect constitutional argument ever constructed." In Allen's estimation, Webster's speech in response to Hayne, "gave the death blow to nullification; for though it lingered awhile, it was past all medical skill. ${ }^{, 28}$ For many eulogists, Webster's remarks silenced the divisive issue that threatened the Union and helped find a compromise between the two sides. In

\footnotetext{
${ }^{25}$ Ira Perley, Eulogy of the Hon. Ira Perley, on the Late Daniel Webster, pronounced before the Executive and Legislative Departments of New Hampshire, December 22, 1852 (Concord: Butterfield \& Hill, State Printers, 1852), 29, 30, 32.

${ }^{26}$ Ellis, The Union at Risk, 9. Ellis details the two different sources opposing the doctrine of nullification. In addition to the nationalist interpretation championed by Webster, Ellis also identifies traditional proponents of states' rights who also questioned nullification. While this camp typically did subscribe to the compact theory in some capacity, they denied South Carolina's argument that states were completely sovereign entities.

${ }^{27}$ Allen, Eulogy on the Character and Services of the Late Daniel Webster, 33.

${ }^{28}$ Ibid., 34.
} 
his eulogy for Webster delivered at Odd-Fellows' Hall in Memphis, Tennessee, Leroy

Pope, Jr., echoed Allen's sentiment and pointed to Webster's reply to Hayne in 1830 as a moment for national pride and a growing confidence in Webster as an orator and defender of the constitution. Pope reflected upon the national advancements in the twenty-three years since the crisis. The reason for such improvements was due to the preservation of the Union, and for that, he credited Webster. Pope praised Webster for saving "all these things from the night of perpetual gloom and annihilation!"29

The public mourned the passing of Webster, Clay, and Calhoun in the midst of conceptualizing the bitter debates of 1850 , a time when anxiety over the possibility of disunion engulfed much of the nation. With California set to enter the Union, concerns about an imbalance in the senate between free and slave states again came to the forefront. Fears of disunion and what that meant for the nation became paramount. Politicians mostly hailing from the Deep South matched Calhoun's ferocity over southern rights. In response, a growing minority of northern politicians no longer thought it necessary to give in to the Slave Power's threats and held steadfast in hope of passing David Wilmot's Proviso. After President Taylor's plan for compromise failed, citizens looking for a resolution for the crisis turned to Henry Clay, who already garnered the nickname of "The Great Compromiser." Clay proposed a resolution in the form of eight proposals meant to appease the concerns of both sections. While the public hailed Clay for his endeavors, the proposals had little chance of passage, and Congress began the long

\footnotetext{
${ }^{29}$ Leroy Pope, Jr., A Eulogy, Upon the Life and Public Services of Daniel Webster, by Leroy Pope, Jr., esq. Delivered at Memphis, Tenn., on the $28^{\text {th }}$ Feb., 1853 (Memphis: Eagle and Enquirer Steam Printing House, 1853), 14, 15. In a similar vein as Ira Perley's eulogy, Pope, linked Andrew Jackson with Webster. He reminisced romantically about clash of "gallant politicians" who debated the issue Although the belief in nullification "was kept alive by the splendid, and the resistless force of the personal character of John C. Calhoun," it was Webster's remarks that rescued the country from ruin (page 16).
} 
process of reworking his suggestions. Because Calhoun's health had rapidly declined at this stage, he had James Mason of Virginia read his speech on the issue - Calhoun's last address to the senate on March 4, 1850. Disunion played a prominent role in his speech, and he warned of the growing danger if the North did not repudiate the antislavery agendas of extremists and be true to its rhetoric of love for the Union. ${ }^{30}$

The eyes and ears of the nation were on Daniel Webster as he prepared to deliver a speech on the issue just a few days after Calhoun's address. For "godlike" Daniel, a nickname given to him by supporters after his powerful eulogy delivered after the deaths of Thomas Jefferson and John Adams, this was now set to be a defining moment in his illustrious career. ${ }^{31}$ Webster delivered a pro-compromise rebuttal to Calhoun's address. Many antislavery northerners hoped that Webster would champion the cause of fighting against slavery's expansion, but he berated abolitionists as well as southern rights advocates for losing touch with the true intentions of the founding generation. $\mathrm{He}$ continued to charge that disunion was a design of fanatics in both sections and he refuted Calhoun's remarks that disunion was natural. He spoke unequivocally of the dangers and foolishness of disunionist talk by both sections. ${ }^{32}$

Webster received mixed results from his pro-compromise address. Many conservative newspapers, politicians, and citizens lauded his speech, but it left strong opponents to slavery's expansion frustrated with a missed opportunity to have the nation's preeminent statesman strike a critical blow to the Slave Power. Some northerners

\footnotetext{
${ }^{30}$ Historian Elizabeth Varon notes how during this period members of Congress used the discussion of disunion as a process and as a program, and that during these debates, northern and southern representatives increasingly came to distrust each other. See: Elizabeth R. Varon, Disunion! The Coming of the American Civil War, 1789-1859 (Chapel Hill: University of North Carolina Press, 2008), 212-213. 216.

${ }^{31}$ Robert V. Remini, Daniel Webster: The Man and His Time (New York: W.W. Norton and Company, 1997), 266.

${ }^{32}$ Varon, Disunion!, 217-219.
} 
perceived Webster's address supporting Clay's compromise as selling out his convictions on slavery in order to procure support from southerners in anticipation of a possible presidential run in 1852 . Webster's reputation at the time took a hit among some northerners who hoped his address would further the antislavery cause. The fears of disunion that engulfed the nation remained fresh on the minds of citizens as they mourned the loss of the Great Triumvirate. As newspapers, pulpits, funerals, and gatherings memorialized the Great Triumvirate, they also re-examined the meaning of the disunion crisis of 1850. For many, even those who opposed Webster and Clay's stance on the issue, the political present affected the memories of the crisis. Memorialists held contempt for the paeans of compromise when they were issued, but pined for them after the Whigs seemed to be disintegrating over slavery. Memories began to change in order to fit perceptions of the illustrious statesmen after their deaths and to silence continuing voices of opposition that challenged those nostalgic memories.

Eulogists discussed the disunion crisis at such length in large part because of similar political concerns in 1852 amid the deaths of Clay and Webster. Citizens were concerned about the present state of politics, which made looking to the past and crafting particular memories of similar previous disputes so important to them. "What manner of man was required to meet such a crisis, and to avert disunion and national suicide?" William Allen asked his listeners as he reminded them how close the death of the nation was during the crisis. Allen exclaimed that a great statesmen was required; a man who stuck to his convictions even if temporarily unpopular, and who "could oppose his party if his party were wrong, and go hand in hand with political opponents when they were 
right." ${ }^{33}$ Allen sought to silence possible threats to his idealistic interpretation. He argued that the disunion crisis did come close to tearing the country apart, and Webster sacrificed his reputation in order to do what was best for the Union. Allen's oration encapsulated the antidemocratic and sometimes demagogic nature of sermons and eulogies in the antebellum era. He hailed Webster as a republican leader and urged a return the country's republican roots even as Allen took part in a democratic debate to rail against democracy. Allen left no room for debate on his interpretation of Webster and attempted to silence opposition to his idealistic memory. ${ }^{34}$

Webster and Clay became symbols of republican statesmen who embodied the hope that the political extremism that democracy cultivated could be squelched by genuine compromise. The reminiscence of Clay's and Webster's selfless stand for compromise became even more important considering the legitimate concerns of disunion in the minds of citizens throughout the country. Orations in honor of Webster and Clay focused on their devotion to preserve the Union during the 1850 crisis. Leroy Pope, Jr. contrasted the character of Webster and Clay with the negative influence of democracy. "Slavery, and its kindred and collateral topics, had roused every malignant demon of faction, North and South," he declared during his eulogy. He placed the blame for the tension on "fire eating secessionists and abolition disunionists" who lost "all sense of past glory, all veneration for the great names of history." During the period of fanaticism and disunionist threats, however, he argued that Webster and Clay appeared as chosen instruments in the hands of God to guard the Union. With the country at the brink of disunion, "it was then, that Webster and Clay, while the storm of fanaticism was

\footnotetext{
${ }^{33}$ Allen, Eulogy on the Character and Services of the Late Daniel Webster, 16-17.

${ }^{34}$ Ibid., 35.
} 
beating upon one end of the Capitol, and the lightnings of discord streaming in at the other," that they laid their hands on the ark of the constitution, and "with a godlike serenity, lifting their voices above the roar of faction, silenced the tempest, and quenched the wrath of the thunderbolt!" ${ }^{35}$ Similar to when Pope described the nullification crisis, he continued to link Webster, Clay, and Calhoun together, despite the disagreement that Calhoun had with Webster and Clay. Despite their differing views, he glossed over the reality of the debate between the men and praised the "splendid triumvirate" and character of their eloquence. $^{36}$

Admiration for the Great Triumvirate, and especially the struggle to preserve the Union by Webster and Clay, did not mean ignoring slavery's significant role in the crisis. In his study examining orations after Clay’s death, Mark Neely notes that of the twentytwo members of Congress who eulogized Clay, the word "slave" only appears once in 135 pages. ${ }^{37}$ Focusing on sermons and eulogies delivered outside of Congress sheds light on how eulogists called "the people" into being in order to promote their desired cultural narrative that registered concerns with aspects of democracy. Eulogists praised Webster, Clay, and Calhoun and highlighted the importance of commemoration for understanding

\footnotetext{
${ }^{35}$ Pope, Jr., A Eulogy, Upon the Life and Public Services of Daniel Webster, 16-17.

${ }^{36}$ Ibid., 21-22. For similar sentiments on Clay and Webster saving the Union from threats of disunion, see: Ogden Hoffman, Oration of Ogden Hoffman, United States District Judge, at the Celebration of the Obsequies of Henry Clay, by the Citizens of San Francisco, California, August 10 ${ }^{\text {th }}, 1852$, and the Proceedings of the United States Court on the Reception of the Mournful Intelligence of his Death (New York: Daniel Fanshaw, 1852), 10, 11-12. Clay also received praise for coming out of retirement in order to help save the country from ruin. For sentiments on Clay's republican virtue for doing so, see: Geo. A. Leakin, A Sermon on the Death of Henry Clay; Preached in Trinity Church, Baltimore, on $7^{\text {th }}$ Sunday after Trinity, 1852, by Rev. Geo. A. Leakin, A.M. (Baltimore: A.P. Burt, 1852), 5.

${ }^{37}$ Neely, Jr. "American Nationalism in the Image of Henry Clay,"41-42.
} 
present political disputes. Eulogists used idealistic memories of those past controversies to promote their particular vision of slavery's existence in democracy. ${ }^{38}$

Henry Clay's position on the 1850 crisis came as no surprise to many northerners considering he was a slaveholder, but it was more difficult for antislavery northerners to come to terms with Webster's position. Many eulogists justified Clay's stance in 1850 as not a betrayal of his conscience, but as a courageous stand for the preservation of the Union and constitution. Thomas Davis tackled the issue of Webster and charges of his oscillating stance on slavery during his eulogy. "The idea that DANIEL WEBSTER was the friend of slavery, is repudiated by his whole history. He was its enemy. He deplored its existence- he sought to limit its domain," Davis exclaimed in defense of Webster's address, and pointed to his past opposition to Texas annexation as evidence that he stood strong against the Slave Power. He contended that the Nashville Convention, which discussed the idea of southern rights and secession, showed the danger to the Union against which Webster fought. "Southern statesmen, as if in insult to the illustrious dead, were assembling by the grave of Andrew Jackson to sunder the last ties which bound the North and South, the East and West together in the unity of the Republic," he claimed. Davis continued, "I do not say that disunion would have resulted from the prohibition of slavery in the new territory; but Mr. Webster feared it-it was by no means impossible," and argued that Webster understood that disunion would also entail violence for the

\footnotetext{
${ }^{38}$ For an example of slavery's connection to the crisis, see: J.N. M'Jilton, God's Footsteps: A Sermon delivered in St. Stephen's Church, Baltimore, July 4 ${ }^{\text {th }}$, 1852, the Sunday Succeeding the Death of Hon. Henry Clay (Baltimore: G.W. Magers, 1852), 16. For sentiments on Clay's role in the compromise, see: Chadbourne, The Mortal and the Immortal, 11-12.
} 
Union. According to Davis, Webster abhorred slavery but believed the debate was unnecessary because the geography was not suited slavery. ${ }^{39}$

Eulogists emphasized the importance of mourning for national leaders and it indicated much about their desires for the time in which they lived. Orations in honor of Webster did not mean simply heaping admiration on his career. Northern citizens disappointed by Webster's remarks did not dismiss his position during the crisis of 1850 . At times, they did criticize Webster but showed an understanding for his motives. Educator and Unitarian Minister A.D. Mayo's sermon focused on slavery. "I do not excuse the errors of his judgment, or his life," Mayo asserted, but continued to point to Webster's republican spirit for finding resolutions even when it angered some. ${ }^{40}$ "Webster was sent to prevent America from coming to some violent end before she was a century old," he declared, concluding, "he has done his work." Justifying Webster's position during the crisis of 1850 as a sincere attempt to preserve the Union allowed for citizens to rationalize his stance on slavery through the lens of republican ideals. It also provided a conservative interpretation to reconcile slavery's existence within a democratic nation. Orators consistently emphasized their detachment from political parties. Speakers believed that there was a receptive audience for antiparty and nonpartisan sentiment. ${ }^{41}$

\footnotetext{
${ }^{39}$ Davis, Eulogy on Daniel Webster, 19-20. For similar sentiments in defense of Webster's position on the Compromise of 1850, see: Thomas Starr King, The Death of Mr. Webster: A Sermon Preached in HollisStreet Meeting-House, on Sunday, Oct. 31, 1852 (Boston: Benjamin H. Greene, 1852), 24-25; Otis A. Skinner, The Death of Daniel Webster: A Sermon, Delivered in the Warren Street Church, Sunday, November 14, 1852 (Boston: A. Tompkins, 1852), 12-13.

${ }^{40}$ A.D. Mayo, A Sermon on Daniel Webster, preached at Gloucester, Mass (Gloucester: John S.E. Rogers, 1852), 11.

${ }^{41}$ Ibid., 12. For similar sentiments, see: Nehemiah Adams, A Sermon Preached to the Congregation at the Essex Street Church, October 31, 1852, the Sabbath after the Interment of Hon. Daniel Webster, by Nehemiah Adams, D.D., Pastor of the Essex Street church, Boston (Boston: Geo. C. Rand, Cornhill, 1852),
} 
Not all eulogists took a conservative approach in pardoning Webster for his controversial position on slavery during the crisis. Many sermons and eulogies looked admirably at Webster and Clay for preserving the Union, whether they agreed with the compromise or not, yet there were some with more ardent antislavery views who could not forgive Webster for his perceived betrayal. The antislavery newspaper The Pennsylvania Freeman reprinted a letter by Reverend William M'Calla in which he condemned the Great Triumvirate for its position on slavery, and noted that each member died a martyr for the peculiar institution. "John C. Calhoun spent his life, and hastened his death by zeal for the southern institution," M'Calla claimed and continued to note, "Henry Clay, an emancipator, and an advocate of Jeffersonian abolition, marvelously died a martyr in the same cause," when speaking of the struggle for slavery. Regarding Webster, "the friend of liberty, and witness against slavery, strangely suffered martyrdom in the same cause." M'Calla concluded that "these great men have bound their northern brethren not only to the law of passive obedience and non-resistance, but to an active participation in the southern evil." M'Calla echoed the pulse of antislavery northerners who were unhappy with the Fugitive Slave Act, which was part of the compromise. ${ }^{42}$ Speeches regarding the compromise and the attack on northern liberties by the new legislation persisted throughout the 1850s. Even after the passing of the Great Triumvirate, the more outspoken abolition and antislavery advocates continued to criticize Webster, Clay, and Calhoun for their involvement. In looking to the future after Webster's death, Frederick Douglass' Paper argued that "the nation has been a prisoner; and Calhoun, Clay, and Webster, have been the chains and clogs that overcome its power

8; Roswell D. Hitchcock, A Eulogy on Daniel Webster, Delivered Before the Students of Bowdoin College, on Friday, Nov. 12 ${ }^{\text {th }}, 1852$ (Brunswick: J. Griffin, 1852), 32-33.

42 "Rev Wm L. M'Calla in Vindication of Uncle Tom" The Pennsylvania Freeman, June 30, 1853. 
of locomotion. ${ }^{43}$ When speaking to the American antislavery society, William Lloyd Garrison stated, "since we were here last the three great champions of slavery have gone to dust. Their bodies are entombed and their souls gone to God. Where is John C. Calhoun? Where is Henry Clay? Where is Daniel Webster?" Abolitionists did not alter their opinion of the compromise to portray the Great Triumvirate as republican heroes saving the Union. They held them up as the symbols of a corrupt democratic system that protected slavery. Orations against the Great Triumvirate received rebuke, as the Weekly Herald published Garrison's speech to show the fanaticism that threatened the Union. Various constituencies battled over who the Great Triumvirate "belonged" to in order to promote their political interests. Critical eulogists of Webster, Clay, and Calhoun are indicative of the democratic nature of the cultural act of eulogy. There was tension within the eulogizing class over political memories and their role within the political culture debating present political issues. The conflict over memory displayed by eulogists mirrored the combative nature of antebellum democracy. ${ }^{44}$

Unitarian minister Theodore Parker, a well-known Boston abolitionist, delivered perhaps the most controversial oration on Daniel Webster. His sermon displayed the tension at the heart of the cultural act of eulogy in the antebellum era. Eulogists debated issues of democracy and the meaning of the past in their orations. The eulogizing class used their eulogies to promote their vision of past political and how they wanted contemporaries to view political issues of the day. For three hours in the Boston Music Hall, Parker detailed the life and actions of Webster. ${ }^{45}$ Similar to other orations, Parker

\footnotetext{
43 “The Future" Frederick Douglass' Paper, November 5, 1852.

44 "Anniversary Week. American Anti-Slavery Society - Fanaticism Run Mad" Weekly Herald, May 14, 1853.

${ }^{45}$ Peterson, The Great Triumvirate, 492-493.
} 
quickly stated that he was free from the shackles of party loyalty. "I am no party man; you know I am not," he declared, and continued to state, "no party is responsible for me, nor I to any one.” Parker proceeded to talk about Webster's intelligence and importance to the region and lamented, more broadly, the current "dearth of great men" and the desire for Americans to revere great men and look to them in difficult times. ${ }^{46}$ As the sermon progressed, however, it became obvious to those listening that Parker was not sticking to the commonly told narrative of Webster's accomplishments. To the surprise of the audience, Parker's sermon was a sad tale of a man who lost his way. Parker believed it was his duty to watch politicians and judge their sincerity because politicians often lived according to the dictates of the ballot box. "So a minister, who would guide men to wisdom, justice, love, and piety, to human welfare," he asserted, "must watch the great men, and know what quantity of truth, justice, of love, and of faith there is in Calhoun, Webster, Clay." He stressed the importance of scrutinizing all "great men.",47

The tragic turning point in Webster's political life, according to Parker, was his position during the crisis of 1850 . "What was the design of all this?" Parker asked his listeners, and continued, "was the Union in danger?" Parker did not buy into the popular belief that Webster's March 7 was his way of saving the Union. "I think Mr. Webster knew there was no danger of dissolution of the Union," Parker opined. The question then was why Webster took such a position against much of what he had preached in the past. "Here is the reason. He wanted to be President ... he wanted the office himself. This time he must storm the North, and conciliate the South,” argued Parker. In this sense, Parker agreed that Webster, Clay, and Calhoun should remain linked in memory. "Calhoun,

\footnotetext{
${ }^{46}$ Theodore Parker, A Discourse Occasioned by the Death of Daniel Webster, Preached at the Melodeon on Sunday, October 31, 1852 (Boston: Benjamin B. Musey \& co., 1853), 2-3.

${ }^{47}$ Ibid.,10,12.
} 
Clay, Webster - they were all able men, - long in politics, all ambitious, grasping at the Presidency, all failing of what they sought," he declared about the Great Triumvirate. While Parker broke rank with other eulogists in his condemnation of the Triumvirate, he nonetheless voiced similar concerns about democratic culture as he placed Webster, Clay, and Calhoun within that culture rather than obscuring their role in it. He continued to criticize the three men for working in defense of slavery's perpetuation for personal gain. Parker lambasted Webster for his position on slavery during the 1850 crisis. As with many other orations, he noted the memorable speeches that Webster delivered at Plymouth Rock and Bunker Hill as well as his eulogy for Jefferson and Adams. Unlike others, however, Parker lamented the loss of the man who he believed sold out his morality. "The orator of Plymouth Rock was the advocate of slavery; the hero of Bunker Hill put chains around Boston Court-house; the applauder of Adams and Jefferson was a tool of the slaveholder," he declared. Webster had changed from those earlier days of his career. "I learned to hate slavery from the lips of that great intellect," Parker recalled when he was a boy listening to Webster's Plymouth Rock speech. Throughout the litany of attacks on Webster in the sermon, ultimately Webster's death in 1852 meant little. "Daniel Webster went down to Marshfield—-to die! He died of his $7^{\text {th }}$ March Speech!" Parker thundered. To Parker and other abolitionists, the Webster they knew and hoped to see champion their position died the day he gave his address in defense of Clay's compromise. Webster was no different from the other demagogues who sacrificed the greater good for personal ambitions. ${ }^{48}$ The differing memories of the Great Triumvirate

\footnotetext{
${ }^{48}$ Ibid., 63, 95, 69, 72. Many sermons and eulogies for Webster remarked upon his speeches at Plymouth and Bunker Hill. For a couple examples of his comments at Plymouth, see, George Richards, A Discourse, Occasioned by the Death of Daniel Webster, Delivered in Central Church, Boston, October 31, 1852
} 
more broadly illuminates importance of eulogies as a way to debate politics in a democracy. Just as eulogists argued about the legacies of national politicians, they also debated the meaning of democracy and present political issues. Orations allowed eulogists to define and defend their vision of American politics. Even when criticizing the democratic political culture of the era, they nonetheless helped make democracy.

Parker's sermon quickly garnered outrage throughout New England. A Free Soil newspaper printed the oration and sold eighty thousand copies, and Parker edited and printed the speech in pamphlet form. There was some support for the oration among those still bemoaning Webster's perceived betrayal of his beliefs on slavery, but it paled in comparison to the outpouring of rebuttals through various mediums that admonished Parker for his scandalous words. ${ }^{49}$ Amidst the outrage, George Osborne Stearns under the name of "Junius Americanus," published a review of Parker's speech. In direct response to Parker, Stearns wrote, “By an unheard of ferocity of attack upon a dead man's fame, in a funeral sermon, this man has put himself beyond the pale of conventional protection. He has shown no mercy to the dead, and we shall show none to him living." Stearns rebuked Parker's honesty in an almost page-by-page breakdown of his accusations. Stearns called into question Parker's sincerity about not having ties to a political party, and charged him with making attacks against the Democratic Party. "We would honestly say to honest men of the same political party with this minister, are you willing to trust such an evident trickster?" he asked. Essentially, he accused Parker of being a

(Boston: T.R. Martin, 1852), 8; Skinner, The Death of Daniel Webster, 14. Skinner references Bunk Hill on page 15.

${ }_{49}$ Peterson, The Great Triumvirate, 492-493; Junius Americanus, A Review of "A discourse Occasioned by the Death of Daniel Webster, Preached at the Melodeon on Sunday, October 31, 1852, by Theodore Parker, Minister of the Twenty-Eighth Congregational Society in Boston" (Boston: James Munroe and Company, 1853), 13-14. 
demagogue, the same critique Parker had made of Webster. He continued to criticize Parker for his negative comments about both Webster and Clay. He also condemned Parker for his supposed lack of patriotism. "We plainly discern the preacher's hostility to the Union—-his leaning towards nullification. Perhaps this Pilate of Massachusetts will make friends, and strike hands with some Herod of South Carolina, on this question," he noted while painting Parker, and more broadly abolitionists, as extremists who did not sufficiently care about the preservation of the Union. Like other defenders of Webster, Stearns accused anyone who challenged his nostalgic memory as being un-American. ${ }^{50}$

The review of Parker's speech served as a vehicle to defend the northern conservative viewpoint on slavery. "From the forty-ninth page to the end, the 'Discourse' is devoted to a consideration of Mr. Webster's course on the slavery question, and the vilest and most indecent abuse of his private character," Stearns noted before he began a long defense of slavery. He argued that slaves had better living conditions in America than in Africa and that true republicanism called for citizens to care for slaves until they could care for themselves. According to Stearns, Webster took his position on slavery because unlike abolitionists such as Parker, Webster looked out for the best interest of the nation. "He loved his country better than any party; he loved the Union better than he loved Massachusetts; he regarded the well-being of an entire nation more than the prejudices of the pseudo-philanthropist," he declared. Extremists like Parker were products of the hyper-partisan age that threatened the conservative interpretation of democracy, and slavery was a large reason why democracy posed such a threat to republican government. Stearns contended that the crisis of 1850 did pose a real threat to the Union. "There was danger. The man who denies it knows nothing of human nature,"

\footnotetext{
${ }^{50}$ Americanus, A Review, 5, 52, 53.
} 
he stated to refute the assertions of Parker on the matter. ${ }^{51}$ His position on the issue rang true for many northern citizens. The sectional conflict was not one of two contrasting civilizations between the North and South. The fate of the Union depended on individuals to either save it or cause its destruction. Many northerners, despite repudiating aspects of Webster's stance on slavery, had constructed a memory after his death that reinforced the perceived dangers of disunion lurking. It was thought, however, that it could be averted by republican statesmen like Webster and Clay who put the nation above party, sectional, and personal considerations. Despite the inherently conservative and antidemocratic nature of many sermons and eulogies, they nevertheless became a part of the democratic culture. As orations circulated in printed forms across the country, citizens read and debated the words of tribute and formed their own memories over deceased politicians and past political battles.

The mourning that occurred throughout the country for the Great Triumvirate after Daniel Webster's death had significant political ramifications. Indeed, orations for the Triumvirate did not ignore contentious political issues. The praise bestowed upon Webster, Clay, and Calhoun was not simply an attempt to deliver false admiration in spite of political shortcomings in their careers. Throughout the tumultuous party and sectional debates in the antebellum period, citizens longed for politicians who met the supposed republican standards set by the Founding Fathers. Citizens saw Webster, Clay, and Calhoun as extensions of the Founders and the leaders of a second generation of politicians. Eulogists looked to the Great Triumvirate's legacy for reassurance during an uncertain political atmosphere. The anger over divisive policies, in particular the Compromise of 1850, waned as citizens mourned the Great Triumvirate and constructed

${ }^{51}$ Ibid., 57, 76, 82. 
memories of the compromise in which it became a testament to the virtue of Webster and Clay especially. The public remembered the three as great men of character who could come together to debate and compromise for the sake of the country while maintaining their manly dignity. In some ways, citizens shared the concerns of the eulogizing class about democratic political culture. Eulogists worried that Congress now lacked national statesmen with republican virtue for all sections to have faith in when future compromises needed the nation's blessing.

As citizens mourned the loss of Clay in July and Webster in October, the Democrat and Whig parties attempted to galvanize their supporters for the Election of 1852. Democrats and Whigs attempted to garner support for their respective candidates. Issues of manliness and character gained much attention throughout the campaign, yet the candidates' platforms were largely indistinguishable. Furthermore, a belief grew among the public that both candidates were chosen merely because they were "available" and not that they had earned their nominations. Indeed, the election appeared to highlight the unseemly aspects of democracy. By taking a strong position on an issue, eminently qualified politicians eliminated their chances of obtaining their party's presidential nomination. With most of the qualified candidates ironically disqualified for having taken principled political stands, parties looked to men who did not have opinions that might anger any particular section of the country. Cartoons and editorials throughout the country lamented what partisanship, but also more broadly democratic culture, had done to America's highest office. A politician who took a stand and voiced a strong opinion on an issue displayed the manly characteristics that evoked the backbone of previous political generations, but as a result, that politician often hurt his popularity in a region of 
the country. Fearful of alienating a part of the nation, parties no longer viewed principled leaders as "available." The way to get ahead was to walk the party line. The Democrats nominated Franklin Pierce because he did not stray from mainstream party positions. ${ }^{52}$ The Whigs, still in many ways an antiparty coalition rather than a political party like the Democrats, again resorted to selecting a General, Winfield Scott, who had no political affiliations, as their nominee.

In his eulogy for fellow New Hampshire native Daniel Webster just days before the presidential election, Pierce tried to balance the competing imperatives of a culture that praised principled stands with party politics that shied from open regional conflict. He knew his words could elevate his status on a national stage just as the eulogy for Adams and Jefferson did for Webster. Throughout the eulogy, Pierce delved into the larger meanings of the passing of Webster's generation, acknowledging the doubt that he and other new politicians could successfully fill the void. Borrowing from the late Edmund Burke, Pierce exclaimed, “"what shadows we are, what shadows we pursue!' How these emphatic words come back to us here, as if by an echo!" Pierce followed the form of many eulogies for political leaders delivered by politicians. The public platform of eulogy allowed for him to portray himself as a man who could look beyond party factions. Delivering praise and making connections between him and Webster played into attempts to gain Whig support from citizens disgruntled by Scott's nomination. ${ }^{53}$

The Democrat's Review understood what the passing of the Great Triumvirate meant to Americans. To give the appearance of looking beyond party affiliation, the journal recognized the significance of the trust and admiration the country held for the

\footnotetext{
52 "Capability and Availability” (New York: Lith. \&. Pub. By Nathaniel Currier, 1852).

53 “The Great Dead" Democrat's Review, October 1852.
} 
second generation. "We have now to face the world again in this generation as if we had never been, as if we were the founders, not the heirs of liberty," he claimed, illustrating the fear that many held for these untested politicians attempting to fill positions of power. The Review did bring politics into its remembrance of Webster, however, by delegitimizing the Whigs and attaching Webster's memory to Pierce. "The Whig party have $[s i c]$ not paid him either just respect, or equivalent honors. He was their greatest man. Pierce and Webster were friends and comrades," the Review claimed, while also attaching Webster to the growing Young America movement within the Democratic Party. ${ }^{54}$ The Review believed there was a particular way parties should commemorate dead political leaders and charged the Whigs with failing to meet that standard. Mourning the leaders of the Whigs allowed partisan papers to deride the current state of the Whig Party. "Calhoun, Clay, ... Webster! The old age of the world is passing away, and the inscription of these four names may justly form its epitaph," the Review declared, tapping into the loss citizens felt and exploiting it for partisan gains. ${ }^{55}$

The increasingly powerful younger faction of the Democratic Party trumpeted Pierce as a gallant war hero and true patriot worthy of the country's highest position. ${ }^{56}$ Even though he lacked national recognition, Pierce was precisely what the Democrats were looking for-a northerner with southern sympathies who did not have enough enemies to oppose his election. He did have his faults—-he lacked self-control, suffering from bouts of depression and alcoholism that began during his youth and continued

\footnotetext{
${ }^{54}$ For more on the Young America movement within the Democratic Party, see: Yonatan Eyal, The Young America Movement and the Transformation of the Democratic Party, 1828-1861 (New York: Cambridge University Press, 2007).

55 “The Great Dead" Democrat's Review, October 1852.

56 "Sketch of the Life and Character of General Franklin Pierce" Mississippian and State Gazette, June 25, 1852 .
} 
through his career. ${ }^{57}$ The Whig Party quickly challenged Pierce's untested career and questionable character. The American Whig Review charged that "the Democratic Party, having thus been propelled by sheer necessity to abandon their well-known candidates, have $[s i c]$ as before selected a man almost unknown to the mass of the people, and therefore comparatively free from personal attack and political obloquy." ${ }^{, 58}$ The Whigs exploited Pierce's obscurity on a national stage during a time when the country still mourned the loss of the well-known and trusted Great Triumvirate. The Whigs endeavored to put forth a candidate of supposed manly character, Winfield Scott, who enjoyed national recognition for his military, rather than political, exploits.

The Whigs, attempting to regain the Executive Branch, continued their pattern of nominating nationally recognizable generals, hoping that their military record and patriotism would sweep them into the White House. Scott was the most famous American general since George Washington, though he was not an influential Whig by any means. Because his political opinions were virtually unknown, the Whig Party thought it was prudent to use his patriotic and heroic reputation and select him rather than a more politically qualified candidate. "There is everything in the character of Winfield Scott to arouse the gratitude and pride of the American People," exclaimed Whig politician John Minor Botts. "If the Democrats had even pitted against him a man that was a man! Cass

\footnotetext{
${ }^{57}$ For more on Franklin Pierce, see: Roy F. Nichols, Franklin Pierce: Young Hickory of the Granite Hills (Philadelphia: University of Pennsylvania Press, 1931). Despite publication in 1931, Nichols's biography of Franklin Pierce is still the best study conducted on him. Nichols but also accurately details the complex psyche of Pierce. Since this biography, there has been little done on Pierce and his life. The most recent work on Pierce is Peter Wallner's two volumes called Franklin Pierce: New Hampshire's Favorite Son and Franklin Pierce: Martyr for the Union. Although the most recent, both volumes are a poor study of Pierce. Wallner is determined to show that Pierce was a qualified president and is not the poor, anti-Union president that Nichols, and other prominent scholars throughout the early $20^{\text {th }}$ century, believed. 58 “The Democratic Convention” The American Whig Review, vol. 16. Issue 91. July 1852.
} 
or Douglass even! But to place beside him a mere blank. It was an insult. ${ }^{, 59}$ Botts's speech represented the tone of the campaign, which descended into attacks on manhood and character. Botts emphasized the manly attributes of Scott and discredited Pierce's manhood by comparing him unfavorably to other Democrats like Cass and Douglas. Botts's description of Pierce's nomination as an insult shows that the candidates needed to cultivate credible character just as much as they needed to promote their accomplished careers.

Throughout his speech, Botts unwittingly made references to divisions within the Whig Party that had originated in Scott's nomination. Botts claimed that Scott was his first choice for president and praised factions of the party as the "Old Henry Clay party," but acknowledged he would have supported Webster had he been the nominee. He most likely made the comment in order to show party unity, but it highlighted the discontent within the party when Scott received the nomination over Webster. Despite his advanced age, Webster still had presidential ambitions leading up to the Whig Convention. Angered over the convention's decision, Webster did not support and endorse Scott for president. Followers of Webster urged him to run as an independent candidate, but he refused. Without Webster's support, Scott's credibility, which was already in question due to his lack of experience, suffered throughout the campaign. ${ }^{60}$

Winfield Scott's acceptance letter for the nomination coincidentally hit the press on the same day as the news of Henry Clay's death. Clay lay on his deathbed during the Whig convention and passed away on June 30, eight days after the convention adjourned.

\footnotetext{
59 "Enthusiastic Whig Meeting” NYDT, October 16, 1852.

${ }^{60}$ David M. Potter, The Impending Crisis 1848-1861 (New York: Harper and Row, 1976), 235; Michael F. Holt, The Rise and Fall of the American Whig Party: Jacksonian Politics and the Onset of the Civil War (New York: Oxford University Press, 1999), 733; Peterson, The Great Triumvirate, 486.
} 
For the Whigs, remembering Clay's life evoked fond memories of the past even as it produced an ominous vision of their future. The Whigs debated possible candidates throughout the convention. With Scott, Webster, and incumbent Millard Fillmore the top three choices, Whigs struggled to unite on a party platform and candidate. Scott managed to receive the nomination, but dissent among the Whigs was apparent. On only two occasions during the six days of the convention did the factions within the party unite, and they did so to commemorate Henry Clay. Whig sentiment in the convention has left historian Michael Holt to observe that the "Whigs were far more united when they looked to the past than when they confronted the future..." ${ }^{\prime 61}$ It was only the beginning of disagreements that soon broke the party apart.

Democrats struggled to convince citizens that Pierce had the republican traits supposedly held by the previous generation. During his candidacy, Pierce's war record during the Mexican War caused great concern that he lacked the necessary qualities to gain the nation's trust. During the battle at Contreras near Mexico City, an artillery explosion knocked Pierce from his horse, and he fainted from the pain. Despite the wound, Pierce commanded his unit the next day in battle when again he twisted his knee and fainted from the pain. His men attempted to take him to safety but he instructed them to leave him where he was, humiliated that he had fainted for a second time. Pierce survived the rest of the battle and war, but never had another opportunity to achieve the military glory he craved. There was no shame in Pierce's service to the country during the war, but his misfortune in battle resurfaced during the 1852 campaign. Eulogists for the Great Triumvirate claimed the country needed a president with strong leadership and

\footnotetext{
${ }^{61}$ Holt, The Rise and Fall of the American Whig Party, 725. For more on the Whig politicians and political culture, see: Daniel Walker Howe, The Political Culture of the American Whigs (Chicago: University of Chicago, 1979).
} 
courage, and with those messages fresh in the minds of citizens, the presidential candidates appeared not to meet those desired traits.

Political cartoons used the battlefield incidents to bring up larger questions about his masculinity. These cartoons, similar to the songs and poems, go beyond the mockery of Pierce fainting during battle and charge him with not being man enough to be president and commander-in-chief. Citizens wanted a president who exhibited courage as well as statesmanship. A poem printed in the Daily Cleveland Herald lamented Pierce's unmanly characteristics and claimed, "Like a blood-hound the heart strings of manhood he tore, and with tremulous fawning a collar he wore." ${ }^{62}$ Continued tension with Mexico and Great Britain over territorial borders threatened war continuously and the faction of the Democratic Party known as Young America harbored expansionist goals. Pierce was a popular candidate to followers of this movement and needed to exemplify the manly qualities and assure the faction that he would put such policies into practice. Edmund Burke (New Hampshire congressman), a friend of Pierce, explained that "the grand ideas which are to be most potent in this election are the sympathy for the liberals in Europe, the expansion of the Republic southward and westward and the grasping of the magnificent prize of the commerce of the Pacific - in short the ideas of which the term 'Young America' is the symbol." ${ }^{63}$ Whigs were aware of Young America's appeal, and focused on Pierce's manliness and ability to be commander-in-chief to increase their chances of discrediting him. Examining campaign paraphernalia illuminates the at-times contradictory nature of the Whigs. In some instances, Whigs recoiled from democracy,

\footnotetext{
62 "For Franklin Pierce, 3" The Daily Cleveland Herald, September 9, 1856. This anti-Pierce poem attacks his manhood and character due to his stance on the slavery issue in Kansas. The Daily Cleveland Herald hereafter cited as $T D C H$.

63 "Edmund Burke to Franklin Pierce" June 14, 1852. Some Papers of Franklin Pierce, 1852-1862.
} 
but like antidemocratic eulogists, they often used democratic means available to them in the political culture. ${ }^{64}$

Whigs' attacks on Pierce's character also betrayed the party's southern strategy. Southerners were skeptical about Scott's loyalty to the South and his opinions on slavery's expansion, and his rhetoric preceding the campaign did little to convince them otherwise. In order to combat this uncertainty, Whigs hoped that confidence in Scott's manhood and courage would override southerners' fears on the slavery question. Whigs hoped that accusing Pierce of being a coward would be enough to make southern men skeptical of his character and sway southern Democratic support to Scott. Whigs understood how important concepts of manhood and honor were to Southern culture, and they openly mocked Pierce's fainting spells and his suffering from diarrhea during the Mexican campaigns. ${ }^{65}$

Democrats understood the ramifications of the Whigs' portrayal of Pierce and attempted to refute the charges and raise questions about Scott's masculinity and character. Since Pierce was relatively unknown, the biographies of him published and printed in newspapers would be influential in molding public perception. Pro-Pierce biographies focused heavily on connecting Pierce to his father, a Revolutionary War hero, to validate the candidate and lend his character credibility. Connecting him not only with his father but also with the men of the first generation would construct an emotional attachment between citizens enamored with the founders and Pierce. ${ }^{66}$ Pierce turned to his closest friend and acclaimed writer, Nathaniel Hawthorne, to write his biography.

\footnotetext{
${ }^{64}$ Amy S. Greenberg, "The Politics of Martial Manhood," www.common-place.org, Vol 9, No. 1, October 2008.

${ }^{65}$ Holt, The Rise and Fall of the American Whig Party, 731.

66 "Memoirs of the Candidates" Weekly Herald, June 12, 1852.
} 
Hawthorne attempted to reassure voters who were concerned that they knew so little of Pierce by reasoning it was due to his good and selfless character. He was a republican leader cut from the same cloth as Webster, Clay, and Calhoun. Hawthorne realized the significance of elucidating Pierce's war record, and cited several sources to validate Pierce's courage and toughness in battle. In Hawthorne's opinion, the story was not about Pierce fainting; rather it was about Pierce having the strength and courage to continue to command in spite of his severe injuries. Hawthorne even noted that Winfield Scott wanted Pierce to rest after the injuries, but Pierce insisted he stay to lead and fight with his unit. ${ }^{67}$

Hawthorne's attempt to enhance Pierce's manliness and credibility as a candidate became an example of the demagogic nature of the Democratic Party. Whig newspapers condemned the work. The Boston Times' editor declared that only "the author, the proofreader, and the hero" read the biography. He went on to say of Pierce's career: "What a farce this life is - especially the political part of it!"68 The New York Times announced that it was time to expose the real Franklin Pierce: an average student, lackluster attorney, unsuccessful soldier, boring speaker, and doughfaced politician. ${ }^{69}$ To many, the biography was another example of the ways in which the Democrats fabricated Pierce's qualifications to justify his nomination. The North American and United States Gazette stated, "When it is considered that, six months ago, the man who now occupies the prominent position of a candidate for the highest place in this government was almost totally unknown, and that his name, even, was, for weeks after his nomination, a

\footnotetext{
${ }_{67}^{67}$ Nathaniel Hawthorne, Life of Franklin Pierce (Boston: Tickner, Reed, and Fields, 1852), 97.

68 "Chas. C. Hazewell, editor of the Boston Times, in one of his 'Alogoma' letters to the New York Herald, writes as follows about Hawthorne's 'Life of Franklin Pierce'” New Hampshire Statesman, July 16, 1853.

${ }^{69}$ Brenda Wineapple, Hawthorne: A Life (New York: Random House, 2003), 265.
} 
philosophical mystery which puzzled the country.” The Gazette went on to charge that "Paritzan [sic] partiality did all it could do to place Mr. Pierce in the high road to martial glory.",70 The Cleveland Herald ridiculed another Ohio "Locofoco" paper that attempted to advance Pierce's military stature and mistakenly claimed that Pierce fought in the War of 1812 Battle of York. The author for the Herald concluded that, "There is some need of embellishments, to make a great hero of Mr. Pierce. ${ }^{, 11}$ In reaction to mounting criticisms over Pierce's nomination, the Democrats went on the offensive and filed similar accusations against Scott. Both parties played upon emotions of voters and issues like masculinity that deflected attention from slavery's role in democratic political culture.

Democrats mirrored tactics used by the Whigs to attack Scott and his ability to be president. Scott had a decorated war record, but it did not leave him protected from assaults on his personal character and manhood. Similar to the Whig cartoons, proDemocrat cartoons assailed Scott as an elitist unfit for the presidency. Democrats capitalized on Scott's disparaging nickname "Old Fuss and Feathers" which derived from his pretentious and snobbish attitude. While on the surface these attacks appear to be focusing on class rather than gender, the Democrats used Scott's personality to show that he was not a "martial man" despite his military career. A cartoon called "A Bad Egg. Fuss and Feathers" depicts Scott as a fighting cock with human attributes. Like Whig cartoons that used a cock in order to signify Scott's manhood and disparage Pierce's, Democrats also used the animal in their attacks on Scott's masculinity, questioning his ability to think independently and avoid being corrupted by more influential men of the party. The cock is wearing a plumed hat, dress sword, and fringed military epaulettes in

\footnotetext{
70 "Franklin Pierce's Biography” North American and United States Gazette, September 8, 1852.

71 "Franklin Pierce, the Hero of York! - The Statesman Outdone" TDCH, June 11, 1852.
} 
order mock Scott and his love for elaborate military attire. The cartoon shows a cracked egg saying "Free Soil Egg hatched at Baltimore June 21 ${ }^{\text {st }} 1852$ " [the day of Scott's nomination]. The cock then crows: “Cock a doodle doo! I'm Bill Seward’s Cock!!! Whose Cock are you?" The cartoon charged that Scott was just a political tool of powerful New York Whig William Seward, and that he used Scott to promote the Free Soil agenda. This charge was significant since many southerners were still angered by the aftermath of the 1848 election, in which southern Whig Zachary Taylor betrayed the region's interests by acting as a shill for Seward. Additionally, the cartoon played to public fears that Scott was out of touch with common Americans, reinforced by his Fuss and Feathers nickname. The type of rough humor depicted in cartoons was calculated to influence men who enjoyed ribald jokes. Much of eulogists' concern surrounded that rough class of men, who they feared did not have the republican virtue to make wise decisions and would fall prey to the manipulations of political parties. Sermons and eulogies, while available for anyone literate, nonetheless were pitched to an educated and upper class audience. ${ }^{72}$

Orations for the Great Triumvirate in 1852 did not ignore the presidential election. With Webster dying just weeks before citizens went to the poll to cast their votes, the public compared the condition of politics past and present. New England Reverend Nehemiah Adams noted the apparent hand of God in Webster's death on the eve of the presidential election. "We cannot doubt that the removal of our distinguished fellow citizen, just at this time, will have an important influence, but we know not how, upon the event of the coming election," he stated to his parish. He referenced the desire to have Webster be the Whig nominee, while avoiding using the actual name of the party,

\footnotetext{
72 “A Bad Egg. Fuss and Feathers” (New York: published by Nathaniel Currier, c1852).
} 
and questioned what could be learned from Webster's death so close to the election. ${ }^{73} \mathrm{He}$ spoke directly to Whig supporters and stated, "I speak to you who are members of that party, not as a politician, but as a believer in God's providence, and ask you to see the hand of God in your affairs," while acknowledging the message that God sent through Webster's passing. ${ }^{74}$

The death of Clay and Webster amid the 1852 election magnified the loss of Great Triumvirate to Americans. Eulogists in particular noticed a transitional moment from the nation's second political generation to the third after Webster's death. To deal with a political culture that appeared in decay, eulogists preferred to stick to nostalgic memories of the past. Reverend G.W. Samson noted that shift with Webster's death so close to the presidential election, lamenting that with his death the nation lost "the last and greatest of the second generation of our nation's leaders." ${ }^{, 75}$ He talked about the importance of the political generational shift, and discussed how Webster, Clay, and Calhoun fit with the other leaders in the nation's past. According to Samson, they were the leaders of the generation that was critical to the young nation's survival. It was time for a new generation to prove themselves worthy of maintaining their inherited republic. "And now the second era of our national history is past; the second generation of our great statesmen, Adams, Calhoun, Clay, Webster, have all gone," Samson noted. He continued to ask, "and now, when great crises shall arise, who will stand in the place of our Webster?"76 Samson saw the timing of Webster's death as a sign from God and believed that Providence seemed to break up the political parties just as "great leaders" passed

\footnotetext{
${ }^{73}$ Adams, A Sermon Preached to the Congregation at the Essex Street Church, 11-12.

${ }^{74}$ Ibid., 13.

${ }^{75}$ Samson, The Providence of God in Raising up under our Republican Institutions, Great and Good Men as our Rulers, 5.

${ }^{76}$ Ibid., 14.
} 
away. Samson understood the importance of individual leaders to the public and parties that needed them. "Surely God means that we should think more of having good men than a great party," and urged his congregation to look to God to "raise up such men" as he concluded his sermon. The sermons and eulogies delivered for Webster, and for the Great Triumvirate, indicate the cultural importance of the memories formed. While Pierce and Scott received criticism for being frauds and partisans, Webster, Clay, and Calhoun also received their fair share of criticism during their careers. Eulogists, however, largely cleansed their reputations after Webster's death, and those nostalgic memories reflected the longstanding concern with democracy, and influenced perceptions of politicians like Pierce. ${ }^{77}$

It came as no coincidence that the Democrats won the election in 1852 on the heels of Webster's and Clay's deaths. Webster's tenuous relationship with the Whigs before his death seemed to foreshadow the impending dissolution of the party, which desperately needed national statesmen like Webster and Clay in order to remain a viable anti-Democrat coalition. ${ }^{78}$ Pastor R.H. Richardson believed that their deaths had significant ramifications on the future of the nation's political system. He questioned

\footnotetext{
${ }^{77}$ Ibid., 16.

${ }^{78}$ Election Day came and went without the enthusiasm seen in previous elections. Despite the recent influx of immigrant voters, turnout rates fell to the lowest level since 1836, a decline not equaled again during the nineteenth century. Pierce won the election soundly in the Electoral College; however, the numbers are misleading. His margin of victory was extremely narrow even though Scott only won four states. In the popular vote, Scott received 1,386,580, Pierce 1,601,474, and one-time Democrat and former close friend to Pierce, John P. Hale, received 156,667 votes as the Free Soil candidate. Additionally, the deceased Daniel Webster got 7,000 votes. With more than three million votes cast in the election, Pierce only had about fifty thousand more votes than did his combined opponents. The small margin of victory over his opponents shows the increasing frustration with the Democratic Party and its new candidates. It also more broadly demonstrated the continued frustration with democratic culture and the willingness to vote for alternative parties during the antebellum era. See: Larry Garra, The Presidency of Franklin Pierce (Lawrence: University of Kansas Press, 1991), 39; Potter, Impending Crisis, 231. Potter notes that many historians refer to the election of 1852 as being the last of the bisectional party organization. It is indisputable that Pierce did win the election bisectionally, but Potter argues that the era of truly bisectional parties had already passed by 1852 .
} 
whether the Whigs, although not mentioning the party by name, would dissolve without Clay and Webster. "Was it a mere coincidence," he asked, "that the greatest defeat known in the history of political warfare in this country, should tread upon the heels of that victory which the last Enemy had won, over the two most prominent men of the defeated party?" Though not specifically naming the parties of which he spoke, Richardson's sermon was quite political. He believed it was more than a coincidence that "the Providence which ordered such a sequence of events, designed to indicate the opening of a new era in the political history of the land." ${ }^{, 79}$ The loss of Clay and Webster signaled the demise of the party, which throughout its tenure lacked coherent party loyalty. Without Clay and Webster, two champions against the Democratic Party, the tenuous Whig Party loyalty continued to erode.

The remembrance of the Great Triumvirate and its achievements raised anxieties and criticisms at home and abroad about whether truly great statesmen could rise above democratic culture and obtain the country's highest political position, the presidency. Webster, Clay, and Calhoun all had presidential ambitions; however, all failed to win the presidency and even their party's nomination on several occasions. The London Times used their failures to reach the presidency as an indication that "no great man can ever be elected to that high office." That opinion resonated throughout the United States, but also received repudiation. The Journal of Commerce argued, "The appearance of three such minds on the public stage, at the same moment, is unprecedented in the history of modern nations. They were giants, but they were equals." It surmised that intelligence was the reason behind them not becoming president, and implied that they served as a check and a balance to one another throughout their careers. "It thus happened that each was

${ }^{79}$ Ibid., 17. 
opposed by both the others, and there was ever a preponderance of great men on the side of opposition. There were two opposing one, and the majority were successful." As this article came out just months before Webster's death, the Journal concluded, "he will pass from life to history, on the same footing with his illustrious compeers, one of the few, the immortal names, that were not born to die. ${ }^{, 80}$ The New York Times refuted the positions of both the London Times and the Journal of Commerce. "Their honors were greater, their reward nobler. If they craved the less valuable, but more substantial, pay of political station, it was a departure from their mission, a sacrifice of a half-divinity, for the lower indulgences and appetites of mere humanity." ${ }^{\prime 81}$ The praise of the supposed sacrifice of the Great Triumvirate kept concerns permeating in public psyche about democracy's ability to produce great men and enable them to obtain the presidency.

How European nations viewed America's republic was important to many citizens. The merits of democracy increasingly were under scrutiny throughout Europe. Criticism from abroad also initiated self-reflection about American institutions and politicians. The New York Herald discussed how the world judged the United States on its political leaders. "In the days of Clay, Webster, Calhoun, and their compeers, the statesmen of America were such as any nation might have been proud of," the paper exclaimed. The paper understood the importance of political generations, and it discussed such esteem for the Founding generation. The Herald lamented the current generation of politicians however, thus also condemning the political culture in which they rose to power. "Now, we can hardly point to a single politician of whom one can bear to speak with anything like patience," the Herald bemoaned, continuing to state that besides a few

\footnotetext{
80 "Presidential Candidates" Littell's Living Age, September, 4, 1852.

81 "Not Title" NYDT, August 11, 1852.
} 
exceptions, the current politicians were "unprincipled, reckless, brutal, corrupt, and many of them imbecile and ignorant besides." It asked its readers, "are there no decent men in the country to choose for political office?" For eulogists, the culture democracy fostered left that question in doubt.

Frustration with "available" presidential candidates caused citizens to look back longingly on the nation's republican roots. A.D. Mayo bemoaned the quality of past presidents, yet lessened the importance of the position of the presidency to government operations. "We will not complain that the last six Presidents have been men of second rate ability, while Clay, Calhoun, and Seward were in the Senate, Adams in the House, and Corwin and Webster in the Departments," he uttered to his congregation during his sermon after Webster's death. ${ }^{82}$ With such republican leaders in prominent positions of government, it lessened the importance of the man in the presidency. Indeed, Mayo seemed to also lament the Whigs' inability to obtain the presidency. Yet, by mentioning Calhoun, who was not associated with any national party, displayed how his connection with Clay and Webster altered how northerners viewed his legacy. Independently, Calhoun was a southern rights champion, which many northern Whigs detested. However, after his death his association with Webster and Clay elevated him to national renown as the three remained linked and allowed for all sections to praise them, despite their differences, as "great men." Pierce and Scott had to contend with not only the long careers of Webster, Clay, and Calhoun, but also with crafted nostalgic memories of the deceased politicians who no longer had to defend their past controversial opinions. Opposition parties no longer saw the political gain in attacking the Great Triumvirate,

\footnotetext{
${ }^{82}$ Mayo, A Sermon on Daniel Webster, 13.
} 
and used chosen parts of their careers to attach with particular positions and policies that could benefit the political struggles of the day.

The regional balance of Webster, Clay, and Calhoun in Congress helped solidify idealistic memories throughout the country. The Arkansas Whig commended Massachusetts and South Carolina for coming together to honor Daniel Webster. The paper re-printed the legislative committee of Massachusetts' response to the public meeting held in Charleston, South Carolina after Webster's death. The legislature included Henry Clay, who they claimed "completed the triumvirate" with Calhoun and Webster, and praised the three for their nonpartisan devotion to the nation. To show respect for Calhoun, the Massachusetts legislature stated: "No where was the intellectual power and self-sacrificing patriotism of Calhoun better acknowledged than by our own commonwealth.. ${ }^{, 3}$ While Calhoun's position on slavery and states' rights repulsed many Massachusetts residents, his connection with Webster and Clay allowed for all parts of the nation to speak of him as a man of principle who worked with his peers to strengthen the burgeoning nation.

Webster's association with Clay and Calhoun allowed southerners to admire Webster's legacy, despite his often-critical stance against the southern rights position. The Charleston Mercury, a radical southern rights paper, praised Webster's career. The paper lamented the current state of national politics and reminisced about the Great Triumvirate. In remembrance of their native son John Calhoun, the paper exclaimed that, "he also had to sustain him the judgments of his great rivals and antipodes in theory and practice-Webster and Clay." The paper continued, "These statesmen were unlike Calhoun in this: they were federal, but they were like him in their devotion to our

83 "South Carolina, Massachusetts" Arkansas Whig, July 7, 1853. 
government. ${ }^{\text {84 }}$ After Webster's death, the Charleston Mercury highlighted the differences among the three men, while looking back nostalgically at their last time in Congress together. The newspaper highlighted the spectacle of their power as well as praising their careers during the crisis of 1850 , arguing, "it was their last and greatest gladiatorial scene, and the spectators can scarcely hope to look upon its like again in this generation." The paper continued to observe the differences in style among the three men, yet praised each for their individual greatness. ${ }^{85}$ Lionizing the three gave credence to South Carolina's long struggle to protect slavery under the guise of states' rights. By praising Webster's legacy, southerners subsequently disassociated the southern position from being an extremist movement. Additionally, recognizing Webster's connection with Calhoun elevated Calhoun from a sectional extremist to a national politician on an equal level to Clay and Webster. The Raleigh Register, for example, used the Great Triumvirate to delegitimize northern abolitionists. The paper attacked northerners who denounced "such men as Webster, Clay, Calhoun and all Southern Statesmen." Associating the Great Triumvirate with respective opinions on sectional beliefs illuminates the power of the eulogy in antebellum America. Eulogists not only determined who "great men" were, but they also identified who the politicians unworthy of high esteem were. The relationship among the three allowed southerners to speak highly of Webster and condemn other northern politicians who did not subscribe to the southern rights political platform. The regional balance that eulogists emphasized about the three furthered the notion that a new generation of politicians could not achieve such a standing due to present sectional division and political fracturing.

\footnotetext{
84 "Charleston Mercury - Messrs. Hammond and Stephens" The Charleston Mercury, September 06, 1859.

85 "From the Charleston Mercury. CALHOUN, CLAY, WEBSTER" Liberator, November 26, 1852.
} 
Former Charleston Courier editor Richard Yeadon looked to rosy interpretations of the past while delivering an oration before the "Society of " 76 " and "Fourth of July Society." He told his southern audience that Webster, Clay, and Calhoun formed the most "lustrous and most remarkable constellation of human greatness and excellence- $\mathrm{a}$ cluster of the brightest stars that ever culminated at the same time and on the same meridian." He declared that they lived "only to serve and bless their country," when praising their devotion while also admiring the generation from which they came. As with orations in the northern and middle states, southerners praised the three men together and placed them as equals in terms of national prestige. Like other orators, he spoke about each man individually in order to pay respect to each region of the country. In addition, even though each was beloved in his particular region, Yeadon exclaimed, "each was regarded as the common property of the nation." Addressing them as a triumvirate, and not only individually, illuminated the desire of all regions to look back longingly at the nation's republican roots through a sectional lens. Eulogists sought a vision of a united nation on sectional terms. It also reminded citizens that there were politicians in the past from other regions of the nation who did supposedly put the nation above section. During the hostile 1850s, reminders that there were trusted statesmen from other regions solidified the idealistic memories of the past, but also heightened already existent anxieties about whether future politicians would garner that trust and respect. ${ }^{86}$

Soon after the news of Webster's death traveled across the country, an outpouring of public sentiment called for official commemorations of mourning to pay respect to the Great Triumvirate. As sermons, eulogies, and newspapers conveyed the nation's grief, other calls for monuments and funerals quickly surfaced as citizens sought to pay respect

86 “Clay, Webster, Calhoun” Fayetteville Observer, July 28, 1853. 
to the men. The Times Picayune published an extra issue upon receiving a telegraph of Webster's passing. The paper also included a message issued by the city's mayor, Abdiel Crossman. In his message to the people of New Orleans, Crossman noted the importance of all three to the nation. "Afflicted people, the last has been gathered to the tomb of his fathers," he told the resident of New Orleans. He stressed that although Webster was from Massachusetts, he was emphatically a national man. ${ }^{87}$

The people of New Orleans believed that Webster's passing provided an opportunity to honor not just Webster, but also Clay and Calhoun. Residents of New Orleans began preparations for an official commemoration for Webster, Clay, and Calhoun. On December 9, 1852, New Orleans held an extravagant funeral ceremony. After the event, the city published a detailed account of the organization and proceedings that occurred. The publication noted the mood of the city's residents, stating:

It struck the general mind, that a ceremony uniting the feelings entertained by the entire community towards the departed Triumvirate, would be impressed with a more imposing solemnity, commensurate with the history of the deceased as a trio in the nation's councils, than a funeral display designed to honor the memory of only one of them. The latter would be sectional; the former, national.

The public commemoration became one of national significance and attention as the funeral planned to honor the achievements of the three statesmen and what they meant to the nation. ${ }^{88}$

New Orleans residents brought the legacy of the Great Triumvirate into the public sphere not just to lament their absence, but also to use them to display their desires and concerns about democracy. Ordinary citizens always had participated in mourning rituals

\footnotetext{
${ }^{87}$ A History of the Proceedings in the City of New Orleans on the Occasion of the Funeral Ceremonies in honor of Calhoun, Clay and Webster, Which Took Place on Thursday, December $9^{\text {th }}, 1852$. Published by order of the General Committee of Arrangements, on the Authority of the City Council (New Orleans: office of the Picayune, 1853), 7.

${ }^{88}$ Ibid., 11,15 .
} 
for national leaders. The public funeral highlighted the types of men whom democracy had produced; it also illuminated the fears held by citizens regarding the future of democracy to produce men similar to the Great Triumvirate's caliber. "The thought, unexpressed, and perhaps not clearly defined, produced a profound impression upon most minds, that with the death of the Illustrious Triumvirate, whose memory these obsequies were designed to honor, a great gulf has been opened between the present and the past of the country," detailed the publication printed of the ceremony. Commemorations of the three men together reinforced the cultural notion they were a "great triumvirate." 89

The funeral ceremony began on the sunny December afternoon just as the breeze cleared away rain clouds from the previous evening. Businesses shut down and thousands came to witness the funeral. The funeral procession consisted of five "grand divisions" as it went through the streets of New Orleans. Six gray horses pulled a funeral car, which was the principal feature of the procession. The 11-foot long and 16-foot high car had the bed covered in black velvet, and was adorned with silver trimmings. On the car stood three bronzed urns, each bearing the name of one of the members of the Great Triumvirate. The car also had Calhoun, Clay, and Webster in large silver letters on the broad draperies. Black velvet covered the six horses pulling the car, studded with silver stars, and stamped shields containing the arms of South Carolina, Kentucky, and Massachusetts [Figure 1]. Thirty-one pallbearers, intended to represent each state in the Union, marched in single file next to the car. Serving as chief mourners, delegates of four from the states of South Carolina, Kentucky, and Massachusetts followed the car. In addition, civilians from each respective state of Webster, Clay, and Calhoun had displays with them in the procession to honor their deceased politician and their home states,

\footnotetext{
${ }^{89}$ Ibid., 4.
} 
allowing for individual mourning in addition to mourning for the three men as one faction. The procession continued with dozens of groups, clubs, militias, and societies. It took one hour and forty minutes to pass any one particular point, and its length with participants in the procession stretched over one mile and a half. From the time it departed and returned to Lafayette Square, the procession took two and one half hours. Once the ceremony concluded, eulogies were delivered in honor of each member of the Great Triumvirate. $^{90}$

By figuratively bringing representatives and displays for the funeral procession into a public space like Lafayette Square where celebrations and gatherings often occurred, the people of New Orleans connected not just with Webster, Clay, and Calhoun, but also with the system of government that produced them. This demonstration of what historian Mary Ryan calls "meeting-place democracy" pervaded the city as its residents paid tribute to three men whom their fellow citizens deemed exemplars of the Union. ${ }^{91}$ The money and planning for the public commemoration indicated the importance of public commemorations, in particular for political leaders, as this example shows. In the aftermath of the 1852 election, the people of New Orleans, along with the rest of the nation, sought ways to remember a past generation of politicians who seemed

\footnotetext{
${ }^{90}$ For the order and listing of individuals and groups in the funeral procession, see pages 24-27 in A History of the Proceedings in the City of New Orleans on the Occasion of the Funeral Ceremonies in honor of Calhoun, Clay and Webster, which has already been cited. For a detailed account of the funeral car and public displays by the civilians from South Carolina, Kentucky, and Massachusetts, see pages 33-36. For information on the length of the funeral procession, see page 38. Louisiana Chief Justice George Eustis, Theodore McCaleb, and Christian Roselius delivered the eulogies on John C. Calhoun, Henry Clay, and Daniel Webster, respectively.

91 "New-Orleans: Correspondence of the New-York Daily Times" NYDT, December 10, 1852; "The Funeral Honors to Webster, Calhoun, and Clay, at New-Orleans" NYDT, December 7, 1852; Mary P. Ryan, Civic Wars: Democracy and Public Life in the American City during the Nineteenth Century (Berkeley: University of California Press, 1997). Mary Ryan examines civic wars in New Orleans, New York, and San Francisco to show how a divided public using a shared space defined democracy in the antebellum. Ryan argues that the "meeting-place democracy" in cities began to deteriorate by 1850 and foreshadowed the Civil War.
} 
to have the republican traits of the founding generation. Public funerals, sermons, eulogies, and displays of mourning created nostalgic memories of previous politiciansthey made them "great men"-in order to cope with the concerns over the current state of democracy. Noting the concern about who would fill the void now left, the New Orleans publication of the proceedings bemoaned, "we do not know who is to be the CALHOUN, the CLAY, or the WEBSTER of the time that we feel to be coming, when we know that we shall need them." By 1852 , the nation, already apprehensive of the possibility of disunion, realized that men such as Calhoun, Clay, and Webster no longer were available to soothe sectional fears and find compromise; whether or not any national statesmen could fill that void remained a matter of public uncertainty. ${ }^{92}$

The public commemoration in New Orleans for the Great Triumvirate reinforces the notion that a nonpartisan impulse still permeated the political culture in the 1850s. The funeral and public displays of mourning illuminate that while citizens lamented the magnitude of the loss of the second generation and what it meant for the future of American politics, they simultaneously used the mournful commemoration to celebrate and reconnect with the nation's republican past. That past included the dangers of partisan politics, which still lingered as citizens in both the North and South remembered national politicians after their deaths.

With neither Webster, Clay, or Calhoun aligned with the Democratic Party, and New Orleans having a Whig mayor and strong Whig support, it raises the question of whether the public funeral was merely an act of partisan politics. The publication for the proceedings held the opinion that the funeral served as both a lesson to future generations

\footnotetext{
${ }^{92}$ A History of the Proceedings in the City of New Orleans on the Occasion of the Funeral Ceremonies in honor of Calhoun, Clay and Webster, 5.
} 
and for current politicians regardless of political affiliation. Regarding the memory of the Great Triumvirate, it stated that "not only will many an obscure youth find stimulants to perseverance in the path of public duty," but that living statesmen "in the heat of conflict, may find in them the consoling assurance of a just appreciation, when they, too, shall have emerged into an atmosphere cleared of the partisan mists of the day." Citizens in the 1850s still found discomfort in partisan politics and looked back longingly to an era of men who, they perceived, put the good of the nation above parties or sections. In addition, Democrats also took part in the commemoration. After the news of Webster's death, the Louisiana Democratic State Central Committee published a resolution stating that the committee, "most heartily proffer to the Mayor of New Orleans, its cooperation in any measures which the city may deem proper to take in honor of the illustrious dead. ${ }^{93}$ Beyond offering support for a commemoration, the Democratic committee also participated as its members walked with the Whig State Committee in the funeral procession. Democratic governor Joseph Walker took part in the procession, along with other Democrats of various professions and associations. ${ }^{94}$ Memorializations offered temporary reprieve from partisan democracy. Politicians united around party lines for the sake of commemoration. Political organizations remained cognizant of the public's distrust of political parties and reacted by attempting to appear nonpartisan and defenders of that cherished republican past.

Attempts to memorialize the Great Triumvirate went beyond ceremonies, as some argued for the erection of monuments in its honor. In calling for a marble monument, the Journal of Commerce exclaimed, "These funeral processions in honor of the illustrious

\footnotetext{
${ }^{93}$ Ibid., 9.

${ }^{94}$ Ibid., 24-25
} 
dead signify but little, except for the wonder of the day. The expense, if contributed to some object of this kind, would do more to attract the attention of posterity." Monuments for revered politicians were not unique to the time. A monument commemorating George Washington was still in construction in Washington D.C., and many urged the creation of one for Andrew Jackson. The call for a monument for the Great Triumvirate was unique in that its members would be included together on one monument, signifying their connection to one another. The hope for a monument, along with joint funerals, highlighted the ways in which the country venerated these men to prove the righteousness of a republican government and that it could produce statesmen similar to the founding generation. The public praised each man's individual attributes, but taken together, the nostalgic memories of the Great Triumvirate embodied the concern that the country had for the nation's government and for its future. Erecting a monument in public space would not just remind Americans of the Great Triumvirate during the present, but would remind future generations of the great men their republic had generated. It would also offer an example of the republican traits needed out of its citizens and future politicians. ${ }^{95}$

Franklin Pierce's presidency served as a reminder to citizens of the delicacy of their republic and the need for manly national statesmen to direct it. Public mistrust and anger against Pierce and his administration culminated in 1854 over slavery in the western territories. The long-standing Compromise of 1820 that Henry Clay helped to

\footnotetext{
95 "Monuments in Marble" NYDT, October 30, 1852. Members of Congress sent a petition to the National Intelligencer in support of a monument for Henry Clay. Monument associations dedicated to memorializing Clay arose after his death, and nationally there was a call for a monument to honor Clay and his services to the nation. The open letter to the editor stresses the desire not to overshadow local memorials for Clay. However, it argued for an additional national monument for Clay where future generations could make "patriot pilgrims" to his grave and monument. It also noted that while Kentuckians looked to its sister states for financial support, it made note that it would also second a movement for a monument to Calhoun in South Carolina and to Webster in New England. See: "Proposed Monument to Mr. Clay" Daily National Intelligencer, December 24, 1852.
} 
broker supposedly put the issue of the expansion of slavery to rest. When the slavery issue once again appeared in Congress in 1850, Clay came out of political retirement and despite his age and frail health served as a nonpartisan negotiator with the help of Daniel Webster. ${ }^{96}$ By 1854, Stephen A. Douglas—-who championed his help with the Compromise of 1850 - had brought up the idea of popular sovereignty for determining the legality of slavery in territories. As chairman of the Senate Committee on the Territories, Douglas had been working on a bill that sought to create the Nebraska and Kansas territories and open them up for settlement. He assuredly had personal reasons for the bill, as it was initially a way for him to gain support for a Pacific railroad. He likely also had ambitions to run for president in the next election. Key southern politicians demanded that the bill officially retract the Missouri Compromise if it were to gain southern support. The proposed bill ultimately repealed the Missouri Compromise and installed the idea of popular sovereignty. In theory, popular sovereignty was a triumph of democratic thought. It put the power in the hands of citizens to determine their laws and policies. However, the public viewed it as a subversion of the almost sacred compromise of "great men," and particularly Henry Clay, in $1820 .{ }^{97}$

A firestorm of criticism quickly engulfed Pierce and other supporters of the bill. The public watched politicians and political factions resort to fraud and deception to get it passed, putting their personal ambitions ahead of the country and repealing compromises that the second generation had passed in order to avoid disunion. "It is the determined purpose of the Administration to uphold the Territorial laws of Kansas, - and thus crush

\footnotetext{
${ }^{96}$ For more on Clay's legacy, particular with the compromise of 1850, see: Sarah Bischoff Paulus, "America's Long Eulogy for Compromise: Henry Clay and American Politics, 1854-1858," The Journal of the Civil War Era 4, 1, (March 2014): 28-30. Paulus discusses how Clay's efforts for compromise enshrined compromise as an essential tradition in the Union.

${ }^{97}$ Potter, Impending Crisis 167-170.
} 
out all freedom of speech and of the press, which would interfere with the establishment of slavery and the ultimate admission of Kansas as a slave state," claimed the New York Times. The Chicago Daily Tribune lamented, "It is another of the successive steps of outrage and fraud by which Franklin Pierce seeks to make Kansas a slave state, to put the Free State men in a false position before the World, and to make himself president of the United States for another term." ${ }^{.98}$ The Tribune highlighted the mounting aggravation over the humbugging politics that had taken over Washington. Northerners and southerners increasingly came to understand the current political style of their opponents in terms that P.T. Barnum used in his American Museum. Public use of expressions like humbug, hoax, deception, and fraud, displayed the mistrust and skepticism that Americans had with the direction their republic was heading. Many viewed the policies attempted and enacted during Pierce's presidency as hiding darker purposes that imperiled freedom and the Union. ${ }^{99}$ Pierce and Douglas took the brunt of the criticism as public outrage became more shrill. Many were skeptical about Pierce's relationship with southerners and believed he was an instrument of the Slave Power. While the public viewed Webster's association with slaveholders such as Clay and Calhoun as statesmanlike, citizens considered Pierce a pawn in the design of slaveholders.

Americans used their voting power to elect politicians who spoke out against Pierce and the Nebraska bill. The emergence and election of anti-Douglas and antiNebraska Democrat Lyman Trumbull as a Senator in Illinois following the Kansas-

\footnotetext{
98 "Border Ruffianism: The New Kansas Outrage by the president" Chicago Daily Tribune, February 19, 1856.

${ }^{99}$ Michael A. Morrison, Slavery and the American West: The Eclipse of Manifest Destiny and the Coming of the Civil War (Chapel Hill: University of North Carolina Press, 1997); For more on P.T. Barnum and his museum in popular culture, see: Bluford Adams, E Pluribus Barnum: The Great Showman and the Making of U.S. Popular Culture (Minneapolis, University of Minnesota Press, 1997).
} 
Nebraska Act indicated the strong opposition to the bill among northern Democrats. ${ }^{100}$ In a speech against Kansas-Nebraska, Trumbull reminisced about the Compromise of 1850 . He noted that both parties agreed to abide by the compromise. "Who interfered to disturb this peaceful condition of things? Was there anybody ready to interfere and violate this treaty which had been agreed upon by both parties?" he asked. "Somebody did it." The answer for him and most in the country was Franklin Pierce; the man who ran in 1852 on a pro-Compromise platform, yet by 1854 had conceded those principles to the increasingly influential Slave Power.

Abraham Lincoln, frustrated with the apparent fraud and deception used by the politicians to repeal the Missouri Compromise, re-emerged on the political stage as a member of the Republican Party. The well-publicized Lincoln-Douglas debates in 1858 highlight the public dissatisfaction with current politics, along with the prolonged connection with the Great Triumvirate. Both Lincoln and Douglas professed themselves ideological descendants of Henry Clay. Douglas attempted to silence mounting criticism from former Whigs by confronting their concerns: "Negro Equality, Amalgamation, the Great Principle of the Nebraska Bill, and signs for the lost merits of Henry Clay." Like Douglas, Lincoln used the memory of Henry Clay to promote his candidacy and to explain the history and reasoning behind his beliefs. "My beau ideal of a statesman, the man for whom I fought all my humble life," declared Lincoln in order to show his similarities and attachment to Clay. Throughout the debates, he not only referenced Clay,

\footnotetext{
${ }^{100}$ John Niven, ed. The Salmon P. Chase Papers Volume II: Correspondence 1823-1857 (Kent: Kent State University Press, 1994), 402.
} 
but also read from his speeches to remind the audience of Clay's opinions on pertinent issues of the time. ${ }^{101}$

Americans felt a sense of betrayal by their national politicians in the mid $1850 \mathrm{~s}$, a betrayal for which they had been prepared by eulogists since the passing of William Henry Harrison. Cultural representations of politics like political cartoons and poems indicated that the public shared some of the concerns of the eulogizing class, especially amid the Election of 1852. Franklin Pierce's presidency highlighted an era that eulogists had long warned against — an era of mistrust, deception, and a lack of republican virtue within those given immense political power. The memory of the Great Triumvirate united citizens over a lasting recollection of the wonders that American democracy could produce, and after the death of the Triumvirate members, the idealistic memories of their careers showed how quickly that could fade away in a degraded political culture. The memories formed after the deaths of Webster, Clay, and Calhoun had significant ramifications for American politics in the $1850 \mathrm{~s}$, as the eulogies also called men like Pierce to account and tried to convince current leaders to uphold the values of the past. The memories crafted by eulogists pervaded Americans' perceptions of the contentious events that ruptured the political system and eventually the Union. "Unknowing of the future, we should be grateful for the past," Reverend R.H Richardson stated as he concluded his Thanksgiving sermon after Webster's death. Indeed, in 1852 the nation knew little of what was to become of their republic that the Founding Fathers established,

\footnotetext{
${ }^{101}$ Allen C. Guelzo, Lincoln and Douglas: The Debates that Defined America (New York: Simon and Schuster, 2008), 109. For more on the importance of Clay's legacy of compromise on the Lincoln-Douglas debates and more broadly on politics in the years after his death, see: Paulus, "America's Long Eulogy for Compromise," The Journal of the Civil War Era, 46.
} 
and clung to nostalgic memories of how the past generation of republican statesmen managed to preserve it. ${ }^{102}$

The cultural act of eulogy was a tool used in efforts to reshape democratic political culture. Examination of eulogies for national leaders upon their death highlights the paradox of many eulogists' intentions - antidemocratic politics in democratic guise. Eulogists reminisced about manly statesmen of a republican past to warn about demagoguery and partisanship, yet they at times became demagogues themselves during their orations as they praised Webster, Clay, and Calhoun. Slavery's inextricable link to democracy was apparent in the memories of the Triumvirate's political careers. Slavery made democracy dangerous, and it appeared to endanger the Union. During the secession crisis of 1860-1861, southern eulogists warned their congregants that democracy threatened their society and secession was the way to preserve it. Northern eulogists still shared many antidemocratic beliefs, but reluctantly embraced democracy as a way to secure the immediate safety of the republic during the secession crisis.

\footnotetext{
${ }^{102}$ Richardson, National Bereavements, 19.
} 


\section{Appendix}
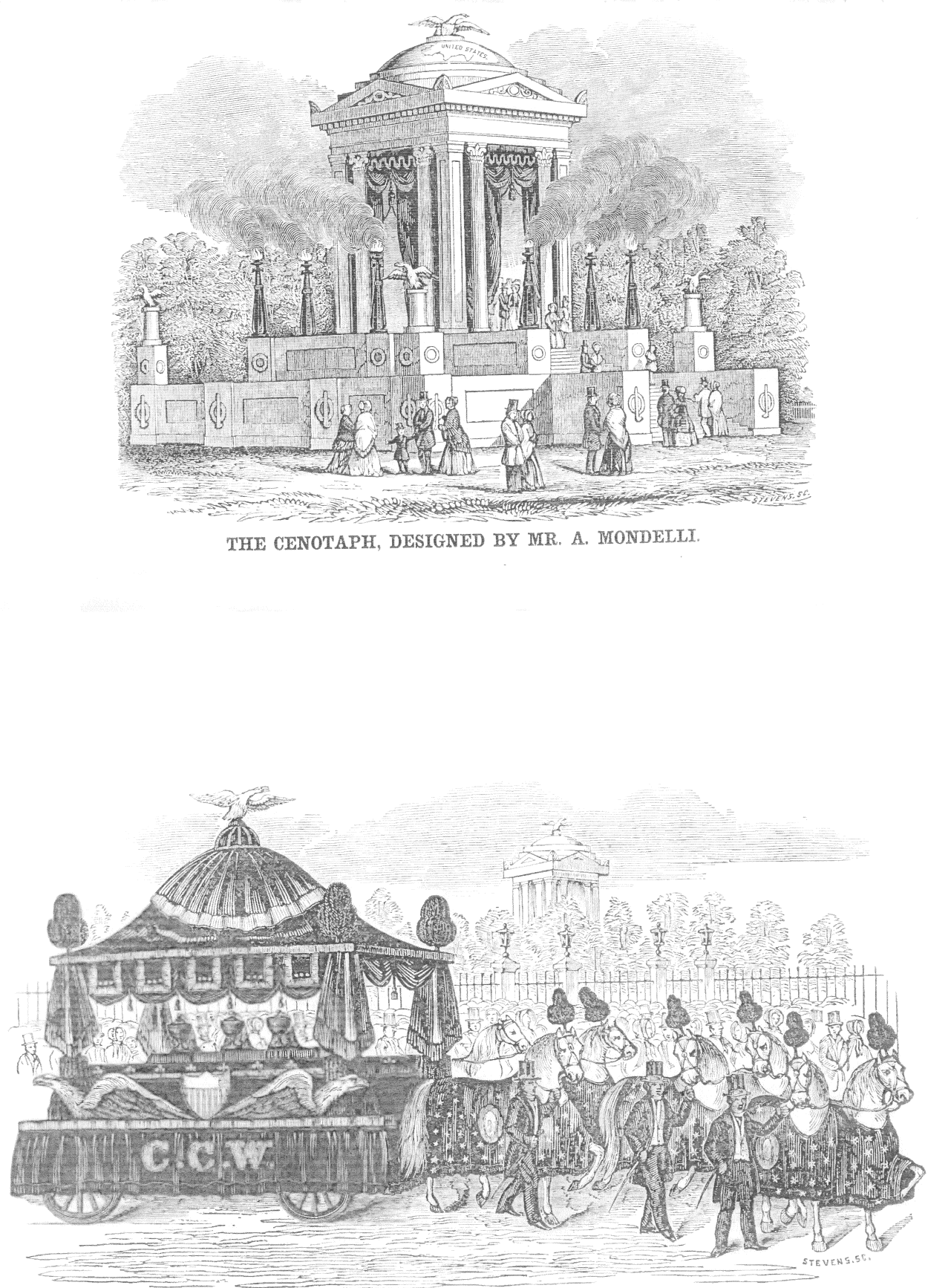

THE FUNERAL CAR, DESIGNED AND EXECUTED BY MR. DUBUUQUE. 


\section{Chapter 5:}

\section{"The Blind See It, and the Deaf Hear It": Sermonizing Secession and the Threats to the Republic}

Twenty years after Reverend Heman Humphrey delivered a sermon following the unanticipated death of William Henry Harrison, he again found himself preaching on a day of national fast amid national crisis. In 1841, Humphrey acknowledged his uneasiness about speaking of political matters from the pulpit, yet as a self-described patriot, he used Harrison's death to warn listeners about their dependence on political parties and politicians. With the secession of the Lower South in the winter of 1860-1861, Humphrey, now a minister in Pittsfield, Massachusetts, once again viewed his sermon as an opportunity to convey to his congregation the reasons for the crisis and explain how they might avoid God's judgment. "Why is it, that we are brought to the brink of a bloody revolution?" he asked his congregants. "We have brought it upon ourselves," he said. According to Humphrey, partisanship, profaneness, intemperance, Sabbath breaking, licentiousness, and most notably slavery were national sins that had provoked God's punishment. While the secession of southern states precipitated the prospect of a bloody war, the moment provided northern members of the eulogizing class a chance to invoke patriotism, republicanism, and religion in order to suppress threats both the North and South posed to their vision of democratic government and national identity. ${ }^{1}$

The secession crisis highlighted the complex, and at times contradictory, debate over democracy within competing nationalistic identities during the antebellum period.

\footnotetext{
${ }^{1}$ Heman Humphrey, Our Nation: A Discourse Delivered at Pittsfield, Mass., January 4, 1861, on the Day of National Fast (Pittsfield: Henry Chickering, 1861), 13. This chapter's view of nationalism is influenced by Susan-Mary Grant's North over South: Northern Nationalism and American Identity in the Antebellum Era (Lawrence: University of Kansas Press, 2000), 6.
} 
Democratization during the antebellum era set off a series of societal changes that destabilized traditional republican society. The corresponding rise of democracy and the increased infusion of religion in the slavery debate facilitated the growing antislavery movement and the subsequent vehement defense of the institution by southerners who increasingly fused slavery into their conceptions of national identity. This dissertation contends that influential men throughout the nation voiced concerns that democratic culture threatened republican values and the social structure that helped them maintain prominent positions in their communities. Yet, slavery was the subject of democratic debate, and each side of the issue worked to defend or oppose slavery through democratic means. For decades, eulogists of respected politicians warned their audiences that the excesses of democracy would ruin the nation. By 1861, they believed many of their prophecies appeared to be coming to fruition. ${ }^{2}$

Although Humphrey spoke of several national sins plaguing society, he spent the majority of his sermon discussing slavery's centrality to the crisis. "It is slavery, which has been gnawing at the vitals of the body politic, and bringing on this tremendous outbreak for more than thirty years," he declared. He deemed that there would be no secession without slavery and outlined the reasons why the institution lay at the heart of

\footnotetext{
${ }^{2}$ Civil War causation continues to lead to a wide array of scholarship, as discussed in the dissertation introduction. Michael F. Holt and William Gienapp, two preeminent political historians, point to the breakdown of the two-party system and the failure of democracy as the reason for disunion. While slavery fits into their understanding of why the party realignment took place, this dissertation attempts to bridge the gap in understanding how slavery and democracy led to the secession crisis. While the excellent studies of Holt and Gienapp detail the party system breakdown, they do not appreciate the antiparty complexion of the nation that played a significant role in the dissolution of the two-party system, which as I argue, was a tenuous system since its inception. Rather than place the emphasis on the parties, the attention should be on the antiparty complexion of the political culture that looked at parties with suspicion and through a republican lens. The party system fit within a broader debate over the merits of democracy throughout the nation, as citizens grappled with the changing political culture and continued to view parties with suspicion rather than for salvation. See: Michael F. Holt, The Political Crisis of the 1850s (New York: Wiley, 1978), William Gienapp, "The Crisis of American Democracy, The Political System and the Coming of the Civil War." In Why the Civil War Came, ed. Gabor Boritt, (New York: Oxford University Press, 1996).
} 
the conflict. Sermons delivered on days of national fasts during the secession crisis illuminate how orators adopted the language and practice of mourning to discuss democracy's role in the crisis by eulogizing the death of the Union. A comparative study of northern and southern sermons displays the divided opinions about slavery and democracy throughout the North, especially in contrast to the largely united vision in the slave states. While there were abolitionist ministers, particularly in New England, who raised anxieties in the South, many clergymen across the North denounced their abolitionist colleagues for violating the religious role of the pulpit and causing sectional tension. Some saw abolitionism as a direct product of a hyper-partisan age brought about by the rise of democracy. Northern ministers concurred that slavery was central to the controversy, yet there was a significant divide among clergymen over the appropriate ways to deal with slavery during the crisis. A large number of northern ministers denounced fanaticism and hyper-partisanship in both regions and united on the belief that the constitution needed protection and that citizens had republican duties to secure its survival. Some eulogists reluctantly embraced democracy during the secession crisis in order to squelch secession. For the eulogizing class, the constitution gave a reason for northerners to unite around the cause of "Union," shrouding conflict about democracy. ${ }^{3}$

Southern ministers commented on the negative influences of democracy more than their northern counterparts, who often tried to obscure democracy entirely by focusing on issues of patriotism, slavery, and the constitution. Southern members of the

\footnotetext{
${ }^{3}$ There continues to be a debate about slavery's role in the beginning of the war in the minds of northerners. James McPherson, for example, states, "For reasons of their own most northerners initially agreed that the war had nothing to do with slavery." James M. McPherson, Battle Cry of Freedom: The Civil War (New York: Oxford University Press, 1988), 311. While true for many northerners, this study shows, however, that slavery was central to the crisis to some in the North. Eulogists, regardless of their opinion on slavery, understood that slavery was a primary reason for the secession crisis.
} 
eulogizing class united on the virtue and religious sanction of their slave society, and they were in unison about proslavery republicanism and the idea that the constitution was a compact of sovereign states. There was some division, however, over whether secession was the proper course of action to take during the winter of 1860-1861. Not surprisingly, Border States, which had a closer connection to free states and were not as socially and economically tied to slavery, had stronger unionist sentiment. Despite varying regional opinions on secession, Border State eulogists were in harmony over the threat that northern democracy posed to their social structure based on proslavery republicanism. Through fast day sermons, southern ministers sought protection and security by defining their societal vision as an American national identity. As historian Mitchell Snay rightly contends, the confession of sins in fast day sermons gave ministers a platform to explain and justify secession. ${ }^{4}$ Ministers, educators, lawyers, and politicians used the secessionist crisis to preach their vision of southern society and to portray it as a national vision in tune with the Revolutionary generation.

The uncertain political climate after Abraham Lincoln's election created an opportunity for southerners to turn their sectional nationalist ideology into a national identity by forming a new nation. Reverend James Henley Thornwell spoke of the threat to slave society on South Carolina's day of fast. Thornwell commonly warned his congregants about societal dangers, as previously discussed during his sermon after John C. Calhoun's death. In his fast day sermon, he continued to warn about the social

\footnotetext{
${ }^{4}$ Mitchell Snay, Gospel of Disunion: Religion and Separatism in the Antebellum South (Chapel Hill: University of North Carolina Press, 1993), 169. Snay's excellent study of religion and southern separatism joins others in giving due attention to the significant role of religion during the secessionist crisis. This dissertation agrees with historians such as Snay and David Potter that clergymen from the pulpit were central in speaking about the danger facing the South and promoting separation from the Union in order to protect southern society. For Potter's viewpoint, see: David Potter, The Impending Crisis: 1848-1861 (New York: Harper \& Row, 1976), 501.
} 
upheaval and decay that faced southern society. He discussed the sins within society and cautioned his listeners: "The tendency to sink our institutions into a pure democracy has been steadily growing." Democracy threatened Thornwell's nationalist vision. Although a unionist during the $1850 \mathrm{~s}$, he saw secession as a justifiable course in order to reassure southerners of the righteousness of a slave society and the idea that the constitution was a compact of sovereign states. Both of those positions fit within the desired national identity of southerners. ${ }^{5}$ Southerners understandably viewed slavery as an institution protected by the constitution and fought to defend their national vision. Throughout the antebellum era, southern eulogists consistently promoted proslavery republicanism to argue against democratic impulses. The federal constitution that upheld property rights, along with the nation's history as a slaveholding republic, was something worth fighting for to fend off democratic forces that threatened the southern way of life. ${ }^{6}$

Throughout the antebellum era, the eulogizing class debated the ramifications of democracy on politics, religion, and society during moments of national loss. Ultimately, influential southern men saw democracy as a threat to slavery and their power structure that protected the institution on federal and state levels. Lincoln's election appeared to justify their warnings of a tyrannical majority and eulogists attempted to use it as proof that the Founders intended for the constitution to be a compact of sovereign states to

\footnotetext{
${ }^{5}$ J.H. Thornwell, "Our National Sins: A Sermon Preached in the Presbyterian Church, Columbia, S.C., on the Day of the State Fast, Nov 21, 1860" in Fast Day Sermons: or the Pulpit on the State of the Country (New York, Rudd \& Carleton, 1861), 41-42. Fast Day Sermons was published in 1861 to give an indication of the significant sermons and speeches given throughout the North and the South on the secessionist crisis. It states in the preface, "The particular sermons here introduced, have been chosen not in the interest of any party, but as fairly representing the mind of the country, both North and South."

${ }^{6}$ The antidemocratic nature of the South has begun to receive more attention. Most recently, Michael Bernath has shown how southern antidemocrats saw the Confederacy as a moment for reform. While they were extreme compared to most, even denouncing aspects of the Revolution, they were the extremists of a position that this dissertation argues was more mainstream than typically considered. Michael T. Bernath, "The Confederacy as a Moment of Possibility." The Journal of Southern History 79, (2013): 298-338.
} 
avoid such an issue. While northern ministers did not preach in favor of the compact theory, they nonetheless opposed aspects of democratic culture. Yet, views on democracy oscillated when a southern oligarchy appeared to throw the nation into anarchy by not upholding a democratic election. Secession equated to anarchy in the eyes of northern ministers who saw the crisis as their moment to preach societal stability through defense of the law and the constitution - issues they had been warning were under threat in their eulogies for the previous two decades. Secession was akin to corruption and speaking out against such action allowed ministers to address the internal threats to traditional republicanism, the legacy of the Revolution, and their nationalist vision. Under the guise of patriotism, ministers in both regions preached for sectional visions of national identity. The way to fix God's anger over national sins was to correct them, which not surprisingly also scaled back the fanaticism and cultural decay that the eulogists had warned about for decades. Ministers invoked patriotism and the current sectional crisis to rally citizens behind their nationalist desires and to restore republicanism and suppress concerning elements of society. ${ }^{7}$ In a democratic republic where soon thousands of men would enlist to fight to vindicate a democratic "Union," a eulogizing class used nationalism as a tool to secure law and order and to suppress the unwanted ramifications of democracy. ${ }^{8}$ Ultimately, contested definitions of democracy thrust the nation into war.

\footnotetext{
${ }^{7}$ Sean A. Scott notes how many northern clergy rushed into the political atmosphere and had their judgment obscured by the prevailing patriotic fervor. He contends, "Most significantly, the line between religious beliefs and patriotism was becoming blurred so that many Northerners considered the Union to be sacred." Sean A. Scott, A Visitation from God: Northern Civilians Interpret the Civil War (New York: Oxford University Press, 2012), 22.

${ }^{8}$ Gary Gallagher, The Union War (Cambridge: Harvard University Press, 2011). Gallagher rightly places "Union" back as central focus for understanding why Union soldiers fought in the Civil War. "Union" had multiple meanings, and many citizen-soldiers saw secession as an affront to democracy and fought for that reason. The concept of Union was important to eulogists for the nation, yet they did not necessarily equate Union with democracy. Many used patriotism and love of the Union to obscure a democratic culture that they disapproved of and thought played a role in bringing about disunion.
} 
South Carolinians threatened secession for decades, and with Lincoln's election in 1860, those threats appeared to be coming to fruition. With the Whig coalition dissolved and the Democratic Party splintered, Lincoln and the Republican Party successfully gained enough electoral votes to capture the presidency under a free soil and free labor platform for the federal territories. As concerns over which states would follow South Carolina swept throughout the nation, outgoing president James Buchanan proved not up to the task of seeking a resolution. He did, however, designate January 4, 1861, a national day of fast due to the growing crisis. Businesses and offices closed throughout towns and cities across the North for the day of fast. Some, however, chose not to participate due to frustration with Buchanan. Southern clergy more commonly ignored the day of fast and saved their sermons on the crisis for state days of fasting or other moments to appropriately discuss the national emergency. ${ }^{9}$ Others used the day to speak out against the Buchanan administration's handling of the secession crisis. ${ }^{10}$

Participation in the day of national fast enabled ministers to voice frustration with the course of the Buchanan administration and to directly discuss politics for religious reasons. Some ministers, typically those who were more conservative, denounced any discussion of politics, but others disagreed with that notion. Unitarian Reverend Henry Bellows made certain to reaffirm to his congregants at All Souls Church in New York that he did not deliver his sermon in support of Buchanan. "It would be gross hypocrisy in me to leave it to be inferred that I share any of the feelings or opinions, political or

\footnotetext{
${ }^{9}$ Many did not recognize the call for national fast, but there were still some who accepted the call throughout the South. For examples, see: "Fast Day," Macon Telegraph, January 5, 1861, and the "City Items," Richmond Whig, January 4, 1861.

${ }^{10}$ Snay, Gospel of Disunion, 162-163; Scott, A Visitation from God, 14.
} 
religious, which are avowed in the call for this special fast," he proclaimed. ${ }^{11}$

Presbyterian Reverend Horace C. Hovey supposed that he had a duty to speak of political issues, rebuffing the concerns by some about speaking of political matters from the pulpit. Preaching in Coldwater, Michigan, Hovey contended that Buchanan’s proclamation presented a "pitiable picture" of the president. He continued, "We see an imbecile old man wringing his hands, in the halls of the White House, instead of a hero, wielding his sword" at the South Carolina traitors. Despite Hovey's strong antislavery sentiments, he longed for a man akin to Andrew Jackson who defended the Union against nullifiers during the Nullification Crisis. He hoped for a "great man" to solve the problems that he believed were created by democratic politics. Hovey, who during the war eventually served in the United States Christian Commission, continued to criticize Buchanan. Hovey capitalized on the ambiguous reference Buchanan made to "national sins" to assert party spirit, territorial expansion, and slavery as sins that needed correction. $^{12}$

Ministers understood partisan strife as a central moral deficiency of democratic political culture. There had been persistent uneasiness with the rise of the two party system along with the democratization of the nation since the $1830 \mathrm{~s}$. The antiparty rhetoric in orations displayed the concerns about the corrosiveness of party strife. Hovey warned that party spirit made men "deaf to argument, remonstrance, and entreaty," and

\footnotetext{
${ }^{11}$ Henry W. Bellows, "The Crisis of our National Disease: A Sermon Preached at All Souls Church, New York, on the Day of the National Fast, Jan. 4, 1861," in Fast Day Sermons, 294. For similar sentiments against Buchannan, see: Joseph P. Thompson, The President's Fast; A Discourse upon our National Crimes and Follies, Preached in the Broadway Tabernacle Church, January 4, 1861 (New York: Thomas Holman, 1861), 7-9.

${ }^{12}$ Horace C. Hovey, The National Fast: A Sermon, Preached at Coldwater, Mich., January 4, 1861 (Coldwater: Republican Print, 1861), 4.
} 
that the fraud and violence associated with party spirit contributed to the current crisis. ${ }^{13}$ Dr. Alexander Mercer, former University of Pennsylvania professor who at the time of his sermon was an assistant minister in Boston, similarly placed much of the blame on partisanship and lack of republican virtue amongst citizens. In his sermon, American Citizenship, - Its Faults and their Remedies, Mercer exhorted honest and brave men to rise up during the troubled times. He contended that the fears of too many citizens kept them from speaking freely and that "the best opinion of the best, fearlessly given, is not heard, while rude and partisan outcry is distinctively given, and is called the public voice." To Mercer, the blame lay with a democratic political system that drowned out the opinions of the "best" citizens. ${ }^{14}$

Eulogists spoke against the extreme partisanship endemic in democratic politics in order to make appeals directly to citizens to change the culture of politics. Ministers stressed the need to lessen the hold demagogues had while simultaneously promoting religion in order to fill the void. Although eulogists were not eulogizing a particular person, they used the secession crisis as an opportunity to adopt mourning language to eulogize the Union's death. Fast day sermons displayed how the form of eulogy offered elite men the opportunity to criticize demagoguery, while simultaneously acting as demagogues. Mercer presumed that he spoke on behalf of "the people" when he asserted that "We want loyalty, not to a man or a party, but to Law, to the State, and to whatever is Higher; and hence we want a public sentiment as to the duty of citizens" for public judgment for the class of men who threatened the nation. He envisioned honest men replacing the demagogues that put the nation in peril. Mercer's sermon exhibited the

\footnotetext{
${ }^{13}$ Ibid., 7.

${ }^{14}$ Alexander G. Mercer, American Citizenship, - Its Faults and Their Remedies: A Sermon for the Day of National Fast, January 4, 1861 (Boston: Little, Brown and Company, 1861), 10.
} 
uneasiness with which men of the eulogizing class debated the merits of a democratic republic. He condemned the public for neglecting their duty since "so great a mass" gave individual men little power, and he challenged his listeners to throw off the manacles of partisanship and to reclaim their republican spirit. "I believe in the people in a moment like this, and I care not a whit for parties, and have no faith in mere party-men," he declared, continuing to affirm that "the people" had to take power away from partisans. Mercer claimed to have faith in citizens, but his sermon illuminated his concerns of their success to defend the country. His oration provided an opportunity to instill among his listeners the qualities that he wished they possessed, and he hoped to galvanize their patriotic and republican spirit in order to scale back the power that democratically elected representatives held. ${ }^{15}$

Some clergymen lashed out at party spirit in order to rein in threats to the stability of the community while simultaneously advocating for their vision of politics. Reverend T.P. Bucher lamented the lack of statesmen during a time when "political madness" prevailed. In his fast day sermon at the United Presbyterian Church in Gettysburg, Pennsylvania, he placed importance on his task as a reverend during such tumultuous times, and claimed he trembled in his position "in view of the delicacy and responsibility of the pulpit." Similar to Bucher, ministers across the nation claimed to be reluctant leaders who understood the significant role they now played during the crisis. The modest approach to their supposed elevated importance paralleled the republican spirit that they preached to their congregants. Eulogists, as they did during the last two decades, depicted

\footnotetext{
${ }^{15}$ Ibid., 12, 27. Like many of the sermons delivered for the National Fast, newspapers published extracts from the sermon. The Philadelphia Inquirer printed a section of Mercer's sermon and praised it as an "able and patriotic discourse." "The Philadelphia Inquirer Philadelphia, Tuesday, Feb 19, 1861 a Patriotic Sermon," Philadelphia Inquirer, February 19, 1861.
} 
themselves as reluctant citizen leaders, yet they actively sought to shape democracy by critiquing it when they urged their listeners to remove the sins they condemned. Bucher denounced the excessive party spirit that precipitated much of the hostilities. He warned that party spirit "when excessive, when it exists to the extent it does amongst us, is rather a curse than a blessing." According to Bucher, partisans hated each other, which led to disregard for their obligations to citizens and the common good. Bucher's view of political partisans was antagonistic to the Christian republican society that clergy desired during the two decades before secession. The political system that developed alongside democracy elevated unworthy men to positions of importance and excused citizens from their duties to the community. ${ }^{16}$

Clergy received criticism for supposedly tainting the pulpit by speaking of political issues such as abolition. Conservative ministers condemned their colleagues who preached an abolitionist agenda by placing abolition under the umbrella of democratic politics. Bucher combined abolition with the decline of the press and the rise of party aggrandizement and warned of the ways that excessive party spirit damaged society. "Look again at party spirit finding its way out through the pulpits of the land, of New England mostly," he cautioned his listeners, continuing, "There are preachers of politics as well as of the gospel." To Bucher, the abolitionist rhetoric was not about God, but rather the commercialization of the pulpit since "sensational-preaching" attracted crowds and sold pews. ${ }^{17}$ Alexander Mercer similarly took aim at abolitionists, labeling them fanatics about slavery. He cautioned that even though they were a small group, they nonetheless shaped the opinion of American slavery in Europe and gave the South

\footnotetext{
${ }^{16}$ T.P. Bucher, Union National Fast Day Sermon, Delivered in the United Presbyterian Church, Gettysburg, PA., Friday, January 4, A.D. 1861 (Gettysburg: H.C. Neinstedt, 1861), 6-7, 12.

${ }^{17}$ Ibid., 14.
} 
justifiable anger over the dangerous rhetoric they expressed. ${ }^{18}$ Before broaching the topic of abolition, Benjamin Allen appealed to the patriotism of his Massachusetts congregants while delivering a fast day sermon in Marblehead. Allen asserted that he no longer was speaking as a Massachusetts man or a politician, rather as an American citizen who loved his country. He exclaimed to his congregants, "I address you, not as politicians, but as American citizens - Christian patriots." Allen stressed the importance of "Christian patriots" to do the duties that God and the country required. In Allen's view, one of those was fighting against the causes of the present danger, and he believed that abolitionism was the greatest evil causing the tension. Allen contended that abolitionists "infused the poison into the veins of the social organism," and blamed his fellow New England clergymen for much of the fanaticism. He argued that the New England pulpit had become "abolitionised," and condemned such men for preaching that all slaveholders were heinous criminals and unchristian men. Allen labeled himself as an American first and foremost, which indicated his desire to identify his conservative views as American and national. Abolitionists were a product of a partisan age that threatened his particular vision for the Union, just as secessionists did in the South. ${ }^{19}$

Abolitionists became an easy target for conservative ministers who had concern for the changes taking place within northern society. In addition to being an impetus for the sectional agitation plaguing the country, Allen blamed the "storm of Abolition

\footnotetext{
${ }^{18}$ Mercer, American Citizenship, 15-16.

${ }^{19}$ B.R. Allen, The Constitution and the Union: A Sermon Preached in the First Congregational Church in Marblehead, on the Occasion of the National Fast, January $4^{\text {th }}, 1861$ (Boston: J.H. Eastburn, 1861), 16, 20, 21. Several northern ministers charged their New England colleagues with much of the blame for the sectional crisis. John C. Lord, for example, echoed the words of Mercer and Allen, charging that a "class of politicians and editors are ever fomenting, especially in New England, the discords of the times, sowing the dragon's teeth of jealousy, suspicion and hatred, provoking a storm" which he believed only patriotism could thwart. John C. Lord, Causes and Remedies of the Present Convulsions: A Discourse (Buffalo: Joseph Warren \& Co., 1861), 15.
} 
fanaticism" for also breaking apart national churches and societies. He also charged abolitionists with infiltrating northern politics. He used the right of petition, a fundamental aspect of democratic government, as an example of abolitionists meddling in politics and threatening rights given to the South in the constitution, and highlighted those who helped destabilize the South by assisting runaway slaves. Ultimately, he declared that the fanatical nature of the movement gave southerners rhetorical ammunition to push for separation, defend the institution, and seek its extension. Concerning the South's sufferings at the hands of abolitionism, Allen asked his congregants there was any wonder why the South was "determined on secession, if nothing else will save her from the principles and results of the recent election as she understands them?" He used patriotism and nonpartisan rhetoric to send a partisan message. For the supposed sake of patriotism, Allen asserted his views on abolition's ramifications on both the North and South. Abolitionism was a product of hyperpartisanship and risked the traditional republican foundation of the nation. Allen hoped to stem that tide as best he could during his sermon. ${ }^{20}$ Of course, using orations during moments of national mourning to speak out against aspects of democratic culture was not unique to the secession crisis. Eulogists had been using their orations to deliver such concerns throughout the antebellum era.

Eulogists debated the meaning and influence of abolitionism in their orations on the secessionist crisis. Reverend Henry Van Dyke's sermon, The Character and Influence of Abolitionism, delivered in the First Presbyterian Church in Brooklyn, gained attention

\footnotetext{
${ }^{20}$ Allen, The Constitution and the Union, 30. For similar sentiments, see: Lord, Causes and Remedies, 910. Lord accused northern fanaticism's crusade against slavery as being the reason for the South responding with the extreme position of glorifying slavery. Those extremes he argued were "unquestionably the origin of the present disturbed condition of our common country."
} 
for his characterization of the movement. Van Dyke's criticism began with the abolitionist stance that slaveholding was sinful. He confirmed that abolitionists "must believe that slaveholding is morally wrong," and argued that the bible showed no indication that slavery was a sin. "When the Abolitionist tells me that slaveholding is sin," he preached, "I point him to this sacred record, and tell him...that his teaching blasphemes the name of God and His doctrine." Van Dyke and other northern ministers who were either proslavery or at least denounced attacks on slavery used the bible (as southerners did) to show that slavery was not a sin. They contended that abolitionist and antislavery ministers deserved criticism for preaching against the bible's authority. ${ }^{21}$

The sermon delivered by Van Dyke received both support and rebuke from members of the eulogizing class. Doughface Judge George Woodward spoke at Union rally across from Independence Hall in Philadelphia, and cited Van Dyke's definition of abolitionism in order to bolster his own stance on slavery and the sectional crisis. Woodward brought up the issue of whether or not slavery was a sin during his speech at the rally. "What right has the Abolitionist to pronounce it a sin?" asked Woodward during his speech. He referenced Van Dyke's sermon and definition of abolitionism. "I accept the definition," he exclaimed, stating, "and according to it many of our best Christian people must be accounted Abolitionists; for it is astonishing how extensively

\footnotetext{
21 "The Character and Influence of Abolitionism: A Sermon Preached in the First Presbyterian Church, Brooklyn, December 9, 1860," in Fast Day Sermons, 135, 139. For another study that examines Van Dyke's sermon and the biblical interpretation of slavery during the secession crisis, see: Mark A. Noll, The Civil War as a Theological Crisis (Chapel Hill: University of North Carolina Press, 2006). For more on anti-abolition sentiment in northern sermons, see: Lord, Causes and Remedies of the Present Convulsions, 9-10; John O. Fiske, A Sermon on the Present National Troubles, Delivered in the Winter Street Church, January 4, 1861, the Day of National Fast (Bath: The Daily Times Office, 1861), 5-6; George Duffield, Our National Sins to be Repented of, and the Grounds of Hope for the Preservation of our Federal Constitution and Union: A Discourse Delivered Friday, January 4, 1861, on the Day of Fasting, Humiliation and Prayer Appointed by the President of the United States (Detroit: Free Press Mammoth Book and Job Printing, 1861), 14.
} 
the religious mind of the north has admitted into itself the suspicion, not to say conviction, that slaveholding is a sin." Woodward's discussion of sin during the public rally reinforces the prominent role of religion beyond the pulpit in American public life. Religion pervaded political discourse during the antebellum era. Clergy justified discussing politics as a religious concern. Politicians likewise brought religion into politics. Woodward, similarly to ministers who preached against fanaticism for the sake of law and order, also made sure to note that sin was a transgression of the law, yet slavery did not fit into that category. ${ }^{22}$ Van Dyke's sermon found a favorable audience from conservatives looking to remove slavery from democratic debate. Others, however, took issue with his interpretation of the bible regarding slavery.

Taylor Lewis, Professor of Classics at Union College, rebuked Van Dyke's interpretation to show that servitude in the bible was not a viable argument in support of American slavery. He claimed Van Dyke's sermon was a defense of slavery, and that the men who support slavery caused the sectional tensions. Lewis explained that the abolitionists that Van Dyke condemned were "a mere handful of men" who grew "smaller ever since the formation of the republican party gave a constitutional and conservative vent to the anti-slavery feeling." He charged Van Dyke with equating abolitionist sentiment with those against slavery in the North, and surmised that lumping such a large group of northerners in with the small abolitionist movement simply moved the "middle way" over to the proslavery position. Ultimately, Lewis implied proslavery

\footnotetext{
${ }^{22}$ Speech of Hon. George W. Woodward, Delivered at the Great Union Meeting in Independence Square, Philadelphia, December 13, th 1860 (Philadelphia: Age Office, 1863), 10.
} 
advocates opportunistically attacked abolitionism despite the movement offering little tangible threat. $^{23}$

Newspapers also debated sermons and the propensity of clergy to speak about political issues on fast days. Van Dyke's sermon received a mix of reviews in the northern press. The Ashtabula Weekly Telegraph printed a lengthy review of Van Dyke's sermon and criticized his interpretation of American slavery. The paper denounced Van Dyke for ignoring the chattel principle when defining slavery. "Hence, it is perfectly obvious, that the 'chattel' principle is the life's blood, of American slavery," the paper declared, and continued to censure proslavery individuals like Van Dyke for not preaching that aspect when comparing American slavery to biblical slavery. ${ }^{24}$ Newspapers such as the Columbian Register countered by crediting Van Dyke for speaking out against fanatical preaching by clergy against slavery. Others spoke more broadly about the trend of clergy to speak of political issues. ${ }^{25}$ The New York Herald commented that clergy were "useful to the community when they keep strictly within the limits of their profession," but were out of their element when they spoke of politics and were even more incompetent to direct the public mind than politicians. While ministers viewed themselves as outside the realm of partisanship, their sermons nonetheless became another voice in the contested democratic culture. Even conversations among eulogies, cartoons, and public commemorations that spoke out against democratic culture were democracy in action. Citizens argued about and against democracy in the

\footnotetext{
23 "Patriarchal and Jewish Servitude No Argument for American Slavery" in Fast Day Sermons, 179. Lewis's rebuttal to Van Dyke's sermon was originally published in The World.

24 "Sermon," Ashtabula Weekly Telegraph, February 9, 1861.

25 "Untitled," Columbian Register, January 5, 1861.
} 
antebellum era. Dissenting voices about democracy helped make democracy and reflected democracy's combative nature. ${ }^{26}$

Criticism of the abolitionist movement did not only come from ministers sympathetic to slavery. Antislavery clergy also felt compelled to differentiate their stance from abolitionism. Apostolic Minister M.B. Smith made sure to take issue with abolitionists in his sermon, The Nation's Danger and the Nation's Duty. He also charged the South with attempting to perpetuate a system that "enlightened humanity recoils with abhorrence, and which almost the entire civilized world" repudiated. Speaking for those against slavery to his New Jersey congregation, Smith claimed, "we are not to be like those fanatics who have so long dwelt upon it that they can think of nothing else, and who have, strictly speaking, become men of one idea." ${ }^{27}$ Heman Humphrey similarly felt the need to distinguish himself from the abolitionist movement despite having ardent antislavery views. He felt compelled to state: "I have no sympathy and never had, with the rabid abolitionists. I think they have done a great deal of hurt by putting further off the day of emancipation, instead of hastening it." He claimed to quarrel with the system of slavery, and not the slaveholders, with whom he sympathized because they grew up with the institution. ${ }^{28}$ Clergy such as Smith and Humphrey feared the fanaticism of the abolitionist movement even though they had antislavery views. The perceived fanatical nature of the movement thus made abolitionists unable to be true republicans, as they threatened the security of the common good. Speaking out against the movement

\footnotetext{
26 "The Fast Day Union Sermon - The Clergy as Statesmen and Theologians," New York Herald, January 6, 1861. For more examples of newspapers discussing Van Dyke's sermon along with giving opinion on other fast day sermons, see: "Review," Belmont Chronicle, March 7, 1861; "Error and Correction - Prophecy and Fulfilment, [sic]" Liberator, January 1, 1861; “The Fruit of the Fast," New York Tribune, January 9, 1861.

${ }^{27}$ M.B. Smith, The Nation's Danger and the Nation's Duty: A Sermon, Preached in St. John's Parish, Passaic, New Jersey, on Sunday Afternoon, April 21 $1^{\text {st }} 1861$ (New York: John Q. Gray, 1861), 9.

${ }^{28}$ Humphrey, Our Nation, 17. For similar sentiments, see: Henry W. Bellows, "The Crisis of our National Disease," in Fast Day Sermons, 298-299.
} 
displayed a desire to rein in threats that could destabilize society and foster a mindset amongst "the people" to go against the law and to threaten community stability. With abolitionism largely rebuked in the North as it was in the South, eulogists differentiating themselves from the movement also made antislavery appeals to their congregants seem in tune with republicanism and not radicalized by the stigma of abolitionism.

Ministers divided over the meaning of the constitution and whether compromise over slavery was an option worth pursuing. The particular eulogist's view on slavery not surprisingly influenced whether they viewed compromise as still viable during the secession crisis. Charles Wadsworth, pastor of the Arch Street Church in Philadelphia, thought the issue was whether slavery was one of the sins that had provoked God's wrath. "Is slavery itself the evil for which God is punishing us?" he asked his congregants. Wadsworth echoed the sentiment of southerners in maintaining that the answer was unhesitatingly no, primarily because the nation had been a slaveholding republic since its inception and because God did not destroy nations for acts that were not plainly forbidden. Wadsworth did not see it as his concern to address the sinful aspects of slavery to his congregants who owned no slaves. The question to Wadsworth rested with "Wherein, then, have WE sinned in regard to this thing that troubles us—Slavery?" He did not view it as a concern of northerners, and argued that they should have no more concern with southern slavery than with Russian serfdom. He also thought it was sinful how northerners launched "arrows poisoned with the venom of most malignant passions" at their southern brethren, and who denounced all slaveholders as living in shameless sin. He stressed the importance for northerners to avoid the extreme positions of secessionists in the South and those who balked at compromise in the North, whom he viewed as 
equally "insane and abandoned." ${ }^{29}$ Conservatives consistently saw slavery as a main reason why democracy was dangerous in the two decades before the Civil War. Eulogists felt forced to discuss the institution because they believed democratic political culture fostered extremism.

The issue of compromise during the crisis spoke more broadly to contested definitions of democracy throughout the antebellum era. Conservative eulogists had long praised the compromises of past politicians. During the secession crisis, they took aim at those politicians who did not desire compromise. Eulogists now appealed directly to "the people" not to just look back longingly to the past, but to put the lessons past eulogies instructed them on and speak out in favor of compromise. Eulogists desiring compromise found their position grounded in the constitution, the bible, and previous compromises of the antebellum era. Buffalo Presbyterian John C. Lord used scripture to make his case for both sides coming together for the sake of compromise. "It is literally true that God is saying in his own providence to the North 'give up,' and to the South 'keep not back,'” he exclaimed in his fast day sermon. He deemed it necessary that the North relinquish its antagonism to the constitutional guarantees protecting slavery and, "unless the free states give up their unlawful intermeddling with the domestic affairs and local institutions of their neighbors," Lord believed it would lead to an unavoidable bloody collision. He insisted that compromise remained possible if the North stopped meddling in the institution and southerners accepted proffers of peace. If so, then a "peaceable settlement of our difficulties may be expected. ${ }^{30}$ Benjamin Allen reiterated such a rationale and

\footnotetext{
${ }^{29}$ Charles Wadsworth, Our Own Sins: A Sermon Preached in the Arch Street Church, on the Day of Humiliation and Prayer, Appointed by the President of the United States, Friday, January $4^{\text {th }}, 1861$ (Philadelphia: King \& Baird, 1861), 12-13, 16.

${ }^{30}$ Lord, Causes and Remedies, 16.
} 
asserted that the constitution was a compromise that set a tradition of compromise for the nation - a tradition that secessionists and abolitionists threatened. By showing all of the compromises in the constitution, he hoped to convince his listeners that compromise was in harmony with the republican origins of the constitution and the surest way to preserve the country. ${ }^{31}$ The constitution and patriotism lay at the heart of the argument in favor of compromise. Ministers advocating for compromise maintained that while slavery may be undesirable, it was not worth risking the dissolution of the Union. Compromise had been a habit of democratic politics since the constitution's formation, and had kept the country united and prosperous. Allen's definition of democracy again displays the contradictory role eulogists had in making democracy. While some viewed compromise as a quintessential part of it, others saw democracy as the struggle between political parties for their own ends. To Allen, it was time again for dutiful citizens to rise up amid the fanaticism of both sections concerning slavery and find a compromise that would save the Union. While earlier in the antebellum era eulogists tried to limit democracy's effects by admiring republicanism and valorizing past politicians for compromise, now many attempted to use the democratic approach of appealing to "the people" to advocate for compromise and shape democratic debate. ${ }^{32}$

\footnotetext{
${ }^{31}$ Allen, The Constitution and the Union, 8-10. Many ministers, similarly to the way Allen did, showed the history of the United States in order to justify their position in favor of compromise. For example, John O. Fiske, preaching in Bath, Maine, asserted, "We must exercise largely the spirit of concession and compromise in the adjustment of our affairs." He continued to note, "Our father were not in favor of the perpetuation of slavery, and yet consented to its continuance and protection where it is." Fiske, A Sermon on the Present National Troubles, 16.

${ }^{32}$ Newspapers also joined the debate over compromise when they covered fast day sermons. For example, the Columbian Register criticized Reverend Hawes of Hartford for supposedly claiming, "compromises are against God." The Register used a previous address by Hawes to discredit his current position against compromise for the secession crisis. Columbian Register, January 12, 1861. Reverend A.D. Benedict touted conservatism and compromise during his Fast Day sermon, and alluded to conservatism being the antithesis to partyism. A.D. Benedict, Our Republic, a Brotherhood. A Discourse Delivered in St. John's Church, Delhi, N.Y., on the National Fast Day, Jan. $4^{\text {th }}, 1861$ (Delhi, 1861), 9.
} 
The constitution also served as justification for those who spoke out against further compromise in order to squelch sectional tension over slavery. M.B. Smith believed that time for compromise was too late when he spoke just after the firing on Fort Sumter. "The day of forbearance and compromise has passed, and the government has spoken. And the people are speaking, too. Every man must speak. This is not time for neutrality. If such a thing ever was possible, it is impossible now," he lamented. To those against compromise, the constitution was akin to a sacred document, and there was little room for compromise. The constitution lay at the center of the arguments by those both for and against compromise. More broadly, upholding the constitution enforced the law, and ministers resoundingly desired the preservation of law and order even though they disagreed on the most appropriate way to do so. Smith appealed to the patriotism of his listeners in order to rally them behind the constitution and the Union. He stressed devotion and loyal allegiance to the government, which God commissioned to save the constitution from destruction. ${ }^{33}$

Some ministers believed that further democratic initiatives for compromise were futile. Heman Humphrey believed compromises during the country's history cut against the republican roots of the nation and exacerbated the sectional tensions. "There have been a good many compromises tried, each of which has widened, rather than healed the breach," Horace Hovey echoed the opinion that compromise no longer was a beneficial course of action. ${ }^{34} \mathrm{He}$ reminded his listeners that slavery and liberty had collided since

\footnotetext{
${ }^{33}$ Smith, The Nation's Danger and the Nation's Duty, 11-12. Some ministers touted democracy in their antislavery sermons. Joseph Thompson used the antislavery impulses of the Founding Fathers to argue against compromise and against slavery. He touted Democracy, citing Thomas Jefferson as the "Father of Democracy," and warned that idolatry of the Union had brought God's rebuke because it masked the sins of the country. Thompson, The President's Fast, 17-21.

${ }^{34}$ Humphrey, Our Nation, 26.
} 
the nation's founding, and charged men of being afraid to tackle the issue head on and making compromises at the expense of future generations. Hovey now considered it the right time to settle the issue. "Compromise would only postpone the final day of settlement. It might as well come now as ever!" He lamented that the slavery issue would only become increasingly complicated, and now was the time to seek resolution rather than compromise. The sermons indicate that the meanings of the republican past were as contested as the democratic present. The cultural act of eulogy was a figurative battleground to fight for interpretations of the republican past and what those memories meant to the present day. In addition, eulogists increasingly used their orations to exhort action by "the people," rather than primarily use the act of eulogy to deliver jeremiads against democratic political culture. ${ }^{35}$

Most eulogists advocated for the preservation of law and order through the same ideological lens, despite varying positions on the democratic value of compromise. Eulogists both for and against compromise appealed to patriotism and invoked the Revolution in order to give credence to their position. The intention of many ministers was not to revolutionize society, but rather was to preserve it. When the possibility of war became likely in the spring of 1861, abolitionist pastor Charles E. Lord justified why the time for compromise had passed and why northerners should fight if necessary. "We fight not only for the government sacred by the memories of the revolution, dear to us by the stories of our ancestors, loved by the blessings innumerable that we have enjoyed under the constitution," and also for the calamities that a dissolved nation would bring. Acquiescence now threatened society, since the South was breaking the law by not

\footnotetext{
${ }^{35}$ Hovey, The National Fast, 10-11. Anti-compromisers tended not to be as conservative as those advocating for compromise, especially regarding the issue of slavery. For another antislavery and anticompromise sermon, see: Thompson, The President's Fast, 11-13.
} 
accepting the results of a democratic election. If the North allowed states to secede, that could endanger the entire nation and eventually dissolve it into anarchic states and sections. He explained to his listeners that the crisis came about "because one-third of the people dare to say that two-thirds shall not have their way in accordance with the law of the land." 36

Willingness to go to war became a moment for democratic government to prove its virtue and a time for men to prove they were worthy of a democratic government. For William Goodrich, Yale educated and pastor of the First Presbyterian Church in Cleveland, there were times when war was a divine necessity. "Compromises have been vain," he exclaimed in his sermon for war following the firing on Fort Sumter. He contended that the "peaceful ballot" could be used to elevate mankind, yet the despotic nature of slavery corrupted government and took away the liberties of citizens. To Goodrich, the future of democracy was at stake during the secession crisis. "Yes, we have great work on hand," he warned, but he reassured his congregants, "We are to prove in the face of all nations, that a popular government is strong enough to punish treason." The moment had arrived for northern men to earn the republic they inherited and to preserve it for future generations. He stressed that they had the ability to validate popular government to the world and the fortitude to finally strike a fatal blow to slavery. Ultimately, the question was whether "the people" had the necessary virtue to do what was necessary. Goodrich's sermon displays how meanings of republicanism and democracy were changing by the secession crisis. Now some eulogists changed their

\footnotetext{
${ }^{36}$ C.E. Lord, Sermons on the Country's Crisis, Delivered in Mount Vernon, N.H., April 28, 1861 (Milford: Boutwell's Newspaper, 1861), 10.
} 
earlier definitions by exhorting "the people" to earn what they previously believed was bestowed. $^{37}$

For many ministers, slavery endangered the republican foundations of society. Henry Bellows viewed slavery as no longer compatible in a republican and democratic government. According to Bellows, the increasingly influential Slave Power had wielded its authority in the government to threaten the integrity of a plurality vote, and diffused the intelligence of the people. He accused the Slave Power of fearing the effects of the constitution and the Union, and planned secession to overthrow the government inherited from the founding generation. "Their leaders have been plotting it these twenty years, as the only refuge from the intolerable pressure of the preponderant national sentiment," he asserted during his fast day sermon. While Bellows did not concede the right of secession, he advocated letting the slave states leave if that was their true desire. However, he did not believe that to be so. He predicted that if war occurred, "It will not be a war for or against slavery — a war between one party and another party, or one section and another section, which will be precipitated, if the Federal and Constitutional authorities of the United States are gravely insulted and despised.” Rather, it would be a war in defense of "civilization against anarchy—a war of law and order upon piratical and barbarous assailant of the public peace and security." Bellows surmised that the North would not be going to war to force states to remain in the Union; it would be a war to "save order and civilization." Bellows's reasoning for why northerners should fight aligned with the northern sectional vision of republicanism. He concluded that they wanted ultimately "only faith in the Constitution as it is" and "faith in the right of

\footnotetext{
${ }^{37}$ William H. Goodrich, A Sermon, on the Christian Necessity of War (Cleveland: Fairbanks, Benedict \& Co., 1861), 6, 11-13.
} 
political majorities to exercise their legitimate power. ${ }^{\not 38}$ By 1861 , Bellows equated the democratic will of majorities as essential for civilization, and southerners increasingly contested that belief. For ministers across the North, the secession crisis instigated a period of self-examination. In order to have a republic in which citizens respected the law, enforcing the constitution and the wishes of the public in free elections was essential. Ministers desired to control the actions and beliefs of their own congregants just as much as they tried to shape the political discussions of those residing in the South. Eulogists had to embrace democratic thought in order to use it against southerners who threatened the nation with secession.

The crisis provided a moment to foster patriotism and rally citizens to do their duty as republican citizens. After Lincoln's call for 75,000 militiamen after Fort Sumter, Pastor Alonzo Quint of Jamaica Plain delivered a patriotic plea for citizens to rally to the Union's defense. In his sermon, The Christian Patriot's Present Duty, Quint, a Dartmouth graduate, pastor of the Mather Congregational Church, and owner-editor of the Congregational Quarterly, asserted that it was the duty of citizens to fight to preserve the Union. He maintained that while he never used his sermons for partisan warfare or political strife, the current crisis in the country caused him to recognize his call as a "patriot minister." He told his listeners "The War in which we are now engaged, is a war to sustain government against anarchy." Christian patriots had to uphold the law, and he suggested that if one state was allowed to leave the Union, then there would be no stopping a town or county from doing the same until anarchy reigned throughout the land. Despite the North's aversion for slavery, Quint defended northern states for upholding laws such as Fugitive Slave laws and argued that no attacks on southern rights

\footnotetext{
${ }^{38}$ Bellows, "The Crisis of our National Disease," in Fast Day Sermons, 302, 307-308, 310.
} 
had taken place. He continued to rally northerners by invoking the Revolutionary legacy and dubiously claimed that northern men had won the Revolution, and yet since then, the government had yielded to the South's demands. ${ }^{39}$ Quint lamented that southerners shifted away from the meaning of the Revolution, particularly when it came to slavery. "The fathers were not narrowed into provincial bigotry, by the doctrine of an allegiance to their State higher than that due to their country; they were Americans, not Southerners; statesmen, not politicians." He asserted that for decades slavery had demanded new sacrifices from republican men. The "bulk of slave-master politicians" had become arrogant and tyrannical, and the nation's republican spirit was now threatened. ${ }^{40}$

The disproportional influence that the Slave Power wielded helped solidify support for democracy in the North. Northerners increasingly saw the government controlled by a slaveholding oligarchy at the expense of the majority. ${ }^{41}$ Yet, the South's unlawful action reinforced the need for northern citizens to respect the law and be more vigilant in upholding their republican duty. For Quint, fighting for liberty in 1861 was akin to the struggle for independence from Britain. Now, a few powerful slaveholders suppressed liberty. The same men whom he criticized for "crushing the right of petition" were now determined to take away the right of free thought and fair elections. "Silence is not enough," he accused of the Slave Power, and continued to warn, "It is demanded that the majority shall bow to the minority; and that a little oligarchy should rule this broad domain." He charged that the struggle was one of a free people in the North fighting for

\footnotetext{
${ }^{39}$ Alonzo H. Quint, The Christian Patriot's Present Duty: A Sermon Addressed to the Mather Church and Society, Jamaica Plain, Mass., April 28, 1861 (Boston: Hollis \& Gunn, 1861), 6, 9-10.

${ }^{40}$ Ibid., 16.

${ }^{41}$ Adam Rothman makes similar conclusions in his excellent essay in an edited collection that looks at American elite classes from the Revolution through the New Deal. See: Adam Rothman, "The "Slave Power' in the United States, 1783-1865." in Ruling America: A History of Wealth and Power in a Democracy, Steve Fraser and Gary Gerstle, eds. (Cambridge: Harvard University Press, 2005), 64-65.
} 
"liberty and law" while the slave oligarchy fought solely for the liberty to oppress.

Southern secessionists threatened northern society through their disregard for the law.

While he was speaking of the South and secession, his words also served as a reminder to northerners about the need to uphold the law. "This war is the enforcement of laws, and it would ill become us to violate our own principles," and continued to urge that the South's recklessness needed to be extinguished. "We must still be a law-abiding people," he reminded them. ${ }^{42}$

Ministers promoted patriotism in order to rally the public to defend the Union and the constitution. "Our children should be taught patriotism. This has been too much forgotten," bemoaned Quint, and he reminded parents that it was their duty to teach "loyalty to law, love for our native land," to their children. Quint, who would practice what he preached when he became the Chaplain for the $2^{\text {nd }}$ Massachusetts Regiment during the war, advocated for everyone to do their republican duty by supporting the Union. He bemoaned the lack of military training among young men and stressed the need for military preparation. Everyone had a role to play in the upcoming conflict however. "Our young men should study practically the habits of the soldier. Our older men should be ready for home duty," he instructed his listeners. Women also had a valuable role to play. In addition to instilling patriotism in their children, he contended that women "should see that the labors of their hands furnishes all our volunteers with every needful supply. ${ }^{, 43}$ Charles Lord reiterated Quint's sentiments regarding the republican duties of citizens during the crisis. He conveyed to his listeners that everyone

\footnotetext{
${ }^{42}$ Ibid., 22.

${ }^{43}$ Ibid., 21, 22. For information on Alonzo H. Quint, see: Benedict R. Maryniak and John Vesley Brinsfield, eds., The Spirit Divided: Memoirs of Civil War Chaplains: The Union (Macon: Mercer University Press, 2007), 122.
} 
had a responsibility when the republic went to war. "Especially is this so with republics, the cardinal principle of whose constitution is, that the majority must rule," he stated, reminding of the need to uphold the law and the results of the 1860 election. All true patriots had to sacrifice for the good of the nation. "Every one should work for the country in his or her own sphere," he suggested, and expressed that people had particular positions in the war and that those duties needed to be followed. Those duties went beyond the officers and soldiers in the field. Workers at home and women had duties to uphold as well. "Let every man working in that sphere in which he is called of God, be not ambitious to get out of it, but emulous most nobly to come up to the full measure of what the country expects in the day of peril," Lord stressed. His words reflect the precarious position of pro-war ministers. While they appealed to patriotism and republicanism to galvanize citizens to obey the laws of God and the Union, they showed awareness that war could further unsettle society. Patriotism provided a rhetorical vehicle to garner support for a justified war. It also was effective for social control to minimize the radical nature of war and the democratic government for which they fought. ${ }^{44}$

Despite the pro-war mentality of some ministers, it did not mean that they prophesized a quick and easy struggle. The common Civil War narrative held by scholars and lay historians is one of naïveté by the populace in 1861 about what a war would entail. Much of that notion comes from Lincoln's call for 75,000 militiamen for 90 days of service. At a glance, it gives the impression that Lincoln and the war department considered the conflict resolvable in three months. In actuality, Lincoln's call for troops was based on a 1795 law providing for state militia into federal service. Just weeks after that initial call for troops, Lincoln called for 42,000 three-year army volunteers-months

\footnotetext{
${ }^{44}$ Lord, Sermons on the Country's Crisis, 14, 15.
} 
before the bloodshed along the banks of Bull Run proved that the war would not end quickly. ${ }^{45}$ Undoubtedly, many in both the North and South did have confidence their side could win the war in a quick and convincing manner. When ministers prophesized the impending war, however, they displayed a widespread understanding that war would be long and bloody.

Previous American wars, biblical violence, and similarities between the two sections provided a clear indication of the horrors of war. Heman Humphrey understood the bloody ending that slavery would inflict on the nation during war. "Yes, slavery is at the bottom of it all; and if it should result in a civil war, and torrents of blood should drown half the land, slavery, without which no such revolutionary madness could have occurred, will be answerable for all its horrors," he predicted when preparing his listeners for what lay ahead. ${ }^{46}$ M.B. Smith, who like Humphrey spoke against the institution of slavery and against compromise on the issue, contrasted the two sections on the imminent war. He argued that God was on the North's side and criticized southerners for "eagerness to begin the carnage of a war, which promises to be behind none of the wars of history, or of our own day, in its fearful scenes of rapine and bloodshed." He supposed that the violence that was to come was constructed by "partisans and demagogues" in the South who now unwisely pushed for their eventual demise. ${ }^{47}$ Visions of bloody war did not dampen convictions in the righteousness of the cause. Charles Lord, who opposed compromise, spoke of the "mournful spectacle" of fratricidal war. He bewailed the prospect of brethren from the same country "meeting in deadly conflict-the weeping of mothers childless, of fathers bereaved of their sons," and of "desolate homes" along with

\footnotetext{
${ }^{45}$ McPherson, Battle Cry of Freedom, 322.

${ }^{46}$ Humphrey, Our Nation, 27.

${ }^{47}$ Smith, The Nation's Danger and the Nation's Duty, 10.
} 
citizens sorrowing for loved ones wounded and dead strewn across battlefields. He noted that while northerners did not want it to come to that bloody destruction, but reinforced the righteousness of fighting for the Union. He argued for the "rightfulness of the sword" in self-defense and sacrifice in order to prevail. "But the course of the sword is marked by death, by devastation, by ravaged fields, by burning cities, by the sickening scenes of the hospital, the field of carnage," he warned. The war would be felt in all aspects of the community, he cautioned, and prepared his listeners for the impending debt, inflation, and scarcity of goods that would follow the death of so many on the battlefield. ${ }^{48}$

Ministers across the ideological spectrum concerning slavery and compromise forewarned of a bloody struggle. Reverend Edwin Bulkley, speaking at the Union Church in Groton, Massachusetts, reminded his listeners not to forget that while the secessionists were their enemies, they did once call them their brethren and compatriots. Northern ministers sometimes obscured the democratic struggle of the crisis and chose to focus more on brotherhood, patriotism, and civilization. He contended it was natural to have some trepidation for the appalling realities that awaited the nation. He gave reassurance that "It is no strange or reproachful thing, to be troubled by dark visions of woe and calamity which we see moving towards us." He understood the desire for prayer to be withdrawn from the widespread ruin and disaster that awaited the nation. ${ }^{49}$ Conservative Benjamin Allen also cautioned of the impending crisis when making his case for compromise. He implored his listeners to consider the "Anarchy or civil war, if not civil war followed by anarchy, and servile war" that faced them. ${ }^{50}$ Fellow advocate for

\footnotetext{
${ }^{48}$ Lord, Sermons on the Country's Crisis, 11, 13.

${ }^{49}$ Edwin A. Bulkley, Wars and Rumors of Wars: A Sermon Preached at the Union Church in Groton, Mass., on Sunday, April 21 $1^{\text {st }} 1861$ (Cambridge: Miles and Dillingham, 1861), 8.

${ }^{50}$ Allen, The Constitution and the Union, 11.
} 
compromise, John Lord, gave an accurate depiction of the possible war during his fast day sermon. He criticized the North's stance on slavery and hoped for compromise, but he also gave warning to southerners about the folly of instigating a war with the North. He contended that secession would unite all parties in the North, not on account of slavery, but because they threatened the integrity of the government and the Union. He cautioned that their slave society could not withstand a war against free states. "A Civil War must necessarily disturb the very foundations of society in the Slave States, while the Free States could easily spare more than half a million of men," Lord surmised. He predicted that slaves, even though they were better off enslaved in the South than freed men in the North, would nonetheless be "excited and deluded" by ideas of liberty and would become dangerous to the South. Although he argued a northern army would not incite or favor insurrection, he conceded that they might not have the ability to prevent it in areas where the white population was not large enough to police the slave community. He also warned about how war would alter the North even though he predicted that a free society would not lose to a slave society. He urged northerners to consider the cost of their eventual success. "They may save the Union, but at a loss which it will take a generation to prepare." If the North prevailed it would do so by making a desert of the territory between the Potomac and the Gulf of Mexico, lamented Lord. ${ }^{51}$

Despite the visions of a bloody war, northern ministers overwhelmingly promoted fervent patriotism during the secessionist crisis. While issues of slavery, compromise, and abolition caused division amongst them, there was unity in the righteousness of the Union and the vigorous promotion of patriotism and republicanism. Edwin Bulkley sensed ideological and religious motivation for the war in spite of the prospect of sickly camps,

${ }^{51}$ Lord, Causes and Remedies, 22, 23. 
empty homes, and bloody battles. He believed the country was learning a valuable lesson at a great price during the crisis, but believed ultimately it would prove worth the cost. $\mathrm{He}$ continued to warn: "Our vaunted prosperity has deluded us." Corruption of democratic politics frequently betrayed justice and liberty. Nevertheless, the crisis provided an opportunity to renew one's patriotism and correct the wrongs in society. Despite the concerns of the moment, Bulkley claimed to find comfort that "the people" were waking "from its slumberous negligence," and now could be trusted at a time of war. $\mathrm{He}$ contended that citizens displayed that "true patriotism is not dead beyond revival, nor sullied beyond purification., ${ }^{52}$

Bulkley used his pulpit to speak directly to a company of new volunteers into the federal army in his audience. He reassured the green volunteers that they did not join for the wrong reasons, and not merely because of the rush of public excitement, "nor the impulse of the moment, and much less a blood-thirsty vindictiveness and relish for war," for why they gave themselves up for the cause. Bulkley eased their minds, reminding them that their fathers, who also sacrificed for the sake of liberty, established the government they protected. They owed too much to that generation to ungratefully forsake it in the hour of trial. He concluded his message to the volunteers, stating, "The Lord return you to us in peace, and at last, through the washing of redeeming blood, to that heavenly country, where there are no wars, nor rumors of wars. ${ }^{, 53}$ The study of ministers during the secession crisis illuminates division over significant issues plaguing the nation. Ministers united on the necessity to protect the Union despite their disagreements on the best way to do so. Members of the eulogizing class adopted the

\footnotetext{
${ }^{52}$ Bulkley, Wars and Rumors of Wars, 11.

${ }^{53}$ Ibid., $15,16$.
} 
practice and language of mourning in order to eulogize the death of the Union. Orations provided a platform for speakers to define the crisis in their terms. Ministers promoted fervent patriotism in order to justify preaching against the sins that they thought needed correction. Eulogists tried to fix society's wrongs by appealing to patriotism and for a return of republicanism when the South threatened to plunge the nation into anarchy. The varied solutions offered by eulogists during the secession crisis are emblematic of the tensions that were central to democratic political culture. Eulogists criticized aspects of the culture, yet at times they looked to democracy as a solution. For decades eulogists warned about dangerous aspect of democratic culture, but the South's attempts to destroy the nation forced eulogists to respond with democratic appeals to "the people." Southern ministers similarly capitalized on the moment to initiate change within their society. While southerners came to different conclusions than their northern counterparts, they nonetheless did so through a similar ideological framework.

The Republican Party's success in 1860 signaled a grave threat to southern ministers who shared a national vision that sustained and protected the institution of slavery. Through proslavery republicanism and an interpretation that the constitution was a compact of sovereign states, ministers across the South united in defense of their sectionally driven nationalist identity that centered on the protection of slavery and restrictions against democracy. Similar to their northern counterparts, southern clergy used Thanksgiving and fast day sermons in order to proselytize for their views on slavery and government during the secession crisis. Clergy in the Lower South regardless of religious denominations endorsed secession once Lincoln's election threatened to 
destabilize the southern social and political system. ${ }^{54}$ While ministers in the Upper South and Border States showed more division and uneasiness with the endorsement of secession in the winter of 1860-1861, they agreed with their southern brethren on slavery's righteousness and the dangers of a majority that threatened the southern nationalist vision.

Thanksgiving and fast day sermons in the wake of the 1860 presidential election again placed educated men of standing throughout the South in a position to instill their views on the crisis in patriotic, moral, and religious terms. Southern clergy detailed their sectionalist vision as a national one and promoted proslavery republicanism in order to persuade their listeners that the true meaning of the Revolution and identity of America was in imminent danger. Like their northern counterparts, southern ministers understood that slavery was central to the crisis at hand and they similarly drew upon a shared legacy of the Revolution in order to justify their contentions. The sharp divide between the two sections, however, was on the conclusions drawn from that legacy. Northerners, albeit split on what to do about slavery, rallied behind a patriotic banner that defended popular government, liberty, and upholding the constitution. Elite southerners stood firmly entrenched in a defense of slavery and on the dangers that democracy posed to southern society. Of course, those dangers had the potential to come from within rather than just from the North, and southern ministers sought to impose their beliefs on southerners in order to prevent social upheaval.

Lincoln's election caused proslavery unionists to come to terms with the notion that securing slavery within the Union was no longer viable. As Mitchell Snay contends, the election triggered the final transformation from southern sectionalism to southern

\footnotetext{
${ }^{54}$ Snay, Gospel of Disunion, 155-156.
} 
nationalism. Indeed, hope for binding slavery to American nationalism appeared gone. ${ }^{55}$ Ministers now had to justify to their fellow southerners that even when considering secession, they were still upholding the true intentions of the constitution and the Founding Fathers. When Benjamin Palmer delivered a sermon after Calhoun's death in 1850 , he spoke of the dangers of democracy and the threats to the South's slave society; however, he still was a unionist and did not see secession as a viable course of action. Lincoln's election altered his decision and he used his Thanksgiving sermon in order to advocate for secession. Roughly 2,000 people in New Orleans filled the First Presbyterian Church to hear his sermon. Similar to many southern ministers, Palmer alleged he did not think that clergy should be political, and he condemned northerners for doing so. Yet, southern ministers did just that in their sermons by elevating the issues of secession and slavery above democratic politics and focusing on republicanism. Palmer claimed it was his purpose to "speak upon the question of the day; and to state the duty which, as I believe, patriotism and religion alike require of us all.” Just like northern clergy, Palmer and other southern ministers justified openly discussing the crisis to their congregants because of patriotic and religious duty. ${ }^{56}$

Palmer defended the institution of slavery through proslavery republicanism. He asserted that it was their duty as "constituted guardians" to protect the institution and placed it within a paternalistic framework by arguing that the slaves had the most to lose in this crisis because they needed their masters for protection. He claimed that God gave

\footnotetext{
${ }^{55}$ Snay, Gospel of Disunion, 151. This argument also concurs with Bonner's argument in Mastering America.

${ }^{56}$ B.M. Palmer, "Slavery a Divine Trust: Duty of the South to Preserve and Perpetuate It: A Sermon Preached in the First Presbyterian Church of New Orleans, LA., Nov. 29, 1860," in Fast Day Sermons, 6162. For other descriptions and analyses of Palmer's sermon, see: Snay, Gospel of Disunion, 175-180; Bonner, Ruling America, xi-xvii.
} 
southerners the responsibility of being guardians of the African race, which justified the protection of the institution on higher grounds than just an economic or social defense. All southerners had a duty under God with the institution of slavery. ${ }^{57}$ Andrew Lipscomb, chancellor of the University of Georgia, similarly justified his discussion of the crisis as a necessity in order for him to meet his responsibility during the state's day of fasting on November 28, 1860. "Were they party questions, you should not hear my voice," he told his listeners, elevating the present crisis above partisan politics. Lipscomb took part in a familiar process by eulogists to place important political issues outside the realm of political parties. Eulogists attempted to diminish partisans as legitimate voices in political debate since parties did not provide the desired answers to the issues. He strongly denounced northern criticism of slavery and delivered a passionate defense of the institution. According to Lipscomb, slavery benefited both whites and blacks, and the interests of humanity depended on its protection. He believed that slavery had international advantages as well, from the economic benefits to promoting "beyond computation the peace and prosperity of the world." Southern ministers, educators, and politicians resoundingly defended slavery on moral and religious terms. Not only did everyone benefit from slavery, but also God and the bible sanctioned it and gave whites the responsibility to care for slaves and uphold the institution. ${ }^{58}$

\footnotetext{
${ }^{57}$ Palmer, "Slavery a Divine Trust," in Fast Day Sermons, 65. Palmer's sermon was available and discussed throughout the North. It also drew parallels to northern proslavery clergymen such as Van Dyke. For comparison of the two sermons, see: "A Sermon in New Orleans," Columbian Register, January 5, 1861.

${ }^{58}$ Andrew A. Lipscomb, Substance of a Discourse Delivered Before the Legislature of Georgia, on the Occasion of the Fast-Day Appointed by his Excellency, Joseph E. Brown, November $28^{\text {th }}, 1860$ (Milledgeville: Boughton, Nisbet \& Barnes, 1860), 18, 19. For a study on proslavery rhetoric in the Antebellum South, see: Patricia Roberts-Miller, Fanatical Schemes: Proslavery Rhetoric and the Tragedy of Consensus (Tuscaloosa: The University of Alabama Press, 2009).
} 
Southern defenses of slavery were not surprising during the crisis. Slavery's portrayal as a positive good became a common strategy decades earlier. Lincoln's election, however, added a sense of urgency to calls for slavery's defense. The United States was a slaveholding republic since its inception, and slaveholders held prominent positions in government throughout all of American history up until that time. The Republican Party's impending control of the Executive Branch triggered a shift in the minds of southerners who saw the validity in antidemocratic warnings. The election signaled an end to southern hopes of imposing their sectionalist identity as a national one. The secession crisis elicited preaching about the downfalls of too much democracy and served as a warning for a future Confederate nation. Palmer placed the blame for the crisis solely on the North. When reviewing the Election of 1860 in his sermon, he declared that the North had "cast their ballot for a candidate who is sectional, who represents a party that is sectional, and the ground of that sectionalism, prejudice against the established constitutional rights and immunities and institutions of the South.” To Palmer and other elite southerners, the election represented more than frustration over a lost election. Their concern lay more deeply with a fundamental concern over democracy to preserve their desired vision for southern society. ${ }^{59}$

Warnings delivered by southern eulogists during the last two decades about the dangers of a plurality seemed to be coming to fruition. Northerners had voted for a man whom southerners perceived to be hostile to their vision of America. Palmer continued to look at the concept of democracy, and took issue with rebuttals that Lincoln was chosen

\footnotetext{
${ }^{59}$ Palmer, "Slavery a Divine Trust," in Fast Day Sermons, 71. Some secession eulogists continued argued that God was punishing the nation because of too much nationalist spirit. For those sentiments, see: C.C. Pinckney, Nebuchadnezzar's Fault and Fall: A Sermon, Preached at Grace Church, Charleston, S.C., on the $17^{\text {th }}$ of February, 1861 (Charleston: A.J. Burke, 1861), 10-11.
} 
by a fair majority. "But need I say, to those who have read history, that no despotism is more absolute than that of an unprincipled democracy, and no tyranny more galling than that exercised through constitutional formulas?" he asked his audience. The crisis was akin to that of the Revolution, except now he contended patriotic southerners were rebelling against a tyrannical majority rather than a king. ${ }^{60}$ Reverend William Prentiss of Charleston likewise equated the Republican Party with corruption. The values they stood for threatened southern life, and most notably slavery according to Prentiss, who used much of his sermon to give a biblical defense of the institution. "We seek no vengeance for past injury and insult; but we will not link our destiny with theirs," he asserted, continuing to note the crime and anarchy which inevitably followed the beliefs and democratic leanings of those in the North. ${ }^{61}$

Southern ministers argued that they were preserving the true intention of the Revolution. Just like northerners, southerners interpreted secession during the crisis through the lens of the Revolutionary legacy. In order to sell secession, ministers throughout the South had to convince their listeners that majority rule and antislavery rhetoric threatened the true meaning of the Revolution and the republic the Founders envisioned. "In less than a century we have spoiled the legacy of our fathers," lamented James Thornwell during his fast day sermon. Thornwell asserted that the government was always a compact of sovereign states, and likened the alliance of states to that of a treaty. It was the North, he claimed, that had sectional ambitions that threatened the Union. Like Palmer, Thornwell argued that the democratic shift was not the intended course for the

\footnotetext{
${ }^{60}$ Ibid., 72.

${ }^{61}$ William O. Prentiss, A Sermon Preached at St. Peter's Church, Charleston by the Rev. William O. Prentiss, on Wednesday, November 21, 1860, being a day of Public Fasting, Humiliation, and Prayer (Charleston: Evans \& Cogswell, 1860), 17.
} 
nation and endangered liberty and social stability. The purpose of representative assembly, he argued, was "not to ascertain what the will of the people actually is, but what it ought to be." He continued to note, "The people are not permitted to legislate en masse, because their passions and caprices are likely to prove stronger than reason and truth." Thornwell's damning critique of democracy was rooted in traditional republican notions held by elite men during the Revolutionary era. He warned that parliamentary government was the most "perfect under heaven" because it avoided the despotism of a single will and of mobs, which would lead society into anarchy. ${ }^{62}$ Elite southerners grounded their proslavery, pro-secession ideals in Revolutionary republican rhetoric, but for them the secession crisis was a counter-revolution against the democratic impulse within the nation. Many of Thornwell's critiques of democracy were similar to concerns voiced by northern eulogists throughout the antebellum era. Yet, the differing views over the legitimacy of Lincoln's election by plurality vote showed the ideological divide on representative government between northerners and southerners on the eve of the Civil War. $^{63}$

Southern ministers mirrored their northern counterparts by placing blame for the secession crisis on aspects of democratic political culture. Ministers, who viewed themselves as detached from the demagoguery that they railed against, targeted partisanship as being antagonistic to serious republicanism. Reverend George H. Clark's fast day sermon delivered in Savannah condemned antislavery northerners who fell

\footnotetext{
62 Thornwell, "Our National Sins," in Fast Day Sermons, 28, 39.

${ }^{63}$ There is a growing debate among historians about the extent to which secession was a counterrevolution. James McPherson describes it as such in The Battle Cry of Freedom and perhaps the strongest case for it being one is Manisha Sinha's The Counter-Revolution: Politics and Ideology in Antebellum South Carolina (Chapel Hill: University of North Carolina Press, 200). Michael Bernath's “The Confederacy as a Moment of Possibility," however, shows that for some, the confederacy offered an opportunity for significant social and political change.
} 
victim to "unscrupulous politicians and by ignorant demagogues" who trampled on the constitution and the wisdom of the Founding Fathers. The true sectional antagonists were antislavery northerners, claimed Clark. He viewed southerners as the last hope to save the Union. Democracy led to a "great majority of voters" to fall victim to the urgings of politicians on the slavery issue. ${ }^{64}$ Presbyterian Reverend R.K. Porter of Waynesboro, Georgia, echoed the sentiments of Palmer, Thornwell, and Clark. While he acknowledged the nation was a government of "the people," he reminded his listeners that the nation was not a pure democracy but a representative government, and that government was a voluntary agreement by the states. "Ours is not a government of the masses, or of an unbridled majority, but of a Constitution," exclaimed Porter who contended that if the compact failed to protect southerners' property rights - the foundation of proslavery republicanism—it was null and void. ${ }^{65}$

For decades, the vast majority of southerners had fervently defended slavery, yet secession over the issue did not happen until 1860-1861. Ministers reinforced slavery's importance and righteousness in sermons during the crisis, but another important goal was to persuade their listeners that majority rule was a grave threat to the proslavery republican ideology that they carried on from the Revolution. "But a vast region of the country, a controlling majority of States, a majority to be annually increased," Porter maintained, was set in defiance of the law and the spirit of free government. Porter reprimanded northerners beyond their votes for Lincoln in the Election of 1860. Lincoln's election troubled Porter, but it was its broader significance that placed the

\footnotetext{
${ }^{64}$ George C. Clark, The Union: A Sermon, Delivered in St. John's Church, Savannah, on Fast Day, Nov. 28, 1860 (Savannah: Geo. N. Nichols, 1860), 1, 13.

${ }^{65}$ R.K. Porter, Christian Duty in The Present Crisis: The Substance of a Sermon Delivered in The Presbyterian Church, in Waynesboro, Georgia (Savannah: John M. Cooper, 1860), 8.
} 
South in peril. He viewed Lincoln as a puppet of greater forces at work in the North. "Destroy him, and a thousand like him, and yet another, and again another would rise to be the embodiment of those same principles," asserted Porter, who deduced that, "the heart and conscience of the North is against us." Porter portrayed the North as being hopelessly dissimilar from the South. Corrupt politicians and a "religious element" that promoted abolitionism and the "thousand other monsters" that were its offspring threatened the South, justifying secession. His sermon also illuminated a divergence from northerners on conceptions of liberty. To Porter, the North's unrighteous infidelity and "licentious despotism of unbridled masses" was against "justice, law, and regulated liberty." His reference to regulated liberty, a concept dating back to the Puritans, illustrates a subtle difference between his sermon and those given throughout the North. Southerners such as Porter still used the Revolution's legacy, yet promoted a regulated form of liberty, which thus gave sanction to elite southerners to wage a counterrevolution. ${ }^{66}$

Clergy in the Upper South largely echoed Lower South ministers regarding support of slavery and concerns of democracy, yet diverged on whether secession was the proper path. Andrew H. H. Boyd praised God for the system of government the nation possessed when he preached to his Loudoun Street Presbyterian Church in Winchester. He continued to discuss the sins that caused such angst within the nation. Boyd warned of the "undue predominance of the spirit of party," which threatened the country. He criticized "political partizans" and the party controlled press while connecting the rise of partisanship with the decline of republicanism. The press became an engine of assault upon private character, which he argued hindered manly debate. "This is an evil that

\footnotetext{
${ }^{66}$ Porter, Christian Duty in The Present Crisis, 16.
} 
prevails in the land; and it becomes every one, whatever may be his political sentiments, to discountenance the exhibition of a disposition so unbecoming a high-minded and intelligent community," Boyd surmised to his congregation. ${ }^{67}$ Fellow Virginian, Robert Dabney, shared similar concerns about democratic political culture. His sermon, The Christian's Best Motive for Patriotism, reflected the divided sentiments of the region and saw the causes of the crisis similarly to Boyd. Party strife caused much of the national ills, according to Dabney. He called on each Christian citizen to "have his independent political predilections, and support them with decision.” Political affiliations were not necessarily corrupt and sinful, but a devotion to political parties and suppression of independent thought harmed the republic. Citizens were free to have moderate allegiance to a party, but "when their party demands of them that they shall sustain men of corrupt private morals or reckless passions," then Christians must reject the allegiance and recognize their relationship with God and his intentions. ${ }^{68}$

For Boyd and Dabney, sectionalism was another sin that went hand-in-hand with party strife, and sermons exhibited the precarious position in which the Border States found themselves during the crisis. Boyd echoed clergy in the Lower South in denouncing abolitionism and the results of the Election of 1860, and agreed that secession could be justifiable if fanaticism threatened slavery and other constitutional rights. Southern extremists, however, also deserved blame for sectional threats, and those who threatened the Union for "trivial causes" deserved rebuke as well. He contended that

\footnotetext{
${ }^{67}$ A.H. Boyd, Thanksgiving Sermon, Delivered in Winchester, VA. on Thursday, $29^{\text {th }}$ November, 1860 (Winchester: Winchester Virginian, 1860), 10, 11. For a strong rebuke of disunion from a slaveholding state, see: Robert J. Breckinridge, "The Union to be Preserved: A Discourse Delivered at Lexington, KY., on the Day of the National Fast, Jan. 4, 1861," in Fast Day Sermons, 98-126.

${ }^{68}$ Robert L. Dabney, "The Christian's Best Motive for Patriotism: A Sermon Preached in the College Church, Hampden Sidney, VA., on a General Fast Day, November 1, 1860," in Fast Day Sermons, 91.
} 
the Founding Fathers promoted the country's welfare in every section, and the country had allowed sectional desires to pervert from that mindset. ${ }^{69}$ Dabney also took issue with southern politicians in his sermon. He preached that "the reckless and incapable men whom you have weakly trusted with power or influence," were leading the nation to calamity. He criticized the violent nature of southern society, and alluded to the caning of Charles Sumner in the Senate in 1856 and the subsequent justification by "Southern secular prints, directed by reckless boys, or professed duelists," while decent southern men rightfully denounced the attack. Dabney shared the sentiments of many civilians in the Border States that upheld the legality and virtue of slavery, yet condemned the disunionists of the Lower South for instigating a bloody war and the dissolution of the Union. Ultimately, once Virginia secession became a reality after Lincoln's call for militia, Dabney evolved into a secessionist and became a Confederate chaplain during the war. $^{70}$

The indication that majority rule inevitably threatened the power structure in the South caused clergy and southern elites to accept secession. By condemning the North's use of the pulpit for fanatical and political purposes, clergy in the Lower South justified their discussion of the same topics by elevating secession and the crisis to a religious concern. The pulpit became an effective platform to convince southerners that their republican heritage was threatened and that secession was a necessary and patriotic course of action to assuage those dangers. R.K. Porter maintained that it was not for him to say "when, how, and by what means, the emergency shall be met," however, he almost immediately contradicted himself, asserting, "But done it must be, and speedily. We

\footnotetext{
${ }^{69}$ Boyd, Thanksgiving Sermon, 15, 12.

${ }^{70}$ Dabney, "The Christian's Best Motive for Patriotism," in Fast Day Sermons, 94, 95. For more on Dabney, see: Snay, Gospel of Disunion, 201-202.
} 
cannot let the waves overwhelm us." Porter recused himself from his political endorsement of secession. While he did not call for secession, he nonetheless demanded immediate action and used his sermon to indicate the dangers that southern society faced from the North, which he argued was solidly against them. ${ }^{71}$ Andrew Lipscomb believed that it was time to settle the conflict between free and slave states. He mourned the breakup of the Union. He concluded his sermon with admiration for the founding generation and the constitution, yet claimed if southerners could not have the constitution followed, then as free men and Christians they had a duty to "establish such a government as we need., 72

Mourning for the Union while simultaneously advocating for disunion made secession appear less radical and unlawful. ${ }^{73}$ By framing it as a way to preserve a cherished tradition, they could portray the North as the aggressors who threatened the true intentions of the nation. Palmer's Thanksgiving sermon that vehemently criticized democracy and defended slavery placed the issue onto the manhood and patriotism of southerners. "If the South bows before this throne," he warned, "she accepts the decree of restriction and ultimate extinction, which is made the condition of her homage." He warned they could not stand idly by while Lincoln took office and subsequently destroyed southern society. Palmer displayed the transition from southern sectional nationalist identity to a new form of southern nationalism. He urged his listeners to put their trust in the hands of great men of the South to take the necessary steps for framing a

\footnotetext{
${ }^{71}$ Porter, Christian Duty in the Present Crisis, 19.

${ }^{72}$ Lipscomb, Substance of a Discourse, 20.

${ }^{73}$ For an excellent study examining emotion and southerners mourning for the Union, see: Michael Eugene Woods, "The Heart of the Sectional Conflict: Emotion, Politics, and the Coming of the Civil War," Ph.D. diss., University of South Carolina, 2012. Woods argues that grieving for the Union helped turn reluctant secessionists into loyal confederates.
} 
"new and homogeneous confederacy." "74 James Thornwell shared Palmer's evolution from proslavery unionist to advocate of secession. He argued the Union was a compact under God, and if broken, then it should be dissolved. Despite his unionist inclinations, Thornwell lamented that the North had done just that. Nonslaveholding states broke that compact and "justified their course upon the plea of conscience." He reminded his listeners that they had important duties and standards under God to follow in relation to slavery. Ultimately, Thornwell believed the system was the best solution to the societal upheaval that he had long feared. Aspects of democracy threatened that stability, and he came to see disunion as the only way to preserve his antidemocratic nationalist vision. ${ }^{75}$ Northern and southern members of the eulogizing class shared a disdain for the hyper-partisanship and influence of politicians, yet by 1860 , the southern eulogists more aggressively continued to put faith in a virtuous few. Northerners still spoke out against the ill effects of a democratic government, yet when faced with the prospect of southern secession, they now supported majority rule and ministers began to place faith in "the people" during crisis. Southern clergy, meanwhile, still put more emphasis in the need for great men. Thornwell echoed Palmer's call to put faith in the hands of a few elite. He surmised that "If ever there was a time," since creation of the constitution when the country needed the "counsel and guidance of patriotic statesmen, it is now, when, under the lead of demagogues, factions and politicians, we have corrupted every principle of our polity and brought the Government to the brink of dissolution." Despite his change of position on secession, Thornwell gave a discouraging prophecy for what it may bring. Even though he believed the cause just, their "path to victory may be through a baptism

\footnotetext{
${ }^{74}$ Palmer, "Slavery a Divine Trust," in Fast Day Sermons, 77.

${ }^{75}$ Thornwell, "Our National Sins," in Fast Day Sermons, 34-35.
} 
of blood." While South Carolina may suffer, he concluded that the most impressive teachers of mankind were those who had "sealed their lessons with their blood.",76

Grieving for the Union helped its "eulogists" envision a new nation. Although R.K. Porter claimed he did not intend to detail the "sad times on which we have fallen," he nonetheless provided a clear glimpse into his interpretation of the crisis. "The blind see it, and the deaf hear it," he stated about the crisis at hand. Secession seemed inevitable, and he used his sermon to exert his opinion on the conflict to his listeners. The prospect of influential men discussing political issues in sermons and eulogies was not new in the winter of 1860-1861. Throughout the antebellum period, a eulogizing class spoke during times of national loss to influence "the people" in an attempt to direct the nation to fit their societal vision. Eulogizing was a significant political act in the two decades before the Civil War, and prominent members of society debated the changes deriving from the rise of democracy since the Jacksonian era. The complex understanding of the changes wrought by democracy, and just as importantly the changes in the ways eulogists understood democracy, had a significant influence on the eventual civil war throughout the nation. Eulogists came to be more at peace with their role in democratic discourse, even as some still opposed the excessive partisanship and fanaticism of democratic political culture. Those concerns ultimately shaped understandings of the events leading up to disunion as influential men attempted various forays into subduing the unsavory elements of an increasingly democratic form of government.

\footnotetext{
${ }^{76}$ Ibid., 55, 56. Several southern ministers echoed their northern counterparts in not believing war would be quick and bloodless. For another example, see: Thomas Atkinson, Christian Duty in the Present Time of Trouble. A Sermon Preached at St. James' Church, Wilmington, N.C., on the Fifth Sunday after Easter, 1861 (Wilmington: Fulton \& Price, 1861), 5.
} 


\section{Chapter 6:}

\section{Conclusion}

Abraham Lincoln's death at the hands of John Wilkes Booth sent the nation, still mourning over the destruction wrought by four years of civil war, into shock and uncertainty. Eulogists across the grief-stricken nation spoke of the tragedy and the significance of the country's loss in the days and weeks after his passing. Historian and public figure, George Bancroft, delivered a eulogy at Union Square in New York City, ten days after Lincoln died in the nation's capital. Bancroft had delivered eulogies before, for imposing figures like Andrew Jackson, who left a lasting impression on American politics and culture. Yet, Lincoln's death was unique in that he was the first president to die by assassination, and while the country celebrated the conclusion of the war, they now had to put back the pieces of a war-torn nation without the leader who directed the Union to victory. Bancroft's eulogy, similarly to eulogies delivered throughout the antebellum era, reflected his national vision and hopes for the country's future.

Freedom was the focal point of Bancroft's eulogy for Lincoln. The Civil War put to rest longstanding conflicts about the congressional balance of power between slave and free states and rid the country of a Slave Power that corrupted the government. Bancroft believed it was now time to look to the country's future by redefining the past. Slavery and its advocates became a peripheral institution in Bancroft's narrative of the country's history. Since the republic's inception, he contended, the leaders of the nation envisioned slavery gradually ending. "The constitutions of States had been transformed before the plotters of treason carried them away into rebellion," he claimed, and asserted that "When the Federal Constitution was framed, general emancipation was thought to be 
near." To Bancroft, slavery was an affront to the true intentions of the Founding Fathers, and Abraham Lincoln's emancipation of slaves during the war finally began a process of correcting a wrong that had tainted the nation since its inception. It was now up to Americans to ensure that traitors who were intent on continuing the institution of slavery did not undermine Lincoln's vision of universal freedom. ${ }^{1}$

The Civil War cleansed democracy of the institution that made it so odious to many eulogists during the antebellum era. With slavery on the road to extinction, democracy no longer would be affiliated with it, and America's leaders would not need to debate it any longer. Through Lincoln's election and subsequent reelection, citizens had determined that slavery was not in tune with American ideals, according to northern eulogists. Henry Bellows believed Lincoln transcended partisanship and had been "the head of the nation, and not the chief of a successful party." To Bellows, Lincoln was a great man who saw the nation through crisis by rallying a "million and a quarter of American citizens to arms in behalf of their flag and their Union," and touted Lincoln as "author of the Proclamation of Emancipation" and "the people's President." Despite the radical nature of emancipating over four million people in bondage, there were still attempts to downplay the radical nature of emancipation by some eulogists. ${ }^{2}$ Alonzo Quint praised Lincoln's achievements for both freedom and the Union and thought it necessary to place Lincoln's actions as in-step with the views of the nation. "When Abraham Lincoln was chosen President, the people said, by that choice, that slavery

\footnotetext{
${ }^{1}$ The Pulpit and Rostrums. Sermons, Orations, Popular Lectures, etc. (New York: Schermerhorn, Bancroft \& Co., 1865), 7. There is a more widely known oration on Lincoln delivered by Bancroft, which was delivered to Congress in 1866. For that address, see: George Bancroft, Memorial Address on the Life and Character of Abraham Lincoln (Washington, D.C.: Government Printing Office, 1866).

${ }^{2}$ Our Martyr President, Abraham Lincoln. Voice from the Pulpit of New York and Brooklyn (New York: Tibbals \& Whiting, 1865), 55-56.
} 
should not be extended," he reminded his listeners of the Republican Party platform during the Election of 1860. Southerners accused the Republicans of being extremists, but Quint re-directed the narrative by placing the Republicans as the defenders of American conservatism. "That party's sympathies were with freedom, but the platform was 'conservative,"' he claimed. He continued to remind his congregants that Lincoln did not begin the war with the intention of destroying slavery. "He was a conservative man. He felt bound by law not to interfere," believed Quint. Lincoln, just like the millions who fought for the Union, was a principled man who respected the law. ${ }^{3}$

The end of slavery marked a transitional moment for American democracy. Slavery heavily influenced the memorialization of national politicians and dictated perceptions of democracy. Throughout eulogies in the antebellum era, slavery repeatedly appeared as a topic that made democracy reprehensible to conservatives in particular-an idea reinforced by less-conservative eulogists (abolitionists and proslavery southerners). Conservatives perceived extremists as appearing to destabilize traditional republican society. Slavery's pervasion into the political issues of the day made democracy dangerous. But Lincoln's death was the beginning of a new era for politics. An army of over a million Union men had fought to reinforce the merits of democracy and forever end slavery in America.

For many Americans, reconstructing the war-torn nation became a primary concern and politicians found employing Lincoln's memory useful for political purposes. The eulogies delivered after Lincoln's assassination began a process of conceptualizing

\footnotetext{
${ }^{3}$ Alonso H. Quint, Three Sermons Preached in the North Congregational Church, New Bedford, Mass., Fast Day April 13, and Sunday, April 16, 1865 (New Bedford: Mercury Job Press, 1865), 25, 26. For more reactions from eulogists after the death of Lincoln, see: Carl Sandburg, Abraham Lincoln: The Prairie Years and the War Years One-Volume (New York: Harcourt, Brace and Company, 1954), 728-735.
} 
meanings of freedom, democracy, and conservatism, which has continued into contemporary times. Lincoln's legacy remains a political tool used by political parties and special interest groups seeking to validate their positions as American values. Since Lincoln's assassination, his career has sparked a wide range of emotions. While most eulogies and sermons mourned his tragic death, a minority of Americans, mostly hailing from the South, lauded Booth's actions and believed that Lincoln received just punishment for war crimes. Even today, some still condemn Lincoln as a tyrant who committed war crimes and ushered in an era of big and overreaching government. ${ }^{4}$ Lincoln's legacy has become engrained in American culture through memorials, symbols, political speeches, museums, and literature. ${ }^{5}$

The contested memories of political leaders have been significant in shaping America's political culture. During the antebellum era in particular, eulogizing was an important component to conceptualizations of democracy. With the nation's rapid expansion through the acquisition of new territories, the lingering memories of the Revolution intensified competing visions for national identity. When the death of a national figure brought the country into collective mourning, men of influence used their social positions to craft particular cultural narratives of the nation through the act of eulogy. The republican society envisioned during the Revolutionary era appeared to be fading away with the country's move toward egalitarianism. Elite white men used eulogies to create memories in a pursuit to maintain their influence in society, which seemed under threat. By praising the qualities of the "great man," eulogists cautioned

\footnotetext{
${ }^{4}$ For more information on anti-Lincoln sentiment, from during his career through the present times, see: John McKee Barr, Loathing Lincoln: An American Tradition from the Civil War to the Present (Baton Rouge: Louisiana State University Press, 2014).

${ }^{5}$ For more on the legacy of Abraham Lincoln and his influence on the Republican Party, see: Heather CoxRichardson, To Make Men Free: A History of the Republican Party (New York: Basic Books, 2014).
} 
against the democratic culture that gave increased power to political parties rather than the idealistic republican statesmen of the Revolutionary past.

Even though eulogists condemned the intensely partisan democratic political culture, they nonetheless, at times, were a part of democracy. George Bancroft, for example, fit within that mold. By the time of his eulogy for Andrew Jackson in 1845, he had become a well-known public figure. He was both a politician and historian, writing several volumes on the history of the United States and occasionally occupying political appointments. Although he spent the majority of his life as a Democrat, he neglected the role of political parties when writing the history of the United States. While it was unsurprising to Americans that he left out the role of parties due to the country's antiparty mindset, he nonetheless contributed to the democratic political culture that at times was deplored by eulogists. There was only room for the Democracy in his interpretation of America's past. As Jean Baker contends, Bancroft "was a majoritarian who had moved beyond antipartyism but who could not accept the possibility that party conflict contributed to republican society." Bancroft's contradictory relationship with the party system is emblematic of the relationship that many Americans had with the party system in the decades before the Civil War. Studying eulogies and sermons sheds light onto how Americans perceived the rise of the two-party system with Jacksonian Democracy. Historians too often are deceived by the high voter turnout and partisan nature of the antebellum era and overlook the strong undercurrents that carried on antiparty sentiments and fought against the party system.

\footnotetext{
${ }^{6}$ Jean H. Baker, Affairs of Party: The Political Culture of Northern Democrats in the Mid-Nineteenth Century (New York: Fordham University Press, 1998), 124.
} 
Studies on antebellum political culture have enriched our understanding of the political beliefs of many groups beyond traditional political figures, yet there is still more to uncover regarding thoughts about democracy throughout the era. As Americans debated issues concerning slavery, expansion, and representation, they were also debating the merits of democracy. The traditional influence of the elite was threatened when more white males gained the right to vote. Prominent Americans held deep reservations about democratic political culture and sought ways to prevent further changes by nostalgically looking backward to the past in order to preserve their vision for the future. From William Henry Harrison's death in 1841 through the mourning of the Great Triumvirate in the early 1850 s, eulogists created memories that encouraged their listeners to admire the republican example of the deceased "great men." And yet, there were changes in the ways eulogists understood democracy during the era. The secession crisis and the impending Civil War caused some eulogists to encourage "the people" to put those lessons from the past into practice and act in virtuous ways. Eulogists became more willing to accept their role in democratic discourse even as some still opposed democracy. Eulogies after Lincoln's death marked a new era as eulogists now conceptualized democracy liberated from the institution of slavery.

Eulogies, often viewed as apolitical by those who delivered them, were nonetheless a component of the combative democratic culture that the words of tribute often detested. Eulogists communicated antidemocratic beliefs through the means of the democratic culture, highlighting the tensions and contradictions inherent within American democracy. Even while eulogists condemned democratic political culture, they took part in it by talking to "the people" in order to convey their concerns. Democracy's dissenters 
often are overlooked in the rise of American democracy, but their resistance played an important part in the making of it. Eulogists used their orations of national leaders in an attempt to reinforce their perception of how politics was supposed to be, and to instill within their listeners a cultural narrative that sought to preserve the nation they had created through nostalgic memories. 


\section{Bibliography}

\section{Primary Sources}

A History of the Proceedings in the City of New Orleans on the Occasion of the Funeral Ceremonies in honor of Calhoun, Clay and Webster, Which Took Place on Thursday, December $9^{\text {th }}$, 1852. Published by order of the General Committee of Arrangements, on the Authority of the City Council. New Orleans: office of the Picayune, 1853.

Abbott, J. A Sermon Preached on the National Fast, May 14, 1841: Occasioned by the Death of William Henry Harrison. Salem: WM. Ives \& Co., 1841.

Adams, Nehemiah. A Sermon Preached to the Congregation at the Essex Street Church, October 31, 1852, the Sabbath after the Interment of Hon. Daniel Webster, by Nehemiah Adams, D.D., Pastor of the Essex Street church, Boston. Boston: Geo. C. Rand, Cornhill, 1852.

Allen, B.R. The Constitution and the Union: A Sermon Preached in the First Congregational Church in Marblehead, on the Occasion of the National Fast, January $4^{\text {th }}$ 1861. Boston: J.H. Eastburn's Press, 1861.

Allen, Joseph Henry. The Statesman and the Man: A Discourse on the Occasion of the Death of Hon. John Quincy Adams, Delivered in Washington, Feb 27, 1848. Washington: J. and G.S. Gideon, 1848.

Allen, William H. Eulogy on the Character and Services of the Late Daniel Webster, Pronounced at the Request of the Select and Common Councils of the City of Philadelphia, January 18, 1853. Philadelphia: Crissy \& Markley, Printers, Goldsmiths Hall, Library Street, 1853.

Americanus, Junius. A Review of "A discourse Occasioned by the Death of Daniel Webster, Preached at the Melodeon on Sunday, October 31, 1852, by Theodore Parker, Minister of the Twenty-Eighth Congregational Society in Boston." Boston: James Munroe and Company, 1853.

Anderson, Charles. A Funeral Oration, on the Character, Life, and Public Services of Henry Clay. Delivered in Cincinnati, Nov. 2, 1852, at the Request of the Clay Monumental Association of Ohio. Cincinnati: Ben Franklin Office Print, 1852.

Anspach, F.R. A Discourse Pronounced on Sabbath Evening, July 4, 1852, in the Lutheran Church of Hagerstown, on the Death of Henry Clay. Hagerstown: Mittag \& Sneary, 1852. 
Atkinson, Thomas. Christian Duty in the Present Time of Trouble. A Sermon Preached at St. James' Church, Wilmington, N.C., on the Fifth Sunday after Easter, 1861. Wilmington: Fulton \& Price, 1861.

Bancroft, George. Memorial Address on the Life and Character of Abraham Lincoln. Washington, D.C.: Government Printing Office, 1866.

Barnard, Daniel. Daniel Webster: Speech of Mr. Barnard [American Minister to Berlin] Delivered at a Meeting of Americans in Paris, on the $16^{\text {th }}$ of November 1852. Berlin: C. \& F. Unger, 1853.

Bates, Joshua. A Discourse on the Character, Public Services, and Death, of John Quincy Adams. Worchester: Samuel Chism, 1848.

Bellows, Henry W. The Valley of Decision: A Discourse given on the Occasion of the National Fast, Sept. 26, 1861, in All Souls' Church. New York: H.B. Price, 1861.

Benedict, A.D. Our Republic, a Brotherhood. A Discourse Delivered in St. John's Church, Delhi, N.Y., on the National Fast Day, Jan. $4^{\text {th }}$, 1861. Delhi, 1861.

Berrien, John MacPherson. Eulogy on the Life and Character of William Henry Harrison, Late President of the United States: Delivered Before the Citizens of Savannah, in the Independent Presbyterian Church, on Wednesday, May $12^{\text {th }}$, 1841. Savannah: W.T. Williams, 1841.

Boyd, A.H. Thanksgiving Sermon, Delivered in Winchester, VA. on Thursday, $29^{\text {th }}$ November, 1860. Winchester: Winchester Virginian, 1860.

Bucher, T.P. Union National Fast Day Sermon, Delivered in the United Presbyterian Church, Gettysburg, PA, Friday, January 4, A.D. 1861. Gettysburg: H.C. Neinstedt, 1861.

Bulkley, Edwin A. Wars and Rumors of Wars: A Sermon Preached at the Union Church in Groton, Mass, on Sunday, April 21 ${ }^{\text {st }}$, 1861. Cambridge: Miles and Dillingham, 1861.

Butler, C.M. "A Wise Man is Strong.” A Sermon on the Death of Daniel Webster, Delivered in Trinity Church, Washington, D.C., November 7, 1852. Washington: W.M. Morrison \& Co., 1852.

Carpenter, Hugh S. Eulogy on the Late William Henry Harrison, President of the United States; Delivered Before the Eucleian Society of the University of the City of New-York, May 28, 1841. New York: Hopkins \& Jennings, 1841. 
Chadbourne, John S. The Mortal and the Immortal: A Sermon, Preached in St. James; Church, Baton Rouge, in Improvement of the Character and Death of the Hon. Henry Clay. New Orleans: Picayune, 1852.

Clark, George C. The Union: A Sermon, Delivered in St. John's Church, Savannah, on Fast Day, Nov. 28, 1860. Savannah: Geo. N. Nichols, 1860.

Crane, William Carey. A Discourse Occasioned by the Death of William Henry Harrison President of the United States, delivered May 2, 1841, in the Baptist Church. Montgomery: Montgomery Advertiser, 1841.

Cuyler, Cornelius C. The Signs of the Times: Series of Discourses delivered in the Second Presbyterian Church, Philadelphia. Philadelphia: William S. Martien, 1839.

Damon, Norwood. The Holy Voice. A Discourse, Delivered Before the Society of the Rev. David Damon, in the West Cambridge, Mass. On Friday, May 14, 1841, The Day of the National Fast, Appointed in Consequence of the Death of William Henry Harrison, President of the United States. Boston: Charles C. Little and James Brown, 1841.

Dewey, Orville. On Patriotism: The Condition, Prospects, and Duties of the American People, a Sermon delivered on Fast Day at Church Green, Boston. Boston: Ticknor and Fields, 1859.

Doggitt, David S. A Sermon on the Occasion of the Death of General William Henry Harrison, Late President of the United States, Delivered in the Chapel of Randolph Macon College, April 18, 1841. Richmond: The Christian Advocate, 1841.

Douglass, Jacob. A Discourse on the Death of General Harrison, Late President of the United States, Preached in St. Mathews Church, Francisville, Philadelphia, on Sunday, $18^{\text {th }}$ April 1841, by the Rev. Jacob M. Douglass. Philadelphia: printed by H. Probasco, 1841.

Duffield, George. Our National Sins to be Repented of, and the Grounds of Hope for the Preservation of our Federal Constitution and Union: A Discourse Delivered Friday, January 4, 1861, on the Day of Fasting, Humiliation and Prayer Appointed by the President of the United States. Detroit: Free Press Mammoth Book and Job Printing, 1861.

Dusenbury, B.M. ed. Monument to the Memory of General Andrew Jackson: Containing Twenty-Five Eulogies and Sermons Delivered on the occasion of his Death. Philadelphia: Walker \& Gillis, 32 South Fourth Street, 1846. 
Everett, Edward. A Eulogy on the Life and Character of John Quincy Adams, Delivered at the Request of the Legislature of Massachusetts, in Faneuil Hall. Boston: Dutton and Wentworth, State Printers, 1848.

Farley, Frederick A. A Discourse on the Life and Character of John Quincy Adams, preached at the Church of the Savior, on Sunday Evening, March 4, 1848. Brooklyn: Lees \& Foulkes, 1848.

Fast Day Sermons: or the Pulpit on the State of the Country. New York, Rudd \& Carleton, 1861.

Fiske, John O. A Sermon on the Present National Troubles, Delivered in the Winter Street Church, January 4, 1861, the Day of National Fast. Bath: The Daily Times Office, 1861.

Furness, W.H. A Sermon Delivered May 14, 1841, On the Occasion of The National Fast Recommended by the President. Philadelphia: John C. Clark, 1841.

Furness, William Henry. The Memory of the Just. A Discourse, Delivered in the First Congregational Unitarian Church, in Philadelphia, February 27, 1848. Philadelphia: Crissy and Markley, 1848.

Goodrich, William H. A Sermon, on the Christian Necessity of War. Cleveland: Fairbanks, Benedict \& Co., 1861.

Greene, William. An Oration on the Life and Character of John Quincy Adams, Delivered at Cincinnati, 25 March, 1848, Before the Bar of Hamilton County, at their Request. Cincinnati: Cincinnati Chronicle, 1848.

Hague, William. A Discourse Occasioned by the Death of the Hon. John Quincy Adams, Delivered in the Rowe Street Baptist Church, February 27, 1848. Boston: William D. Ticknor \& Company, 1848.

Hanks, Stedman W. A Sermon on the Occasion of the Death of the Hon. John Quincy Adams, Preached at the John Street Congregational Church, in Lowell, March 5, 1848. Lowell: W.H. Waldron, 1848.

Hawthorne, Nathaniel. Life of Franklin Pierce. Boston: Tickner, Reed, and Fields, 1852.

Hitchcock, Roswell D. A Eulogy on Daniel Webster, Delivered Before the Students of Bowdoin College, on Friday, Nov. 12 ${ }^{\text {th }}$, 1852. Brunswick: J. Griffin, 1852.

Hoffman, Ogden. Oration of Ogden Hoffman, United States District Judge, at the Celebration of the Obsequies of Henry Clay, by the Citizens of San Francisco, California, August 10 ${ }^{\text {th }}$, 1852, and the Proceedings of the United States Court on 
the Reception of the Mournful Intelligence of his Death. New York: Daniel Fanshaw, 1852.

Hovey, Horace C. The National Fast: A Sermon, Preached at Coldwater, Mich., January 4, 1861. Coldwater: Republican Print, 1861.

Humphrey, Heman. Our Nation: A Discourse Delivered at Pittsfield, Mass., January 4, 1861, on the Day of National Fast. Pittsfield: Henry Chickering, 1861.

Johnson, Herschel V. Oration on the Life and Character of Andrew Jackson. Milledgeville, 1845.

King, Charles. Eulogy upon John Quincy Adams, Prepared at the Request of the Corporate Authorities of the Borough of Elizabeth, and Delivered Before Them, on Wednesday Evening, April 5 ${ }^{\text {th }}$, 1848. Elizabethtown: E. Sanderson, 1848.

King, Thomas Starr. The Death of Mr. Webster: A Sermon Preached in Hollis-Street Meeting-House, on Sunday, Oct. 31, 1852. Boston: Benjamin H. Greene, 1852.

Labaree, Benjamin. A Sermon on the Death of General Harrison, Delivered in Middlebury, Vermont, on the Day of the National Fast. Middlebury, E.Maxham, 1841.

Leakin, Geo. A. A Sermon on the Death of Henry Clay; Preached in Trinity Church, Baltimore, on $7^{\text {th }}$ Sunday after Trinity, 1852, by Rev. Geo. A. Leakin, A.M. Baltimore: A.P. Burt, 1852.

Lipscomb, Andrew A. Substance of a Discourse Delivered Before the Legislature of Georgia, on the Occasion of the Fast-Day Appointed by his Excellency, Joseph E. Brown, November 28 $8^{\text {th }}$, 1860. Milledgeville: Boughton, Nisbet \& Barnes, 1860.

Livermore, A.A. A Discourse Preached on the Occasion of the Death of Hon. John Quincy Adams, to the Unitarian Church and Congregation, Keene, N.H. on the Sabbath Afternoon, March 5, 1848. Keene: J.W. Prentiss \& co., 1848.

Lord, C.E. Sermons on the Country's Crisis, Delivered in Mount Vernon, N.H., April 28, 1861. Milford: Boutwell's Newspaper, 1861.

Lord, John C. Causes and Remedies of the Present Convulsions: A Discourse. Buffalo: Joseph Warren \& Co., 1861.

Lord, Nathan. A Eulogy of the Honorable John Quincy Adams, Delivered March 24, 1848, at the Request of the Students of Dartmouth College. Hanover: Dartmouth Press, 1848. 
Lunt, William P. A Discourse Delivered in Quincy, March 11, 1848, at the Interment of John Quincy Adams. Boston: Dutton and Wentworth State Printers, 1848.

Mayo, A.D. A Sermon on Daniel Webster, preached at Gloucester, Mass. Gloucester: John S.E. Rogers, 1852.

McGill, Alexander T. The Presence of God a People's Prosperity: A Sermon Preached on Sunday Morning, April 11, 1841, in the Presbyterian Church, at Carlisle, PA. Philadelphia: William S. Martin, 1841.

Mercer, Alexander G. American Citizenship, - Its faults and their Remedies: A Sermon for the Day of National Fast, January 4, 1861. Boston: Little, Brown and Company, 1861.

M'Jilton, J.N. God's Footsteps: A Sermon delivered in St. Stephen's Church, Baltimore, July $4^{\text {th }}$, 1852, the Sunday Succeeding the Death of Hon. Henry Clay. Baltimore: G.W. Magers, 1852.

Niven, John, ed. The Salmon P. Chase Papers Volume II: Correspondence 1823-1857. Kent: Kent State University Press, 1994.

Our Martyr President, Abraham Lincoln. Voice from the Pulpit of New York and Brooklyn. New York: Tibbals \& Whiting, 1865.

Parker, Theodore. A Discourse Occasioned by the Death of Daniel Webster, Preached at the Melodeon on Sunday, October 31, 1852. Boston: Benjamin B. Musey \& co., 1853.

Parker, Theodore. A Discourse Occasioned by the Death of John Quincy Adams, Delivered at the Melodeon in Boston, March 5, 1848. Boston: Bela Marsh, 1848.

Parsons, Benjamin. Eulogy on the Private and Public Character, and Public Services of the Late President Harrison. Pensacola, 1841.

Perley, Ira. Eulogy of the Hon. Ira Perley, on the Late Daniel Webster, pronounced before the Executive and Legislative Departments of New Hampshire, December 22, 1852. Concord: Butterfield \& Hill, State Printers, 1852.

Perry, A.F. Eulogy on the Life and Character of John Quincy Adams, Delivered Before the Citizens of Columbus, Ohio, April 8, 1848. Columbus: Ohio Press, 1848.

Pinckney, C.C. Nebuchadnezzar's Fault and Fall: A Sermon, Preached at Grace Chuch, Charleston, S.C., on the $17^{\text {th }}$ of February, 1861. Charleston: A.J. Burke, 1861. 
Pope, Jr., Leroy. A Eulogy, Upon the Life and Public Services of Daniel Webster, by Leroy Pope, Jr., esq. Delivered at Memphis, Tenn., on the $28^{\text {th }}$ Feb., 1853. Memphis: Eagle and Enquirer Steam Printing House, 1853.

Porter, Charles S. A Discourse Occasioned by the Death of Wm. Henry Harrison, Delivered April 18 ${ }^{\text {th }}$, Repeated by Request, April 25 ${ }^{\text {th }}$, 1841. New York:

Chatterton \& Crist, 1841.

Porter, R.K. Christian Duty in The Present Crisis: The Substance of a Sermon Delivered in The Presbyterian Church, in Waynesboro, Georgia. Savannah: John M. Cooper, 1860.

Potter, Horatio. A Discourse on the Death of William Henry Harrison, Late President of the United States; Delivered Before the two Houses of the Legislature of the State of New-York, On the $25^{\text {th }}$ Day of April, 1841. Albany, New York, 1841.

Prentiss, William O. A Sermon preached at St. Peter's Church, Charleston by the Rev. William O. Prentiss, on Wednesday, November 21, 1860, being a day of Public Fasting, Humiliation, and Prayer, appointed to be delivered by the Legislature of the State of South Carolina, on contemplation of the Secession of the State from the Union. Charleston: Stean-Power, 1860.

Putnam, George. A Discourse, On the Occasion of the Death of William Henry Harrison, Ninth President of the United States: Delivered at Roxbury, April 16, 1841. Boston: William Crosby and co., 1841.

Quint, Alonzo H. The Christian Patriot's Present Duty: A Sermon Addressed to the Mather Church and Society, Jamaica Plain, Mass., April 28, 1861. Boston: Hollis \& Gunn, 1861.

Quint, Alonso H. Three Sermons Preached in the North Congregational Church, New Bedford, Mass., Fast Day April 13, and Sunday, April 16, 1865. New Bedford: Mercury Job Press, 1865.

Rawlings, Augustus. Eulogy on Daniel Webster, Delivered before the Students and Friends of the Albany Medical College. Friday, Oct. 28 $8^{\text {th }}$, 1852. Albany: J. Munsell, 58 State Street, 1852.

Richards, George. A Discourse, Occasioned by the Death of Daniel Webster, Delivered in Central Church, Boston, October 31, 1852. Boston: T.R. Martin, 1852.

Richardson, James D., ed., Messages and Papers of the Presidents, (20 vols., Washington, D.C., 1897-1917), I. 
Richardson, R.H. National Bereavements. A Discourse, Delivered in the North Presbyterian Church, of Chicago, on Thanksgiving Day, Nov. 25, 1852. Chicago: S.C. Griggs \& co., 1852.

Rudd, John C. Forgetfulness of God: A Sermon, Preached in Trinity Church Utica, on Friday, May 14, 1841, Being the Day Recommended by the President of the United States, as a Day of National Humiliation and Prayer. Utica: Horbart Press, 1841.

Ruchames, Louis ed., The Letters of William Lloyd Garrison, Volume II: A House Dividing Against Itself, 1836-1840. Cambridge: Harvard University Press, 1971.

Sampson, G.W. The Providence of God in Raising up under our Republican Institutions, Great and Good Men as our Rulers: A Discourse Delivered by Rev. G.W. Sampson, Pastor of the Baptist Church, Jamaica Plain, Mass., on Thanksgiving Day, Nov. 25, 1862. Boston: Ticknor, Reed, and Fields, 1852.

Shannon, Isaac. Divine Providence in American History and Politics: A Discourse Delivered in the Second Presbyterian Church, New-Brunswick, N.J., July 4, 1852. New-Brunswick: A. Ackerman, Publisher, 1852.

Sheppard, John H. An Eulogy Pronounced at Wiscasset, in the Afternoon of the State Fast, April 22d, 1841 on William Henry Harrison, Late President of the U.S. Delivered and Published at the Request of a Committee of the Citizens of Wiscasset. Wiscasset: R.B. Caldwell, 1841.

Skinner, Otis A. The Death of Daniel Webster: A Sermon, Delivered in the Warren Street Church, Sunday, November 14, 1852. Boston: A. Tompkins, 1852.

Smith, M.B. The Nation's Danger and the Nation's Duty: A Sermon, preached in St. John's Parish, Passaic, New Jersey, on Sunday Afternoon, April $21^{\text {st }}, 1861$. New York: John A. Gray, 1861.

Speech of Hon. George W. Woodward, Delivered at the Great Union Meeting in Independence Square, Philadelphia, December $13{ }^{\text {th }}$ 1860. Philadelphia: Age Office, 1863.

Spencer, Ichabod S. The National Warning: A Sermon, Preached on the Sabbath After the Death of General WM. H. Harrison, Late President of the United States. New York: John S. Taylor \& co., 1841.

Sprague, William. Voice of the Rod: A Sermon, Delivered at Albany, May 14, 1841, The Day of the National Fast, Occasioned by the Death of the Late William Henry Harrison, President of the United States. Albany: C. Van Benthuyser, 1841. 
The Adams Memorial; Containing a Sketch of John Adams, the Elder, Together With the Life, Character, Public Services, Last Sickness, Death, and Funeral Obsequies of the Late Venerable John Quincy Adams. Boston: J.B. Hall, 1848.

The Pulpit and Rostrums. Sermons, Orations, Popular Lectures, etc. New York: Schermerhorn, Bancroft \& Co., 1865.

Thomas, John Peyre. The Carolina Tribute to Calhoun. Columbia: R.L. Bryan, 1857.

Thompson, Joseph P. The President's Fast; A Discourse upon our National Crimes and Follies, Preached in the Broadway Tabernacle Church, January 4, 1861. New York: Thomas Holman, 1861.

Token of a Nation's Sorrow: Addresses in the Congress of the United States and Funeral Solemnities on the Death of John Quincy Adams. Washington: J and G.S. Gideon, 1848.

Tyler, Moses. Our Solace and Our Duty in this Crisis: A Sermon for the Last Night of Mr. Buchanan's Presidential Administration, preached in the First Congregational Church, Poughkeepsie, N.Y, on the Sabbath Evening, March 3d, 1861. Poughkeepsie: Flatt \& Schram, 1861.

Wadsworth, Charles. Our Own Sins: A Sermon Preached in the Arch Street Church, on the Day of Humiliation and Prayer, Appointed by the President of the United States, Friday, January $4^{\text {th }}$, 1861. Philadelphia: King \& Baird, 1861.

Walker, Timothy. An Oration on the Life and Character of John Quincy Adams: Delivered Before the Citizens of Cincinnati, On the Twenty-second day of March, 1848. Cincinnati: J.F. Desilver, 1848.

Wheeler, John. A Discourse Occasioned by the Death of Gen. William Henry Harrison, President of the United States, Delivered Before the Citizens of Burlington and Vicinity, April 23, 1841. Windsor: Chronicle Press, 1841.

Whitman, Walt. The People and John Quincy Adams. Berkeley Heights, Oriole Press, 1961.

Wilson, Joshua L., A Sermon, In Memory of the Death of William Henry Harrison, the Late President of the United States. Cincinnati: The Republican Office, 1841.

Newspapers/Journals/Periodicals:

Arkansas Whig

Ashtabula Weekly Telegraph

Belmont Chronicle

Chicago Daily Tribune 
Christian Observer

Christian Recorder

Columbian Register

Daily National Intelligencer

Democrat's Review

The District School Journal of the State of New York

Fayetteville Observer

Frederick Douglass' Paper

Gleason's Pictorial Drawing - Room Companion

Liberator

Littell's Living Age

Macon Telegraph

Massachusetts Common School Journal

Mississippian and State Gazette

New-Hampshire Patriot

New-Hampshire Sentinel

New Hampshire Statesman

New York Daily Times

New York Herald

North American and United States Gazette

Niles' National Register

Philadelphia Inquirer

Plough, the Loom and the Anvil

Portsmouth Journal of Literature and Politics

Richmond Whig

The American Whig Review

The Boston Daily Atlas

The Charleston Mercury

The Daily Cleveland Herald

The District School Journal of the State of New York

The North American and Daily Advertiser

The Pennsylvania Freeman

The Raleigh Register

The Southern Literary Messenger

The World

Weekly Herald

\section{Secondary Sources}

Altschuler Glenn C, and Blumin, Stuart M. Rude Republic: Americans and Their Politics in the Nineteenth Century. Princeton: Princeton University Press, 2000.

Anbinder, Tyler. Nativism and Slavery: The Northern Know Nothings and the Politics of the 1850s. New York: Oxford University Press, 1992. 
Appleby, Joyce. Inheriting the Revolution: The First Generation of Americans. Cambridge: Harvard University Press, 2000.

Ashworth, John. Slavery, Capitalism, and Politics in the Antebellum Republic: Volume 2, The Coming of the Civil War 1850-1861. New York: Cambridge University Press, 2007.

Ayers, Edward L. What Caused the Civil War: Reflections on the South and Southern History. New York: W.W. Norton \& Company, 2005.

Baker, Jean H. Affairs of Party: The Political Culture of Northern Democrats in the Mid-Nineteenth Century. Ithaca: Cornell University Press, 1983.

Barr, John McKee. Loathing Lincoln: An American Tradition from the Civil War to the Present. Baton Rouge: Louisiana State University Press, 2014.

Bartlett, Irving H. John C. Calhoun: A Biography. New York: W.W. Norton and Company, 1993.

Bartlett, Irving H. "Edward Everett Reconsidered," The New England Quarterly 69 (September 1996).

Beard, Charles and Mary, The Rise of American Civilization. New York: Macmillan, 1927.

Belohavek, John M. Broken Glass: Caleb Cushing and the Shattering of the Union. Kent: Kent State University Press, 2005.

Bernath, Michael T. "The Confederacy as a Moment of Possibility." The Journal of Southern History 79, 2 (May 2013).

Bishop, Charles C. “The Pro-Slavery Argument Reconsidered: James Henley Thornwell, Millennial Abolitionist" The South Carolina Historical Magazine 73, 1 (January 1972).

Benson, Lee. The Concept of Jacksonian Democracy: New York as a Test Case. Princeton: Princeton University Press, 1961.

Blue, Frederick J. No Taint of Compromise: Crusaders in Antislavery Politics. Baton Rouge: Louisiana State University Press, 2005.

Bonner, Robert E. Mastering America: Southern Slaveholders and the Crisis of American Nationhood. New York: Cambridge University Press, 2009.

Borrit, Gabor, ed. Why the Civil War Came. New York: Oxford University Press, 1996. 
Boulard, Garry. The Expatriation of Franklin Pierce: The Story of a President and the Civil War.New York, iuniverse, 2006.

Bowman, Shearer Davis. At The Precipice: Americans North and South During the Secession Crisis. Chapel Hill: University of North Carolina Press, 2010.

Brock, William R. Parties and Political Conscience: American Dilemmas 1840-1850. Millwood: KTO press, 1979.

Bromwich, David. The Intellectual Life of Edmund Burke: From the Sublime and Beautiful to American Independence. Cambridge: Harvard University Press, 2014.

Brundage, Fitzhugh, ed. Where These Memories Grow: History, Memory, and Southern Identity. Chapel Hill: University of North Carolina Press, 2000.

Burstein, Andrew: America's Jubilee. New York: Alfred A. Knopf, 2001.

Burstein, Andrew and Isenberg, Nancy, ed. Mortal Remains: Death in Early America. Philadelphia: University of Pennsylvania Press, 2003.

Carwardine, Richard J. Evangelicals and Politics in Antebellum America. Knoxville: University of Tennessee Press, 1997.

—. "Evangelicals, Whigs and the Election of William Henry Harrison." Journal of American Studies 17 (1983).

Cooper, William. The South and the Politics of Slavery 1828-1856. Baton Rouge: Louisiana State University Press, 1978.

Confino, Alon. "Collective Memory and Cultural History: Problems of Method," The American Historical Review 102, 5 (December 1997).

Cox-Richardson, Heather. To Make Men Free: A History of the Republican Party. New York: Basic Books, 2014.

Davis, William C. Jefferson Davis: The Man and His Hour. Baton Rouge: Louisiana State University Press, 1991.

Earle, Jonathan H. Jacksonian Antislavery and the Politics of Free Soil, 1824-1854. Chapel Hill: University of North Carolina Press, 2004.

Ellis, Richard E. The Union at Risk: Jacksonian Democracy, States Rights and the Nullification Crisis. New York: Oxford University Press, 1987. 
Ericson, David F. The Debate over Slavery: Antislavery and Proslavery Liberalism in Antebellum America. New York: New York University Press, 2000.

Etcheson, Nicole. Bleeding Kansas: Contested Liberty in the Civil War Era. Lawrence: University of Kansas Press, 2004.

Eyal, Yonatan. The Young America Movement and the Transformation of the Democratic Party, 1828-1861. New York: Cambridge University Press, 2007.

Faust, Drew Gilpin. James Henry Hammond and the Old South: A Design for Mastery. Baton Rouge, Louisiana State University Press, 1982.

- This Republic of Suffering: Death and the American Civil War. New York: Alfred A. Knopf, 2008.

- ed. The Ideology of Slavery: Proslavery Thought in the Antebellum South, 1830-1860. Baton Rouge, Louisiana Sate University Press, 1981.

Fellman, Michael. "Theodore Parker and the Abolitionist Role in the 1850s," The Journal of American History 61 (December 1974).

Foner, Eric. Free Soil, Free Labor, Free Men: The Ideology of the Republican Party before the Civil War. New York: Oxford University Press, 1970.

_ "The Causes of the American Civil War: Recent Interpretations and New Directions," Civil War History 20, 3 (September 1974).

Ford, Jr., Lacy K. Origins of Southern Radicalism: The South Carolina Upcountry, 1800-1860. New York: Oxford University Press, 1988.

—. "Republican Ideology in a Slave Society: The Political Economy of John C. Calhoun" The Journal of Southern History 54, 3 (August 1988).

Forgie, George B. Patricide in the House Divided: A Psychological Interpretation of Lincoln and his Age. New York: W.W. Norton \& Company, 1979.

Formisano, Ronald P. The Birth of Mass Political Parties: Michigan 1827-1861. Princeton: Princeton University Press, 1971.

—. "Political Character, Antipartyism, and the Second Party System." American Quarterly 21, 4 (Winter 1969).

Fox-Genovese, Elizabeth. The Mind of the Master Class: History and Faith in the Southern Slaveholders' Worldview. New York: Cambridge University Press, 2005. 
Fraser Steve and Gerstle, Gary, eds., Ruling America: A History of Wealth and Power in Democracy. Cambridge: Harvard University Press, 2005.

Freehling, William W. Prelude to Civil War: The Nullification Crisis in South Carolina, 1816-1836. New York: Harper and Row, 1966.

—. The Road to Disunion: Secessionists at Bay 1776 1854. New York: Oxford University Press, 1990.

- The Road to Disunion, Volume II: Secessionists Triumphant. New York: Oxford University Press, 2007.

—. "James Henley Thornwell's Mysterious Antislavery Moment" The Journal of Southern History 57, 3 (August 1991)

Frothingham, Paul Revere. Edward Everett. Boston: Houghton Mifflin, 1925.

Gallagher, Gary. The Union War. Cambridge: Harvard University Press, 2011.

Garra, Larry. The Presidency of Franklin Pierce. Lawrence: University of Kansas Press, 1991.

Geffen, Elizabeth M., "William Henry Furness: Philadelphia Antislavery Preacher," The Pennsylvania Magazine of History, 82 (1958).

Gienapp, William E. The Origins of the Republican Party, 1852-1856. New York: Oxford University Press, 1986.

Ginzberg, Lori. Untidy Origins: A Story of Woman's Rights in Antebellum New York. Chapel Hill: University of North Carolina Press, 2005.

Grant, Susan-Mary. North over South: Northern Nationalism and American Identity in the Antebellum Era. Lawrence: University Press of Kansas, 2000.

Greenberg, Amy S. A Wicked War: Polk, Clay, Lincoln and the 1846 U.S. Invasion of Mexico. New York: Knopff, 2013.

- Manifest Manhood and the Antebellum American Empire. Cambridge: Cambridge University Press, 2005.

—. "The Politics of Martial Manhood" Common-Place, vol. 9., no. 1., 2008. Accessed on 9/1/10.

Guelzo, Allen C. Lincoln and Douglas: The Debates that Defined America. New York: Simon and Schuster, 2008. 
Gunderson, Robert Gray. The Log-Cabin Campaign. Lexington: The University of Kentucky Press, 1957.

Halttunen, Karen. Confidence Men and Painted Women: A Study of Middle-Class Culture in America, 1830-1870. New Haven: Yale University Press, 1982.

Hamilton, Holman. Prologue to Conflict: The Crisis \& Compromise of 1850. Lexington: University of Kentucky Press, 1964.

Hatch, Nathan O. The Democratization of American Christianity. New Haven: Yale University Press, 1989.

Henderson, Timothy J. A Glorious Defeat: Mexico and its War with the United States. New York: Hill and Wang, 2007.

Hess, Earl. J. Liberty, Virtue, and Progress: Northerners and their War for the Union. New York: Fordham University Press, 1997.

Hessinger, Rodney. Seduced, Abandoned, and Reborn: Visions of Youth in MiddleClass America, 1780-1850. Philadelphia: University of Pennsylvania Press, 2005.

Hofstadter, Richard. The Idea of a Party System: The Rise of Legitimate Opposition in the United States, 1780-1840. Berkeley: University of California Press, 1969.

Holden, Charles J. In the Great Maelstrom: Conservatives in Post-Civil War South Carolina. Columbia: University of South Carolina Press, 2002.

Holt, Michael F. The Rise and Fall of the American Whig Party: Jacksonian Politics and the Onset of the Civil War. New York: Oxford University Press, 1999.

- The Political Crisis of the 1850s. New York: W.W. Norton \& company, 1978.

Howe, Daniel Walker. The Political Culture of the American Whigs. Chicago: The University of Chicago Press, 1979.

—. "The Evangelical Movement and Political Culture during the Second Party System.” Journal of American History, 77. (1991).

Voss-Hubbard, Mark. Beyond Party: Cultures of Antipartisanship in Northern Politics Before the Civil War. Baltimore: Johns Hopkins University Press, 2002.

Johnson, Paul E._A Shopkeeper's Millennium: Society and Revivals in Rochester, New York, 1815-1837. New York: Hill and Wang, 1978. 
Kraut, Alan M. ed. Crusaders and Compromisers: Essays on the Relationship of the Antislavery Struggle to the Antebellum Party System. Westport: Greenwood Press, 1983.

Kruman, Marc W., "The Second American Party system and the Transformation of Revolutionary Republicanism," Journal of the Early Republic 12 (1992).

Larson, Mark J. "A Champion of the Original American Republic: The Political Thought of James Thornwell," The Journal of Presbyterian History 82, 4 (winter 2004).

Lawson, Melinda. Patriot Fires: Forging a New American Nationalism in the Civil War North. Lawrence: University Press of Kansas, 2002.

Benedict R. Maryniak and Benedict, Brinsfield John Vesley, eds., The Spirit Divided: Memoirs of Civil War Chaplains: The Union. Macon: Mercer University Press, 2007.

McCormick, Richard P. The Second American Party System: Party Formation in the Jacksonian Era. Chapel Hill: University of North Carolina Press, 1966.

McCurry, Stephanie. Masters of Small Worlds: Yeoman Households, Gender Relations, \& the Political Culture of the Antebellum South Carolina Low Country. New York: Oxford University Press, 1995.

McDaniel, Caleb W. The Problem of Democracy in the Age of Slavery: Garrisonian Abolitionists \& Transatlantic Reform. Baton Rouge: Louisiana State University Press, 2013.

McPherson, James M. Battle Cry of Freedom: The Civil War Era. New York: Oxford University Press, 1988.

Miller, William Lee. Arguing About Slavery: John Quincy Adams and the Great Battle in the United States Congress. New York: Vintage Books, 1995.

Morrison, Michael. Slavery and the American West: The Eclipse of Manifest Destiny and the Coming of the Civil War. Chapel Hill: University of North Carolina Press, 1997.

Neely, Jr., Mark E. The Boundaries of American Political Culture in the Civil War Era. Chapel Hill: University of North Carolina Press, 2005.

- "American Nationalism in the Image of Henry Clay: Abraham Lincoln's Eulogy on Clay in Context." Register of the Kentucky Historical Society 73 (January 1975). 
Nichols, Roy F. Franklin Pierce: Young Hickory of the Granite Hills. Philadelphia: University of Pennsylvania Press, 1931.

Noll, Mark A. America's God: From Jonathan Edwards to Abraham Lincoln. New York: Oxford University Press, 2002.

- The Civil War as a Theological Crisis. Chapel Hill: University of North Carolina Press, 2006.

Parker Edward G. The Golden Age of American Oratory. Boston: Whittemore, Niles \& Hall, 1857.

Parsons, Lynn Hudson. "The 'splendid Pageant': Observations on the Death of John Quincy Adams,” The New England Quarterly 53 (1980).

Pasley, Jeffrey L. "The Tyranny of Printers": Newspaper Politics and the Early American Republic. Charlottesville: University of Virginia Press, 2001.

Pasley, Jeffery L., Robertson, Andrew W., Waldstreicher, David. eds. Beyond the Founders: New Approaches to the Political History of the Early American Republic. Chapel Hill: University of North Carolina Press, 2004.

Paulus, Sarah Bischoff. "America's Long Eulogy for Compromise: Henry Clay and American Politics, 1854-1858," The Journal of the Civil War Era 4 (March 2014).

Perry, Lewis. Radical Abolitionists: Anarchy and the Government of God in Antislavery Thought. Ithaca: Cornell University Press, 1973.

Peterson, Merril D. The Great Triumvirate: Webster, Clay, and Calhoun. New York: Oxford University Press, 1987.

Potter, David M. The Impending Crisis 1848-1861. New York: Harper and Row, 1976. . "The Historian's Use of Nationalism and Vice Versa," American Historical Review 67 (1962), 924-950.

Purcell, Sarah J. "All That Remains of Henry Clay: Political Funerals and the Tour of Henry Clay's Corpse," Common-Place, 12, 2012. Accessed on 5/1/12.

Quigley, Paul. Shifting Grounds: Nationalism and the American South, 1848-1865. New York: Oxford University Press, 2014.

Remini, Robert V. Andrew Jackson. New York: Twayne Publishers, 1966. 
- Daniel Webster: The Man and His Time. New York: W.W. Norton and Company, 1997.

- Henry Clay: Statesman for the Union. New York: W.W. Norton \& Company, 1991.

Renda, Lex. "Retrospective Voting and the Presidential Election of 1844: The Texas Issue Revisited." Presidential Studies Quarterly 24 (1994).

Richard, Carl. The Founders and the Classics: Greece, Rome, and the American Enlightenment. Cambridge: Harvard University Press, 1994.

Richards, Leonard L. The Slave Power: The Free North and Southern Domination, 1780-1860. Baton Rouge: Louisiana State University Press, 2000.

Roberts-Miller, Patricia. Fanatical Schemes: Proslavery Rhetoric and the Tragedy of Consensus. Tuscaloosa: The University of Alabama Press, 2009.

Ross, Steven J. "The Transformation of Republican Ideology," Journal of the Early Republic 10 (1990).

Ryan, Mary P. Civic Wars: Democracy and Public Life in the American City during the Nineteenth Century. Berkeley: University of California Press, 1998.

Sandburg, Carl. Abraham Lincoln: The Prairie Years and the War Years One-Volume Edition. New York: Harcourt, Brace, and Company, 1954.

Schlesinger, Jr., Arthur M., ed. History of U.S. Political Parties. New York: Chelsea House Publishers, 1973. Volume I: 575-620.

Scott, Sean A. A Visitation from God: Northern Civilians Interpret the Civil War. New York: Oxford University Press, 2011.

Sewell, Richard. Ballots for Freedom: Antislavery Politics in the United States 18371860. New York: Oxford University Press, 1976.

Shafer Byron E., and Badger, Anthony J. eds., Contesting Democracy: Substance and Structure in American Political History, 1775-2000. Lawrence: University of Kansas Press, 2001.

Shelden, Rachel A. "Washington Brotherhood: Friendship, Politics, and the Coming of the Civil War," Ph.D. diss., University of Virginia, 2011.

Sinha, Manisha. The Counter-Revolution of Slavery: Politics and Ideology in Antebellum South Carolina. Chapel Hill: University of North Carolina Press, 2000. 
Snay, Mitchell. Gospel of Disunion: Religion and Separatism in the Antebellum South. Chapel Hill: University of North Carolina Press, 1997.

Stewart, James Brewer. Holy Warriors: The Abolitionists and American Slavery. New York: Hill and Wang, 1976.

- Joshua R. Giddings and the Tactics of Radical Politics. Cleveland: The Press of Case Western University, 1970.

Stout, Harry S. Upon the Alter of the Nation: A Moral History of the Civil War. New York: Viking Press, 2006.

Strong, Douglas M. Perfectionist Politics: Abolitionism and the Religious Tensions of American Democracy. Syracuse: Syracuse University Press, 1999.

Thompson, Alexander Ransay. A Tribute to the Memory of the Rev. George $W$. Bethune, D.D., Pastor of the Reformed Dutch Church, Twenty-First Street, NewYork. Cambridge: Harvard University Press, 1882.

Towers, Frank. "Partisans, New History, and Modernization: The Historiography of the Civil War's Causes, 1861-2011," The Journal of the Civil War Era 1, 2 (June 2011).

Turner, Henry Edward. The Greene's of Warwick in Colonial History: Read Before the Rhode Island Historical Society, February 27, 1877. Newport: Davis \& Pitman, 1877.

Unger, Harlow Giles. John Quincy Adams. Boston: Da Capo Press, 2012.

Varon, Elizabeth R. Disunion!: The Coming of the American Civil War. Chapel Hill: University of North Carolina Press, 2008.

Varon, Elizabeth R. We Mean to Be Counted: White Women and Politics in Antebellum Virginia. Chapel Hill: University of North Carolina Press, 1996.

Volk, Kyle G. “The Perils of 'Pure Democracy': Minority Rights, Liquor Politics, and Popular Sovereignty in Antebellum America," Journal of the Early Republic 29, 4 (Winter, 2009).

Voss-Hubbard, Mark. Beyond Party: Cultures of Antipartisanship in Northern Politics before the Civil War. Baltimore: Johnson Hopkins University Press, 2002.

Waldstreicher, David. In the Midst of Perpetual Fetes: The Making of American Nationalism, 1776-1820. Chapel Hill: University of North Carolina Press, 1997. 
Walters, Ronald G. The Antislavery Appeal, American Abolitionism After 1830. Baltimore: Johns Hopkins University Press, 1976.

Waugh, John C. On the Brink of Civil War: The Compromise of 1850 and How it Changed the Course of American History. Wilmington: Scholarly Resources, Inc., 2003.

Wheelan, Joseph. Mr. Adams's Last Crusade: John Quincy Adams's Extraordinary Post-Presidential Life in Congress. New York: Public Affairs, 2008.

Wilentz, Sean. The Rise of American Democracy: Jefferson to Lincoln. New York: W. W. Norton \& Company, 2005.

Wilson, Major, "Republicanism and the Idea of Party in the Jacksonian Period," Journal of the Early Republic 8 (1988).

Wineapple, Brenda. Hawthorne: A Life. New York: Random House, 2003.

Winterer, Caroline. The Culture of Classicism: Ancient Greece and Rome in American Intellectual Life 1780-1910. Baltimore: Johns Hopkins University Press, 2002.

Woods, Michael E. "What Twenty-First-Century Historians Have Said about the Causes of Disunion: A Civil War Sesquicentennial Review of Recent Literature," The Journal of American History 99 (September 2012).

. "The Heart of the Sectional Conflict: Emotion, Politics, and the Coming of the Civil War," Ph.D. diss., University of South Carolina, 2012. 